\title{
PERSISTENCE OF RACE
}

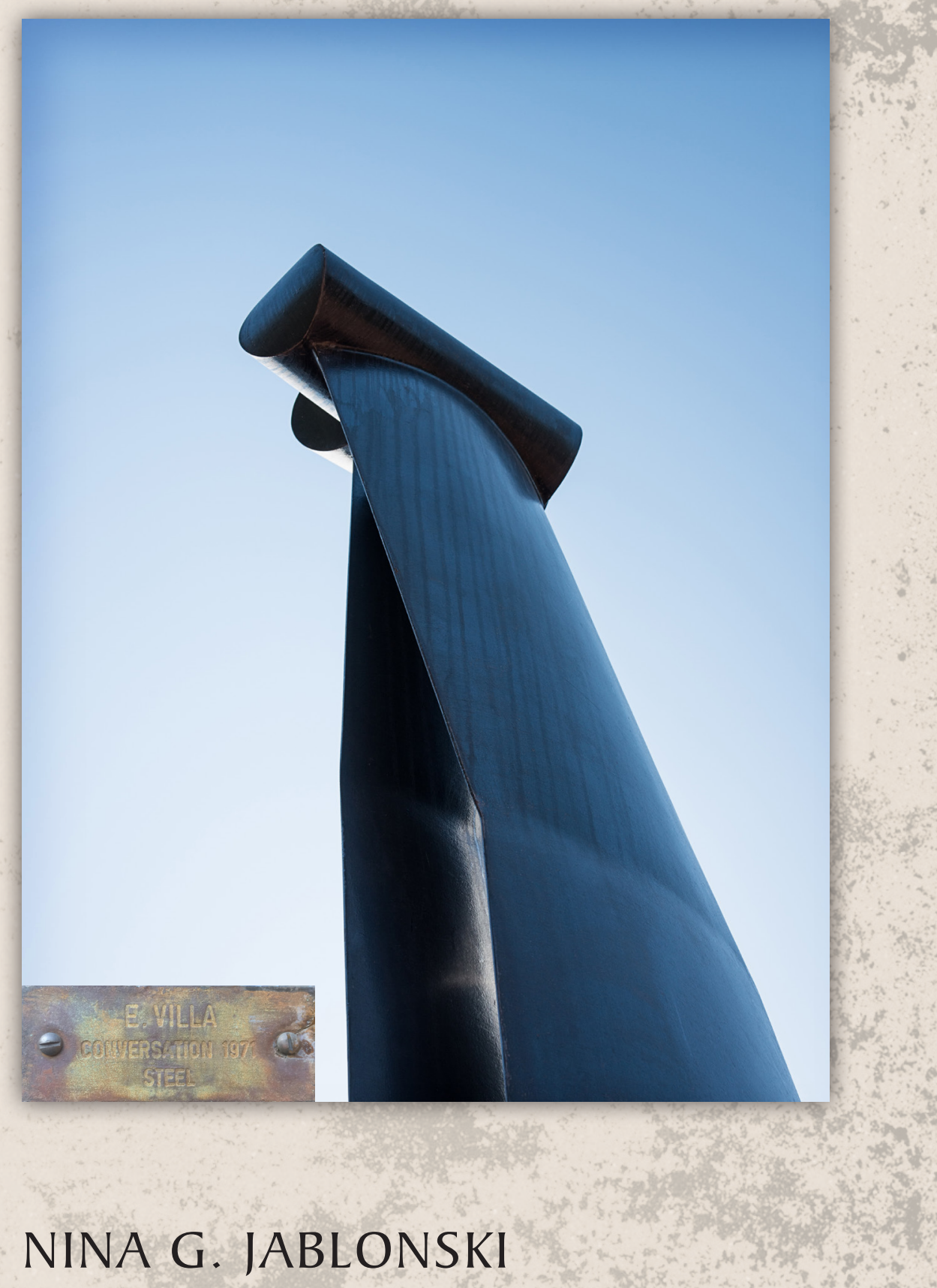

\author{
EDITOR
}




\section{PERSISTENCE OF RACE

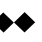

EDITOR

NINA G. IABLONSKI

${ }_{\bar{\omega}}^{2} \mathrm{PROSS}$ 


\section{Persistence of Race}

Published by African Sun Media under the SUN PReSS imprint

All rights reserved

\section{Copyright (c) 2020 African Sun Media and STIAS}

This publication was subjected to an independent double-blind peer evaluation by the publisher.

The authors and the publisher have made every effort to obtain permission for and acknowledge the use of copyrighted material. Refer all enquiries to the publisher.

No part of this book may be reproduced or transmitted in any form or by any electronic, photographic or mechanical means, including photocopying and recording on record, tape or laser disk, on microfilm, via the Internet, by e-mail, or by any other information storage and retrieval system, without prior written permission by the publisher.

Views reflected in this publication are not necessarily those of the publisher.

First edition 2019

ISBN 978-1-928480-44-0

ISBN 978-1-928480-45-7 (e-book)

https://doi.org/10.18820/9781928480457

Set in Arno Pro 12/14

Cover design, typesetting and production by African Sun Media

Cover image: Edoardo Villa (1915-2011) steel sculpture Conversation (1971), located at School of Mechanical Engineering building, Howard College campus, University of KwaZulu-Natal. (Photographer (c) Andrew Griffins)

SUN PReSS is an imprint of African Sun Media. Scholarly, professional and reference works are published under this imprint in print and electronic formats.

This publication can be ordered from:

orders@africansunmedia.co.za

Takealot: bit.ly/2monsfl

Google Books: bit.ly/2k1Uilm

africansunmedia.store.it.si (e-books)

Amazon Kindle: amzn.to/2ktL.pkL

Visit africansunmedia.co.za for more information. 


\section{The STIAS series}

The Stellenbosch Institute for Advanced Study (STIAS) was born from a simple but powerful conviction: in this part of the world special initiatives are required to create and maintain an environment where we can generate and engage with conceptual frameworks and knowledge that may guide us in tracking and co-shaping global academic developments and that will allow us to address the 'big' questions and issues South Africa and the African continent face, also in a global context.

STIAS has been moulded in the tradition of Institutes for Advanced Study across the globe. It distinguished itself by encompassing all disciplines from the natural to the social sciences and humanities (with a particular emphasis on research grounded in multi-disciplinarity), by maintaining a focus on the African and South African context, and by striving towards contemporary relevance, also by actively creating avenues for communicating the results of its research projects to a wider public.

The STIAS series publications, of which this is the fifteenth volume, are thus aimed at a broad public which will naturally vary with specific research themes. Straddling the academic world and the forum of an engaging public is a challenge that STIAS accepts; we trust that each STIAS publication reflects the 'creative space for the mind' in which it is rooted, stimulates public interest and debate, and contributes to informed decision making at various levels of our society.

Further information about STIAS and its research programme may be found at www.stias.ac.za.

Edward Kirumira STIAS Director

Stellenbosch

November 2019

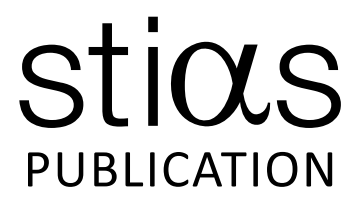




\section{CONTENTS}

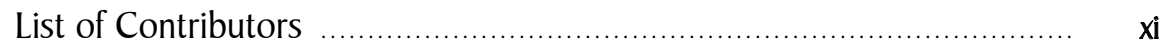

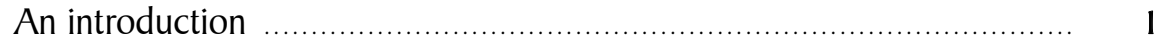

Nina G. Jablonski

\section{HOW THE STAGE WAS SET}

I Racism's workshop: Explaining prejudice and hate …......................... II Crain Soudien

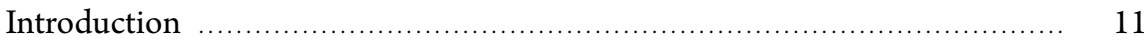

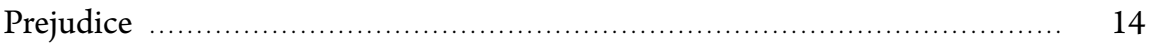

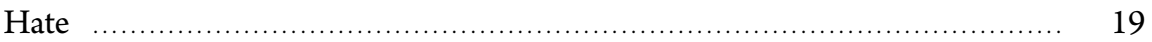

Some issues: How do prejudice and hate work?

Do they work differently? ........................................................... 22

A way forward: Between prejudice and hate ………….......................... 24

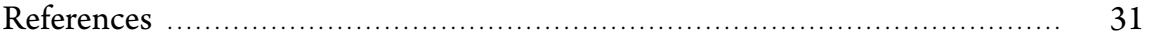

2 An unlikely turning point: Skin bleaching and the growth of colourism in South Africa

Nina G. Jablonski

Skin lightening in historical context

The commercial development of skin lighteners in the United States

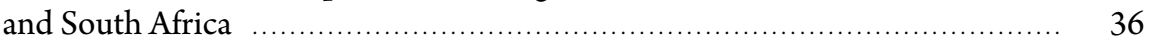

The rise of skin bleaching in South Africa .......................................... 36

Conclusion: The introduction of skin bleaches into South Africa

was a genuine turning point …….................................................. 39

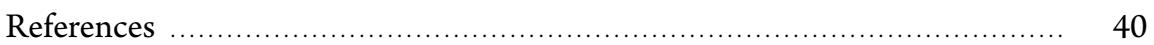

3 Settler-colonialism, nationalism and geopolitical politics:

An overview of the mobilisation of race in South Africa

in the context of lost turning points

George Chaplin

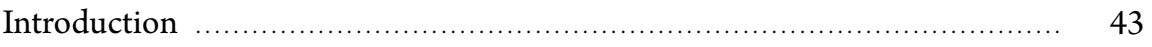

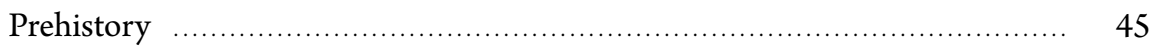

South Africa's strategic position …….............................................. 45

Race, racialism and racism in settler, colonial or nationalist South Africa ....... 46

The first encounter with mercantile Europeans …................................. 47

Early ideas were not embedded in race, but in terms of religion, monetary worth and location ......................................................... 48

Dutch identity emerges in reaction to British economic colonialism …........ $\quad 49$

Modern imperialistic capitalism and colonialism ………...................... 51

Dutch settlers cement the concept of Afrikaners ……............................. 51 
The British seek to crush emerging Afrikaner identity ....................... 52

Complex interplay between groups of the South African population $\ldots . . \ldots \ldots \ldots . \quad 54$

Anti-British elements seek theories and allies on the global stage ............... 54

Early communism ......................................................... 55

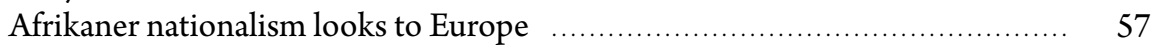

Post-World War I social experiments in Europe .............................. 57

The British colonialist attitude after the start of decolonialism ................. 64

Indigenous people respond to nationalist provocation $\ldots \ldots \ldots \ldots \ldots \ldots \ldots \ldots \ldots . \ldots 5$

Multicultural support for more equal treatment moves to the left ............. 65

Communism amongst African indigenous groups $\ldots \ldots \ldots \ldots \ldots \ldots \ldots \ldots \ldots \ldots . \ldots \ldots 6 . \ldots \ldots$

International response to perceived communist threat $\ldots \ldots \ldots \ldots \ldots \ldots \ldots \ldots \ldots . \ldots 6$

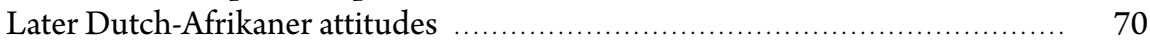

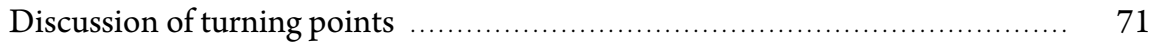

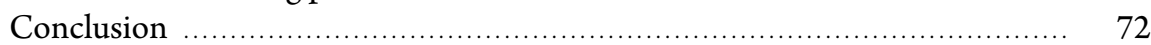

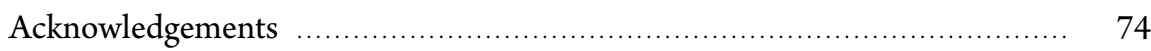

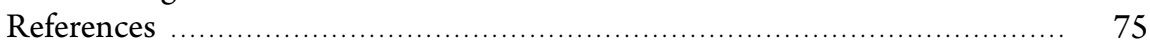

$4 \quad$ From settler to postcolonial: The turn of the South African

nation-state in a comparative perspective ................................ 79

Göran Therborn

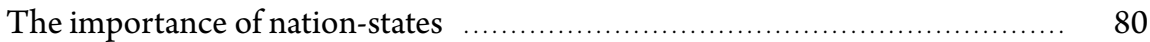

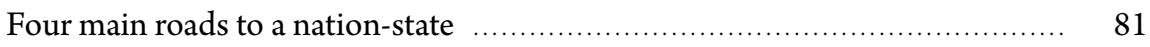

South Africa as a settler-state ............................................. 81

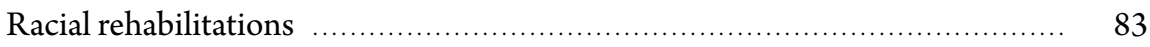

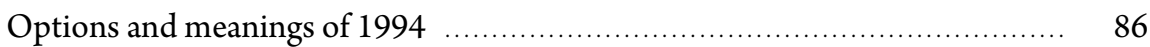

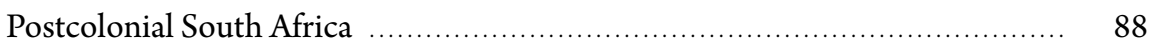

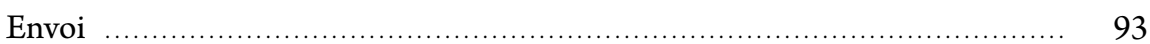

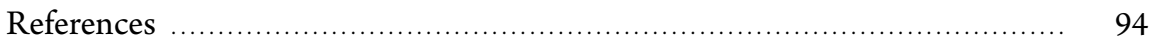

\section{ASSESSMENT AND FUTURE PROSPECTS}

5 Ways of being: "Race" as common sense;

non-racialism as humanist necessity f...................................... 99

Gerhard Maré

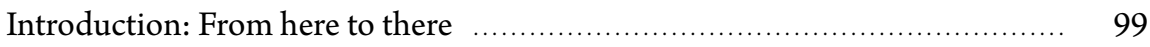

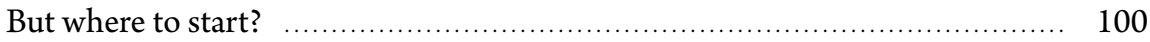

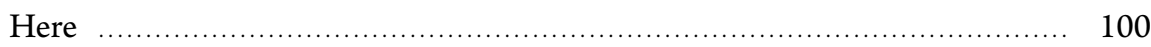

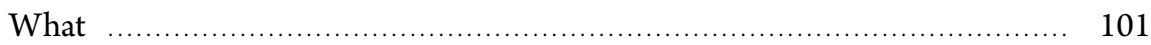

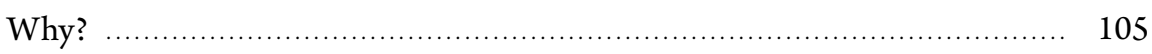

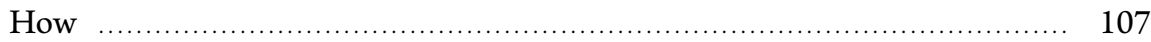

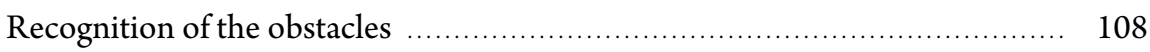

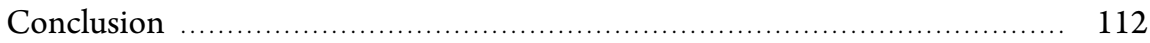

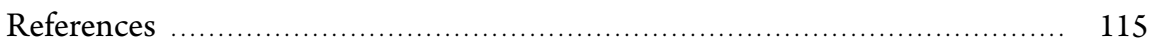


6 The effects of racism on the human body

Nina G. Jablonski

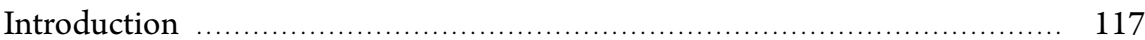

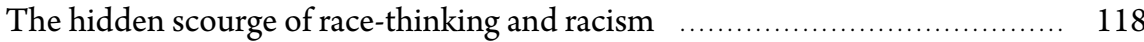

The lasting effects of stress caused by racism ..................................... 119

Epigenetic information does not mean "no hope" ................................ 121

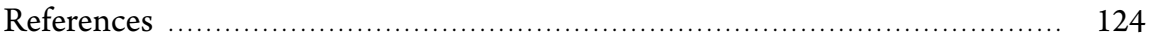

$7 \quad$ Knowing and being: Living our learning about "race" ..................... 127

Crain Soudien

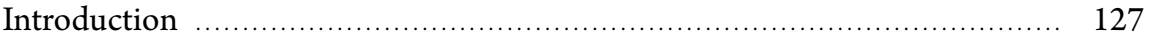

So what do we know about "race"? .................................................. 130

Classification: The power of normative orders versus

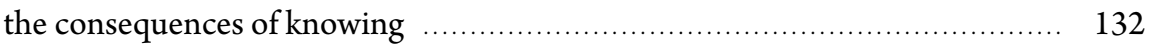

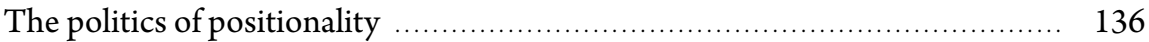

Concluding thoughts: How would ethical thinking be brought about? ......... 139

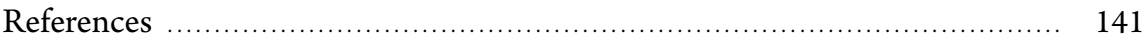

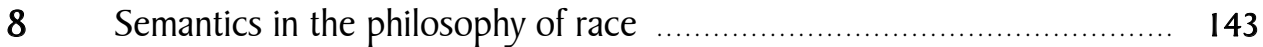

George Chaplin and Nina G. Jablonski

The three questions: The problem of racial thinking ……....................... 143

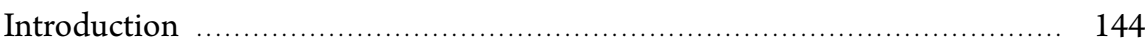

Race labels and hate speech ......................................................... 145

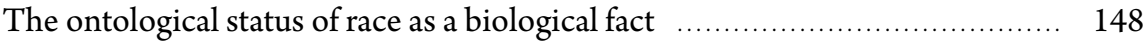

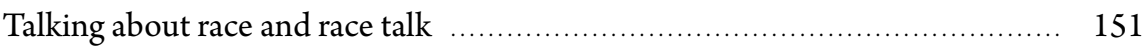

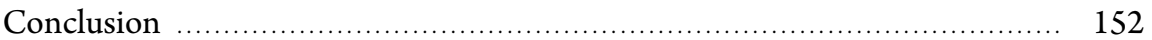

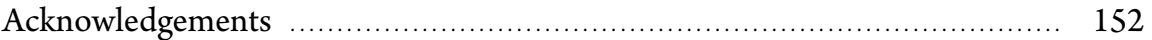

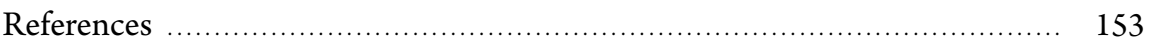

$9 \quad$ "Who was here first?", or "Who lives here now?":

Indigeneity, a difference like no other ......................................... 155

Zimitri Erasmus

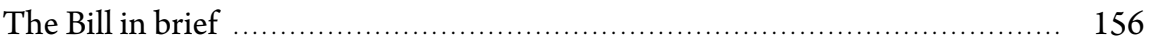

The Reports: Producing a difference like no other ……....................... 158

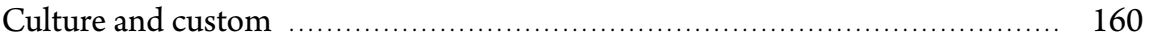

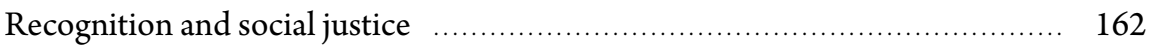

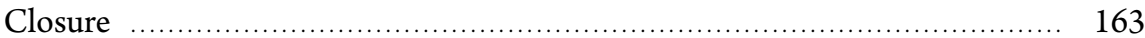

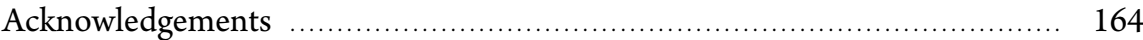

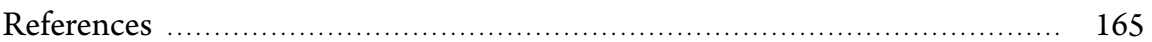


10 South Africa beyond "non-racialism"

Njabulo S. Ndebele

I

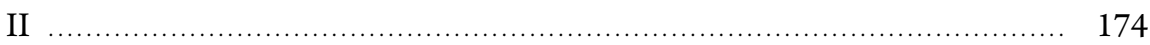

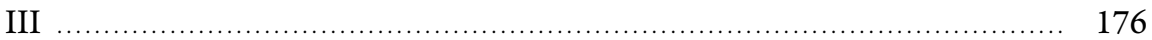

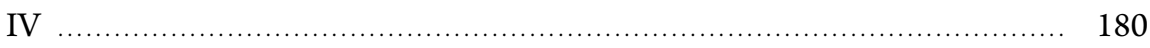

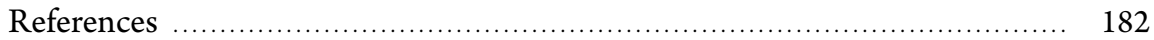




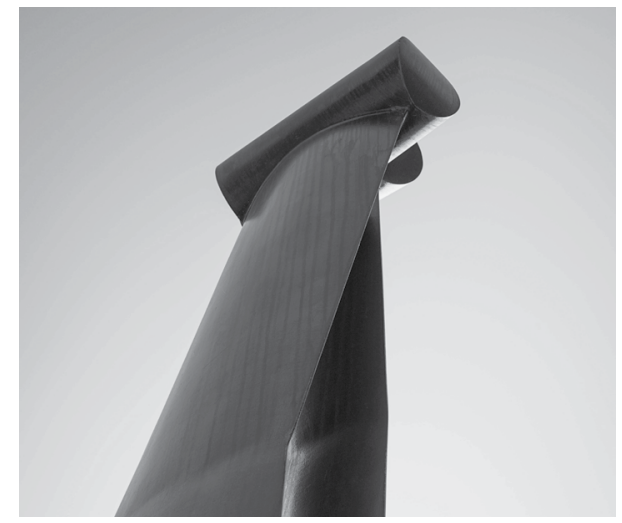

\section{LIST OF CONTRIBUTORS}

George Chaplin is a Senior Research Associate in the Department of Anthropology at The Pennsylvania State University. He conducts research on the evolution of skin color and the history of race and racism. [orcid: 0000-0002-7341-7742]

Zimitri Erasmus is Associate Professor of Sociology (in Anthropology) at the University of the Witwatersrand. Her book, Race Otherwise: Forging a New Humanism for South Africa (University of Witwatersrand, 2017), conceptualises the boundaries between racial identities as thresholds to be crossed through politically charged acts of imagination and love. [orcid: 0000-0003-1528-0992]

Nina G. Jablonski is the Evan Pugh University Professor of Anthropology at The Pennsylvania State University and Fellow of STIAS. She studies the evolution of human physical diversity and the meanings associated with human physical appearance. [orcid: 0000-0001-7644-874X]

Gerhard Maré is Professor Emeritus at the University of KwaZulu-Natal. He is the author of Declassified: moving beyond the dead end of race in South Africa (Jacana, 2014). [orcid: 0000-0003-0937-1871] 
Njabulo S. Ndebele is Emeritus Professor at the University of Cape Town, an author of fiction and essays, Fellow of STIAS, and Chancellor of the University of Johannesburg. [orcid: 0000-0002-6863-9332]

Crain Soudien is the CEO of the Human Sciences Research Council. He is a scholar of social difference and inequality. [orcid: 0000-0002-9934-6532]

Göran Therborn is Professor Emeritus of Sociology at the University of Cambridge, UK, and is now living in Sweden. His current work is focused on inequality, power and social movements, and the politics of cities. His book, Inequality and the Labyrinths of Democracy, will be published by Verso in the second half of 2020 . 


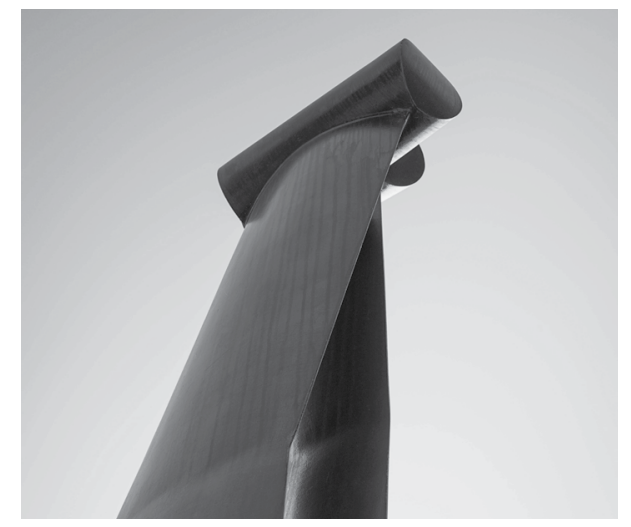

\title{
AN INTRODUCTION
}

\author{
Nina G. Jablonski
}

In this volume, we are happy to present the third and final group of essays emerging from the discussions of the Effects of Race (EoR) Project at the Stellenbosch Institute for Advanced Study (STIAS) that occurred in 2016 and 2017. The EoR Project is part of the "Being Human Today" initiative, one of the longer-term theme projects sponsored by STIAS since 2013. The primary goal of the EoR Project was the development of new scholarly research bearing on the disturbing continuation of race-thinking and racism, and of antagonism towards fellow human beings caused by racism. The EoR Project sought to address the roots of the "everydayness of race" in South Africa and elsewhere by exploring widespread misconceptions about visible and cultural human diversity, the linguistic infrastructure of racialism, and the complexity of multiple identities. The contributors to the EoR Project have, over the years, wrestled with the question of how race ideologies have become tradition and "common sense", and are no longer recognised as self-conscious belief systems (Swidler, 1986). They have recognised that the "everydayness of race", when viewed from a structuralist perspective, is best understood as a set of 
assumptions about the nature of the world that has become so unselfconscious as to seem a natural, transparent, and undeniable (Geertz, 1975; Swidler, 1986). If the contributors to the EoR Project and this volume had any single goal, it could be best expressed as achieving further understanding of the complex and perfidious assumptions surrounding race and race-thinking so as to further dismantle the belief in race as common sense.

Meetings of the EoR Project took place at STIAS from 2014 through 2017, and involved a diverse body of scholars, thinkers, and educators from different constituencies in South Africa along with several scholars from Europe and the United States. As described in the introduction to The Effects of Race (Jablonski, 2018), the "core group" comprised a group of well-established senior scholars who engaged in theme-oriented discussions, and the "projects group" of mostly younger South African scholars and educators involved in specific, goal-oriented projects. This volume represents contributions developed from the discussions at EoR core group meetings held at STIAS in July 2016 and July 2017. The members of the EoR core group present at STIAS in 2016 were, in alphabetical order: George Chaplin, Zimitri Erasmus, Nina Jablonski, Gerhard Maré, Njabulo Ndebele, Barney Pityana, Crain Soudien and Göran Therborn. Those present in 2017 were: Zimitri Erasmus, Nina Jablonski, Gerhard Maré, Njabulo Ndebele, Barney Pityana, Crain Soudien and Göran Therborn.

Prior to meeting each year, core group members decided together on a theme that would provide focus to their discussions. In 2016, the theme was "Turning points in the history of race and racism in South Africa" and, in 2017, the theme included three conjoined questions, "What do you wish to change with regard to race, racism and racialism?", "Why?" and "How would you bring this about?" These were big themes, and core group members conceived of them and developed them according to their own intellectual backgrounds and personal experiences. In both years, preliminary discussions focused on clarifying the topic at hand. In 2016, for instance, discussions opened with a fruitful exchange about different members' conceptions of what was meant by a "turning point". These were not sterile or hairsplitting discussions of semantic points; they were conversations that warmed up group members to engage with one another's thought processes and reintroduced them to the nature and complexity of the topics at hand.

The dynamics of the core group meetings held at STIAS bear importantly on this volume and on the totality of the EoR Project. During meetings, core group members trusted and respected one another, and recognised that each person brought a valued body of learning and experience to the group. This mutual trust and respect made it possible for group discussions to develop naturally and without rancour, and mostly without defensiveness of individual intellectual territories. 
This made for an extraordinarily constructive and elevating atmosphere, even when the most sensitive and difficult topics were being considered. The spirit and nature of the discussions were aptly summed up by Njabulo Ndebele in conversation at the end of the 2016 session, "The elephant is in the room and we are petting it". The 2016 and 2017 discussions revealed the deep thoughtfulness of core group members and their willingness to listen carefully to one another and explore bodies of knowledge with which they had little familiarity previously. The psychological flexibility and learning abilities revealed were impressive and heartening, and conduced to a higher level of sophistication and integration of thinking about race than we had previously achieved. The whole was much more than the sum of its parts.

This volume is divided into two sections, which roughly map the group's 2016 and 2017 discussions, respectively. In the first section, "How the Stage Was Set", the authors explore some of the reasons why the concepts and practices of race, race-thinking, and racism continued to exist and be reinvented in South Africa and elsewhere in the face of legislation and scientific knowledge. Taking inspiration from the theme of turning points, the authors refer in their chapters to local or global events or movements which influenced these processes in South Africa. The contributions reflect clearly too the diverse intellectual backgrounds and professional training of the authors. Here we see phenomena examined through the lenses of many disciplines: sociology, history, geography, anthropology, and writing.

Crain Soudien sets a courageous and sobering tone for the section and the volume in the first chapter, "Racism's workshop: Explaining prejudice and hate". $\mathrm{He}$ explores the cognitive dimensions of racism, prejudice and hate, examining how these attributes are acquired and become part of the consciousness of individuals and groups. The turning point which catalyses Soudien's investigation is the conclusive amassing of scientific evidence demonstrating the non-existence of human races. Why should prejudice and hate persist when the reasons for their existence have been eliminated? What Soudien thus excavates in this chapter are the reasons and mechanisms for the development and persistence of prejudice and hate in the absence of "evidence". His chapter not only explores the phenomenology of the transmission of negative emotions through seemingly trivial expressions and gestures, but also how social scientists over the last half-century have sought to interpret this troubling phenomenon. This chapter addresses and effectively dismisses the contention of many sociobiologists, including Van den Berghe, that race is best understood as a manifestation of preferential kin selection, advantageous in the evolutionary process (Van den Berghe, 1987). 
In the next chapter, "An unlikely turning point: Skin bleaching and the growth of colourism in South Africa”, Nina Jablonski considers how racism and negative attitudes towards dark skin colour, especially during the apartheid era, propelled the development and use of skin lighteners in South Africa from the mid-twentieth century onward. Jablonski shows that one of the ways in which some South Africans responded to crises of identity during apartheid was by attempting to change their personal appearance. Because skin colour was the most physically obvious manifestation of difference, and because preferences for light skin were blatant, skin lightening became extremely popular in South Africa when products were introduced and widely manufactured in the country beginning in the 1950s. Jablonski shows that skin lightening remains popular since the end of apartheid because preferences for lighter skin remain and the psychosocial pressures to lighten the skin are felt by many.

The next two chapters, by George Chaplin and Göran Therborn, respectively examine the social, racial and political landscapes of South Africa during its long period as a settler-colonial state. In his chapter, "Settler-colonialism, nationalism and geopolitical politics: An overview of the mobilisation of race in South Africa in the context of lost turning points", Chaplin examines how attitudes and policies towards race in South Africa and official South African government positions on race during the late nineteenth and twentieth centuries were influenced by social and political movements outside of South Africa. Most historical and sociological treatments of South African race policies during this time emphasise that South Africa's policies developed sui generis, and did not draw inspiration or direction explicitly from movements outside of South Africa. Chaplin disagrees, and in an expansive historical overview dissects the influences of global geopolitics on the development of nationalist movements in South Africa, from early Russian communism to Nazism to later Soviet communism. His detailed exegesis provides detailed evidence for the influence of these contrasting powerful ideologies on the political and governmental landscape of South Africa. Of greatest importance is his description of the rise of influence of Nazi ideology on the development of the philosophical underpinning and racialised mechanisms of the South African apartheid state. The eventual triumph of Nazi philosophy in South Africa in everything but the name was and remains a source of shame and denial even in academic circles in the country. Chaplin's reference to a lost turning point in his title makes fascinating use of an engaging counterfactual scenario from mid- and late twentieth century history. He ponders if the course of apartheid might have been shortened if those opposing it had not embraced Soviet communism, and whether racial justice in South Africa may have been better served and apartheid reversed if American and European democracies had not feared the communists they saw lurking behind African nationalism. 
In the next chapter, "From settler to postcolonial: The turn of the South African nation-state in a comparative perspective", Therborn looks at the twentieth-century history of South Africa in the context of other nation-states and grounds South Africa in the context of global colonialism. His focus is on how the establishment of a new democratic government in 1994 marked a turnaround in the ideological underpinnings of the country, if not entirely in its economic fortunes. Therborn's chapter draws considerably on his highly regarded overviews of the diverse origins of nation-states. As a settler-state, South Africa was inherently racist by definition, but it developed a uniquely repressive manifestation of settler-statehood because of its unusual demography, with white Europeans accounting for only $20 \%$ of its population. Examining its "racial rehabilitation" in the context of other settlerstates, he notes that South Africa's rejection of apartheid was part of a global movement of human equalisation, which included rejection of institutionalised racism and sexism. He shows how the abolition of apartheid in 1994 in South Africa meant the abolition of the settler-state itself and all the mechanisms of social repression that went with it. This did not, however, bring an immediate turnaround in the fortunes of the country or its once-repressed populations. Although much has been done to address the many severe manifestations of inequality in South Africa, the country remains markedly unequal because, Therborn argues, it was so from its earliest days as a settler-state before apartheid.

The volume's second section, "Assessment and Future Prospects", is devoted to chapters expressing some of the deepest of the EoR core group's discussions about the costs of a racialised world order to humans and humanity. These sprang from the group's exploration of "the three questions" in 2017: "What do you wish to change with regard to race, racism and racialism?", "Why?" and "How would you bring this about?" The topics which emerged from consideration of these questions were close to the hearts of core group members, and reflected individual interests and predilections as well as the influence of current events such as the \#RhodesMustFall movement. The group's discussions and members' essays did not express clear solutions to profound problems, but rather developed into deeply thoughtful foundations for detailed explorations into South African racial politics and the long-term effects of race in South Africa and elsewhere. The discussions and essays were predictably diverse, and included investigation of the South African Constitution and specifically, how contemporary politics and social values failed to fulfil the promises of social equality enshrined in the document. They also considered the biological and social understandings of race, and how new information from both the biological and social sciences was changing our perspective on the nature of the human condition, including the association of biological and social phenomena with "race". Finally, the discussions and essays explored how race-thinking framed the very nature of human beings and the human 
condition, including the ways we express ourselves and relate to one another through language. The six chapters in this section comprise distinct forays into the realities of race-thinking and their pervasive and sinister effects on the human being and human societies.

In the first chapter of this section, Gerhard Maré revisits the most salient theme of his oeuvre in, "Ways of being: 'Race' as common sense; non-racialism as humanist necessity”. Maré's chapter is a conversation with himself and the reader in which he poses questions about race and race-thinking at all phenomenological levels. This is an uncomfortable conversation about the nature of the verities of racethinking and how every manifestation of race-thinking and racialism - whether it touches on biology, language, human rights, or the greater social order - is about recognition of inherent difference. The scourge and the tyranny of race, he argues, is that it deforms the substrate of thinking about everything else. Maré is cautiously optimistic about the future and challenges current and future generations to determine their own moral compass and to not be directed by social constructions of the past.

In the next chapter, Nina Jablonski discusses "The effects of racism on the human body", an exploration into the nature and kinds of biological damage done to the body by long-term racism. This chapter does not explore "racial differences" in biology, but differences in biology brought about by racism. The chapter peels away the layers of effects of racism and discrimination on human health. Effects on socioeconomic position mature during human lifetimes into adverse effects on well-being through health disparities at multiple levels. Jablonski's rumination on the unrecognised toll of epigenetic modifications to the human body caused by the stresses of racism raises new sets of worries about the costs of racism, as we begin to recognise the many ways in which human bodies and human genes are being constantly remodelled by the physical and social environment and by life experience.

Crain Soudien, in the next chapter, "Knowing and being: Living our learning about 'race", develops one of his deepest discussions to date on the nature of what we might call "race knowledges" and how they affect our being and state of knowing. Like Marés chapter, Soudien's is a personal reflection based on a life of observation and experience about and with race-thinking and recognition of the humanitarian consequences of a racialised world. This chapter is a search into the nature of the kinds of knowledge that exist about race and how we as individuals metabolise those knowledges. The discussion of how inequality changes the fabric of any relationship is insightful and, here, Soudien places the burden on the knower, the person aware of the effects of their status on life's outcomes. His prescription for the future - that we should have consciousness of regard for all human beings and 
know others as we know ourselves - is not new, but the path he takes to reach the conclusion is, and makes for, a highly salutary read.

The following chapter, "Semantics in the philosophy of race" by George Chaplin and Nina Jablonski, examines another aspect of race knowledges by looking at the extent to which race-thinking has co-opted our consciousness and language. Chaplin and Jablonski contend the fossilised lexicon associated with race has made any attempt to deal with the effects of racism almost impossible. The solution they advance is the creation of a new, non-pejorative vocabulary for defeating race that is acceptable to all. The authors' discussion is unique in that they incorporate into their discussion a philosophical repudiation of race as a biological concept applicable to humans. The fact that human races have no metaphysical reality, they argue, is the ultimate negation of race-thinking. That our current depauperate lexicon prevents us from describing this properly and abolishing racism is a tragedy, but hope arises, the authors contend, from a willingness to create a new way of thinking, conceiving, and verbalising about humanity.

Zimitri Erasmus, in the next chapter, "Who was here first?', or 'Who lives here now?': Indigeneity, a difference like no other", looks at race knowledges from a related perspective, but arguing from different evidence. She explodes the overused simplification of race being just a social construct by looking closely at "race" as composed of interconnected and institutionalised practices of power in relation to class, gender and multiple other factors. These practices are specific to historical moments and together they shape the racialised realities of any place and time. Erasmus' discussion focuses specifically on the status of people who self-identify as "Khoi-San", and their status as the original indigenous people of South Africa. She critically examines the nature and application of the concept of indigeneity as it has been applied to the Khoi-San, and especially as it has been used recently to differentiate them from other non-European South Africans and accord them special privileges. Erasmus' treatment exposes the ultimately contingent nature of race and the practice of race labelling, and questions the value of labels such as "indigenous" especially when they are applied as sops without substance.

Njabulo Ndebele ends this section and the volume with his provocative chapter, "South Africa beyond 'non-racialism'". Here, Ndebele looks beyond the damage wrought to individuals and societies by race and racialised conceptions of the human condition to examine the real costs of these phenomena to the world, as they have played out over centuries. After counting the horrific worldwide humanitarian and economic costs of racism, he does not dwell in bitterness or pessimism, however. He sees a bright future and, in South Africa in particular, a new human order grounded in a "majoritarian human norm that carries the motive responsibility to create a new and humane future for all”. 
In the diversity of its chapters and their respective authors, we have in this volume a unified loud voice, arcing towards a world without race, race-thinking and racism. This is the voice that calls out the many origins of injustice that people have meted out to one another and experienced as the result of a racialised world order. The chapters in this volume were born out of the unity of humanity that was experienced during the STIAS meetings of the EoR Project, and it is the hope of all the contributors that this loud and strong voice will be heard. With persistent effort, race will be transformed from common sense to nonsense.

\section{References}

Geertz, C. 1975. Common sense as a cultural system. The Antioch Review, 33(1):5-26. https://doi.org/10.2307/4637616

Jablonski, N.G. 2018. An introduction. In: N.G. Jablonski \& G. Maré (eds.). The Effects of Race. Stellenbosch: African Sun Media.
Swidler, A. 1986. Culture in action: Symbols and strategies. American Sociological Review, 51(2):273-286. https://doi. org/10.2307/2095521

Van den Berghe, P.L. 1987. The Ethnic Phenomenon. New York: Praeger. 


\section{SECTION I}

\section{HOW THE STAGE}

WAS SET

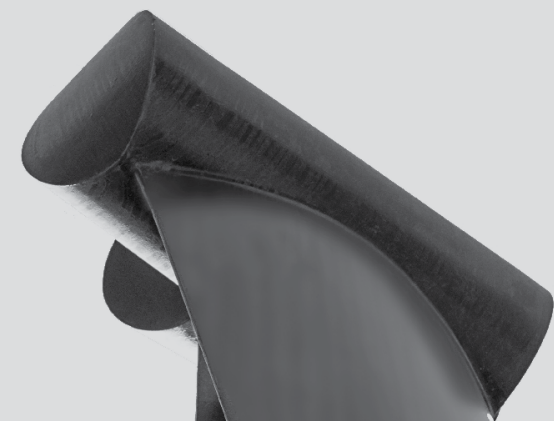




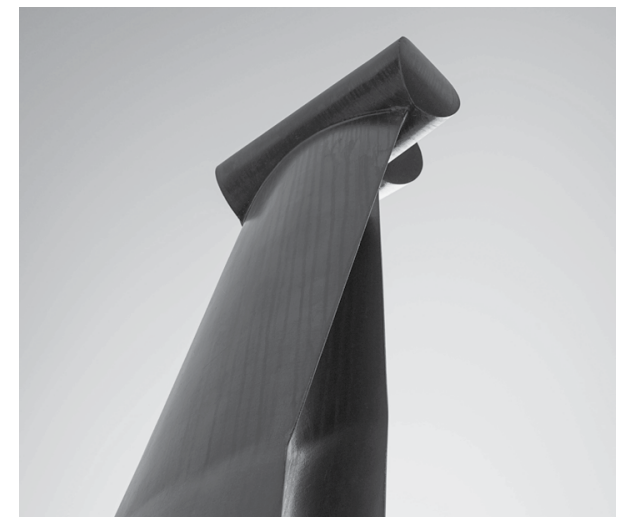

\title{
RACISM'S WORKSHOP \\ Explaining prejudice and hate
}

\author{
Crain Soudien
}

\section{Introduction}

The relationship between prejudice, hate and racism has an extensive and complex literature (see Davidio, Hewstone, Glick \& Esses, 2010). The discussion, however, suffers, as Royzman, McCauley and Rozin (2005:27) suggest, from a kind of circularity. Much of it is self-validating. It uses examples of phenomena such as prejudice and hate to explain and account for what these phenomena actually are. This chapter is motivated by the urgency to understand them better. Situated in a larger project which seeks to explain how racism works as a process of reasoning - its psychosocial complexity and particularly its emplacement inside and astride the social and the psychological. The project has as its focus the individual mind, not as it functions as an autonomous psychological organism, but as it interacts with the larger social context in which it is located. At the core of the project is an interest in the cognitive dimensions of racism, prejudice and hate. How are they acquired? How do they become part of the consciousness of individuals and groups? 
The immediate motivation for this work comes, it needs to be made clear, from an apparent upsurge in South Africa, and, indeed, in many other parts of the world, of hate-speech and hate-crimes motivated by racism and the need, in the moment, to respond to these events. As observers of hate crimes in South Africa, the South African Hate Crime Working Group note, while

[t] here are no official statistics on the number of cases of hate crimes, ... human rights groups have documented a disturbing pattern of violent attacks, ranging from race-related attacks and targeted mob violence in residential and commercial districts occupied by foreign nationals, to severe beatings of LGBTI individuals and 'corrective' rapes and murders of lesbians ... . What has been documented is likely only the tip of the iceberg as it is widely believed that many incidents - particularly lower level violence and harassment - go unreported ... $\quad$ (South African Hate Crime Working Group, c.2012:3) ${ }^{1}$

Supplementing this observation are the results of the Institute for Justice and Reconciliation's 2015 Barometer Survey (Hofmeyr \& Govender, 2015:11) which shows that while more than a third $(35,6 \%)$ of the respondents surveyed reported that they had not experienced any form of racism, 11,9\% said that they experienced racism all the time. There is, however, a more fundamental concern. This concern has to do with the knowledge base of that which supposedly lies behind many of the most heinous murders that have taken place around the world and especially in South Africa - the knowledge of "race". While there continues to be a group of scientists (see Edwards, 2003; Dawkins \& Wong, 2005) who insist that the idea of "race" is real biologically, the consensus scientifically is that the process involved in the mapping of the human genome has revealed nature's "real world of irremediably diverse individuality ... Nature's world of diverse individuality illustrate(s) that the concept of race has no genetic or scientific basis; and that there is no way to tell one ethnicity from another in the five Celera genomes" (Fields \& Fields, 2014:6-8). This consensus denotes a turning point. In terms of what science currently knows, it is not possible to distinguish "race", yet, in the minds of many it can be done. It can be done, and, what is more, sufficiently clearly that they will kill for it. It is how this falsehood works in the everyday mental logics of its custodians that requires urgent analysis. The "turn" has not yet happened for them, or, it has, and this requires a great deal more analysis, as the case of Barend Strydom explored in this chapter suggests, precipitated in individuals with deeply ingrained ideas of their superiority, race, gender, nationality, and more profound experiences of disorientation. Extreme violence is for them, then, the only way to "correct" the social order.

1 See also the website www.lovenothate.org.za 
In relation to this disjuncture, the question holding the larger enquiry and motivating the study is: Do we know enough about how the idea of "race" lives on and why it constitutes such an extraordinary site of self- and group-capture? Do we understand its compulsions, the feints and parries, subterfuges, deceptions, dishonesties, falsities, and superficialities it harbours within itself?

Towards getting at these issues - the paradox inside the turn the world is experiencing - the chapter raises the issue of what takes place between the social and the psychological, and specifically that which Krysan (2000:154) has described as the "imbalance" in the psycho-social discussion - the dominance of the cognitive and the neglect of issues of affect. I am interested in affect broadly, but my focus in this chapter on the form of hate. I do so, as suggested above, against the apparent persistence around the world, and pointedly in countries such as South Africa and the United States, of deep, egregious, and sometimes violent forms of social discrimination, often with racial, gender and religious features. It is in response to the latter, as part of my own interest in the relationship between reason and affect, or the emotional and the political, or, more prosaically, the heart and the head, that I have chosen to focus on the emotion of hate. To understand hate better, there is a need to return to the foundational understandings that exist around prejudice, hate, and their related syndromes. There is need for refreshing the analytic tools and discursive frameworks that are available for understanding contemporary racism.

The chapter begins with a review of what we know about prejudice and hate in psychological terms. The research base for hate, it needs to be said, especially forms of hate in relation to racism and sexism, is distinctly smaller, less empirical, and less theoretical than that for prejudice. While hate is often subsumed within explanations of prejudice, largely correctly so, there is need to show how it can be distinguished from other forms of prejudice and how, in this distinction, it works. With this understanding, the chapter begins with an exploration of prejudice, what it means and how it is related to hate. It then draws out the major debates around hate, what it is and what it includes and excludes. In the conclusion, the chapter looks at the case of the South African white supremacist, Barend Strydom, who murdered eight black people in 1988. The judge who found him guilty cited hate as a factor in the perpetration of the murders. The purpose behind the exercise is to make better sense of what is meant when hate is invoked alongside of and in the process of discriminating, in whatever form, against another person or group. How does it relate to prejudice and what does it depend on; moreover, what does it recruit and mobilise in the process of taking position in relation to another person or group? I raise these questions because, one can argue, both its meaning and how it works, are loose propositions which are yoked into service behind explanations of phenomena, such as racism and sexism, in frequently unedifying kinds of ways. As propositions they perform all kinds of functions. 


\section{Prejudice}

Prejudice, building on the work of Gordon Allport (1954; 1979) and Thomas Pettigrew (1959), has a strong literature based on a relatively strong research and empirical record of research into discrimination. While, as Jacobs and Potter (1998:par. 5) have pointed out, "sociologists and social psychologists have long wrestled with the concept of prejudice, (and) have been unable to agree on a single definition", the work of Allport (1954), Pettigrew (1959) and Aboud (1988) has anchored the different approaches scholars have taken to the discussion. There is a reasonable consensus that prejudice is a negative attitude towards individuals and groups based solely on their membership of a group to which is attributed certain characteristics. Aboud's (1988:6) extension of this is that prejudice is a "unified, stable, and consistent tendency to respond in a negative way towards members of a particular ethnic group".

Allport's (1954) five level model of prejudice, lain out in his foundational work, The Nature of Prejudice, remains one of the most useful texts for understanding the ways in which human beings manage what we would in contemporary times would call othering. As other scholars have suggested, it involves coming to attitudes, dispositions, and forms of behaviour towards others through three key moves. The first move is that of classification, the second is attribution and the third is evaluation. In the first, people are classified and categorised in particular kinds of ways. Then, secondly, they are allocated membership of one or other of the categories. Finally, they are evaluated positively or negatively (see Zick, Kupper \& Hovermann, 2011). It is this three-step progression through a process of reasoning by which the Allport model has come to be known as the cognitive approach.

There are five levels in Allport's analysis. These levels, on a continuum of intensity, are antilocution, avoidance, discrimination, physical attack, and extermination. Antilocution, as the term implies, is the "talk" form. It is the least intense form of othering involving prejudice-laden forms of speech amongst individuals about others upon whom certain disliked social, cultural and other attributes are imposed. Extermination stands at the other end in this spectrum of prejudice. It involves the deliberate decision on the part of an individual or a group to eliminate, remove, or destroy another group based on their perceived attributes and characteristics. In-between, generally, but not always, in ascending order of both consciousness and scale, are avoidance, discrimination and physical attack. Avoidance is the escalation of speech to action - the decision to actually avoid individuals from groups projected as the object of dislike. Important about avoidance is its restriction on the self. It has no direct impact on those who are the object of dislike. It may also still remain within the confines of individual behaviour. Discrimination arises when 
an individual and more consequentially groups make the decision to exclude or withhold from others' rights and entitlements, such as access to public goods and facilities. Physical attack occurs when an individual or group moves to violence against an other or others who are the object of dislike.

Why prejudice exists and arises is a fundamental question in the discussion. This question was engaged in a deeply important debate between Allport and the German social theorist Adorno. The debate is important for a number of reasons, the most important, of course, is accounting for the scale and intensity of the holocaust. What had happened at a supposed apogee of civilisation was unprecedented in its barbarism. That six million human beings could be clinically and thoughtlessly exterminated demanded explanation. The intense moral confusion the holocaust brought on could not simply be consigned to history.

What was Adorno's thesis? Adorno and his colleagues argued that the rise of fascism in Germany was the result of an individual's personality type. Based on psychometric studies (including case studies and clinical interview), using what they called the F-scale (F for "fascism") they concluded that deep-seated personality traits predisposed some individuals towards harshness, cruelty, totalitarianism, and anti-democratic ideas. They described this as the authoritarian personality. Authoritarianism, characterised by nine different markers, they argued, predisposed people to prejudice (see Adorno, Frenkel-Brunswik, Levinson \& Sanford, 1950; McLeod, 2014). Of these, three were particularly significant, namely Conventionalism, Authoritarian Submission and Authoritarian Aggression. In terms of this, the authoritarian personality tended to have a rigid adherence to conventional attitudes and values, was hostile to those perceived to be of inferior status, deferential to those of supposed higher status, and had a tendency to condemn, reject, and punish those who did not conform to what was understood to be the convention (McLeod, 2014:13). Adorno et al.s (1950) own work attributed the authoritarian personality to a combination of socialisation and child-rearing patterns and family structure. In families where authoritarianism arose, typically, a strict father figure dominated the family structure. Others who have adopted this approach suggest that authoritarianism may also be, in part, genetic.

Allport and his colleagues' challenge to the Adorno thesis was not that the authoritarian personality did not exist, but that it did not explain how, amongst other things, whole social groups could be prejudiced. Was every person classified white prejudiced? Was every person considered male prejudiced against people considered female? It also implied, somewhat contradictorily, that all the members of a social group perceived to be bearers of prejudice would have to have an authoritarian personality. A key point Allport sought to make was that there was no such thing as a prejudiced personality type. 
Why people were prejudiced, Allport, his colleagues and the major group of scholars who have followed in his wake argued (see Roets \& Van Hiel, 2012:349), had to do with the fundamental cognitive need to make sense of the social space in which they found themselves. It is for this reason that the Allport approach has come to be called the cognitive approach. Roets and Van Hiel (2012) argue that "... some people really hate uncertainty and therefore rely on the most obvious information, often the first information they come across, to reduce it. (And that is why they favour authorities and social norms which make it easier to make decisions)." In relation to this, Allport and Pettigrew began their argument with the view that prejudice was not a personality trait. Personality, they suggested, was biologically determined at birth. Prejudice was something else. It was psychosocial. It arose in the process of the individual or the group making a judgement about another based on previous decisions and experiences (Allport, 1979) and could be understood as the use of a negative feeling, as in "thinking ill of others without sufficient warrant ... A feeling, favourable or unfavourable, toward a person or thing, prior to, or not based on actual experience" (Ponterotto, Utsey \& Pederson, 2006). Critically, it was located in consciousness - a faulty and inflexible generalisation - and had three components: a cognitive component, an affective component and a behavioural component. Allport, staying within the Freudian tradition, argued that what caused it was an

[u]nderlying insecurity that seems to lie at the root of the [prejudiced] personality. [This insecurity was the result of] unresolved infantile conflicts with parents or siblings ... [or] persistent failure in later years $[$ which $] ..$. Produced a crippled ego in need of a crutch. [In such personalities] prejudice ... develops as an important incident in the total protective adjustment ... central to which is repression ... Associated characteristic devices to bolster a weak ego ... include 'moralism', 'dichotomisation', a 'need for definiteness', 'externalisation of conflict', 'institutionalism', and 'authoritarianism': the earmarks of a personality in whom prejudice is functionally important.

(Allport, 1979:396-397)

Much of the current discussion about prejudice has followed in the theoretical footsteps of Allport and his colleagues. It proceeds on the basis that prejudice is based on social perceptions or attitudes towards others which are themselves based on stereotypes. These stereotypes may be deliberately taught as is the case in school systems all over the world where faulty "facts" about people who are supposedly different from oneself are actively propagated in the curriculum. However, they may also simply exist in implicit, unspoken, and unarticulated forms - gestures, reactions, and dispositions to others which circulate in the social spaces inhabited by individuals and groups. In both cases, they operate on the basis of attribution of internal properties to a person or a group based on external markers or characteristics of those persons or groups. The external markers could be both 
symbolic and physical - names with respect to the former, or physical attributes such as gender and skin colour with respect to the latter.

Formally, what one is seeing in the process of attribution is the unfolding of a complex relationship between the social and the psychological. Attempts to explain this relationship make it clear that the making of prejudice is not just simply social or psychological. It is in the interplay of the two. In this interplay are the following dimensions or elements: knowing, adjusting, value-expression and ego-defensive. Each element is fundamentally formed at the interface between the social and the psychological. It is about the social, as in the group, however the idea of the group is constituted, being processed through the cognitive apparatus of the individual, or what others have described as the mind in society. Knowing, as a result, is about making sense of experience in its primarily social form, and the need to understand the world. This is always accompanied by the need to adjust - to respond to the normative order. Adjusting is, therefore, responding to inducement or punishment, and the decision in relation to the stereotype to do or not to do those things which will secure for one approval and so inclusion. Again, this appears to be individualistic but is fundamentally about the individual responding to the social. Value-expression is that decision to use or adopt a stereotype to achieve self-actualisation and so a sense of integrity/identification with one's social environment. Ego-defensiveness is the shoring up of a stereotype to protect the ego against self-criticism. This last element is derived from Freud in his argument that people seek to displace their aggressions and frustrations in situations when they cannot direct their anger against the real cause of their frustrations, which may be located in some completely different issue or factor. This produces what he called scapegoating where frustration produces aggression and aggression frustration.

The power of this work is its appreciation of the multiplicity of social and psychological forces that are at work in combination - complex forms of personal insecurity underpinned by weak ego forms held together by prejudice.

Two derivative explanations of prejudice have developed in the last 30 years or so in response to criticisms of the perceived psychological or individualistic bias to this general theory. One is the theory of social dominance and the other is social identity theory. Social dominance has as its essential tenet the notion that dominant groups believe that there is a natural hierarchy amongst individuals and groups which justifies their attitudes and actions over those they deem to be their inferiors. This allows them to act out their feelings towards subordinate groups. Social identity theory was developed by the prominent social psychologist Tajfel in the 1970s. Tajfel, building on, first, the idea that individuals and groups when in the presence of others will instinctively make distinctions between themselves and those perceived to be other to themselves, and so will emphasise their own 
perceived social identity. Secondly, the idea that they will naturally stress their own positive self-image, argued that social identity lends itself to the production and reproduction of prejudice.

Three important versions of social dominance which have sought to lift the significance of the social in the making of prejudice are available in the work of Jackman (1994), Sidanius and Pratto (1993), as well as a stream of research building on the scholarship of Blumer (1958). Jackman, writing from a Marxist perspective, argued that racism emanated not from the psychological, but from group interest. Dominant groups created myths to justify and perpetuate existing inequalities. Racial beliefs including prejudices were "merely 'cognitive props' developed by the dominant group to effectively defend their dominance - not with force and hostility, but with, as Jackman calls it, a 'velvet glove”' (Krysan, 2000:151). A more psychological version of social dominance is offered by Sidanius and Pratto who argue that " $\mathrm{t}]$ he causal force behind group conflict (and by implication racial policy attitudes) is a human drive for group domination" (ibid.). Social dominance in this view is distinguishable from personality and individual characteristics and depends strongly on the legitimising myths of the dominant social group. Holding the focus of this chapter in perspective, the emphasis on hate, "Sidanius and his colleagues explicitly dismiss antiblack affect as an important predictor of racial prejudice ... What is important is one's attachment to the in-group, ethnocentrism, and a general ideology of group superiority" (Krysan, 2000:152).

Valuably, in cognisance of the discussion about the relative valence of the social and the psychological, inheritors of the Blumer tradition (1958) such as Bobo et al. (1997) (also see Bobo, 2000), have sought to locate prejudice, even in its individual expression, in its wider social context. Bobo (2000:140-143) suggested that:

The core argument here is that racial politics involves a nettlesome fusion of racial identities and attitudes with racial group interests. It suggests that many whites will oppose affirmative action not so much because they see a racebased policy as contravening their loftiest values or because they have learned a new, politically relevant set of resentments of blacks; but rather because they perceive blacks as competitive threats for valued social resources, statuses and privileges.

Two observations about this explanation are important to make. The first is its emphasis on the social. It suggests that groups (or individuals) make assessments about their interests which are derived from their perceptions of the realities of the conflicts in which they find themselves. These assessments "(are) not necessarily an objective assessment of [what those realities are]" (Krysan, 2000:153). So, for example, the perception of the threat of losing a job on the part of a white person could be underpinned by the prejudice that "blacks are pushing too fast" (ibid.). 
The second observation, pertinent for the discussion, is that the explanation does not work with these assessments in their psychological form. There is, it can be argued, insufficient reference to the affective.

What are we left with in this discussion? I would like to suggest, and this anticipates the discussion on hate which follows below, is that the discussion has helpfully foregrounded social factors in the reasoning processes involved in the making of prejudice. This description of the process of reasoning, however, I would like to suggest underplays emotion and the significance of affect in the ways in which individuals and groups structure their explanations for why they behave as they do. There is a need to bring affect into much clearer perspective to show how it produces what I would like to describe as bad cognition. The range of affective conditions, in all their positive and negative inflections, from mild preference and or distaste to searing love or hate, and their articulation with the cognitive needs much more empirical scrutiny. How emotion interacts with the cognitive is undoubtedly complex but needs to be understood. It is against this that the chapter turns to the significance of hate.

\section{Hate}

More than 60 years after Allport wrote The Nature of Prejudice we are now beginning to think more deliberately about where the phenomenon of hate fits into this framework of prejudice. Behind this development are two issues of concern. The first is analytic. It has to do with the need to distinguish hate more clearly within the spectrum of psychological dispositions involved in the phenomena of racism, sexism and other forms of discrimination. Its loose use and somewhat profligate deployment in making sense of all forms of bias, discrimination and othering (around whatever form of identity or object of attention) is unsatisfactory. This leads to the second concern, that of how we should be acting - the realm of the political. This concern is about how to make sense of hate so that we can act in ways that are politically appropriate and meaningful. In light of both the persistence and the apparent shifts in the forms and dynamics of racism, there is a need to understand it better in order to respond to it more efficaciously.

The most significant theorist on hate in the contemporary period is Robert Sternberg (2003) (see also Sternberg and Sternberg, 2008). Sternberg (2003:299) makes the point that "the dictionary definition of hate is "to have strong dislike or ill will for; loathe; despise", or "to dislike or wish to avoid; shrink from". These, he says, serve as useful starting points but are not sufficiently detailed as an ending point. Interestingly, in his unfolding of his Duplex Theory of Hate, he himself does not venture a more satisfactory definition. What he does do, and this is sufficient, 
it is suggested here, is develop a theory of what it is. This theory rests on five fundamental claims about hate. These are that:

1. Hate is very closely related psychologically to love.

2. Hate is neither the opposite of nor the absence of love.

3. Hate, like love, has its origins in stories that characterise the target of the emotion.

4. Hate, like love, can be characterised by a triangular structure generated by thesestories.

5. Hate is a major precursor of many terrorist acts, massacres, and genocides.

(Sternberg, 2005:38)

I return to this below.

In an important intervention in what hate is, Royzman, McCauley and Rozin (2005:27) take issue with descriptions of the phenomenon, which essentially make it either what they call ostensive or stipulative in its form. An ostensive description or definition essentially is one which invokes what are thought to be examples of the condition to define the condition itself: "... a definiens is communicated by either literally pointing to or otherwise indexing a case in which the definiendum is thought to be in evidence ... Thus, one may give an ostensive definition of 'pain' by pointing to a person in the throes of a toothache and saying ... 'This is what pain is like" (ibid.). A stipulative definition constructs the content of hate and then goes to look for it (Royzman et al., 2005:22). It is essentially self-validating. Hate in both these approaches is whatever is going on. One sees Royzman and his colleagues' argument clearly in the two references cited here of Sternberg. In the first, he describes what the components of hate are; in the second, he develops his taxonomy of types of hate. For the record, he says that hate has three components: the negation of intimacy where individuals or groups seek to place distance between themselves and others because others arouse repulsion and disgust in them; passion which could take the form of anger or fear in response to a threat; and decision-commitment which is marked by cognitions of devaluation and diminution through contempt for the target group (Sternberg, 2005:39). These three components generate seven different types of hate, cool hate (negation of intimacy), hot hate (passion alone), cold hate (decision-commitment alone), boiling hate (disgust of negation of intimacy plus passion), simmering hate (negation of intimacy plus decision-commitment), seething hate (passion plus decision-commitment) and burning hate (negation of intimacy plus passion plus decision-commitment) (Sternberg, 2005:30-40). 
Royzman and his colleagues (2005:31), interpreting this literature, come to the following conclusion:

Our analysis leaves us uncertain about the much-cited link between hate and intergroup violence such as genocide, ethnic riots, or hate crimes. If hate is defined ostensively through paradigm cases of armed conflict and killing, then the notion that hate is responsible for mass violence is a tautology. Conversely, if hate is to be spelled out in terms of its lay meaning, as a form of inhibited defiance, or in terms of a stipulated meaning, for example, as a syndrome of inverse caring, then the empirical evidence for the link between hate and intergroup violence remains to be seen. That is the very status of hate as a progenitor of evil rests on a prior conceptual decision about which phenomenon one is willing to probe under the heading of hate and which one will opt to see as 'being not about hate at all'.

Given these challenges, they are reluctant to describe hate in categorical terms. There is no single formulation, they say, that will satisfy the demands posed by any interpretation of what hate is. Following this opening gambit for making sense of hate, Susan Opotow (2005:122) helpfully says that "the psychological study of hate has a curious centrifugality that deals with particular manifestations of hate, but offers few cross-contextual analyses that examine the core meaning of hate across contexts". To take the discussion forward, Royzman et al. return to an explanation provided by Shand (Royzman et al., 2005:5) who wrote in the 1920s. Shand described hate as a bundle of episodic dispositions united by a common emotional object or a common category of such objects. It was the perfect antinomy of love. Love involved the positive alignment between the emotions of the lover and the fortunes of the beloved. Hate was the alignment in the negative: "It was neither a special emotion nor a blend of emotions, but rather a tendency to emote in a number of ways to a number of situations involving the object of hatred" (Royzman et al., 2005:6). Irwin Staub (2005:52) describes hate in similar terms:

$[\ldots]$ hate is built out of a complex of cognitions and emotions. The cognitive components are likely to include devaluation or a negative view of some other and the perception of threat from that other. The emotional components are likely to include dislike, fear, anger, and hostility. Another likely element of hate is a sense of rightness or justice about acting against the object of one's hate.

This can take ideological form - the belief that a desirable ideal will produce a better world. Opotow (2005:125), reading the literature on hate, described it as a "compound construct mingling anger and aggression ... its emergence is relational, cumulative and a response to attacks on one's personhood". 
It is this difficulty of the compound nature of hate, I want to suggest, that has led to its loose use in many contexts and situations - most notably in the evocation of the phenomenon of hate crimes.

Some issues: How do prejudice and hate work?

Do they work differently?

With this explanation above, can one say that hate is categorically different to prejudice? Does it consist of different elements to that of prejudice? The fullest explanation of how hate works is available in the writing of Sternberg (2005). He suggests that the basic processing system "that applies to the formation and processing of impressions about groups and individuals is the same" (Sternberg, 2005:38). What is this processing system?

Sternberg's processing involves the three components described above: negation of intimacy or distancing, passion, and decision-commitment. Distancing arises from the arousal of repulsion or disgust an individual or group feels in relation to a person or group. It may arise from the actions of the person or a group, or is stimulated by propaganda which depicts the person or group in subhuman or less than human ways. Passion in hate expresses itself in anger or fear in response to a threat, and decision-commitment is characterised by cognitions of devaluation and diminution through contempt for the hated group. These components generate in various combinations the seven types of hate described above. In their accumulation and combinations, these elements generate three levels of danger: mild hate-based when one of the components is present, moderate hate-based danger when two of the components are present, and severe hate-based danger when all three of the elements are active (Sternberg, 2005:41). Sternberg takes this process explanation a step further by invoking the idea of the story-based underpinnings of the development of hate. Hate does not simply arise. It is, he says, fomented. It is fomented by people who use stories to find self-esteem by devaluing others. Important about the story is that it is constructed around a stereotype. That stereotype, however, is utterly threatening. It is portrayed as the embodied evil and danger. The purpose of the threat is to activate distancing, passion, and decisioncommitment.

When one compares this description of the internal make-up of hate to that of prejudice as described by Allport, is there a significant difference? Tony Jefferson (2015), a criminologist, is useful here. In a searing analysis, he argues that, actually, in explanations such as these an elision takes place in the general discussion. This elision is the blurring of the lines between emotion and cognition: “... $[\mathrm{t}]$ he emotional dimension of hatred and the cognitive dimension of prejudice 
have become erroneously elided (to the detriment of properly understanding either: the notion of positive prejudice completely disappears, for example)." The point he makes is that there is a difference between hatred and prejudice and that they have different origins. While there is a connection between them, prejudice does not automatically progress to hatred. Criticising Allport, he comments:

$[\ldots]$ for all his contributions to the cognitive dimension, he was unable to come to grips with the emotional investment involved in extreme prejudice (or hatred) that he himself acknowledged needed to be understood. From this point on, a cognitive approach to prejudice and othering came to dominate research into racism yet without giving up the idea that it was attempting to explain the hatred involved in genocide.

(Jefferson, 2015:129)

In making sense of Jefferson's argument, it can be easily deduced that he is saying that hatred is characterised by extreme emotion and that it is the emotional intensity of hatred which distinguishes it from milder forms of prejudice. This would, however, be simplifying the argument to a banality. There is, I want to argue, some merit in his insistence that there is a difference between prejudice and hate and the urgency he conveys in his work that we should understand hate better.

But there remains the task of saying more clearly what the differences between prejudice and hate are. To help in this task Jefferson looks to the work of YoungBruehl (1996) who challenged the idea that prejudice was a unitary phenomenon and that the various expressions it took were simply variations on a theme. Her argument was that it was possible to identify and locate distinct causes in different kinds of prejudice and so, for example, in anti-Semitism one saw the emergence of what she called the obsessional type who saw Jews as dirty and aggressive. Racism stemmed from a hysteria which was rooted in sexual fear and homophobia. A major issue in her argument is the role of unconscious desire in racism, sexism, and antiSemitism. This desire is distinct from the conscious love of one's own group, she suggested, that was behind much of prejudice.

Jefferson does not entirely go along with Young-Bruehl's use of character types and the almost fixed ways in which she deploys the idea of types in coming to understand behavioural outcomes. "This is partly because", he says, "the idea of character (like personality) does not convey the incessant dynamics underpinning behaviour for which a processual analysis is more appropriate". But, and this is the value of his intervention, he suggests that there is a developmental trajectory in how what we might understand to be the ways in which prejudice progresses to hate. It is this that is useful because what he is doing in this analysis is suggest that there are socially contingent factors that become relevant in the dynamic that plays itself out in a person's life. What happens in this analysis is not the inevitability of particular forms of behaviour, but an explanation which brings together the psychological 
- the types - and the social - the circumstances in which people find themselves, in ways which are clearer: "What it means, very simply, is that particular types of prejudice will flourish in societies where the associated character types are enabled in some ways." (Jefferson, 2013:13)

\section{A way forward: Between prejudice and hate}

Critical in understanding how to move forward in the discussion about the relationship between prejudice and hate, is understanding the nature of Jefferson's objection. Useful as his assertion is that an elision takes place in much of the discussion, I would like to suggest that there is sufficient evidence in the existing discussion to justify holding prejudice and hate together as not only cognate but fundamentally related phenomena. Both involve cognition, belief, and attitude. The presence of these elements allows one to map Sternberg's seven types of hate onto Allport's five different levels. What is different between them is the emphasis Sternberg places on emotion - hate is fomented he says - and the way in which he locates emotion as an activating factor in the direction which prejudice takes. A point to emphasise is that emotion/affect is not absent in the Allport analysis. His five-level explanation of prejudice includes the suggestion that, under certain circumstances, an individual or a group will take steps to move from simply harbouring an attitude, what he called antilocution or even avoidance, to acting on his or her attitude, what he called physical attack and extermination. In describing these phases, Allport was careful to talk about the social conditions in which they occurred. Ponterotto and his colleagues (2006:15) quote Allport's description of the physical attack phase and make the point that " $[\mathrm{u}]$ nder tense and emotionally laden conditions, or even under peer pressure, it does not take much for an individual to move from the discrimination stage to the physical confrontation ..." It was Hitler's antilocution pressure, Allport argued, which made it possible for Germans to cross the boundary to taking the decision to embark on a process of exterminating people who were classified as Jews:

It was Hitler's antilocution that led Germans to avoid their Jewish neighbours and erstwhile friends. This preparation made it easier to enact the Nurnberg laws of discrimination which, in turn, made the subsequent burning of synagogues and street attacks upon Jews seem natural. The final step in the macabre progression was the ovens at Auschwitz.

However, Allport does not distinguish the activating dimensions of the experience enough. Directly relevant to his theoretical gathering, together with what is taking place here, is his description of "emotionally-laden conditions". But, powerful as this invocation is, he does not, in explaining the cognitive processes that are at work here, make sufficient allowance for the work that emotion does. Cognition, as a process of acquiring thought and sense-making, is rendered too restrictively 
as a social experience. What this leads to, I suggest, is the need for emphasising the covalence of the affective alongside the cognitive, and a restatement of the prejudice continuum in a way which accommodates processual or fomenting factors, especially those which are emotional. How this may be done is to recompose each of Allport's five stages and include within such a recomposition not only the behavioural forms associated with each type, but the full complexity of social and psychological forces that are present. This would reconfigure the model not simply as a typology or a classification of types of prejudice, but as a syndrome of fluid complexes or structures which have inside of them interactive cognitive, emotive and behavioural factors. What such a model makes possible is in direct response to the second remaining concern I draw attention to above, the identification of hate inside its psycho-social ecology. The opportunity this presents is that of working with Jefferson's idea of enablement, of seeing much more distinctly the ways in which the social and the psychological interact to catalyse, or indeed their opposite, to neutralise or stabilise each other. The value of this approach lies in entering, more explicitly, the space in which the encounter between the mind and its social environment plays itself out, and towards understanding the processual nature of the experience, establishing what the constants and variables are that arise. The opportunity it presents is that of developing a framework, as opposed to a schema, for identifying the distinct psychological and social conditions that arise in combination in what I would describe as the zone of enablement and for understanding the complex and unpredictable ways in which these play themselves out.

In bringing this part of the discussion to a close, a final comment on enablement is necessary. In the general thread of argumentation used in many explanations of enablement, it is said that it is often people's experiences which confirm their attitudes. The work of Minard (1952) and Pettigrew (1959) has been helpful here. At the core of that work is a concern to explain the shifting behaviour of groups of people in different contexts. This work emphasises some of the complexity of prejudice and how it works. It is neither stable and consistent nor fixed and permanent in either its forms or the outcomes it will produce. The forces which animate it produce shifting dynamics and variable outcomes. Minard's (1952) work, to illustrate, shows what the complexity is. More than 60 years ago, he conducted a study of a group of black and white miners in a town in the southern United States. He looked at their attitudes towards each other when they were below ground and then again when they were above ground. The conclusion to which he came, to explain what was happening, was that the social norms of the two spaces were distinct and came to effect how people behaved and particularly how they managed their prejudice. The norm below ground was towards friendliness between miners. Above ground it was the reverse. Enabled above ground were 
attitudes that were effectively disabled below ground. This is helpful in thinking of enablement, but even so it is not sufficient. What needed to be understood was the way the normative order worked, its compulsions and prohibitions, why it sometimes stimulated agency, negative agency, and why sometimes not (see the recent work of McLeod, 2008). Why is the norm, as an activational device, functional and sometimes not? (Jacobs et al., 1998). What this points to is the need for recognising the general but unique features of each event or incident.

In closing this discussion, I refer briefly to the case of Barend Strydom, the perpetrator of one of contemporary South Africa's most important examples of how hate works. Strydom was the self-proclaimed founder and leader of a white supremacist group, Die Wit Wolwe. Die Wit Wolwe was established in Pretoria in 1988 by a group of 21 Afrikaners for the purposes, as they explained at their founding meeting, of

1. The advancement of Protestant Christianity.

2. The identification, exposure of and struggle against, particularly, the ANC/ SACP Alliance, Satanism, Communism, Marxism, Humanism, Liberalism, Free Masonry, the Broederbond, the International Monetary Fund and all their front organisations, with whatever means we have at our disposal.

3. The establishment of our own free Christian Republican Boerevolkstaat. (Strydom, 1997:57)

In the afternoon of 15 November 1988, Strydom, then 23 years old, made his way to Strijdom Square in the city of Pretoria armed with a hunting knife, a $9 \mathrm{~mm}$ Parabellum Beretta Pistol and over 500 rounds of ammunition. He had a mission to accomplish - die "Slag van Strijdomplein", rendered less dramatically in English as "the Battle of Strijdom Square" - to take the battle for the freedom of the Afrikaner people to the enemy. On the morning of the event, Strydom had gathered with three confederates at the Voortrekker Monument and agreed there that he should be the one to see through the implementation of the plan to attack the enemy in the heartland of Afrikanerdom, the city of Pretoria. He had phoned the media before the operation and told them that the event of which they had been warned was about to happen. He strode onto the square and within 15 minutes had hunted down and killed seven people. A week before, Strydom had undertaken a practice run. He had driven to Weiler's Farm, an informal settlement in De Deur South of Johannesburg, randomly identified a shack and shot at two of its sleeping occupants, killing one. Because it was a rainy night, the operation, he said, was not entirely successful. But he had proved to himself that he could kill - he had become a freedom fighter (Strydom, 1997:75). By the time he was arrested at Strijdom 
Square, he had murdered eight people. Strydom was arrested and quickly brought to trial. The trial judge, Mr Louis Harms, told him in finding him guilty that:

If the sentence creates the impression that I want you kept permanently out of society, then that impression is correct. There is no hope of rehabilitation for you. You have no remorse and you would happily repeat what you have done. Your crimes were barbaric, the consequences indescribable. It was premeditated and carried out without feeling. In the interests of the community, you should be removed. You remain a danger.

(Smith, 2008:par. 3-5)

Yet, in seeking to characterise what had happened in this critical period of South African history, this episode did not lead to what Strydom had hoped for, an allout war between white and black people. The sacrificial role he saw himself playing did not proceed to a generalised process of extermination of black people. While he received a great deal of support from other Afrikaners, very few followed his example. There were, in the context, sufficient conditions which inhibited and even stopped large numbers of people to act on their prejudices. They did not cross the boundary from belief of their superiority to physically attacking black people.

But Strydom's hate still needs to be explained. Judge Harms (Document K29.2037:687-688), in assessing the expert testimony, came to the conclusion that the only factor which bears a causal relation to the deed was his political beliefs and feelings of hate. As far as his hatred was concerned, Harms (ibid.) said,

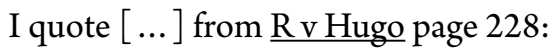

'Now it seems to me that a settled hate or bias against a person does not by itself constitute an extenuating circumstance whether there is foundation for it or not. A normal man cannot allow the prejudices or antipathies which are ordinarily kept within reasonable bounds to become so exaggerated as to lead him to kill a human being. It is not every warped or prejudiced mind that can be said to be suffering from a 'delusion, erroneous belief or defect.' There must be a clear element of abnormality. The clouding of a normal brain by hatred goes no further than the motives giving rise to hatred.'

He came to the conclusion that Strydom was driven by pure political fervour. He did not accept that what had happened was explainable in terms of Strydom's personality.

In explaining the extreme forms of behaviour that came to be enacted, I would like to suggest that the summing up of the judge was legally correct. He dismissed the salience of influences such as Strydom's age and his upbringing and concluded that the "the only factors that really have a causal bearing here were his (Strydom's) political beliefs and his feelings of hate" (Document K29.1920:31) (Soudien's translation from the Afrikaans). His assessment of the expert testimony before 
him was based on a careful separating out of fact and conjecture. He could not, he emphasised, find any basis for the psychologist for the defence's contention that an experience of extreme trauma had occurred in Strydom's life such that he was impelled to kill: "There was no such evidence" (ibid.).

What Judge Harm's summing up does is support the general approach taken by Staub. As cited earlier, Staub (2005:52) had described hate as being:

[...] built out of a complex of cognitions and emotions. The cognitive components are likely to include devaluation or a negative view of some other and the perception of threat from that other. The emotional components are likely to include dislike, fear, anger, and hostility. Another likely element of hate is a sense of rightness or justice about acting against the object of one's hate.

Confirmatory as this legal reasoning is of the general hate literature, it leaves, still, the central issue of how to account for, as in Allport's (Ponterotto et al., 2006:15) description, "mov(ing) from the discrimination phase to the physical confrontation stage", or in Jefferson's (2013:13) approach, the processual development trajectory from prejudice to hate. Harm's summing up contained all the general elements required to come to an accurate forensic assessment of what was at play in the case. It did not deem it necessary, however, to deconstruct the processual nature of the events. Such a deconstruction would have been useful and would have given the Strydom narrative its contextual specificity. Central to that specificity, in attempting to take the analysis forward, are Jefferson's dynamics which take Strydom, and virtually nobody else, from one state of consciousness to another.

What happens which makes Strydom cross the boundary from prejudice to hate? Central, I would like to argue, and this is effectively minimised and not used as an opportunity for deconstruction, is what Judge Harms distilled as the question of Strydom's political beliefs. His political beliefs, said Harms, were the cause. The activating factor not referenced in the trial was the intense testing of Strydom's political belief. That testing was essentially the dismantling of apartheid. The period was marked by the release of Nelson Mandela from prison and the unbanning of the African National Congress (ANC), the Pan African Congress (PAC) and the South African Communist Party (SACP). South Africa, at that moment, was passing over from white supremacy to becoming a democracy. This moment in the history of South Africa was deeply traumatising for Strydom. He would open his Belydenis (Confession) with the following line:

Van kleins af het ek geywer vir onse God en die Boerevolk. Ek het 'n roepingstaak-ervaring belewe deurdat ek moes opstaan ... Besetting van Boergrond was aan die orde van die dag, dit moes plek maak vir plakkers ... Dit word 'n amptelike onverklaarde oorlog. Ons bejaardes word wreed aangerand, verkrag en vermoor. Daar word met ' $n$ bus in die Westdene-dam 
gery en 48 Boereseuntjies and dogterjies sterf ... Is dit beskaaf of barbaars? Uit God of uit satan? Dis alles deel van'n uitgewerkte plan teen die Boerevolk ... [Nou] verwag Hy ook van ons om hulle wat sy naam to belaster dood te maak ... (Strydom, 1997:7-9) [I devoted myself from childhood to our God and Boer nation. I experienced a calling to take a stand ... The occupation of our land was the order of the day. We had to make way for squatters ... An official undeclared war was begun. Our older folk are being brutally assaulted, raped and murdered. A bus with 48 Boer boys and girls was driven into Westdene dam leading to their deaths ... Is this civilised or barbaric behaviour? Is it of God or Satan? ... This is all part of a plan against the Boer nation. God expects us now to kill all those who abuse his name.]

For Strydom, whose normative order was constructed around the predestined superiority of white people, the possibility of living alongside of and as an equal to black people was unthinkable. He had committed himself from his final years at school already to fighting for the rights of the Afrikaner people. He had written letters of remonstration to all the major black South African leaders and internationally to figures such as Margaret Thatcher. When F.W. de Klerk announced the unbanning of the ANC and the release of Mandela, it was a moment of immense betrayal for him. He had found even the establishment of the tri-cameral parliament, with separate chambers for whites, "coloureds" and "Indians", and the ensuing acknowledgement of Islam and Hinduism, deeply objectionable. That people of different faiths were even sitting next to Christians caused him great hurt. In the course of his trial, the judge asked him if he believed that only white people were deserving (of God's) favour. His reply was: "That is correct ... In the documents of the Great Trek ... black people are not regarded as people but as animals" (Strydom, 1997:121) (translated by Soudien from the Afrikaans).

In attempting to make sense of the holocaust, Staub (1989:98) argued that predisposition to fanaticism did have roots in a person's childhood and personality, but once this was coupled to an ideology, "knowledge of the ideology ... [wa]s the best guide to understanding his behaviour". Staub is correct. He said that when Hitler was growing up, he was surrounded by a society soaked in anti-Semitism. What converts this anti-Semitism to racial hatred and, consequently, to genocidal action is, however, not sufficiently elaborated on. The answer, it is argued here, is necessary for explaining how prejudice advances to hatred. In the case of Germany, as Staub himself explained, the contextual circumstances of the 1930s, "[of] a people distressed by inflation, depression, joblessness, and political chaos, togetherness and unity had wide appeal" (Staub, 1989:99). This contextual explanation does not provide the neat clinical explanation of cause, but it is essential in making sense of the complexity of the dynamic in which the Germans found themselves. There were, in the cultural life of the Germans, inclinations to authoritarianism. This impacted on behaviour. But it was when this behaviour 
was embedded in and available to political ideology that a particular combustive trajectory was inaugurated. Similarly, when Strydom was coming to adulthood, he was doing so in an environment normatively constructed around white supremacy. This white supremacy was elemental and pervasive in all the formative spaces in which he found himself - his family home, his church and his schooling. It was the disruption of this normative order, it is argued here, that came to move that normative order from prejudice to hate, from belief to action. Why, however, this did not become a generalised reaction in the Afrikaner community remains a question. It was sufficient to cause Strydom to move to hate but not for the wider Volk amongst whom he lived. It is this complexity in each of the contexts in which hate arises that requires elaboration.

What are we to take away from this discussion in understanding prejudice, hate and racism? The most important is that while prejudice and hate are related, and while it is possible to bring the contemporary discussion of hate, as it is elaborated by scholars such as Staub and Sternberg, into conceptual alignment with the way prejudice is mapped out by pioneers such as Allport, and, thereby, to confirm the general features of the prejudice-hate schema, there is need to recognise the distinctiveness with which hate manifests itself and comes to work. Hate, the point needs to be made, coincides with and is qualitatively similar at points to the different forms of prejudice identified by Allport, but, at moments or even periods, takes on a distinctive form which requires acknowledgement and explanation. This distinctiveness may be accommodated in Allport's categories, avoidance, discrimination, physical attack and extermination, but these do not descriptively enough contain or, by themselves, explain the concentration of intense emotion, cognition and action embodied by the descriptor hate and bring us to a definitive understanding of what is going on in the othering experience. Simple dislike may be present in all Allport's forms, especially avoidance and discrimination, but the intensity and effects of the combination of factors distinguishing hate calls, each time, for further study. 


\section{References}

Aboud, F. 1988. Children and Prejudice. New York: Blackwell.

Adorno, T.; Frenkel-Brunswik, E.; Levinson, D. \& Sanford, N. 1950. The Authoritarian Personality. New York: Harper \& Row.

Allport, G.W. 1954. The Nature of Prejudice. Reading, MA: Addison-Wesley.

Allport, G. 1979. The Nature of Prejudice. Unabridged edition. Cambridge, MA: Perseus Books.

Baird, R.M. \& Rosenbaum, S. 1999. Hatred, Bigotry and Prejudice: Definitions, Causes and Solutions. Amherst, NY: Prometheus Books.

Blumer, H. 1958. Race prejudice as a sense of group position. The Pacific Sociological Review, 1(1). https://www.jstor.org/ stable/1388607

Bobo, L. 2000. Race and beliefs about affirmative action: Assessing the effects of interests, group threat, ideology, and racism. In: D. Sears, J. Sidanius \& L. Bobo (eds.). Racialized Politics: The Debate About Racism in America. Chicago, IL: University of Chicago Press.

Bobo, L.; Klugel, J. \& Smith, R. 1997. Laissez Faire racism: The crystallization of 'kinder, gentler' anti-Black ideology. In: A. Tuch \& J. Martin (eds.). Racial Attitudes in the 1990s: Continuity and Change. Westport, CT: Praeger.

Davidio, J.; Hewstone, M.; Glick, P. \& Esses, V. (eds). 2010. The SAGE Handbook of Prejudice, Stereotyping and Discrimination. Thousand Oaks, CA: Sage.

Dawkins, R. \& Wong, Y. 2005. The Ancestor's Tale: Pilgrimage to the Dawn of Evolution. New York: Houghton Mifflin Harcourt.

Delamontagne, R.G. 2012. Relationships between varieties of religious experience and manifest. Journal of Religion and Society, 14. http://hdl.handle. net/10504/64310
Document K29. Finding in the High Court of South Africa (Transvaal Provincial Division) Pretoria. 1989-05-25. The State against Barend Hendrik Strydom.

Edwards, A. 2003. Human genetic diversity: Lewontin's fallacy. BioEssays, 25(8). https:// doi.org/10.1002/bies.10315

Fields, K. \& Fields. B. 2014. Racecraft: The Soul of Inequality in American Life. New York: Verso.

Hofmeyr, J. \& Govender, R. 2015. National Reconciliation, Race Relations, and Social Inclusion: South African Barometer Briefing Paper 1. Cape Town: Institute for Justice and Reconciliation.

Jackman, M. 1994. The Velvet Glove: Paternalism and Conflict in Gender, Class and Race Relations. Berkeley, CA: University of California Press.

Jacobs, B.J. \& Potter, K. 1998. Hate Crimes, Criminal Law \& Identity Politics. Oxford: Oxford University Press.

Jefferson, T. 2013. Masculinity, sexuality and hate-motivated violence: The case of Darren. Crime Justice Journal, 2(3). https:// doi.org/10.5204/ijcjsd.v2i3.119

Jefferson, T. 2015. What is racism? Othering, prejudice and hate-motivated violence. Crime Justice Journal, 4(4). https://doi. org/10.5204/ijcjsd.v4i4.261

Krysan, M. 2000. Prejudice, politics, and public opinion: Understanding the sources of racial policy attitudes. Annual Review of Sociology, 26(1). https://doi.org/10.1146/ annurev.soc.26.1.135

McCann-Mortimer, P.; Augoustinos, M. \& LeCouteur, A. 2004. 'Race' and the Human Genome Project: Constructions of scientific legitimacy. Discourse and Society, 15(4). https://doi. org/10.1177/0957926504043707

McLeod, S. 2014. Theories of Personality. Simply Psychology. https://www. simplypsychology.org/personality-theories. html [Accessed 23 March 2017]. 
Minard, R. 1952. Race relationships in the Pocahontas Coal Field. Journal of Social Issues, 8(1). https://doi.org/10.1111/ j.1540-4560.1952.tb01592.x

Opotow, S. 2005. Hate, conflict and moral exclusion. In: R.J. Sternberg (ed.). The Psychology of Hate. Washington, DC: The American Psychological Association.

Pettigrew, T. 1959. Regional differences in anti-negro prejudice. Journal of Abnormal Social Psychology, 59(1). https://doi. org/10.1037/h0047133

Ponterotto. J.; Utsey S. \& Pederson, P. 2006. Preventing Prejudice: A Guide for Counsellors, Education and Parents. Thousand Oaks, CA: Sage. https://doi. org/10.4135/9781452225678

Risch, N.; Burchard, E.; Ziv, E. \& Tang, H. 2002. Categorization of humans in biomedical research: Genes, race and disease. Genome Biology, 3. https://doi. org/10.1186/gb-2002-3-7-comment 2007

Roets, A. \& Van Hiel, A. 2012. Allport's prejudiced personality today: Need for closure as the motivated basis for prejudice. Current Directions in Psychological Science, 20(6). https://doi. org/10.1177/0963721411424894

Royzman, B.; McCauley, C. \& Rozin, P. 2005. From Plato to Putnam: Four ways to think about hate. In: R.J. Sternberg (ed.). The Psychology of Hate. Washington, DC: The American Psychological Association.

Sidanius, J. \& Pratto, F. 1993. The dynamics of social dominance and the inevitability of oppression. In: P. Sniderman \& P. Tetlock (eds.). Prejudice, Politics and Race in America Today. Stanford: Stanford University Press.

Smith, J. 2008. What Became of the Big Wit Wolf? IOL. https://bit.ly/2NtqidL [Accessed 23 March 2017].

South African Hate Crime Working Group. 2012. Violent Hate Crime in South Africa. https://bit.ly/2RkijAx [Accessed 20 September 2019].
Staub, E. 1989. The Roots of Evil: The Origins of Genocide and Other Group Violence. Cambridge: Cambridge University Press

Staub. E. 2005. The origins and evolution of hate, with notes on prevention. In: R.J. Sternberg (ed.). The Psychology of Hate. Washington, DC: The American Psychological Association.

Sternberg, R.J. 2003. A duplex theory of hate: Development and application to terrorism, massacres, and genocide. Review of General Psychology, 7(3). https://doi. org/10.1037/1089-2680.7.3.299

Sternberg, R.J. 2005. Understanding and combating hate. In: R.J. Sternberg (ed.). The Psychology of Hate. Washington, DC: The American Psychological Association. https://doi.org/10.1037/10930-000

Sternberg, R.J. \& Sternberg, K. 2008. The Nature of Hate. Cambridge: Cambridge University Press. https://doi.org/10.1017/ CBO9780511818707

Strydom, B. 1997. Barend Strydom: Die Wit Wolf. 'n Belydenis. Mossel Bay: Vaandel Uitgewers.

Sullaway, M. 2004. Psychological perspectives on hate crime laws. Psychology, Public Policy, and Law, 10(3). https://doi. org/10.1037/1076-8971.10.3.250

Sullivan, S. 2001. Pragmatism, psychoanalysis, and prejudice: Elisabeth Young-Bruehl's The Anatomy of Prejudices. The Journal of Speculative Philosophy, 15(2). https://doi. org/10.1353/jsp.2001.0025

Young-Bruehl, E. 1998. The Anatomy of Prejudices. Cambridge, MA: Harvard University Press.

Zick, A.; Kupper, B. \& Hovermann, A. 2011. Intolerance, Prejudice and Discrimination: A European Report. Berlin: Friedrich-Erbert Stiftung. 


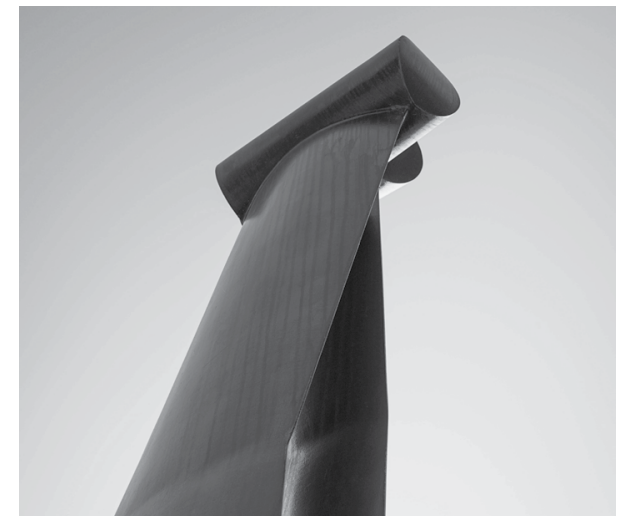

2

\title{
AN UNLIKELY TURNING POINT \\ Skin bleaching and the growth of colourism in South Africa
}

\author{
Nina G. Jablonski
}

We often consider turning points in history to be major singular events like assassinations, earthquakes, and military coups that have an immediate impact on public life or policy. Many significant turning points are not, in fact, singular events and - at the time they occur - are often not seen as momentous. Viewed in retrospect, though, they loom large because of their transformative power. The introduction of new products or the inauguration of popular trends can be turning points because they can affect how people go about their lives or think about themselves as conscious actors in society. Terence Turner's concept of "social skin" resonates here because skin itself acts as an interface for political, cultural, and social identity (Turner, 2012). In South Africa, the introduction of specific personal care products for the transformation of personal appearance, specifically the introduction of skin lighteners and hair straighteners, was an important, if unlikely, turning point. In the twentieth-century history of the country, these products made possible the alteration of perceived racial identity when "black" physical features were associated with inferiority and limited physical and social 
mobility. The continued use of these products after the apartheid era denotes their continued power to transform self-perception and to lessen the perceived burden of blackness.

Skin and hair are two of the most highly visible traits of the human body and the human social interface. These attributes are amongst the most important signifiers of age, ancestry, and attitude, and are some of the most important signals in the human nonverbal communication repertoire. People are assessed and judged by the appearance of their skin and hair (and clothing) and learn - in late childhood and adolescence - to navigate and manipulate social interactions by modifying the appearance of their skin, hair, and raiment. Modification of skin colour in the United States and South Africa is associated with multiple levels of social meaning because of its effects on race identity as well as on status within a race (colourism). In this chapter, I explore the specific effects of the development, commercialisation, and use of skin lighteners in apartheid era South Africa, and make the case that this innovation was a turning point in the history of race and racism in the country.

\section{Skin lightening in historical context}

Cultural preferences for light skin have arisen independently many times and have been reinforced when complementary "cultures of lightness" have come into contact with one another. The rise of agricultural and increasingly stratified economies throughout the Old World in the last 6000 years coincided with the division of populations into groups that spent most of their days working outdoors and those that spent the majority of their time indoors. The associations of darker, tanned skin with outdoor toil and hard physical labour and of light skin with relative leisure and affluence, led to light skin becoming a signal of higher social status in most agricultural societies worldwide (Jablonski, 2012). The public display of light skin was of great social importance in Eastern Asia and in Western Europe from the sixteenth through eighteenth centuries, but lightness took on new meanings and enhanced value as European colonies in the Americas prospered through the labour of imported dark-skinned slaves from Africa. Preferences for light or relatively light skin do not appear to have been widespread in Africa prior to widespread contact with Europeans, except in the Lower Nile of ancient Egypt, a hotspot of cultural and genetic intermingling. By Roman times, if not before, light skin was valued - especially in women - as a sign of privileged ancestry and lifestyle. Cleopatra (69-30 BC) took pains to keep her skin light, and her practice of bathing in asses' milk for the purpose of skin lightening is legendary but possibly apocryphal.

Having relatively light skin became synonymous with success and happiness, and people over the ages have sought to become lighter by various means (Jablonski, 2012). In parts of the world today, the sheer knowledge that a preference for 
lightness is associated with higher status elsewhere is sufficient to promote desires for skin lightening and sales of lightening products. Lighter appearing skin can be achieved by using whitening cosmetics, bleaching agents to decrease the production of melanin pigment in the skin, or a combination of both. Whitening cosmetics and skin bleaches have been used for nearly two thousand years, but only in the last century has the production of these materials become sophisticated, commercialised, and highly profitable.

Favoured formulas for skin lightening agents developed independently in Europe and East Asia. The popularity of white makeup and lightening preparations increased even though their toxic ingredients caused a myriad of health problems. Illness was not sufficient to discourage the use of white cosmetics and lighteners. However, for many, the drive to achieve social approval or advancement through lightness was worth the risk. What was remarkable about the history of skin whitening before the nineteenth century, was that it was the province of genetically light-skinned people. Those already light wanted to look lighter because whiteness signified freedom from outdoor toil as well as spiritual purity (Jablonski, 2012). Skin lighteners and lightening cosmetics took on different roles when they were adopted by people with dark skin, including dark-skinned South Africans living under Dutch and English colonial rule and the descendants of former slaves in the New World. Skin lightening agents have never been socially neutral; their use and effects have always been implicitly or explicitly political even if the people using them conceived only of their use in intensely personal terms. They were considered agents of increased social mobility and personal transformation to some, but instruments of subjugation to others.

In many parts of the world today, people with dark skin - regardless of their location or ethnicity - are considered inferior to those with light skin. Colourism is a type of skin colour bias that involves systematic discrimination against the relatively darkskinned within a particular group (Herring, Keith \& Horton, 2004; Hunter, 2007; Jones, 2000). Colourism has existed in many places for millennia because of the higher status accorded to people who could afford to spend their time indoors and lacked the darkened skin of those spending time outdoors. Colourism became more entrenched and institutionalised when people of visibly distinct skin colours lived in the same places and had offspring together. These conditions occurred widely in the Americas and the Caribbean during the centuries of the trans-Atlantic slave trade and during colonial and apartheid-era South Africa. Positive attitudes about lightened skin intensified in South Africa under the influence of people and ideas from the United States from the 1930s onward (Glenn, 2008; Thomas, 2012a), leading to a steady rise in colourism. As one could have predicted, the institution of the pass laws and apartheid ushered in a period of prodigious growth in the popularity of skin lightening preparations in the country. 
The commercial development of skin lighteners in the United States and South Africa

In social contexts of the United States and of other countries influenced by the colour consciousness of European colonialism, becoming lighter improved prospects for education and employment, social mobility, and marriage (Glenn, 2009; Hunter, 2005, 2007; Madrigal, 2006). In the United States, selective breeding towards whiteness was advanced as a long-term solution, but in the short term, many resorted to harsh chemicals to bleach their skin to more socially acceptable lightness (Jablonski, 2012). Development, production, and marketing of skin-bleaching products on a commercial scale began in the United States in the post-Reconstruction era, as segregationist "Jim Crow laws" restricted the opportunities and prospects of African Americans, especially in the South. By the mid-twentieth century, skin-bleaching products and practices began to have a significant sociological and economic impact on people and business in South Africa as well. With the installation and enforcement of apartheid in the 1950s and especially with the passage of the Coloured Labour Preference Act, which reserved certain jobs for people classified as "coloured", preference for people who could potentially pass as "coloured" became greater, and the popularity of skin-bleaching creams was not unexpected. Demand for skin lightening (and hair straightening) products seems to have been primed in earlier decades by the visits to South Africa by groups of missionary musical performers from the United States. Beginning at the turn of the twentieth century, these troupes (such as the Virginia Jubilee Singers) came to South Africa with a message of Christianised "racial uplift". With their talent and "smart and tidy" appearance including visibly straight hair and, in some cases, light skin, the performers became role models for South African modernity (Erlmann, 1991). Their performances in the major cities of South Africa in the 1890s were popular, and the fact that they were attended by influential South African political leaders like Paul Kruger (Erlmann, 1988) appeared to authorise their popularity with communities of South Africans of European ancestry. The net effect of their popularity for all South Africans was validation of their physical appearance and their Christian approach to entertainment.

\section{The rise of skin bleaching in South Africa}

The largest markets for skin lighteners have always developed in places where the social costs of darkness have been the greatest. Mercury-based skin bleaches were introduced into South Africa from the United States in the 1930s and became enormously popular, especially amongst people classified as "coloured" and "black". Skin lighteners were praised for "smoothening" the skin of the face, and for elevating the social status of both men and women. The company who 
manufactured skin bleaches in South Africa was the American-owned Apex Hair Inc., which was founded by Sara Washington in the 1930s to bring hair straightening products and skin bleaches to a mostly poor and working-class clientele. Apex emphasised use of products conducing to self-improvement and economic mobility (Thomas, 2009; Weinbaum, Thomas, Ramamurthy, Poiger, Dong \& Barlow, 2008). One of the ironies of the twentieth-century development of the skin-bleaching industry in South Africa was that it was connected strongly to African American entrepreneurship and the racialised role models that were common in the United States during the Jim Crow era.

During apartheid, black women in South Africa sometimes used skin bleaches to obtain jobs reserved for "coloured" women, but more often they parlayed a lighter appearance to enhance their prospects for engagement in social and employment settings that privileged light skin and a somewhat more European look. The unsightly skin blotches - sometimes denoting permanent damage to the skin that accompanied repeated use of skin lighteners were seen as positive evidence of being modern. Skin lighteners took away "the blackness". Darkly pigmented skin had become a disease in need of a cure.

It is impossible to know exactly how widely used skin bleaches were during the apartheid era, because many products were made by small companies and marketed locally. According to historian Lynn Thomas, however, skin lighteners had become so common in South African by the late 1960s that a 1969 survey showed that skin lightening creams were the fourth most commonly used household product after soap, tea, and tinned milk (Thomas, 2012b).

Thomas' studies of the history of use of skin bleaches in South Africa highlight the intersection of cosmetic technology, politics, and economics that lead to the increased popularity of lightening products during the apartheid years: "... the appeal and prevalence of these technologies of the self depended upon expansive political and economic structures that privileged light-coloured skin, made manufactured cosmetics widely available, and promoted their use through glossy magazines and local sales agents" (Thomas, 2009:203). The rise of some of South Africa's wealthiest and most influential industrialists, the Krok Brothers, was based on the coupling of modern production methods with clever packaging and ingenious advertising. The history of production and use of skin bleaches, and of opposition to the development and use of the products, demonstrates a dense interaction of racial hierarchies, capitalist commerce, and individual desires for betterment that parallel the American situation (Thomas, 2006, 2009, 2012b).

Opposition to skin bleaching in South Africa gained strength when anti-apartheid activists emphasised that lightening agents were loathsome products and should be avoided because they were harmful to health and to individual self-image. The 
"Black is Beautiful" campaigns of late twentieth-century South Africa probably had more long-term success in reducing the popularity of skin lighteners than those in the United States, because they combined social and medical information into comprehensive messages of personal empowerment and national pride (Thomas, 2012b). In 1990, South Africa became the first and only country in the world to prohibit advertisements for cosmetic products that made any claims to "bleaching", "lightening", or "whitening". Despite the combined action of social and medical activists, the market for skin lightening in South Africa has remained large, and cosmetics and skin-care companies have adapted their advertising vocabulary and ingredients in order to attract new users.

Skin lightening also receives boosts from the popularity of light-skinned celebrities whose images are widely circulated via social and conventional media and whose complexions are widely admired (Jablonski, 2011, 2012). Paradoxically, sales of skin lightening products increased in South Africa after 1994 because lighter skin and straighter hair were perceived as more modern and more professional (Jacobs, Levine, Abney \& Davids, 2016). It is far too simplistic to say that women (and the majority of consumers of skin lighteners are women) want to be white, but that retention of dark skin (and natural hair) reduces opportunities for professional training and advancement, and marriage prospects.

After mercury-based skin lighteners were banned in the United States in 1973, products containing hydroquinone or monobenzyle ether of hydroquinone became more popular there and in South Africa. However, mercurials were still considered the most efficacious, and illegal imports into South Africa of mercurial creams and soaps manufactured in Europe, Great Britain and Ireland persisted until the making of these products was finally discontinued in the early 2000s. Illegal products containing mercury and high percentages of hydroquinone can still be found in informal markets throughout South Africa, despite their illegality. When women can't afford to buy lighteners containing "safe" skin bleaches, they buy illegally imported hydroquinone-based products or resort to "under-the-counter", locally manufactured mercury-based compounds, often with disastrous effects (Davids, Van Wyk, Khumalo \& Jablonski, 2016).

South African and multinational companies have also been resourceful in extending their markets throughout sub-Saharan Africa. Selling hope has been easy when beauty, success, and happiness continue to be linked to lightness. Demand for skin lighteners is now high in African countries such as Nigeria, Ghana, Tanzania and Kenya with burgeoning economies and people eager to improve their status and prospects (Davids et al., 2016; Jablonski, 2012; Levine, Powell, Davids \& Jacobs, 2016; Street, Gaska, Lewis \& Wilson, 2015). Advertising has mostly targeted young women of marriageable age, but has been credited with helping to shift male preferences towards women with light-coloured skin. 
It is too simplistic to ascribe the use of skin lighteners to conformity under structural racism, because other motivations certainly enter into the complex personal decisions people are making about appearance (Jacobs et al., 2016). It is likely that people are making decisions based not only on perceived norms of physical attractiveness from the dominant world culture, but also on convenience, and because transformation of appearance relieves a level of psychological tension that they feel is generated in them when they interact with an unaltered appearance (Jablonski, 2011).

\section{Conclusion: The introduction of skin bleaches into South Africa was a genuine turning point}

The introduction of inexpensive products for transformation of physical appearance, especially of skin colour, towards more European-based norms in the mid-1950s was a significant turning point in South African history, because these products allowed people to personally negotiate and mitigate the psychological challenges of looking "too black". When a personal decision to use a product even a seemingly minor one affecting appearance - allows a person to feel more socially accepted and acceptable and affords them the possibility of enhanced personal financial gain through better employment or social associations, then the product and the decision-making process are elevated in historical importance. The promotion of skin lightening products in South Africa has been about selling the promise of a better appearance, leading to social elevation and happiness. For nearly a century, tens of thousands of South Africans have made personal decisions in front of their mirrors every day to lighten their skin, because they have felt that a lighter appearance would make them look better or would make their lives somehow easier. This is a dramatic, profound and tragic turn of events. 


\section{References}

Bonilla-Silva, E. \& Dietrich, D.R. 2009. The Latin Americanization of U.S. race relations: A new pigmentocracy. In: E.N. Glenn (ed.). Shades of Difference: Why Skin Color Matters. Stanford, CA: Stanford University Press.

Bonilla-Silva, E. \& Embrick, D.G. 2006. Black, honorary white, white: The future of race in the United States? In: D.L. Brunsma (ed.). Mixed Messages: Multiracial Identities in the "Color-Blind" Era. Boulder, CO: Lynne Rienner Publishing.

Broyard, B. 2007. One Drop. New York: Little, Brown and Company.

Davids, L.M.; Van Wyk, J.; Khumalo, N.P. \& Jablonski, N.G. 2016. The phenomenon of skin lightening: Is it right to be light? South African Journal of Science, 112(11/12). https://doi.org/10.17159/ sajs.2016/20160056

Erlmann, V. 1988. 'A feeling of prejudice'. Orpheus M. McAdoo and the Virginia Jubilee singers in South Africa 1890-1898. Journal of Southern African Studies, 14(3). https://doi. org/10.1080/03057078808708179

Erlmann, V. 1991. African Stars: Studies in Black South African Performance. Chicago, IL: University of Chicago Press.

Glenn, E.N. 2008. Yearning for lightness: Transnational circuits in the marketing and consumption of skin lighteners. Gender \& Society, 22(3). https://doi. org/10.1177/0891243208316089

Glenn, E.N. 2009. Consuming lightness: Segmented markets and global capital int he skin-whitening trade. In: E.N. Glenn (ed.). Shades of Difference: Why Skin Color Matters. Stanford, CA: Stanford University Press.

Golden, M. 2004. Don't Play in the Sun: One Woman's Journey Through the Color Complex. New York: Anchor Books.

Hall, R. 1995. The bleaching syndrome: African Americans' response to cultural domination vis-a-vis skin color. Journal of Black Studies, 26(2). https://doi. org/10.1177/002193479502600205

Herring, C.; Keith, V.M. \& Horton, H.D. (eds.). 2004. Skin/Deep: How Race and Complexion Matter in the "Color-Blind" Era. Urbana, IL: Institute for Research on Race and Public Policy and University of Illinois Press.

Hunter, M.L. 2002. "If you're light you're alright": Light skin color as social capital for women of color. Gender \& Society, 16(2). https://doi. org/10.1177/08912430222104895

Hunter, M.L. 2005. Race, Gender, and the Politics of Skin Tone. New York: Routledge.

Hunter, M.L. 2007. The persistent problem of colorism: Skin tone, status, and inequality. Sociology Compass, 1(1). https://doi. org/10.1111/j.1751-9020.2007.00006.x

Jablonski, N.G. 2011. Transforming "racial characteristics": Is it an appropriate role for aesthetic surgery? Aesthetic Surgery Journal, 31(3). https://doi. org/10.1177/1090820X11398113

Jablonski, N.G. 2012. Living Color: The Biological and Social Meaning of Skin Color. Berkeley, CA: University of California Press.

Jacobs, M.; Levine, S.; Abney, K. \& Davids, L. 2016. Fifty shades of African lightness: A bio-psychosocial review of the global phenomenon of skin lightening practices. Journal of Public Health in Africa, 7(2). https://doi.org/10.4081/jphia.2016.552

Jones, T. 2000. Shades of brown: The law of skin color. Duke Law Journal, 49. https:// doi.org/10.2307/1373052

Levine, S.; Powell, C.; Davids, L.M. \& Jacobs, M. 2016. Skin lightening/ bleaching. In: N.A. Naples, J.M. Ryan, R.C. Hoogland, M. Wickramasing \& W.C.A. Wong (eds.). The Wiley Blackwell Encyclopedia of Gender and Sexuality Studies. John Wiley \& Sons, Ltd. https:// doi.org/10.1002/9781118663219. wbegss 644 
Madrigal, L. 2006. The African slave trade and the Caribbean. Human Biology of AfroCaribbean Populations. Cambridge, MA: Cambridge University Press. https://doi. org/10.1017/CBO9780511542497

Norwood, K.J. \& Foreman, V.S. 2014. The ubiquitousness of colorism: Then and now. In: K.J. Norwood (ed.). Color Matters: Skin Tone Bias and the Myth of a Post-Racial America. New York: Routledge. https://doi. org/10.4324/9781315819334

Street, J.C.; Gaska, K.; Lewis, K.M. \& Wilson, M.L. 2015. Skin bleaching: A neglected form of injury and threat to global skin. African Safety Promotion, 12(1). https://hdl.handle.net/10520/EJC159577

Thomas, L.M. 2006. The modern girl and racial respectability in 1930s South Africa. The Journal of African History, 47(3). https://doi.org/10.1017/ S0021853706002131

Thomas, L.M. 2009. Skin lighteners in South Africa: Transnational entanglements and technologies of the self. In: E.N. Glenn (ed.). Shades of Difference: Why Skin Color Matters. Stanford, CA: Stanford University Press.
Thomas, L.M. 2012a. Imported Cosmetics and Colonial Crucibles: Pre-histories to the Twentieth-century Use of Commercial Skin Lighteners. Paper presented at the Wiser Seminar Series. University of the Witwatersrand, 23 July.

Thomas, L.M. 2012b. Skin lighteners, black consumers and Jewish entrepreneurs in South Africa. History Workshop Journal, 73(1). https://doi.org/10.1093/hwj/ dbr017

Turner, T.S. 2012. The social skin. $H A U$ : Journal of Ethnographic Theory, 2(2). https://doi.org/10.14318/hau2.2.026

Weinbaum, A.E.; Thomas, L.M.;

Ramamurthy, P.; Poiger, U.G.; Dong, M.Y. $\&$ Barlow, T.E. 2008. The modern girl around the world: Cosmetics advertising and the politics of race and style. In: A.E. Weinbaum, L.M. Thomas, P. Ramamurthy, U.G. Poiger, M.Y. Dong \& T.E. Barlow (eds.). The Modern Girl Around the World: Consumption, Modernity, and Globalization. Durham, NC: Duke University Press. https://doi. org/10.1215/9780822389194 

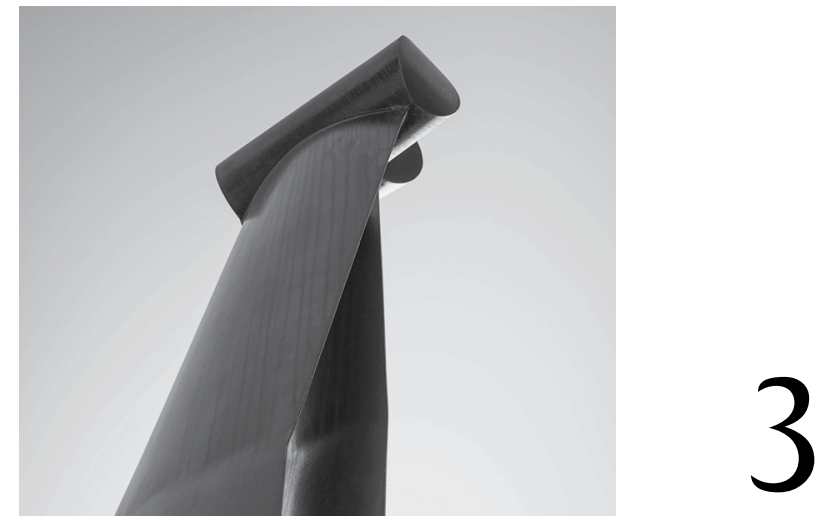

\title{
SETTLER-COLONIALISM, NATIONALISM AND GEOPOLITICAL POLITICS
}

\section{An overview of the mobilisation of race in South Africa in the context of lost turning points}

\author{
George Chaplin
}

\section{Introduction}

This chapter sets out to analyse turning points in their historical context and sequence in South Africa by considering large-scale global movements and how these turning points have shaped and influenced the development of racism in the country. All individuals are situated in a specific time and place, and this situated spatio-temporal context is not isolated or independent. Thus, all individuals are subject to modes of thought and practice that are embedded in geopolitics. The foreign influences that exerted pressures within South Africa are either related to broad-scale economic policy or to global political ideals. I will start with a brief review of the earliest history of South Africa and its contacts with colonial powers, then proceed to examine earlier mercantile and settler-colonial periods. Studying earlier history is important to show how it shaped more recent history. The focal point of interest in this chapter is race, racial attitudes and racial policy, because this work has been undertaken as part of the STIAS long-term project, Being Human 
Today: The Effects of Race. It is a truism to say that all political action is local and often very short-termed. I will not deal so much with local political responses or with the individuals that drove them. Rather, as a geographer, my focus is not the individual or a point in space or time, but how the situated place has an effect. This effect can be seen as autochthonous action or in terms of a wider geographic interchange. Both ideas are relevant to a history of South Africa. Being interested in global and long-term patterning of expressions of thought, I here look at colonial origin stories and statements of difference situated within a global rhetoric. This is not to say that any one side had a monolithic position. The Afrikaners were complex and nuanced and held many individual views - they had leaders of all persuasions, as noted by many South African historians, notably, Hermann Giliomee (2007). Complex and nuanced personal positions are often, however, reduced to the most simplistic rhetorical flourishes, for example, Mao's "The East is Red”. These can become self-sustaining memes which are then used by opponents as well as original proponents. Any discussion of racism in South Africa must ipso facto be primarily concerned with the period of European global expansionism. I end this chapter around the time of Kennedy's assassination in the middle of the twentieth century and the beginning of proxy war engagements. This was also a generation past the time of Nazism, when Nazi ideology had no appeal left except to the most marginalised and moribund. This time corresponds roughly with the Rivonia trial, the Sharpeville Massacre, and the rise of the armed wing of the ANC (African National Congress) Umkhonto we Sizwe and direct conflict in South Africa. At this time, we see the development of the late-stage apartheid repressive state in response to increasing pressures. My interests in this chapter are the strategic and global influences superimposed on South Africa rather than the internal political responses these influences generated. Recent history is the sum of historical and global influences, not just of individuals acting at any one time.

A turning point here is considered as an opportunity that was missed and that led to a particular racial consequence. The present is the very definition of lost turning points, so perhaps, these can be better thought of as missed imaginings. The nature of this kind of treatment - an examination of turning points - is basically a counterfactual one, which by their nature tend to be somewhat polemical. The view back in order to determine turning points must be done without historical hindsight-bias or judgemental hindsight. Because, although we now know the outcome of history, it does not follow that historical contemporaries should have been able to guess the outcome because they did not have the benefit of hindsight-bias. 


\section{Prehistory}

Modern humans in South Africa evolved in situ from prehistoric stock and clearly, the oldest residents, who are now the most isolated branch of humanity genetically, belong to the San group (Lachance et al., 2012). San people have resided in South Africa the longest and, therefore, have the clearest claim to land title. Overprinted on their genome, is that of the Khoekhoe, the cattle-herding people still living in the same area. These two groups have a history in the South of Africa far pre-dating any other. Because of the difficulty moving cattle into the Cape, due to its topography, ecology, and climate, the majority of the inhabitants of the Western Cape were San hunters rather than Khoekhoe herders.

Much later, people from West Africa arrived in South Africa. These people had first expanded into East Africa and then in two waves moved south. This movement was slow but relentless, being driven by demographic pressure. Direct evidence of these movements is not available in any historic texts, but they can be discovered through archaeological, genetic, and linguistic data (Lachance et al., 2012). The Southern expansion of Central African groups with darker skin into the territories of the lighter-skinned San and Khoekhoe was ongoing at the time that Europeans first interposed themselves on the Western Cape. This put the three different groups into inevitable demographic conflict. The Cape was sparsely settled, and diseases introduced by the Europeans, such as the outbreak of 1715 smallpox pandemic, soon depleted the indigenous population. It was never an empty land, but compared to overcrowded and resource-poor Holland, it might have seemed as such to the settlers. An empty land is a common settler delusion and one firmly incorporated in the Dutch origin story in South Africa.

\section{South Africa's strategic position}

South Africa has been subjected to all forms of foreign interventions primarily because of its vital strategic position. Located at the intersection of the Atlantic and Indian Oceans, it lies at the crossroads of the shortest and most easily navigated routes between the two largest and populous economic powerhouses of South, Southeast, and East Asia, and Europe. The alternative route around South America and across the Pacific was much longer and more difficult, being against global wind and ocean currents driven by the Earth's rotation. The Dutch first settled it as a refreshment station en route to the prosperous Far East. It was also very important in World War II for supplying British forces in North Africa when the Italian military made the Mediterranean too dangerous and military shipping cannot pass through the Suez Canal or the Red Sea at times of conflict. South Africa resumed 
in importance any time that the Suez Canal was threatened and again during the Korean and Vietnam Wars when large amount of war material was being shipped to the Far East from the American East Coast.

South Africa also has strategic importance because of its resources. The first of these was Khoekhoe cattle, other fresh food, and water for the extension of exploration and mercantile trade. The most obvious resource of South Africa was its vast wealth, notably its gold, which was important as a cornerstone of global monetary policy until the great crash of 1931. Until then, most of the world's currencies were reliant on the gold standard and South Africa controlled half of the world's gold production during those years. Other strategic resources were those needed for the support of military armaments, including chromium, cobalt, vanadium, antinomy, tungsten and, especially, uranium, because it was an early source of enrichable uranium for nuclear weaponry (Borstelmann, 1993; Noer, 1985; Thomson, 2008). Less strategically restricted to South Africa but also very important were sugar, iron ore, and coal. Control of these strategic resources and the general mineral wealth always put control of South Africa into a global not a local geopolitical framework, with dire results for South Africa's indigenous peoples. If South Africa had not been positioned at the major choke point of global trade, or if it had been devoid of important resources and great wealth, its history would have been more local, and the global community would have had little geopolitical interest in it. As it was, its strategic importance and wealth led to constant interference and these provided numerous potential times for turning points to develop.

\section{Race, racialism and racism in settler, colonial or nationalist South Africa}

Today, South Africa is still deeply racialised, a legacy from the period of apartheid. It was also deeply racialised in the past and this was a cause of apartheid in the first place. Today it is hard to speak of racism and racist ideology and imagine a period before the modern concept of race was developed (Jablonski, 2012). The earliest interactions within South Africa were not racist formulations at the time (Du Plessis, 1972; Theal, 1922), but in retrospect they can be seen darkly through a racial lens and were not prejudice free (Goldin, 1987).

The idea of settler-colonialism and the settler-state has become almost dogma in critical studies as it is here defined as:

The specific formation of colonialism in which people come to a land inhabited by (Indigenous) people and declare that land to be their new home. Settler-Colonialism is about the pursuit of land, not just labour or resources. Settler-Colonialism is a persistent societal structure, not just an historical event or origin story for a nation-state. Settler-Colonialism has meant 
genocide of indigenous peoples, the reconfiguring of Indigenous land into settler property. In the United States and other slave estates, it has also meant the theft of people from their homelands (in Africa) to become property of settlers to labour on stolen land.

(Rowe \& Tuck, 2016)

However, the term settler-colonialism encompasses many embedded ideas that are not synonymous. Settler-colonialism is at first sight a tautology, because any colony is, by definition, a settler establishment, but it is important to view these people as economic colonialists, not settler-colonialists. Economic colonialism is the imposition of projected power to extract wealth without the idea of necessarily taking the land or creating statehood. Imperialism is when a distant country projects its power without regard to the aspiration or welfare of the indigenous population. So, imperialism may or may not be concerned about extracting wealth, but imperialism does serve a strategic purpose. Modern colonialism or neo-colonialism is the achieving of the appropriation of resources without the actual imposition of imperial power or settlers.

\section{The first encounter with mercantile Europeans}

The Europeans came first as mercantile people looking for riches of the East and not those of Africa. They came by sea seeking an alternative to the land-based Silk Route of Asia. The global paradigm of this period of European expansionism was mercantilism, incorporating both economic colonialism and imperialism (Theal, 1922). The mercantile imperative, as a European right to expand around the world and plunder its riches, was seen by its contemporaries as a preordained or divine destiny. This idea is still dominant in the imperialism of Manifest Destiny in the settler rhetoric of the Americas. Another way of viewing mercantile imperialism is as the modern conception of "facts on the ground", and "We are here, so God must have wanted it". This is a modern interpretation of predestination that is particularly attractive to Calvinists, Evangelicals, and other twentieth-century imperialists. The expansion was not originally one of settler-colonialism although it was soon to follow (1922). The geopolitical background of the settler expansion of Europeans into the Cape was situated in the extensive wars of the period, be it the Thirty Years War, the Anglo-Dutch War, or the Seven Years War that was fought between the British and French. Refugees from European conflict settled wherever they could in both Africa and the Americas. They were driven by self-interest not national interest; they were refugees, settlers, or economic migrants. They were supported by the mercantile imperative to make profit but not driven by it. Human rights hardly existed as a concept at this time as this was the period of servitude, human ownership, the divine right of kings, and over-arching theocratic power. Settlers often incorporate divine status into their rhetoric to justify what would otherwise be seen as theft. The projection of power into South Africa at its first 
settling by Europeans should not be seen in the terms used by the National Party (NP) creation myth, as the Dutch founding of a promised land, but as a by-product of global politics (Du Toit, 1983).

Early ideas were not embedded in race, but in terms of religion, monetary worth and location

Mercantile attitudes towards indigenous peoples were not those of settlercolonialists. For mercantilists, people were seen as either worthy of investment or they were a resource to be co-opted. Race had little to no explanatory power at that time and indigenous people were seen in terms of utility (Jablonski, 2012). In South Africa, few people were enslaved, rather the local indigenous people were tolerated because they had cattle to trade. Slaves were brought into South Africa but many more came from the endpoints of Dutch mercantile interests in Batavia (Java) and India. Indigenous South Africans were widely enslaved only after potential trade with them had been exhausted and the European settler population had expanded enough to provide the Dutch East India Company (VOC) with victualing services previously supplied by indigenous cattle herders. However, most of the Cape's settler holdings were at that time small and poor, and European households often took but a single slave who lived with the family (Theal, 1922). Intermarriage, leading to interracial offspring, was quite common. To the early Dutch church, this led to fear of evil heathen influences. Non-Christians were seen as fit for conversion or as unworthy people by mercantile settlers, imperialists, and even by ex-slaves (Amponsah, 2013). All relationships at that time were thought of as a matter of religion and education, even though many settlers were little better educated than their slaves (Theal, 1922). The Huguenots and, a little later, German Protestants from the South of Germany joined the Cape settlers as new waves of reformation refugees. Many of the first Dutch settlers saw themselves as having been freed of Spanish subjugation and having escaped persecution in Europe. They did not see themselves as economic colonisers (1922).

To the upper class VOC, the indigenous inhabitants of South Africa were of little concern. The mercantile upper class, that is the privileged class, saw themselves as equally above the Dutch peasant as they were above the African indigenous peasants. Class tensions centred on taxes and control of the peasants living on nearsubsistence farming. Some of their number had been settled against their will as a form of press-gang employment. Some of these peasants slipped away from the tiny settlement around Table Mountain to be beyond the direct control of the VOC. These people were able to live amongst indigenous groups without undue hostility. However, this lack of central control led to efforts to return distant settlers to the confines of the defined VOC settlement (Theal, 1922). This was probably the 
first lost turning point: when poor Dutch escapees from the VOC lived within the confines of the indigenous population more or less peaceably. This potential for continued peaceful coexistence was soon lost. The VOC sought to estrange its lower classes from each other and passed laws about cohabitation. The VOC was exceedingly cruel in its treatment of errant slaves and other people considered property or without rights. Considering this, settler accounts of supposed indigenous barbarity, for example, a century later the stories about the Zulu chief, Dingaan, must be seen as self-serving. Lurid tales of heathen barbarism were used as a spur to develop separation of subsistence classes and to incite racism. They were eventually used as a justification for the destruction of indigenous peoples.

Dutch tales of settler origin emphasise interracial strife. The Battle of Great Fish River of 1770 was a result of demographic conflict with indigenous peoples that was given great emphasis. Forever more, the Dutch would frame their interactions with the indigenous population in terms of celebrated conflicts. The Dutch church increased its antagonism towards indigenous Africans and strengthened its hold on the Dutch population. Church was used as an early unifying concept from historical contingency by European theocracies. Native position within the church was not straight forward. Some slaves willingly converted, only to be rejected by the church later. The interactions between locals and settlers were not monolithically adversarial and sometimes peaceful coexistences lasted for a while; there were numerous struggles, especially with groups living in more fertile areas of the coastal plain to the north (Ross, 2013). Any mention of support and trade with locals was replaced with ever more strident tones of conflict. The settlers' origin stories lionised the settler and either denigrated Africans or sometimes portrayed them as fierce but vanquished opponents. Either way, the settlers sought to further their own settler-hero myth.

\section{Dutch identity emerges in reaction to British economic colonialism}

British colonialism in South Africa came as result of French attacks in India in the context of the Napoleonic wars. Their initial imperative was global, strategic, and imperial. It sought to protect the route to the British Indian Empire from hostile Dutch allies of Bonaparte, and thereby weaken French colonies in India. By the time the British settlers annexed the Cape, the Dutch had resided there for almost 150 years. The philosophical attitude of English economic colonisers differed from the earlier Dutch settlers. Theirs was more exploitative and aimed at enriching the home country, not the profits of mercantile agents. They were not there to steal land as property to live on, as much as to steal what the land had to offer and to take it home (Thomson, 2008). The colonies were either customers (particularly for manufactured goods as in India), or a source of raw materials. Slavery soon 
ended after the Napoleonic war in the British colonies and South Africa. South Africa was never a major supplier of chattel slaves. However, the threat of slave emancipation was seen as a threat to the Dutch settlers that relied on slave help on their small holdings, although NP narratives denied this as a source of grievance. The British mishandling of compensation from the emancipation of Dutch chattel or property slaves was enough to cause widespread financial hardship for the Dutch settler community. The declaration of Piet Retief at Grahamstown showed that dissatisfaction with the English rule cemented ideals of South African Dutch nationals as a separate identity, an ideal identity that would soon strengthen its hold.

After the Peace of Westphalia, there emerged the definition of nationhood as being an ethnic idea, not just one of territory. In the early nineteenth century, this was expanded to include a linguistic element to the previous ethnic definition of nationhood. This Westphalian linguistic-ethnic conception of nation acquired a cultural aspect too. This complex Westphalian political conception gave rise to a new form of nationalism that was driven by the new and complex interaction of developing ideas of statehood and personal identity. The popularity of this new mode of national identity was foundational to Afrikaner aspirations to escape from British control. The dissatisfaction with the English colonialists, their financial impositions, the introduction of new and more favoured British settlers, and the financial mishandling of emancipation, led to The Great Trek. The move into the interior brought another round of conflict with more indigenous Africans. The Cape Dutch again saw their plight as that of a subjugated people united by language, culture, and church. They were being assailed by a foreign power and faced strong opposition by indigenous peoples they saw as heathens.

Race was now paramount and would become ever more important as Voortrekkers faced stiff opposition from more powerful indigenous polities they encountered as they moved north. These polities were more centrally organised than the decimated Khoekhoe and San people indigenous of the far Southern Cape. The concept of race had been created in support of chattel slavery and mercantile profit (Jablonski, 2012). By the time of the Battle of Blood River of 1836, a discourse of race, power and specialness had been incorporated into both Dutch origin stories and was deeply into their zeitgeist. Blood River was another monumental conflict to be celebrated like Fish River. The Dutch were followed and displaced by ever more rapacious English colonisers, being driven out of Natal first, and then with the discovery of vast wealth in the Rand, driven out of almost everywhere else in Southern Africa that had value. They mostly became a marginalised and impoverished group. 


\section{Modern imperialistic capitalism and colonialism}

British globalised colonialism came to South Africa late and left early, but became immensely rich in that interval. British colonialism was not particularly important to the development of apartheid racism. The British behaved in South Africa as they did elsewhere, more as the classic economic colonialist force subverting local position and indigenous rights, serving commercial interests, enriching the home country, and projecting widespread paternalistic racism. Settlement was slow, small, and relentless but with the discovery of immense wealth, British policies became greedier and more self-benefitting. Poor white farming Boers were viewed as little different from indigenous populations and were often treated with the same paternalistic policies and attitudes.

The tendency by both Dutch and British, was to encourage tribalisation within the indigenous populations in an effort to divide and conquer. These multiple ethnic groups were as threatened as the Boer Republics were by the discovery of gold. However, the native groups were too disorganised and mutually antagonistic to prevent prospector incursions, and race separatism prevented a combined front being developed between indigenous groups and Boer farmers in the Republics. Race again emerges as the factor that defined a turning point that could have seen a common cause - the fight against British colonialism. This catastrophe had been predicted by Kruger who saw that the draw of gold would displace both the indigenous people and local settler-colonial population. Gold-fevered newcomers had repeatedly overrun the United States and Australia, disregarding previous legal or emotional titles to the land (Dubow, 2010).

In 1881, the tensions between abusive British colonists and Dutch settlers brewed into the Majuba Massacre. This became another monumental marker in Dutch origin stories of independence and separateness centred around national identity of the kind of non-racially based nationalism that emerged from Westphalian conceptions of statehood centred around language, ethnic, religious, and cultural separateness. The Afrikaners, in their self-declared Republics, felt encircled by (poorly-treated and hence hostile) indigenous Africans and, further, both Afrikaners and indigenous Africans were subjected to the caprice of rapacious British Outlanders. A potential for these two beleaguered groups to unite against the Outlanders was never realised and must be viewed as another lost turning point.

\section{Dutch settlers cement the concept of Afrikaners}

It is around this time that the Dutch settlers transformed into Afrikaners, named after Afrikaans, the creole language that had been created in South Africa from Dutch and many other languages into a unique indigenous language. The Afrikaner 
identity emerged from local cohesiveness and a feeling of final separation from the source country. The British replacement of Dutch mercantile power structures brought about the cutting of any remaining ties to a Dutch homeland except those to the Dutch Church. Most memories of Holland and European history were lost since Britain had severed Dutch settlers' ties to Holland for generations. Ties to Holland were always less strong because of the nature of the original settlement being founded by economic migrants and refugees and not being a government sponsored settler-colonialist state. Transport to Europe was long, costly, and dangerous, so much so that Dutch and Huguenot smallholders were unlikely ever to return to Europe from the start. The clergy, military, and the mercantile officers regularly returned but most Dutch could not. Dutch farmers in South Africa had become increasingly poor. As they multiplied and came under pressure from the British, they moved to more marginal land, smaller plots, or were driven off the land into desperate poverty in cities. Poor Afrikaner whites were an especially embittered class.

The Afrikaner never wished for a New Holland, in the same way as the English with their New England, and they never dreamed of returning to idealised homeland like "Ol' Blighty" as did the English colonisers. The Afrikaners saw themselves as a people forged in South Africa. From around this time, they invoked an autochthonous agency of their adopted home. Their homeland made them special. This I would say marked a developing indigeneity to the Afrikaner identity that earlier the South African Dutch and colonial English certainly never had.

These developments left the Afrikaner with an inward looking and insular world view (Thomson, 2008). Afrikaners felt that they had Africa or nowhere. It is interesting that, a little later, Boer War prisoners would complain about being taken overseas as being cruel punishment because they were people of the land. This was a strange statement considering the Dutch were the most far-reaching maritime nation in the mercantile world. This shows the strength of Afrikaner belief in autochthonous agency.

\section{The British seek to crush emerging Afrikaner identity}

The Anglo-Dutch or Boer War, and the Second South African War, or as it was called by nationalists, the War of Liberation, finished forging Afrikaner identity and led to a much stronger hatred of the British. When the Boers rebelled, they felt the full draconian force of British imperial displeasure and were treated abominably. Although the British were somewhat magnanimous in victory, the potential for an enduring peace was squandered. The British in a display of petty pique further pushed Boers into militant Afrikanerdom. Governor Alfred Milner was determined to abolish Afrikaans language and culture and thereby destroy incipient feelings of 
nationalism by forcing the Boers to speak English. This was a move the Afrikaners stubbornly resisted. This attempt to destroy Afrikaner culture only strengthened the group's sense of isolation because no global power had come to their aid during the Boer War (except for minor input from Russia and Germany who were imperial foes of Britain). In the massive rebuilding that was necessary from the wartime scorched-earth policies of the British imperialist army, indigenous Africans were left out. More than 26000 Boer women and children died in British camps, promoting another rallying cry for nationhood. The 13000 Africans who died were forgotten. Another turning point for racial and national unity had been lost.

The last gasp of colonial intervention in South Africa was that of Germany supporting Afrikaner aspirations and funding resistance towards the British in the early twentieth century. The 1914 outbreak of World War I was seen as a chance to reconstitute the Boer Republics (Bunting, 1964). The simmering hatred of British excesses of the Boer War and Milnerism were fertile ground for mobilisation and some Boers rose up. This led to a mini-civil war between Afrikaner polities that were forcibly put down by Boer War hero Jan Smuts and others in favour of the British. The Afrikaner nationalists were again crushed. In response to Nationhood in Australia and Dominion in Canada, South Africa was soon to become a Commonwealth nation with weakened colonial control. This lessened political control was not enough to ease nationalistic demands and was not accompanied by economic freedom from Britain.

The position of the British elite was particularly patronising and driven by profit. Ideas of colonial power and responsibility played out alongside the tired old trope of "the White man's burden". This, as the labour force was used to extract gold at maximum profit from British-owned mines at hardly sustainable wages. The mineworkers were intentionally split along racial lines, on the excuse that they would be dominated by what they insultingly termed "kaffirboeties" (black-friendly whites) - mostly newly imported British miners - followed by the communists who would take advantage of the African workers (Bunting, 1964:274-278). In discussing groups here, I use the terms "black" and "white" as they are still widely used in South Africa, but it must be recognised that these are not neutral terms and are not useful designators of diverse polities.

The early twentieth century saw the spread and mobilisation of racial policies to marginalise indigenous workers to provide cheap labour for increasingly expensive mine operations. South African gold is plentiful, but it is derived from low-grade ore and is expensive to extract. Government policies were instituted that prevented blacks from acquiring land, and included the introduction of pass laws and other excesses. This increasing repression saw a turn from earlier, more passive forms of native representation to ever more radicalised interactions with the government. 


\section{Complex interplay between groups of the South African population}

There has never been a monolithic political movement in South Africa. The British were the closest with their pattern of globalised capitalist colonialism. After the Second Anglo-Dutch War, the Afrikaner polity was split into two blocks, those who hated the British and those who got tired of fighting them, the accommodators. After the British effectively left completely by the 1931 Statute of Westminster, the two blocks politically fought for control (Gibbs, 1950). The accommodators had a brief respite at the outbreak of World War II, but when austerity-ridden, post-war Britain withdrew its influence, hard-core nationalists rose to power. These conservative ethno-religiously defined politicians were the ones to instigate and develop the apartheid state. The different divisions of the Dutch Church also had different attitudes to World War II and to relations with Nazi-influenced organisations (Van Tonder, 2013).

The African indigenous populations were also divided between two modern global political movements, democratic capitalism and communism. They also had struggles between traditional power structures, and modern progressive attitudes based on appeals to universal humanist values. Native African nationalist movements started around 1882 (Lerumo, 1980:26), but did not unify as a single voice on the world stage in opposition to colonial exploitation, entrenched racism, or later, to the emergence of apartheid.

\section{Anti-British elements seek theories and allies on the global stage}

In answer to wars with the British, Afrikaners felt the same crushed desperation of the colonised as did the other indigenous African people. In the 1920s, radical elements of anti-British Afrikaners sought allies to thwart British imperialism. Therefore, they sought support from traditional British antagonists, such as Germany, German South-West Africa (GSWA) and Russia. Soon after the Congress of the Comintern in 1919, most nationalists became wary of international Marxism and turned back to newly re-emergent Germany. Hitler's implementation of a state composed of people sharing a common language without heed to existing national boundaries - in his case, greater Germany - appealed greatly:

Hitler's Mein Kampf shows the way to greatness - the path of South Africa. Hitler gave the Germans a calling. He gave them a fanaticism which causes them to stand back for no one. We must follow his example because only by such holy fanaticism can the Afrikaner nation achieve its calling.

(Rev. J.D. Vorster, 15 September 1940 to Students meeting at Groot Schuur from Vatcher, 1965:63) 
The Afrikaners saw in national socialism a fairer capitalist economic model that eschewed the hegemony of big business and bankers - British rather than Jewish in this case - and promoted a privileged middle class (of Afrikaners) without needing to extend egalitarianism towards non-whites. Even a few black African leaders spoke in favour of the Nazis (Vinson, 2012:201, note 139). In seeking to throw off British domination, they were still effectively engaged in a century-long decolonialist struggle.

\section{Early communism}

Communism appealed to many nationalist Afrikaners who resented capitalisticcolonialism. They spoke admiringly of the Bolshevik revolution (Bunting, 1964:36-37). Poor whites were particularly drawn to Bolshevism: Dr D.F. Malan wrote in 1919, "The Bolsheviks stand for freedom like the Nationalist party" (Lerumo, 1980:50).

The British exported a militant trade union attitude through visits to South Africa of United Kingdom Labour Party representatives like Kier Hardie and Lloyd George. In earlier labour struggles, white miners and workers were often organised around broadly socialist principles. As early as 1907, communist influence was apparent and this was further emboldened by the 1917 revolution (Lerumo, 1980). Labour activist David Ivon Jones, who invoked the communist cause (ibid.), was considered by conservative NP members as traitorous, libellous, and with a diabolical stance that eschewed the Church. He attended the third Comintern in 1921 under the international socialist league (ibid.:42). By 1928, the Communist Party was predominantly black, but its leadership was still almost completely white (ibid.:57). The communist movement was to become permanently split, partly over race and partly over ideology. The Afrikaner partly rejected Marxism because it was, first, led by British and English speakers; second, because it was foreign; third, it was against national identities (internationalism); and fourth, because it stood for racial equality amongst workers.

Kier Hardie had noted earlier that unfair work practices would lead to socialism rising in the native workforce. Labour practices, in general, supported racism at both the management and the interpersonal levels, and racism was used to further keep the workforce from uniting in the face of personal and institutional prejudice (Cox, 2000; Goldin, 1987).

With the founding of the South African Communist Party (SACP) by D.I. Jones and S.P. Bunting, the race issue was not important because class struggle was paramount (Limb, 2010:59). The most contentious issue on the part of the ANC was reaction to the pass laws. These laws were part of an effort to make labour cheap and were used to prevent urbanisation, and had the effect of preventing 
black education. They also benefitted privileged white interests by preventing black collectivism and mass mobilisation. The ANC moved very slowly into the arms of the communists. For example, Josiah Gumede was invited and attended the ceremonies in Russia in November 1927 for the tenth anniversary of the Bolshevik Revolution. Although essentially non-communist, he saw the need for help in the face of a pitiful response from white intellectuals and local and colonial government officials to racial and class inequalities. Both the imperialists and the capitalists saw no unity with a class struggle of black workers. There was a common notion of "Bantu Egalitarianism" and that they were essentially communists by historical nature. Nationalistic tendencies in the ANC even identified with the Hertzog government in seeing the need to escape British and international predatory capitalism. This potential alliance was thwarted by intransigent racism on the Afrikaner side (Limb, 2010:251). Racism also led to denigration of native causes with calls within communist ranks not to pander to the petit bourgeois of native nationalists with their traditionalist power structures. This must be recognised as another chance of sounding a common message of racial unity in class struggle being either lost or purposely destroyed (ibid.:378).

The removal of the Cape Franchise in 1936 was another effort to emasculate critics. The tide was turning against the black workers and the ANC had lost some of its organising strength (Limb, 2010). The communists in the black effort had some support from the peasant movement and more particularly from the trade union movement. This was epitomised by the garment workers and their racially integrated action who were led by the Jewish leader, Solly E.S. Sachs. This was another propaganda opportunity for the National Party, which took on ever more of the German national socialist tropes of subjugation by both Jewish Bolshevism and Jewish capitalism (however much these two economic theories seem mutually exclusive today) (Bunting, 1964; Goldin, 1987).

Strikers frequently sought support from their black co-workers and would induce them to strike with them. The trade unionists were less racially divided at the start of their movement and were influenced by white labour struggles common then in Europe. This support was despite the fact that white workers were striking to keep a sevenfold advantage over black wage structure (Krikler, 2005). The use of the red flag in a march brought harsh criticism from nationalists and, by the time of the ascendency of the nationalists in the 1930s, most white workers were toeing the Afrikaner party line. In South Africa, race was a wedge issue that the nationalists used to divide organised labour into weaker racial groupings to the detriment of everyone except the capitalists and poor whites. The connection of labour movements and the black egalitarian struggle was permanently broken along racial lines by the scramble to protect jobs in light of the 1930s depression (Limb, 2010) 
because poor whites sought to protect themselves at the expense of their African colleagues. The association with the African nationalists and communists arose quite early, from the desire to produce a united front against Afrikaner nationalists and their racism, but contacts between the ANC and SACP/CPSA vacillated from being close, with the two organisations having shared officers, to attempts by the two organisations to distance themselves from one another.

\section{Afrikaner nationalism looks to Europe}

Any admiration of communism was soon abandoned by Afrikaner nationalist elements because international socialism seemed a threat to the ethno-linguisticreligious national identity the Afrikaners had established for themselves. They were particularly worried by the atheistic tenets international communism espoused. Other international movements like Garveyism and Pan Africanism incited fear too (Vinson, 2012). The newer doctrine of national socialism seen in Italy and then Germany seemed much more tempting because fascism still accommodated privilege. The temptation to replace British privilege with Afrikaner privilege was irresistible. This process saw the continuous denigration of indigenous black populations and was unfortunately triumphant over any movement towards egalitarianism. The earlier British excesses made fascism and national socialism popular with a faction of Afrikaners because it was also seen as anti-British (Italy and Germany being stridently anti-British at the time) and by far preferable to non-nationalistic and atheistic international socialism. The tough ideals of the Nazis were just as seductive to Afrikaners as they were to English, Europeans, Americans, or the Japanese in the 1930s. It is important not to project back onto that time from what we now know. Then, no contemporary expected Hitler would murder millions of people in mechanised death camps. The overarching association of Hitler's Nazism with the holocaust in the minds of most people today makes labelling something "Nazi" a severe insult. This was not so in the 1930s and really not until the horrors of Belsen or Dachau were seen on public newsreels. At the height of Nazi propaganda, there was no hindsight available to question the apparent social and economic success of the Nazis. Similarly, their military achievements seemed unstoppable until 1942 with El Alamein and Stalingrad. A large South African troop presence was deployed in El Alamein, making the vulnerability of the Nazis keenly felt.

\section{Post-World War I social experiments in Europe}

The acceptance of a role for Nazi policy in the politics of South Africa is still very strongly disputed by some South African scholars, for example, Hermann Giliomee. However, much of this is retrospective in as far as they now know the 
outcome of the Nazi experiment. At the start of the War, even the Giliomee family were strongly pro-German (Giliomee, 2016). This is not surprising or particularly controversial because when national socialist ideology was being developed, it was globally very popular. In its earlier days prior to German aggression, virtually all developed countries either flirted with it, for example, Oswald Moseley in the United Kingdom and The German American Bund in the United States, or they adopted it directly, like the Axis powers, Germany, Austria, Italy, Japan, and their sympathisers Spain or Portugal. Consequently, many similarities between the ideas of national socialism about self-determination in terms of cultural, ethnic, religious, and racial nationalism coalesced into the conception of Volksgemeinschaft. This same development was echoed in the Dutch community of South Africa in relation to perceived threats from English colonialists, and indigenous Africans social pressures.

Recently, strident arguments about Nazi influence have centred around Eugen Fischer's influence in Stellenbosch University (Robins, 2016:273-274), but arguments about Nazi influence have been long and vociferous (Dubow, 1995, 2015; Duffy, 2006; Durham \& Power, 2010; Furlong, 2003, 2005, 2010; Giliomee, 2000, 2003a, 2003b, 2008, 2012; Grundlingh, 1990). Most of these are not from an historical political perspective but are post hoc arguments, insults and defences against same in light of post-war knowledge of outcomes. Only a few individuals have continued to mobilise Nazi Volkish sentiments and these are tiny fringe movements are devoid of political power. I believe this remains true even considering white-privilege protectionism and the very recent revival of rightwing extremism.

I am not here suggesting that apartheid is comparable with our post-war understanding of Nazi ideology and action. The Afrikaners with their strong religious attitude and divided ranks would have never considered genocide. It happened in the German occupied territories, because they were isolated by war. In a post-war globalised environment, black genocide was unthinkable, because it would have led to a massive native uprising in the manner imagined by Fanon $(1963,2008)$. The backlash would have led to an almost certain punitive international intervention.

The connections to Nazism are in its political conceptions and underlying philosophies. The retreat of South African nationalists from the Germans and Nazis followed soon after the first military failures of the Germans threw the future of the movement into doubt (Gibbs, 1950). The public denial of Nazi influence started before the end of World War II but by its end, and especially during the Nuremberg War Trials, when evidence of mass atrocities became widely known, any public support was silenced (Gibbs, 1950; Sparks, 1990). This did not stop wide-scale 
pardoning of Nazi war agents and sympathisers in South Africa, though. The desire to distance oneself from Nazi theory is understandable today. No one, not even Germans, wants to be associated with Hitler, despite the massive support the Nazis once had in some segments of German society (Childers, 1984; Fritz, 1987). However, in private, stalwart pro-Nazi elements in South Africa like Oswald Pirow - who was considered by the British and Americans as leader of the pro-Nazi wing of Malan's National Party - were still seeking alliance with the British fascist leader Mosley (The Security Service, 2012). In this document, he is quoted as referring to the accused as the "Martyrs of Nuremberg" (The Security Service, 2012).

Nazi theory centred on concepts common to South Africa and other racist settlercolonial states. Nazi propaganda was popular and many South Africans were pro-German even if Nazi theories were not widely discussed. This was to change after the war.

During the Second World War, the entire family was pro-German. Neighbours congregated at Grasberg to listen to the broadcasts of Zeesen, the pro-German short-wave radio station. One of my first political memories is of my disappointment at reading in the paper in 1945 that Germany had surrendered. I cannot recall, however, that the Nazi ideology or even Adolf Hitler was ever discussed. When the horrors of the Holocaust became known later, it was a great shock to the family.

(Giliomee, 2016:6)

One overriding concern was that of racial hygiene (Bunting, 1964:97; Childers, 1984; Dubow, 1992, 1995, 2010). This was to be achieved by the spatial arrangement of races (separateness and deportation or living space), and prevention of interracial marriage (Childers, 1984; Klausen, 2002). The races were to have separate and disparate education objectives, including low-level technical education for racially inferior menial workers, as specified in Banting Education Act (Bunting, 1964:206). Under the Nazi regime, Eastern Europeans were the racially inferior, serving the culturally, intellectually, educationally superior paternal population. This policy, as formulated by Rosenberg, Himmler, and Goebbels, sought to restrict education to the minimum necessary to maintain an illiterate agrarian work force, and a barely literate (8th grade level) but technically competent cohort of factory workers, who would be supervised closely by German managerial staff (Childers, 1984). In South Africa, science and education was generally only for the benefit of State and Church, and both State and teacher came before family (Bunting, 1964). Max Eiselen, the first minister of apartheid education, was trained in Nazi classificatory techniques and put forth the policy of education for inferiority (Sparks, 1990:195; but see Robins, 2016). By 1941, the nationalists were openly discussing the Boer Race (Sparks, 1990:42) and Prof. Geoff Cronjé was talking of religious race-determination (Bunting, 1964:97). Due to the strong influence of the Dutch Church (Giliomee, 2003b; Ritner, 1967), 
Nazi-style eugenics was not adopted in South Africa as it had been in segregationist America or Germany (Larson, 1995). Other ideas such as the anti-materialism and anti-individualism of early Nazi thought, strongly appealed to the NP with their ideal of the selfless Boer (Noer, 1985:44). The idea that a nation was its people resonated too (ibid.:12). The Dutch Reformed Church certainly was not itself directly Nazi inspired. Afrikaner support for Nazi ideas was nuanced and, in many cases, unspoken (see, for example, Giliomee, 2003a). This position is not accepted by critics such as Patrick Furlong. Whether by direct influence or indirectly from similarity of cultural roots, there was a strong affinity to ideas and fears about democracy and racial impurity. These movements were not generated only within South Africa: They were world cultural memes driven by anxiety about the end of the Old World order of colonialism and Eurocentric hegemony after World War I.

The ideal of the worker was unusual in national socialist Germany. The unions were seen as a danger to Weimar Germany because they were thought to be controlled by international communists. So, Hitler nationalised them, and reduced them to single, non-competing workers' representatives with sole responsibility to the Nazi state. The same idea that was called for in 1941 South Africa (Bunting, 1964:262). The call for oaths of loyalty was another policy area that resonated both within party members and non-party members. The South African press controls called for in 1937 were ostensibly to prevent press insults of Nazi leadership (1964:228). The nationalists shared Hitler's fear of a free press. Democracy by a purposely uneducated and unsophisticated majority was derided, although hints at the need for a dictatorship soon quieted with Hitler's defeat. Equal rights were equated to communism (ibid.:162) and against party doctrine because it would lead to full integration of populations. The fear of native representation was exacerbated by having been spurred on by global rhetoric of the Atlantic Charter and Russian encouragement of colonial self-determination.

The craze for racial typing was widespread since the end of the nineteenth century. The nationalists identified a clear connection between the Dutch and NordicAlpine Germanic race types. In the late nineteenth century, Europe there had developed racial ideas that elevated Aryan or Nordic people as a special creation, genetically unique, and claimed them to be the pinnacle of development (Chamberlain, 1911; De Gobineau, 2000). Ideas of racial purity and nationalism were soon amalgamated to give rise to a potent quasi-biological, lingo-nationalist, with white-supremacist tendencies. These would become the foundational philosophies of fascist regimes in the second quarter of the twentieth century. These policies first saw their dreadful potential enacted in present day Namibia, or as it was then, German South-West Africa (GSWA). There, 70\% of the indigenous people were killed in battle, murdered, or incarcerated in atrocious conditions 
or left to die of exposure on cold and damp Shark Island. This genocide was a rehearsal for lebensraum, wide-scale enrichment through ethnic-based theft, and military-scale murder, all common to the solution seen in occupied Poland and Government General to the east. GSWA was to have extensive influence on Nazi attitudes and policies through Hermann Goering, whose father was administrator there (Sowden, 1944). The fact that segregationist attitudes in South Africa predate Hitler, does not falsify a Nazi commonality. Concerns over racial purity and fear of mixed marriage spring from a common eugenicist theory developed in Europe, America, and South Africa (Larson, 1995). Jim Crow laws in the American South grew in part from the same influences that Nazi philosophy did (Bernasconi \& Lott, 2000; Chamberlain, 1911; de Gobineau, 2000) and eugenics (Larson, 1995). Further evidence of the increase in Nazi influence can be seen in rising AntiSemitism in the 1930s and tropes of Jewish capitalism that led Dietrich Bonhoeffer to call for Jewish boycott in South Africa (Robins, 2016:32) were definitely developed and borrowed from Nazi propaganda, as was the distribution of the forged Protocols of the Learned Elders of the Priory of Zion (Bunting, 1964:63). Anti-Semitism rose considerably in the 1930s (Bentwich, 1942; Shain, 2017). The Anti-Semitist's policy sought to prevent Jewish and Southern Europeans from emigrating to South Africa. These were formalised in immigration quotas in 1930 and the Alien Act 1937 closed the door to the plight of German Jewry (Gilbert, 2010; Shain, 2017; Sowden, 1944). The Nazi espousal of racio-ethnic group-think eschewed individualism. This was a suitable model for the Afrikaner where the group was centred on Dutch Reformed Church (Thomson, 2008).

An ideology of racial specialness, power, will, and ethno-cultural-linguistic and religious exclusivity, can be shaped to serve almost any purpose. In the twentieth century, it was mostly used to enrich the power-holders. The emerging new bourgeois and petit bourgeois saw themselves as rightful heirs to the wealth of the disintegrating aristocracies all over Europe. In South Africa, they saw national socialism as being centred on their own interest because this was not the socialism of Marxism (Borstelmann, 1993). The strong paternalistic governmental framework favoured by national socialists resonated with a large fraction of Afrikaners, and further interest was fanned by British indifference, maltreatment, and excesses. There was also an unreasonable attachment to the grievances of dead generations, as few peoples are as guided by a sense of their past as Afrikaners (Thomson, 2008). Future nationalist leaders such as J.G. Strijdom, H.F. Verwoerd, and B.J. Vorster all supported Nazism openly well into the 1940s (Harrison, 1982; Thomson, 2008). Oswald Pirow, the defence minister, personally met with Salazar, Franco and Hitler in 1937 (Sparks, 1990:172). Increasingly from 1929 onwards, fears of racial defilement from mixed marriage leading to a weakening of Afrikaner strength and 
vitality, were seen in the terms of racial purity formulated by Rosenberg, Himmler, Hitler and the Nazi elite. Influential men in this formulation were Nazi convert and German-educated Dr Piet Meyer, along with Dr Hendrik Verwoerd, Dr Nico Diederichs, Prof. Geoff Cronjé, Dr Daniel Malan, and the ferociously anti-British Dr Albert Hertzog (Citino, 1991; Gibbs, 1950). By 1944, a committee of the FAK (Federasie van Afrikaanse Kultuurvereniginge) concluded that any move towards egalitarianism between blacks and whites would be race suicide (Harrison, 1982).

The appeal of national socialism and fascism was not universal. This is exemplified by the strident contrast of apartheid leader Dr Daniel Malan to his family member, the Allied war ace, Sailor Malan, who was proudly pictured with his black Caribbean fellow flying ace. These tensions could have led to another Afrikaner civil war. This was narrowly avoided in early 1939 when Smuts' group took control, supported by pro-English Afrikaners and English South Africans. This was fomented by his sending of armed police to pacify the Nazified and militarised police in GSWA, which was still a League of Nations mandated territory of South Africa. GSWA had been organised into a strong Nazi camp encouraged by common identity, anger at Versailles Treaty based mandates and impoverishment, need for German strategic sea lanes, and support of regional Nazi espionage capabilities (Wilkins \& Strydom, 1979). It had instituted a NASDP Party organisation, and the Hitler Youth, wide scale indoctrination and a call for reunification with Germany as soon as Hitler came to power in 1932. It also maintained a strong anti-Semitic posture. This led the South African mandate to formally ban both the NASDP (Nazi Party) and the Hitler Youth in GSWA during 1934. Despite this, Hitlerisation or Nazification of GSWA was complete in 1939 with a large contingent volunteering for Wehrmacht service (Sowden, 1944). Although Hitler often espoused respect for Britain and its Empire, he always demanded the return of former German African colonies, foremost being GSWA (Hofmeyr, 1939). There were clear designs too on South Africa's strategic materials and especially its gold because Nazi expansion had nearly bankrupted German foreign reserves. The timely intervention of Smuts was decried by Hertzog and Malan (Gibbs, 1950). Malan identified so closely with the Nazi cause that he termed himself Volksleierin during the election of July 1943 (Sowden, 1944). The Portuguese colonies of Angola and Mozambique were another fascist influence upon South Africa. Although the Portuguese dictator Salazar was not a pure Nazi, he was a pseudo-Nazi like his neighbour, Franco. Salazar differed in that his racist formulation was more reminiscent of the ideology of mercantilism with the strong support of Catholicism. He and Franco were models for a theocratic interpretation of Nazi racial supremacy that the Malan fraction could adapt (Bloomberg \& Dubow, 1990). Mozambican waters were a haven for Indian Ocean activities of the Kriegsmarine, during World War II and spies were run out of Lourenço Marques (Fedorowich, 2005; Furlong, 
2005; Sowden, 1944; Sparks, 1990; Vinson, 2012). One of these spies was said to convey messages directly to Dr Malan from Third Reich foreign minister, Von Ribbentrop, but Malan was not the most extreme of the pro-Nazi factions: that honour went to Dr Oswald Pirow and his New Order Party (Bunting, 1964:89). Another direct message to the paramilitary Ossewabrandwag was transferred by the spy, Robey Leibbrandt, who later fell out with and was betrayed by its leadership (Fedorowich, 2005), one of many pro-Nazi, anti-British paramilitary orders styled on the Nazi SA (Sturm Abtleilung or Brown Shirts) that sometimes battled with South African and British soldiers, carried out sabotage, or engaged in espionage (Campbell, 1943; Fokkens, 2012; Furlong, 1988, 2005; Gibbs, 1950; Hodes, 2014; Marx, 1994; Scher, 1986; The Security Service, 1943; Van Rensburg, 1956; Wikipedia Contributors, 2015). They were even more nationalist, anti-democratic, anti-Semitic, and saw South Africa as a national socialist dictatorship based on Dutch Nordic identity and a Protestant Theocratic State espoused by Dr Du Plessis (Gibbs, 1950). Goebbels, always an opportunistic propagandist, had instituted the highly listened to and well-received Afrikaner language of Zeesen radio transmissions 1931-1944 (Chetty, 2012; Church, 1939; Gibbs, 1950; Marx, 1992; Mhlambi, 2015; Monama, 2014; Saerchinger, 1938). In 1941, Goebbels reassured the South Africans that Germany would respect their independence (Sowden, 1944). This statement was in direct contradiction to the intelligence that led to Namibian intervention in April 1939 (1944).

Malan couched his arguments for not going to war in support of Britain using terms identical to those of Hitler, that an attack on Germany was a godless Bolshevik plot driven by Jewish world financial interests and that, in addition, such a move would favour British capitalism in South Africa (Gibbs, 1950; Thomson, 2008). The only protection from Jewish predators of South African gold would be a nationalist religious constitution. Like in Germany, the Jews were to be the scapegoats of the dictatorship. The nationalists remained publicly committed anti-communists in the 1930s (Harrison, 1982; Thomson, 2008). They also were adamant that they were uniquely African (Thomson, 2008). Malan's political platform for the 1948 elections was one, foremost, of cultural chauvinism. It had three equal planks: apartheid, religious conservatism and anti-communism; history has tended to ignore all but the first, but the other two were equally important at the time (Thomson, 2008). The NP surprised everyone by a leap to power in the election of May 1948. The start of nationalist power saw the concentration of wealth into Afrikaner hands. Black South Africans were relegated to an increasingly subservient and disempowered role. We must recognise here another possible turning point: South Africa's recognition of the failure of Nazi ideology and its repulsion towards the outcome of the belief in Volkish superiority that led to genocide in Nazi-held territory. This series of events horrified previous German supporters 
(Giliomee, 2016). The English settlers and pro-Smuts Afrikaners could have crossed tightly defined Eurocentric Volkish groupings in South Africa to become more united. Many South Africans were divided as to the intentions of Germany towards South Africa. Those with a sense of history saw the same threat from Germany as they did from GSWA: The intention to colonise, displace Afrikaners, and take Afrikaner wealth for the benefit of a European power. Others so hated the English that a German overseer was seen as more negotiable or otherwise somehow preferable. As mentioned, Goebbels' reassurances seemed believable at the time. Smuts prevailed because he united the more centrist Afrikaners with English and was just more anti-German than many of them, probably because his experiences in World War I.

After the end of World War II, there was a loss of support for Nazi extremist views by many people in the centre of the Dutch Church. This was as a result of the disclosure of Nazi genocide and the details arising from the Nuremberg Trials. This reaction could have been deployed to unite the majority of white South Africans against extremism, and could have enabled the more liberal parts of the right-wing of South African politics to modify the pronouncements of the harshest proponents of Nazi-like policies. However, this turning point opportunity was lost. The birth of the United Nations (UN) and the widespread appeal of newly emerging concepts of Universal Human Rights led to a fear of rising democratic rights and aspirations amongst the racial majority. Racial fear prevented any softening of attitudes and may have even caused a hardening of apartheid sentiments. A similar expression was found with increasing calls for justice in post-World War II Jim Crow South. This too was met with a hardening within the deep South of the United States for enforcement of Jim Crow laws, and stronger opposition to intervention from more liberal elements in the rest of the country.

\section{The British colonialist attitude after the start of decolonialism}

The British might have been uncomfortable with nationalist policies, but most of that discomfort was based on concern over whether the nationalists would impact profits. British missionaries and humanitarians played an important role and were a reasonable resort for entreaties from black leaders in the form of petitions starting as early as the 1870 s. From the establishment of a tiny intelligentsia in the black community through to its disappointment with continued British racism, even after World War I, through to the petition after the Atlantic Charter, there was very little evidence of radicalism. Their pleas for help still fell on deaf ears (Limb, 2010). 


\section{Indigenous people respond to nationalist provocation}

Slowly stripped of all representation, voice, power, and especially wealth, the black community, by far the greater part of the population, was collectively impoverished. This emasculation and impoverishment would obviously lead to a black response (Gell, 1953). The African response was much more cultured and nuanced than would be expected from a people suffering this level of abuse in a post-World War II environment. The Atlantic Charter brought a new optimism in African independence movements. These movements in South Africa petitioned in 1940 that they be allowed to have representation. They were buoyed by Article iii with its reference to anti-colonialism and self-determination and access to open free markets. This was paid lip-service during the Cold War period when support of European colonial colleagues and pro-American regimes prevented any support for independence. Americans feared that even civil rights movements could be hijacked by communism. The formation of the UN and the Declaration of Universal Human Rights, as well as UN-backed rejection of racial stereotyping (UNESCO, 1952), were all major empowerments to black aspirations.

It is now very clear that the desire for freedom amongst disenfranchised black South Africans was essentially an internal one that grew from political and economic oppression; it was not a product of outside agitation. The excesses of the colonialists and nationalists ensured that full democracy would become an Africanist aspiration. There was a resistance to any appearance of an armed struggle at this time, partly as a result of the fear within the African movements of not wanting to be seen as furthering Russian objectives in a strategically important part of the world. It was with great prescience that Oliver Tambo tried hard to prevent the black struggle being seen as taking sides in the Cold War. The nationalists tried equally hard to do the opposite and frame black aspirations as communist threats. American and Western indifference to African pleas eventually forced the ANC to seek support from Russia, the only place where it was being offered. This had consequences. The move to armed struggles was slow and reluctant, and was forged in an alliance with leftist revolutionary elements (Ellis, 2011). The struggle started slowly and had only a few hundred trained fighters even two years after its start (Shubin, 2008). Even so, the ANC was under direct CIA engagement by the mid-1950s and reportedly the CIA was the source of information leading to the Rivonia arrests (Thomson, 2008:43).

\section{Multicultural support for more equal treatment moves to the left}

Later African aspirations, and those of more fair-minded Europeans in South Africa, culminated in the Freedom Charter. The formulation of the Charter was suppressed 
by the repressive regime because if was as a large, mixed-race, multi-ethnic and multi-class group that came together to write it. The Freedom Charter was an exemplar of multicultural reconciliation and reasonable demands (Editors, 1955). Its weakness was in its appeal for state ownership and equal distribution of national resources. These were not unreasonable demands considering wide-scale nationalisation in post-war Europe, but they were antithetical to the Afrikaners in power. It looked like communism, and this did not sit well with Anglo-American capitalists either. The response to the writing of the Freedom Charter was typically repressive and led to the arrest of its leaders. It was even claimed that the Charter was evidence of a a criminal conspiracy to bring about a communist overthrow. The trial went on forever, but was ultimately unsuccessful. It is unclear if even the nationalists actually believed their own charges. I think they did, but there needs to be an analysis of internal communication to say definitively one way or another. It was certainly enough to scare off a McCarthyism-ridden America from supporting the Freedom Charter, and that might have been part of the motivation for the charge in the first place. The other was to hold the framers of the Charter in custody long enough to let things settle down (Sparks, 1990:240-242).

The African response to provocation was bipolar. One side sought to engage colonial masters in terms of civil rights or human rights and to operate through colonial legal structures, that is, to appeal (somewhat naively) to the colonial master's better natures often in terms of newly adopted Christian values. They saw colonialists as progressive and evolving. The other mode of action sought to gain independence and self-determination as promised in the Atlantic Charter. The internal political dynamics behind these points of view were mixed and complex. The more conservative approach was dominated by existing elites, often within traditional authority structures. The ANC, coming from a traditional Native Council origin, had more sympathies amongst the traditional authoritative structures, because chiefs were often scared away from communist engagement due to fears that their traditional power would be usurped. The suggestion supplied by the nationalists that Marxists would destroy the neo-traditional authority of the Native Council gave them pause (Robins, 2016).

\section{Communism amongst African indigenous groups}

American rhetoric during the Cold War was reserved for two constituencies: The political audience at home first, and in support of international capitalism second. The overarching goal of American policy towards Africa was to prevent the spread of communism anywhere. This was a favoured trope the NP knew it could manipulate. 
As the left wing of the ANC became more supported by mass movement outside of traditional authority, they often employed Marxist rhetoric and spoke of struggle and equality rather than the more conservative native's calls to rally around civil or human rights as the basis of struggle. These different approaches were often blended and never very clear (Fortescue, 1991). SACP had some influence, but traditional ANC leaders remained unsure (Nugent, 2012:302). Walter Sissulu, Brian Bunting and Ruth First visited the Soviet Union in 1950 (Shubin, 2008). The rioting that broke out in South Africa on that May Day convinced the National Party regime that it needed to suppress communism (Thomson, 2008).

Communism was systematically made illegal in South Africa with recommendations that it be treasonable and might carry a death sentence. As a result of Russian cooperation with the Smuts World War II government and allies in general, the Union of Soviet Socialist Republics (USSR) opened a consulate in South Africa in 1942, but it was closed in 1956 amid mounting hostility on the part of the nationalist apartheid regime. The Soviets were accused of engaging in subversive activities. In the 1950s, this became a hailstorm of protest with nationalist invective about interracial sex amongst godless communists, calls to close the Soviet Consulate by the Dutch Reformed Church, fears of the expropriation of South African wealth, claims that communism was despotic, and most ironic of all, that communism incited interracial hostility (Bunting, 1964:Chapter 10). This fervour was again located in distant global tendencies and politics, as it was situated in the milieu at the height of the Cold War.

Wherever there were struggles of independence in Africa, the Soviets avowed moral support. This was invoked by nationalists as proof of probable outside interference, casting Soviet support in the terms of anti-capitalist, atheist, foreign domination, and a threat to American world order (Citino, 1991). This threat was a potent claim by the nationalists for them to be either left alone to deal with it, or to be used to frighten American interests to invoke intervention. The nationalists cleverly manipulated American opinion throughout the Cold War and were keen to join in multinational policing actions in proxy wars such as the Berlin Airlift, the Korean conflict, and by offering to join the North Atlantic Treaty Organization (NATO) (Borstelmann, 1993). In 1960, the USSR declared universal support for decolonial actions as a policy it had always supported but had not formalised (Schmidt, 2013).

Nationalism, be it of Afrikaner National Party origin, or from the African National Congress, or in the form of various Pan African nationalisms, comes from a rise of intellectual imagining promoted by elites. It is hard to situate these struggles within a class structure, as a worker-based or mass-peasant movement because they were both from below and from traditional authority groups working together (and at times against each other) to promote a decolonial agenda. The South African 
indigenous left was constantly in flux because it was supported by platforms of migrant workers and sedentary farmers, and was never sufficiently fixed to enable a coherent mobilisation. This was a side effect of the homeland Bantustan policy that may have been intended; it certainly benefitted nationalist resistance to progressive humanitarian change. Population dislocation of black South Africans effectively stopped an anti-capitalistic mass movement from being formed into a popular and united front of action. So, besides imposing near serfdom, the land acts and pass laws imposed on black workers ensured their inability to organise properly and worked to keep wages at poverty levels (Sparks, 1990). The tiny African intellectual elite was kept both small and at an arm's length from sources of power within the governmental framework in a typical effort of imperial racism (ibid.). This colonial stratagem succeeded in artificially lowered wages, but this had the effect of suppressing local demand and ultimately hindered the development of the nation, just as Booker $\mathrm{T}$ Washington had noted, "One man cannot hold another man down in the ditch without remaining down in the ditch with him" (Washington, 2014). The fear of a subjugated majority predisposed the nationalists towards instituting a colour bar and then full apartheid. The less fair the system became, the more repressive it had to become, thereby sowing the seeds of its own inevitable destruction.

By the start of the armed struggle, a number of African freedom struggles were complete or nearing inevitable completion, notably in the French possession of Algeria and British Ghana. The "winds of change" speech by British Prime Minister Harrold MacMillan and pronouncements by American President John Kennedy demonstrated to the nationalists that their days were numbered. To delay the inevitable removal of non-democratic white dominance, the NP and its allies answered with secession from the Commonwealth, a ratchetting-up of terror, and turning a deaf ear to ever more clamorous entreaties by both the free world and Eastern Bloc. Apartheid South Africa was becoming a pariah state. Maintained by revenues from gold and its proxy wars in Asia, the apartheid regime was able to hang on for another 30 years.

\section{International response to perceived communist threat}

America was stuck in a logic of capitalism and did not see that its short-term selfinterest in supporting repressive regimes in southern Africa would promote the cause of Marxism, which was the one thing it feared most. (The whole of this subject is fully discussed in the book, Apartheid's Reluctant Uncle [Borstelmann, 1993].) Despite the apartheid regime's penchant for provoking a black response, the regime was seen as an effective bulwark against Soviet interest in strategically important South Africa (Thomson, 2008:7,23). The repression of all political 
redress and opposition, the rejection of outside intervention, and the continuation of gross racial inequities ensured that after 1950 the black response would be forced to turn towards revolutionary action. America recognised that ignoring legitimate political grievances would push the apartheid regime to ratchet up its security apparatus until it provoked racial violence (Thomson, 2008:23). Repressiveness of apartheid grew in concert with the response of black and liberal activists (Thomson, 2008). The NP was able to use the bogey of communism to pass The Suppression of Communism Act to give itself draconian powers to suppress dissent. It sought approval for these acts by scaring opposition from America with invoking Soviet support (Borstelmann, 1993; Thomson, 2008). Even American critics of the nationalists acknowledged their vocal and fierce anti-communist credentials (Visser, 2007).

Any American second thoughts about support for the NP were silenced by the invasion of Korea, as attention to global politics supplanted concerns over civil rights. South Africa capitalised on this turn of events by volunteering units of the South African Defence Force for action in Korea. The racist attitude of America can be seen by its constant support for Eastern Europeans and indifference to African suffering (Thomson, 2008:30). All thoughts of support for ANC-led African selfdetermination faltered on the need to support colonial powers in Europe, even though America considered that this would push the liberation struggle into Soviet hands. The USSR was very much the follower rather than the instigator of Cold War interest in Southern Africa (Thomson, 2008). The constitutional crisis of 1951 was resolved by another open Hitler admirer, J.G. Strijdom (Noer, 1985:41). He used the unconstitutional means of house and court packing. He was particularly annoyed by liberal protest that crossed racial boundaries (ibid.:40). Despite this, the American administration under President Dwight Eisenhower continued to be persuaded by NP goading and internal McCarthyism to see Soviet expansion behind every liberation movement (Borstelmann, 1993). The strategic position of South Africa, the explosion of Soviet atomic and thermonuclear weapons, and concern over South African uranium further intensified these fears (ibid.). The truth was that the USSR was playing catch-up at this time and was only responding to American intervention (Thomson, 2008:44). America knew of the eightyyear history of Russian involvement in South Africa from the time that Russian volunteers were fighting for the Boers in the Anglo-Boer War and feared ongoing involvement. However, complete bilateral ties between the ANC and the USSR were not developed until 1960 (Shubin, 2008:239). America took notice of all visits to the USSR by South African communists and of all connections between African nationalist and Pan African movements. Soviet rhetoric supportive of liberation resonated with American neuroses (Borstelmann, 1993). This saw the Roosevelt position of being receptive to, but not supportive of, pleas for civil and human rights 
in South Africa weakened by the blatantly racist Truman (1993:Chapter 3) and rejected by Eisenhower. This would reverse again under Kennedy (Noer, 1985), but ever-hardening positions from President Lyndon Johnson through President Richard Nixon culminated in the outright rejection of any humanitarian pleas by the hawkish administration of President Ronald Reagan (Thomson, 2008). The tropes marshalled by supporters of the apartheid government had taken hold of the American government. This is illustrated by writings in the State Department's journal, Problems of Communism, that stated that due to contacts with Moscow the ANC had moved from being, "dedicated to the pursuit of civil and political rights, to a vanguard movement with strong Marxist-Leninist elements with its political goals being, ... an ally of the USSR in its geopolitical aims" (Thomson, 2008:5-6). Even as the Americans adopted harsher rhetoric against the apartheid government, it invariably increased official cooperation with it, or at least prevented sanctions (Borstelmann, 1993). They thereby lost friends on both sides of the struggle and empowered leftist leaning (Noer, 1985). The American response vacillated between outright support by civil rights leaders, to being outraged, from wishing to have democracy to the claim of Representative Joe Waggoner of Louisiana that, "... the natives are not capable of producing any semblance of what we call civilization" (Noer, 1985:225). (See Chapter 6 of his book, No Easy Solution, for more detail.)

\section{Later Dutch-Afrikaner attitudes}

Like the early American colonialists, the Dutch escaped British colonial imperial power and with The Great Trek, they threw off the suffocating British. They effectively decolonised themselves and then continued to become both a postcolonial people and an internal settler-colonial community (Mignolo, 2009). They escaped the colonial power imposed upon them only to impose it on others. Their escape was not driven by a capitalist drive, because they left the richer resource base for a much poorer one in the Karoo. Lastly, they were not driven by egalitarian drives even though they had the dignity of shared poverty. The Voortrekkers did not have a strong class structure. Their authority system was based around their church and community. They invested the land with agency and the power to transform and define themselves as a linguistic-ethnic-religious people, effectively a nation-state without the trappings of nationhood. They lived an illusion of freedom located within the logic of colonialism (2009).

The British left them alone initially but soon made incursions into the Natal region because it had good ports. The discovery of vast wealth in the South African interior ensured that their Republics would be destroyed by colonialisation in classic capitalistic resource appropriation. This culminated in their national identity being 
destroyed by the British in the Anglo-Boer wars, although recently, this attitude has been subject to some revision (Grundlingh, 2010). The attack on the Dutch ended with Milner's attempt to destroy the Afrikaner. This only strengthened them further, leaving them with the resentment of a colonised people. Upon their freedom in the post-World War I period, they behaved like newly decolonised people. They took on the values of their oppressors, harked back to a mythological beatific past, and sought every kind of privilege for themselves. In adopting their colonial master's values, they saw themselves as an elite, becoming more patronising, more racist, and more keen to maintain their own internal colonialist relationship (Mignolo, 2009; Therborn, 2020:Chapter 4). They were at one and the same time postcolonials and settler-colonialists. This situation is unique to South Africa, but the British-Americans came closer to this position than any other settler-colonialist society (Mignolo, 2009:82-94). Although the Afrikaners saw themselves as an indigenous people, in effect they were postcolonial internal colonisers. They had adopted some of the same attitudes as the British. The Afrikaner position was very different from settler-colonialists with a much shorter history like those in Zimbabwe or in Kenya.

\section{Discussion of turning points}

What turning points can we identify in the context of global sociopolitical movements? The first is that, if it was not for mercantile meddling, a more integrated and harmonious society might have developed in South Africa from the beginning. Some of the Dutch peasants who slipped away from the tiny settlement around Table Mountain to be beyond the control of the VOC were able to coexist with indigenous groups without undue hostility. Their liberty posed a threat to the VOC, however, and the company soon made efforts to return these distant settlers to the confines of the defined VOC settlement.

We can recognise another lost turning point as the failure of Dutch settlers and African indigenous peasants to seek interracial unity in the face of rapacious British imperial power. The British succeeded in colonising South Africa because the fight against them was piecemeal and uncoordinated. The Dutch felt no unity with the native African groups due to their history. Some even felt more kinship with the English than the African although this would not last.

Another turning point was lost when Dutch settlers could have united with indigenous African populations to thwart British expansion into the Boer Republics. The Dutch narrative of racial struggle and battle and growing support of racial segregation prevented them working to create a unified front against the British. 
The end of the Boer War was another lost turning point. Indigenous Africans and Afrikaners could have forged an alliance at this time for better treatment, but the racialised antipathy between the two groups was strong despite their sharing of many common struggles. Instead of seeking common community with fellow South African indigenous people, Afrikaners strongly advocated for colour separation and separate identity. This was an inevitable outcome of the creation of a group identity based on shared language, ethnicity, and culture that emphasised the ethnic separateness of the Boers and their racial struggle in the face of British colonial action. Race was now paramount.

The next opportunity would have been to unite against the British in a common cause. Racism stopped this from the start. The next time would have been in the 1930s if indigenous African and Afrikaner workers had joined forces in light of the Depression and turned away from incipient nationalism in a united class-struggle against entrenched foreign exploitation.

After the Second World War, the Afrikaners could have led the way on the African continent for recognition of human rights. The magnanimous attitude of Jan Smuts and his efforts at the UN could have been applied at home, but the Afrikaners' desire for privilege and divisions within their own ranks led to the racist solution of apartheid winning out.

We can also see how the wording of the Freedom Charter affected its reception. The document, with its apparent espousal of godless communism, could have been formulated in a way that made it less prone to attack. With the growth of communism, a more enlightened group of traditional power authorities could have joined the liberal whites and used the communist bogeymen themselves to cajole American self-interest to be on their side rather than that of the NP. Failing that, an argument could be made that to have started armed struggle as soon as apartheid was installed would have taken advantage of public opinion outside of South Africa that was supportive of self-determination and would have occurred before the state apparatus of repression became entrenched and powerful.

In the end, most turning points were lost because the issue or race was mobilised in service of short-termed political expediencies or to ensure the continuation of long-term economic inequalities.

\section{Conclusion}

This slow rejection of Africanist causes led to ever-hardening of the NP policies. Malan's strict successor, Strijdom, was followed by an even more repressive Verwoerd. Attempts to export American-style civil rights actions, for example, the Johannesburg bus boycott, met harsh resistance. Boycotts and other acts 
of civil disobedience were never as strong as that in Montgomery because the South African black community was divided into factions, because the pass laws ensured a lack of cohesion, and because the regime was less scrutinised by foreign powers and hence less inhibited in its use of violence to suppress peaceful protests (Borstelmann, 1993). This harsh attitude culminated in the Sharpeville massacre. The ANC was soon to declare its own armed struggle. However, this coincided with a number of other global events. Kennedy was assassinated, the Vietnam War had started, Cuba was in crisis, the Cold War now consisted of proxy actions fought in third countries, and the Cold War threatened to become a hot war or even a nuclear war. The desire to avoid national destruction in a nuclear conflict led to the Cold War becoming a series of regional, hot proxy wars in Africa. The populations of America and Russia - the real protagonists in these wars - were safe and this was itself an unspoken manifestation of racism. Although these proxy wars were well funded at their start, they continued long after global interest in them started to wane. The apartheid regime took advantage of this lack of focus towards South Africa in global politics, to set about installing a rigid apparatus of repression in a regime that would last another $30+$ years (Thomson, 2008). This was also a time when local politics become increasingly internal as South Africa was isolated by the Western powers. This policy of isolation by the West was for local and internal aims. Western powers (by appearing to be prodemocratic, egalitarian and anti-apartheid) were eager to mollify and distract the world from their own domestic problems such as the American civil rights movement. Within South Africa, isolation lead to lessening of global geopolitical influence and an increase in locally generated contours of fear, with action and reaction. The draconian nature of late-stage apartheid and the cost of maintaining it led to its downfall not by outside pressure or outside ideals being applied. Its end was presaged when the Dutch Reformed Church declared apartheid a "heresy" in 1988 and its Stellenbosch intellectual base deserted the cause. This settled the fate of the NP, despite the apparent military power of the state. When the cost of maintaining that military power exceeded the ability of the state to fund it, it ushered in the end of apartheid. The demise of apartheid was, in the end, from a local cause of economic necessity.

The Rainbow Nation that followed the fall of apartheid was one example where a racial turning point was bravely embraced by all sides and the expected rancour and retribution was avoided. That process is ongoing and needs to be carefully tended. However, in the greater history of South Africa, numerous other potential turning points where racism may have given way to interracial solidarity were squandered by the influence of commercial, colonial and global political pressures to benefit short-term interests and protect profits. This resulted in long-term impoverishment of South Africa with a terrible cost to its humanity. 


\section{Acknowledgements}

A comment by one of the reviewers helped me crystalise my viewpoint. This reviewer said I had privileged the views propounded by communist influences in South Africa by using Nazism as an insult. I never meant to do this. From an historic viewpoint, Nazism was to its contemporaries a political new world order; that was until it became a travesty of itself. Others have expressed to me that, by thinking of South Africa as being influenced by Nazism, I was playing into the hands of communist rhetoricians. Yet others thought I discounted local egalitarian anti-apartheid positions as being driven by foreign movements. I think this sums up this chapter; it will never make anyone happy, but I have tried to look beyond local polities and their own conceptions of statehood for South Africa, to see the theatre as it played out on a world stage. I thank many people for long and often difficult discussions around this chapter. This is the essence of a venue like STIAS. In the end, these are only my own views. I would like to thank everyone who has taken time to talk to me, send me material, and read through my many earlier drafts. 


\section{References}

Amponsah, D.K. 2013. Christian slavery, colonialism, and violence: The life and writings of an African ex-slave, 1717-1747. Journal of Africana Religions, 1(4). https:// doi.org/10.5325/jafrireli.1.4.0431

Bentwich, N. 1942. Jewish life in British South Africa. Jewish Social Studies, 4(1). https:// www.jstor.org/stable/4615189

Bernasconi, R. \& Lott, T.L. (eds.). 2000. The Idea of Race. Indianapolis, IN: Hackett Publishing Company Inc.

Bloomberg, C. \& Dubow, S. 1990. Christian Nationalism and the Rise of the Afrikaner Broederbond in South Africa, 1918-48. London: Macmillan Press. https://doi. org/10.1007/978-1-349-10694-3

Borstelmann, T. 1993. Apartheid's Reluctant Uncle: The United States and Southern Africa in the Early Cold War. New York: Oxford University Press.

Bunting, B. 1964. The Rise of the South African Reich. Harmondsworth: Penguin Books.

Campbell, A. 1943. Smuts and Swastika. London: Victor Gollancz.

Chamberlain, H.S. 1911. The Foundations of the Nineteenth Century. London: John Lane.

Chetty, S. 2012. Imagining national unity: South African propaganda efforts during the Second World War. Kronos, 38. https:// www.jstor.org/stable/41940663

Childers, T. 1984. Who, indeed, did vote for Hitler? Central European History, 17(1). https://doi.org/10.1017/ S000893890000114X

Church, G.F. 1939. Short waves and propaganda. The Public Opinion Quarterly, 3(2). https://doi.org/10.1086/265285

Citino, R.M. 1991. Germany and the Union of South Africa in the Nazi Period. New York: Greenwood.

Cox, O.C. 2000. Race relations. In: L. Back \& J. Solomos (eds.). Theories of Race and Racism: A Reader. London: Routledge.
De Gobineau, A. 2000. The inequality of human races. In: R. Bernasconi \& T.L. Lott (eds.). The Idea of Race. Indianapolis, IN: Hackett Publishing Company Inc.

Dubow, S. 1992. Afrikaner nationalism, apartheid and the conceptualization of 'race'. The Journal of African History, 33(2). https://doi.org/10.1017/ S0021853700032217

Dubow, S. 1995. Scientific Racism in Modern South Africa. Cambridge: Cambridge University Press.

Dubow, S. 2010. South Africa: Paradoxes in the place of race. In: A. Bashford \& P. Levine (eds.). The Oxford Handbook of the History of Eugenics. New York: Oxford University Press.

Dubow, S. 2015. Racial irredentism, ethnogenesis, and white supremacy in high-apartheid South Africa. Kronos, 41(1). https://www.jstor.org/stable/43859441

Duffy, J.L. 2006. The Politics of Ethnic Nationalism: Afrikaner Unity, the National Party, and the Radical Right in Stellenbosch, 1934-1948. New York: Routledge.

Du Plessis, I.D. 1972. The Cape Malays: History, Religion, Traditions, Folk Tales, the Malay Quarter. Cape Town: A.A. Balkema.

Durham, M. \& Power, M. 2010. Introduction. In: M. Durham \& M. Power (eds.). New Perspectives on the Transnational Right. New York: Palgrave Macmillan US. https://doi.org/10.1057/9780230115521

Du Toit, A. 1983. No chosen people: The myth of the Calvinist origins of Afrikaner nationalism and racial ideology. The American Historical Review, 88(4). https://doi.org/10.2307/1874025

Editors. 1955. The Kliptown Conference. Africa Today, 2(4). https://www.jstor.org/ stable/4183735

Ellis, S. 2011. The genesis of the ANC's armed struggle in South Africa 1948-1961. Journal of Southern African Studies, 37(4). https:// doi.org/10.1080/03057070.2011.592659 
Fanon, F. 1963. The Wretched of the Earth. New York: Grove Press.

Fanon, F. 2008. Black Skin, White Masks. New York: Grove Press.

Fedorowich, K. 2005. German espionage and British counter-intelligence in South Africa and Mozambique, 1939-1944. The Historical Journal, 48(1). https://doi. org/10.1017/S0018246X04004273

Fokkens, A.M. 2012. Afrikaner unrest within South Africa during the Second World War and the measures taken to suppress it. Journal for Contemporary History: Military History 1912-2012, 37(2). https://hdl. handle.net/10520/EJC133205

Fortescue, D. 1991. The Communist Party of South Africa and the African working class in the 1940s. The International Journal of African Historical Studies, 24(3). https:// doi.org/10.2307/219090

Fritz, S.G. 1987. The NSDAP as Volkspartei? A look at the social basis of the Nazi voter. The History Teacher, 20(3). https://doi. org/10.2307/493126

Furlong, P.J. 1988. Pro-Nazi subversion in South Africa, 1939-1941. Ufahamu: A Journal of African Studies, 16(1). https:// escholarship.org/uc/item/7g4406gv

Furlong, P.J. 2003. Apartheid, Afrikaner Nationalism and the Radical Right: Historical revisionism in Hermann Giliomee's The Afrikaners. South African Historical Journal, 49(1). https://doi. org/10.1080/02582470308671455

Furlong, P.J. 2005. Allies at war? Britain and the 'Southern African Front' in the Second World War. South African Historical Journal, 54(1). https://doi. org/10.1080/02582470509464896

Furlong, P.J. 2010. The National Party of South Africa: A transnational perspective. In: M. Durham \& M. Power (eds.). New Perspectives on the Transnational Right. New York: Palgrave Macmillan US. https://doi.org/10.1057/97802 30115521_4
Gell, C.W.M. 1953. Hard choices in South Africa. Foreign Affairs, 31(2). https://doi. org/10.2307/20030961

Gibbs, H. 1950. Twilight in South Africa. New York: Philosophical Library.

Gilbert, S. 2010. Jews and the racial state: Legacies of the Holocaust in Apartheid South Africa, 1945-60. Jewish Social Studies, 16(3). https://doi.org/10.2979/ jewisocistud.16.3.32

Giliomee, H. 2000. Critical Afrikaner intellectuals and Apartheid, 1943-1958. South African Journal of Philosophy, 19(4). https://doi.org/10.1080/02580136.2000. 11644282

Giliomee, H. 2003a. The making of the Apartheid Plan, 1929-1948*. Journal of Southern African Studies, 29(2). https:// doi.org/10.1080/03057070306211

Giliomee, H. 2003b. 'The weakness of some': The Dutch Reformed Church and white supremacy. Scriptura: International Journal of Bible, Religion and Theology in Southern Africa, 83(1). https://hdl.handle. net/10520/EJC100636

Giliomee, H. 2008. Ethnic business and economic empowerment: The Afrikaner case, 1915-1970. South African Journal of Economics, 76(4). https://doi.org/10.1111/ j.1813-6982.2008.00215.x

Giliomee, H. 2012. Bantu education: Destructive intervention or part reform? New Contree, 65. http://hdl.handle. net/10394/8262

Giliomee, H. 2016. Hermann Giliomee: Historian: An Autobiography. Cape Town: Tafelberg. https://doi.org/10.2307/j. ctt1zkjzr0

Giliomee, H. \& Mbenga, B. 2007. New History of South Africa. Cape Town: Tafelberg.

Goldin, I. 1987. Making Race: The Politics and Economics of Coloured Identity in South Africa. Cape Town: Maskew Miller Longman.

Grundlingh, A. 1990. Politics, principles and problems of a profession: Afrikaner historians and their discipline, 
c.1920-c.1965. Paper presented at the Wits History Workshop: Structure and Experience in the Making of Apartheid. Johannesburg, February 6-10.

Grundlingh, A. 2010. Remembering conflict. In: M. Diawara, B. Lategan \& J. Rusen (eds.). Historical Memory in Africa: Dealing with the Past, Reaching for the Future in an Intercultural Context. New York: Berghahn Books.

Harrison, D. 1982. The White Tribe of Africa: South Africa in Perspective. Berkeley, CA: University of California Press.

Hodes, R. 2014. "Free Fight on the Grand Parade": Resistance to the Greyshirts in 1930s South Africa. The International Journal of African Historical Studies, 47(2). https://www.jstor.org/stable/24393404

Hofmeyr, J.H. 1939. Germany's colonial claims: A South African view. Foreign Affairs, 17(4). https://doi.org/10.2307/20028964

Jablonski, N.G. 2012. Living Color: The Biological and Social Meaning of Skin Color. Berkeley, CA: University of California Press.

Klausen, S. 2002. The uncertain future of white supremacy and the politics of fertility in South Africa, 1930-1939. Paper presented at the University of Natal African Studies Seminar. Durban.

Krikler, J. 2005. White Rising: The 1922 Insurrection and Racial Killing in South Africa. Manchester: Manchester University Press.

Lachance, J.; Vernot, B.; Elbers, C.C.; Ferwerda, B.; Froment, A.; Bodo, J-M.; Lema, G.; Fu, W.; Nyambo, T.B.; Rebbeck, T.R.; Zhang, K.; Akey, J.M. \& Tishkoff, S.A. 2012. Evolutionary history and adaptation from high-coverage wholegenome sequences of diverse African hunter-gatherers. Cell, 150(3). https://doi. org/10.1016/j.cell.2012.07.009

Larson, E.J. 1995. Sex, Race, and Science: Eugenics in the Deep South. Baltimore, MD: Johns Hopkins University Press.
Lerumo, A. 1980. Fifty Fighting Years: The Communist Party of South Africa, 1921-1971. London: Inkululeko.

Limb, P. 2010. The ANC's Early Years: Nation, Class and Place in South Africa Before 1940. Pretoria: Unisa Press.

Marx, C. 1992. 'Dear Listeners in South Africa': German propaganda broadcasts to South Africa, 1940-1941. South African Historical Journal, 27(1). https://doi. org/10.1080/02582479208671742

Marx, C. 1994. The Ossewabrandwag as a mass movement, 1939-1941. Journal of Southern African Studies, 20(2). https:// doi.org/10.1080/03057079408708396

Mhlambi, T.N. 2015. Early Radio Broadcasting in South Africa: Culture, Modernity and Technology. PhD Thesis. Cape Town: University of Cape Town.

Mignolo, W.D. 2009. The Idea of Latin America. New York: John Wiley \& Sons.

Monama, F.L. 2014. Wartime propaganda in the Union of South Africa, 1939-1945. PhD Thesis. Stellenbosch: Stellenbosch University.

Noer, T.J. 1985. Cold War and Black Liberation: The United States and White Rule in Africa, 1948-1968. Columbia, MO: University of Missouri Press.

Nugent, P. 2012. Africa Since Independence: A Comparative History. New York: Palgrave Macmillan. https://doi.org/10.1007/9780-230-39356-1

Ritner, S.R. 1967. The Dutch Reformed Church and Apartheid. Journal of Contemporary History, 2(4). https://doi. org/10.1177/002200946700200404

Robins, S.L. 2016. Letters of Stone: From Nazi Germany to South Africa. Cape Town: Penguin Books.

Ross, R. 2013. The Borders of Race in Colonial South Africa: The Kat River Settlement, 1829-1856. Cambridge: Cambridge University Press. https://doi.org/10.1017/ CBO9781107337039 
Rowe, A.C. \& Tuck, E. 2016. Settler colonialism and cultural studies: Ongoing settlement, cultural production, and resistance. Cultural Studies $\leftrightarrow$ Critical Methodologies. https://doi. org/10.1177/1532708616653693

Saerchinger, C. 1938. Radio as a political instrument. Foreign Affairs, 16(2). https:// doi.org/10.2307/20028845

Scher, D.M. 1986. Louis T. Weichardt and the South African greyshirt movement. Kleio, 18(1). https://doi. org/10.1080/00232088685310051

Schmidt, E. 2013. Foreign Intervention in Africa: From the Cold War to the War on Terror. Cambridge: Cambridge University Press. https://doi.org/10.1017/ CBO9781139021371

Shain, M. 2017. Paradoxical ambiguity D.F. Malan and the "Jewish Question". Transactions of the Royal Society of South Africa, 72(1). https://doi.org/10.1080/003 5919X.2016.1258016

Shubin, V.G. 2008. The Hot "Cold War": The USSR in Southern Africa. Scottsville: University of KwaZulu-Natal Press.

Sowden, L. 1944. The South African Union. London: R. Hale Ltd.

Sparks, A.H. 1990. The Mind of South Africa. London: Heinemann.

The Security Service. 1943. TROMPKE Organisation for German Espionage in South Africa. The National Archives of the UK. KV 2/763.

The Security Service. 2012. Oswald PIROW: South African. The National Archives of the UK. KV 2/908.

Theal, G.M. 1922. History of Africa South of the Zambesi from the Settlement of the Portuguese at Sofala in September 1505 to the Conquest of the Cape Colony by the British in September 1795. London: G. Allen \& Unwin Ltd.
Therborn, G. 2020. From settler to postcolonial: The turn of the South African nation-state. In: N.G. Jablonski (ed.). Persistence of Race. Stellenbosch: African Sun Media.

Thomson, A. 2008. U.S. Foreign Policy Towards Apartheid South Africa, 1948-1994: Conflict of Interests. New York: Palgrave Macmillan. https://doi. org/10.1057/9780230617285

UNESCO. 1952. The Race Concept: Results of an Inquiry (The Race Question in Modern Science). Paris: UNESCO.

Van Rensburg, H. 1956. Their Paths Crossed Mine: Memoirs of the Commandant-General of the Ossewa-Brandwag. Johannesburg: Central News Agency.

Van Tonder, J.M. 2013. Die pastorale rol van die Hollands-Afrikaanse kerke gedurende die Tweede Wêreldoorlog (1939-1945): 'n kerkhistoriese studie. PhD Thesis. Potchefstroom: North-West University.

Vatcher Jr., W.H. 1965. White Laager. New York: Praeger.

Vinson, R.T. 2012. The Americans Are Coming!: Dreams of African American Liberation in Segregationist South Africa. Athens, $\mathrm{OH}$ : Ohio University Press.

Visser, W. 2007. Afrikaner anti-communist history production in South African historiography. In: H.E. Stolten (ed.). History Making and Present Day Politics: The Meaning of Collective Memory in South Africa. Uppsala: Nordiska Afrikainstitutet.

Washington, B.T. 2014. Up from Slavery: An Autobiography. Cambridge: Cambridge University Press. https://doi.org/10.1017/ CBO9781316018231

Wikipedia Contributors. 2015. Greyshirts. Wikipedia, The Free Encyclopedia. https://en.wikipedia.org/wiki/South_ African_Gentile_National_Socialist_ Movement [Accessed 17 July 2016].

Wilkins, I. \& Strydom, H. 1979. The Broederbond. New York: Paddington Press. 


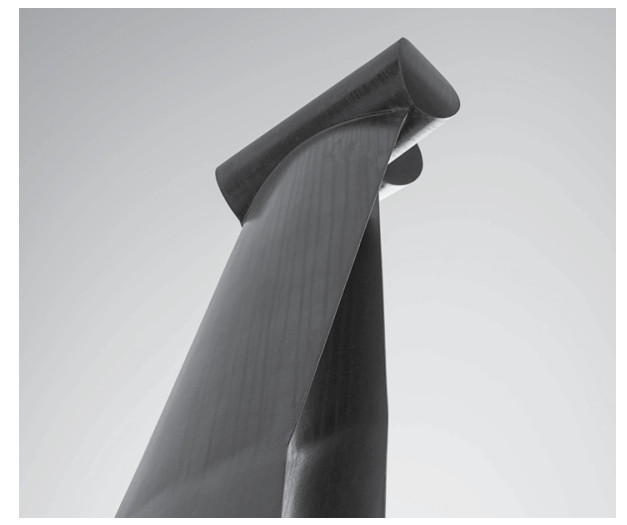

\title{
4
}

\section{FROM SETTLER TO POSTCOLONIAL \\ The turn of the South African nation-state in a comparative perspective}

\author{
Göran Therborn
}

Virtually all countries see themselves as special and unique, which they are, in a trivial sense. However, an understanding of them can often be enhanced by seeing them as part and a variant of a type. Here, I look at South Africa as a nation-state and focus on the meaning of its turnaround in 1994. I shall not go into the proper history of the South African state and its turn, although I am, of course, starting from some elementary outsider knowledge of it. Instead, I shall deploy a framework for analysing types of nation-states, once developed based on empirical historical generalisation; of the rise of the right to vote in the world (Therborn, 1992, 2011); and their sociocultural and political implications. This framework differs from the bulk of the literature, both on nationalism and on state formation, by focusing on the kind of political conflict out of which a nation-state emerged, in particular against whom the claim to statehood and political rights of the nation was asserted. 


\section{The importance of nation-states}

In these globalised times, any serious discussion of nation-states, not starting from an assumption of their decline or demise, seems to have to begin with a defending rationale. Nation-states have tremendous historical significance. Their establishment was a seal of the power of modernity. Modernity meant a novel cultural orientation, no longer uncritically accepting the wisdom and the authority of fathers and ancestors, even questioning at least handed-down interpretations of the word of God, no longer prepared to follow the practices of tradition. Instead, modern cultures looked to the future as an open horizon and as a world to be created. Modernity in this sense rose and asserted itself at different times and in different forms in different parts of the world and in different sociocultural areas, science, art, philosophy of history, economic practices, architecture, sex-gender relations, etc., including politics.

The nation-state was the key political form of modernity. While most nations invoke their past in their identity, the sovereignty of the nation-state implies a sovereignty over all past authority. The agenda of the nation-state is open to the future. The nation-state is perceived by the members of the nation as a means to create a new future for themselves. That is why there is such a demand for it. Since World War II, the number of nation-states in the world has quadrupled, and there is still unfilled demand in places like Catalunya, Kurdistan, Palestine, Scotland and elsewhere.

In terms of resources, from appropriation/redistribution of GDP to means of surveillance and of war-making and destruction, nation-states have never been stronger than today. Not only does the existence of nation-states matter, but so do their position, such as the very divisive issue of whether Britain should leave or stay in the European Union (EU) showed. It was also noteworthy that the leading campaigners in the referendum included the recent and the current Mayor of the supposedly supra-national "global city" of London, one for Brexit and the other against it.

Modern cultural orientations did not develop in any synchronised way, neither amongst sociocultural areas of human practice nor between populated territories. Modern political power was at least one of the most important victories of modernity. For analytical purposes, the nation-state has the advantage of being relatively easy to identify and to date empirically, and therefore lending itself to comparisons and effect studies. 
A nation-state is a sovereign polity claiming to represent and to be governed by a sovereign nation. This claim has always had to assert itself against other forms of political power. Struggles for a nation-state have developed along four major pathways, which may also be taken as ideal types, with some countries arriving at a nation-state along two or more routes. The sovereign nation can sometimes conceive itself as bi- or multinational, as a sovereign people consisting of two or more nationalities or national groups.

One road of struggle centred on an emerging nation against a prince, against a monarchical patrimonial state. This was the main pattern in Europe, whether by disruptive revolution, as in France and Germany, or by gradual reform, as in Britain and Scandinavia.

Another was by secession from the motherland, by wars of independence as in most of the Americas, or peaceful evolution, as by the Dominions of the British Empire. This was the way settler nations and settler-states established themselves. Settlers come from one land and occupy another. That has happened many times in history, but in the age of rising modernity the only settlers who created a nationstate were Europeans descending from conquerors of overseas lands.

Thirdly, and most frequently, nation-states emerged out of emancipation from foreign colonial rule.

Fourthly, a few of the traditional realms threatened by European and United States imperialism in the nineteenth century managed to transform themselves from above, by a section of the existing elite, into modern nation-states, and survived. Japan is the paradigmatic case.

These modes of nation-state formation, including the big hybrid cases of Russia and China, have had enduring effects on the politics, culture and society of their countries, not per se systematically and directly on their economies.

\section{South Africa as a settler-state}

The Union of South Africa was established as a settler-state. The National Convention of 1908-1909, which prepared the South Africa Act of the British Parliament, consisted exclusively of settler representatives of the four colonies, Cape, Free State, Natal and Transvaal. Modern African politics had begun by then, and native congresses "humbly" petitioned the Convention and later the British Parliament for political rights - without daring to ask for participation in the Convention - but they were all ignored (Sheridan, 1972:52-57). In the Cape Colony, non-settlers had some political rights and, in what was conceived as a 
political compromise, it could keep them. But natives had no rights in the rest of the Union, and the issues of incorporating the colonial "Protectorates" of Basutoland, Bechuanaland and Swaziland were left to the future, because their incorporation in the Union would have raised the question of African rights again. The leading Boer statesman, Jan Smuts, was explicit in his infamous 1917 speech to an imperial audience at the London Savoy hotel: "It has been our idea to make South Africa a White man's country ...” (Holland, 2012:30).

The South African Dominion became a sovereign nation-state rather soon. It was accepted as a founding member state of the League of Nations, and at the Imperial Conference in 1920, Lord Balfour declared that Britain and the Dominions had "equal status ... in regard to internal or external affairs". In the 1931 Statute of Westminster, the British Colonial Laws Validity Act of 1865 was repealed, and the Parliaments of the White Dominions got sovereign power.

All settler nations were inherently racist, all settler-states constitutively racist, because all settler rule was based on a notion of racial supremacy. South Africa was, in this respect, similar to the whole of the Americas, from Argentina to Canada, and to Australia and New Zealand, and radically different from all of Europe. Not because home-staying Europeans were necessarily less racist than European settlers, but because the issue of racial supremacy did not arise inside Europe until the Nazis invented it. But there were two significant dimensions of variation amongst the settler-states. One was their conception of race. The Anglo-Saxon and Dutch conception was binary, white and non-white. The Ibero-American was hierarchical, with a scale of gradation, from white to brown and black, deriving from rather extensive racial mixing. This racist hierarchy was not strictly exclusivist and opened important channels of individual and family social mobility in the new Latin American nation-states of the nineteenth century and later. In independent Hispanic America, Indians were normally recognised as national citizens with voting rights. There were several Mestizo Presidents and military strongmen, occasionally also Mulatto, and Mexico had a prominent, elected Indian President in the 1860 s.

Secondly, settler-states had different demographic compositions. Some had managed to kill off most of their natives, making the survivors marginal remnants in outlying peripheries, these included the United States, Canada, Argentina, Brazil, Uruguay, Chile and Australia. Others had strong native minorities, namely New Zealand and the rest of Hispanic America. Some had native majorities besides South Africa - Bolivia and Guatemala. Slavery added another demographic component. Largescale slavery was concentrated in an eastern American belt from Washington to Rio de Janeiro, and in the Caribbean islands. It was abolished in the second half of the nineteenth century, but has left enduring scars of discrimination and prejudice until this day. 
The racial issue became more central in South Africa than in the other settler-states because of a complex demography, making the essentially binary race conception difficult to manage. In 1910, whites made up $21 \%$ of South Africa's population (11\% in 1996) (Ndebele, 2016). In South Africa, settler rule had to be repressive and anti-democratic. While they have their own problems of repression and democracy, Bolivia and Guatemala never became racially polarised; this was due to large layers of Mestizos who could move in and out of power without challenging settler wealth and privileges. White settler politicians were all the time very aware, and fearful, of the settlers' minority situation, and that both political and civic rights had to be judged on the criterion of ethnic "self-preservation". The run-up to the Anglo-Boer War in 1899 centred on the issue of the franchise of the "Uitlanders" (foreigners) in Transvaal, that is, the (mainly) British immigrants who had come with the gold rush to Witwatersrand (Grobler, 2014:185ff.). So, the white settlers were themselves deeply divided, and the non-whites comprised three distinctive groupings - each of them culturally and economically very differentiated - who could never be handled as one. The South African "coloureds" were no Mestizos or Mulattos on an Iberian ladder of colour, though many were of "mixed blood". While excluded from white society, they were often not descendants of the majority black population, part of them were descendants of Malay slaves and Muslims, others of Khoi-San cum European descent, Christian and Dutch-speaking (Thomas, 2014). The Indians had originally been imported by the British as indentured labourers on the sugar plantations in Natal, later followed voluntarily by some traders (Vahed, 2014). The big group was the black Bantu.

The 1910 Union was based on a delicate reconciliation and balance between the British and Boer "races", as they were sometimes referred to at the time (Giliomee, 2014a:286), and in the preparations for the Union constitution it was underlined that "the black vote should not be permitted to upset the balance between the two white population groups ... (Scher, 2014:264). The white managing of the different non-white populations involved racial exclusion and segregation from very early on, long before post-World War II apartheid. The Native Land Act dates from 1913, and the urban Group Areas Act, excluding blacks from proper urban residence, from 1923 (Pretorius, 2014:271). In 1924, Indians were deprived of their municipal franchise in Durban, after their trade and property rights had been restricted (Vahed, 2014:578). In 1926, a Mine and Works Act reserved several jobs either for whites or for "coloureds" (Thomas, 2014:556).

\section{Racial rehabilitations}

After their national formation, many nation-states have had popular moments when the voices and the interests of the people of the nation outside its constitutive elite have broken through, have been heard and have been put on the state agenda. 
In Europe, these popular moments have mainly been working-class moments, of working-class suffrage, of "municipal socialism", and welfare states. In the settlerstates, class has been overlayered with race, sometimes overshadowed by it. As the people nearest to competition from natives, cheap foreign labour, and descendants of slaves, the settler working class has been particularly susceptible to racial demarcation. "Keep Australia White" was the first plank of the Australian Labour Party from its foundation until the early 1970s. During the white miners' mass strike in 1922, workers marched in Johannesburg under the banner, "Workers of the World! Unite and Fight for a White South Africa!" (Holland, 2012:32). In the United States, a pan-ethnic white working class constituted itself, confronting black migration to the industrial North.

Popular moments in the settler-states have, therefore, rarely had a strong workingclass character. Instead, there have been populism and racial rehabilitation. Populism, as anti-establishment "rabble-rousing" or mobilisations, usually by a charismatic leader of a structurally heterogeneous "people" against the elite, has been a very important phenomenon of twentieth-century Americas. It does not seem to have been very significant in racially rigidified South Africa. The "poor white problem", which attracted political attention and United States Carnegie research funding in the 1920s, was not a basis for populist mobilisation.

Racial rehabilitation is what in the settler-states corresponds to earlier workingclass recognition in Europe. It appeared on a broad front in all the settler-states in the last third of the twentieth century. There was international pressure from the increasingly successful anti-colonial movement and from the Soviet bloc in the Cold War. In December 1965, the United Nations (UN) adopted a Convention on the Elimination of All Forms of Racial Discrimination (in force after ratifications in January 1969). The discriminated and marginalised people of the settler-states were gathering strength generating their own intellectuals and spokespersons through niche access to study milieu, generally radicalised in the 1960s. In the United States, a courageous and militant civil rights movement, white and black, developed, finally delivering the right to vote to African Americans, about two centuries after the settler secession.

Political iconography and museums went into a mode of racial rehabilitation, soon followed by official apologies for past acts of injustice. In the 1980s-1990s, United States racial iconography started to change significantly, particularly in the federal capital. African American soldiers in America's wars were recognised, and Martin Luther King got a full memorial statue on the National Mall in 2011. An African American Museum is now, belatedly, standing on the Mall, and American Indians at last got an official recognition in a museum in 2004. 
Canada was the first of the ex-British settler-states to belatedly acknowledge the rights of the natives, who got some land rights included in the Constitution of 1982. In its Museum of Canadian Civilization in Ottawa-Gatineau, the country was also the first of the British Empire secessions to pay full official respect to the natives. Unlike later recognitions in Wellington, Canberra and Washington, the Canadian museum is not a native niche. It brings the natives into the centre of Canadian history.

Until the 1970s, "Keep Australia White" had been national policy, and the first programme plank of the Australian Labour Party. Australia has been more reluctant in recognising the natives than Canada, but in 2001, on the occasion of the Centenary of Australia's Federation, the new Australian National Museum included an architecturally ambitious annex building of "Australian Aboriginal and Torres Strait Islanders Studies". In the same year, a large commemorative ensemble was started in the Parliamentary Triangle by Lake Burley Griffin, Reconciliation Place, a claim to settler-native reconciliation, including symbolic recognitions of Aboriginal country origin, land rights, and of Aboriginal leaders.

New Zealand was unique amongst the settler-states of the British secession in having from the beginning to pay some recognition to the natives, the Maoris a relatively large, well-organised people with fighting traditions who got delimited land rights and a recognised minor place in the settler polity. However, Wellington has always been a white settler town. In 1998, an iconic Maori-centred, albeit not exclusively, National historical museum was opened, Te Papa (Our Place).

Racial rehabilitation started much earlier in the principal capitals of Iberian succession. The new states of Mexico and Peru did not see themselves as exclusively settler-states, and included pre-Columbian motifs and connections in their iconography and their master narratives. In the 1850s, the great Liberal Benito Juárez, a Zapotec Indian, became a Supreme Court Judge and, in the 1860s, President of Mexico. In the 1920s-1930s, there arose a wave of native cultural recognition, particularly in the two old imperial vice-royalties, Mexico and Peru, both centres of major pre-Columbian polities.

The implosion of apartheid in South Africa was part of this global process of existential human equalisation, which also included epochal advances of women's rights. In South Africa, the end of apartheid was more than racial rehabilitation, it meant the beginning of the construction of a new state and society.

However, before that, the country had in a way its specific form of racial rehabilitation. This was the advancement of the Afrikaner "race", with its own language - Afrikaans, no longer Dutch - on constitutional parity with English - with a national name - no longer "farmer" (Boer) - and its mobility into the urban economy (Gillomee, 2014a, b, c). This process also included a monumental 
iconography, above all the Voortrekker (Pioneers) monument, commemorating the Boers' exodus out of the British Cape Colony and the creation of a new settlement after a bloody battle victory over the Zulus, founded at the centenary in 1938 and inaugurated in 1949. Furthermore, an original modernist monumental ensemble has been dedicated to the Afrikaans language, completed in 1975, probably unique of its kind in the world.

By the 1970s, the regime had reached its limits and had to make adjustments. Industrialisation had given muscle to the black working class, and the 1970s saw a series of trade union formations and vigorous strike movements. Shortages of skilled labour opened, which capital leaders like Harry Oppenheimer explicitly laid at the door of apartheid discrimination. In 1970, the income gap between whites and Africans had reached an historical low, with the annual per capita income of the latter being only $6,8 \%$ of the former. Then it turned slowly upward, but the figure of $9,1 \%$ for 1917 was surpassed only in the second half of the 1980s (SAIRR, 2010:Chapter 79). Wages in the gold mines show the same pattern, white privilege culminating in 1970, at 20,9 times the black African wage (11,7 times in 1911), and then drastically eroding to 5,5 times in 1982 (Hirsch, 2005:11). Vital inequality also began to change in the 1970s. In 1969-1971, life expectancy at birth for a "coloured" person was seventeen years shorter than for a white person (Bureau of Census and Statistics, 1978:3.19). The gap had been relatively stable at least since the 1930s, then for 20 years after that (Bureau of Census and Statistics, 1960:B32-33). However, by 1984-1986, it was down to ten years (Central Statistical Services, 1997:3.15). White South Africa never bothered with vital statistics of the African population and, since 1991, official South African statistics produces no life expectancy data by race at all. A group of demographers have, however, made an estimate according to which black life expectancy in 1984-86 was 60 (56 for males, 63 for females) (Dorrington, Bradshaw \& Wegner, 1999), 12 years shorter than for whites, two years shorter than for "coloureds".

\section{Options and meanings of 1994}

While part of an epochal worldwide process of change of race and gender relations, and more specifically of a rehabilitation of discriminated, despised and exploited races in all the settler-states, the end of South African apartheid had a particularly profound meaning and impact. It meant the end of a state of settlers, for settlers, and by settlers. This was exceptional, but not quite unique. Something similar happened ten years later in Bolivia, after quasi-insurrectionary popular mass mobilisations against neo-liberal economic policies, negotiated into a Presidential election, electing the country's first Indian President, Evo Morales. The new government then launched a Constituent Assembly, which created a new "Pluri-national" republic, recognising the majoritarian set of Indian nations. 
The most direct reason why South Africa could not become something like post1970s United States was, of course, the demographic composition of the country. In South Africa's democracy, the former "master race" was no more than a ninth of the population, and declining.

But what was the new South Africa to be, in political culture and political economy? For the African National Congress (ANC), there appears to have been three options on the table. One was a liberal democracy and a left-wing social democracy. That was the programme of the Freedom Charter of 1955, supposedly the guide of the ANC and its allies. It was similar in content to the British Labour party programme in 1945 and to the Common Program of the Mitterand coalition in France in 1981. It was put aside without serious discussion. On Mayday 1994, Mandela was interviewed in South Africa's largest newspaper and declared: "In our economic policies ... there is not a single reference to things like nationalization, and this is not accidental. There is not a single slogan that will connect us with any Marxist ideology" (Marais, 2001:122; cf. Spitz \& Chaskalson, 2000:17). Notwithstanding, the Freedom Charter had stated: "The material wealth beneath the soil, the banks and monopoly industry shall be transformed to the ownership of the people as a whole" (Turok, 2011:33). Instead, the ANC adopted a mildly social democratic Reconstruction and Development Programme originating from the trade unions (Hirsch, 2005:Chapter 2). Radical social democracy with a socialist perspective was clearly out of tune with the times, in the period of the "Washington Consensus" on global economics, the high tide of neo-liberalism just after the implosion of the USSR and the whole Soviet bloc. South African big capital had gained ANC legitimacy by openly distancing itself from the apartheid politicians.

The second option was liberal democracy together with ordinary, developmental capitalism. In a sense, that was the default option. It was the one de facto chosen by the leadership, and the outcome many, or most, people undoubtedly think they have got. In South Africa, liberal democracy took a progressive, clearly egalitarian form. The negotiations between the regime and the opposition first laid down a set of fundamental principles with the coming new Constitution must embody, to be tested by a Constitutional Court. The first Principle was: The Constitution of South Africa shall provide for the establishment of one sovereign state, a common South African citizenship and a democratic system of government committed to achieving equality between men and women and people of all races" (Spitz \& Chaskalson, 2000).

Actually, I would argue, it has not quite turned out that way. The mortgage of the past, the century of holding down the majority population by all means available, by law, by exclusion, expulsion and spatial segregation, and by armed might has left too many scars and divides for a full-fledged liberal democracy to take root in the ashes of settler domination. 
The third option was a postcolonial democracy with a political economy of developmental capitalism. It was implied in the Africanist tendency of the ANC and of the Pan Africanist Congress (PAC). That tendency had been significant in the ANC, but always secondary, although the ANC as a whole had seen itself as akin to the anti-colonial liberation movements of Africa. The crumbling regime tried yet another option, its first, a power-sharing consociational democracy with certain veto points for the minority, but this was rejected by the ANC (Spitz \& Chaskalson, 2000).

The chosen liberal democratic option has been very successful in organising a democratic transition, probably also contributing to the far right's final abstention from armed violence. Fair pluralistic elections and an independent judiciary have given the country a relative democratic stability. The "equality clause" of the Constitution cleared the way for affirmative action of racial redress. The Truth and Reconciliation Commission was a brilliant invention in the handling of past state injustice.

However, alongside, or intertwined with, its liberal elements, South African democracy also carries important features of postcoloniality - a concept I use, on the basis of previous research, as part of the analytical framework of nationstate formation sketched above, and completely independent of all the variants cultural "postcolonial" theories. (For an overview of the latter, see for example, Ashcroft [2001] and McLeod [2007].)

\section{Postcolonial South Africa}

Postcolonial nation-states have developed three distinctive characteristics, which have endured in various forms and to a variable extent. One is their conception of the nation as a colonial product turned into a nation by anti-colonial political struggle. The boundaries and the cultural content of the nation is taken as given by the contingent and usually very arbitrary demarcations of colonial power and administration. This politically overdetermined nation has little of sociocultural cohesion and is kept together mainly by postcolonial political power. This power, and the anti-colonial movement which led up to it, therefore tends to see itself as the embodiment of the nation, tending to put limits to political pluralism, even in functioning electoral democracies such as India, with its Nehru-Gandhi dynasty and until recently overwhelming Congress Party. The political postcolonial nation is prone to continuous friction and recurrent sharp, violent conflicts between the different ethnic and religious groups bundled together in it. While not precluding movements and struggles of class, class solidarity is clearly impeded and delimited by this sociocultural heterogeneity of the postcolonial nations. 
Secondly, postcolonial polities and societies have inherited a profound sociocultural duality from the experience of colonial domination. It is most directly audible in language. The great majority of postcolonial states have adopted the colonial language as either their official language or officiously as their language of high politics, judiciary, administration and business. Unless there had developed a lingua franca prior to independence - like Arabic, Swahili or Bahasa Indonesia - choosing one native language as the national language would have triggered violent conflict. At the same time, native languages continue to be the everyday medium of communication for the majority of the population, who mostly do not master the ex-colonial language. There is then a deep cultural divide between the postcolonial elite and the postcolonial people.

This duality is also expressed in two different attitudes to the colonial experience. To the postcolonial elites, the colonial rulers were generally role models in many respects of education, religion (particularly in non-Muslim Africa), comportment, dress, lifestyle and advantages. Upon independence, the new rulers typically took over, not only the colonial positions of power, but also their rich emoluments and large servant staffs, and the ex-colonial neighbourhoods with their swimming-pools, golf courses and exclusive schools. At the same time, the new elites harboured a great deal of resentment against the colonisers for their humiliating discriminations and exclusions. This second attitude, the elites also share with the postcolonial population at large, raising recurrent demands for reparations, compensation and redress.

Thirdly, history and symbolic historical politics take on a special significance in postcolonial states and societies, deriving from the colonial denial of and contempt for the history of the colonised peoples. Often the latter were conceived as "peoples without history", and their precoloniality as "savage" or "barbarian". Moreover, the colonial conquest and the development of colonial modernity meant that the precolonial polities and societies had been defeated and overtaken. For the postcolonials, it therefore became an important task of the state and social and cultural institutions to explore, recover and create their precolonial history, and to narrate the development of the nation as colonial suffering and as anti-colonial struggle. This concern with pre-modern history may also take institutional forms, including recognition of pre-modern authority.

These three typical traits of postcolonial nation-states and political cultures have all left their imprint on post-apartheid South Africa.

There is clearly a typical postcolonial trait in the dominance and the nationrepresenting pretensions of the ANC, whose previous President thinks it will "rule fully until Jesus comes back ... we have been blessed" (Van Onselen, 2016). 
A resolution celebrating ANC's "75 years of struggle", claimed: "The formation of the ANC in 1912 signified the birth not only of the ANC, but also of the South African nation" (Turok, 2011:117). No government party in an ordinary liberal democracy would survive a series of elections presiding over an official rate of $25 \%$ unemployment (by OECD 2015:12 standards, 35\%) and with more than $60 \%$ of the vote at that, in 2019, after 25 years of not very successful governing down to $57,5 \%$. In its electoral campaigns, the ANC is regularly playing an Africanist postcolonial card against its main rival, the Democratic Alliance (DA). President Zuma used it extensively in the 2016 local elections campaign, for example: "They are snakes, the children of the Nationalist Party ... They think a black person can't run the country" (Mkentane, 2016). In spite of its impressively successful reconciliatory transition from a settler-state to a postcolonial one, the frictions, tensions and recurrent internal violence of heterogeneous postcolonial nations continue to re-appear in South Africa.

While South Africa has 11 official languages, the two colonial ones, English and Afrikaans, are the languages of the elites and the professions, and, it seems, of the schools, which do not appear to try to connect their colonial language instruction to the native mother tongue of their pupils (Soudien, 2012:153-154). The opening up of higher education to African students has brought the language issue into the conflict arena by student movements.

Equality in postcolonial countries has typically been interpreted as equality between the new elite and the former. This has clearly been an important strand, if by no means the only one, in ANC government policy of Black Economic Empowerment (BEE), and its priority to the racial distribution of top positions in all walks of society and state, over general economic and social inequality. The public governmental aim is to keep income inequality the highest in the world until 2030, as indicated by the official economic goal of a Gini coefficient of 0,6 in 2030, that is, more inequality than any other state today, except neighbouring-cumsimilar Namibia (National Planning Commission, 2011:24, 54). The African share of the country's most advantaged 5-6\%, in terms of income, wealth, housing and consumer items, has increased from five per cent in 2004 to $29 \%$ in 2014 (SAIRR, 2016:337), a change into privilege faster than the rescue from abject poverty, down by 15 percentage points (SAIRR, 2016:339). Overall income inequality, as measured by the Gini coefficient, remains about the same as in the last decade of apartheid, just below 0,7 (Leibbrandt, Woolard, Finn \& Argent, 2010:13; Ngepah \& Mhlaba, 2013:fig. 2a).

Julius Malema, when he was still in the ANC, expressed the desire for colonial or settler privilege most bluntly: "We must have everything that white people have" (Posel, 2013:68). His founding of the Economic Freedom Fighters (EFF) later also 
represents an example of the recurrent resentful demands for undoing the colonial dispensation and its persistent effects of durable inequality.

The urban duality of the settler-state is still visible in the postcolonial cities of South Africa, where a good third of the population of the capital city, Tshwane, as well as of the business centre, Johannesburg, the financial and airline hub of Africa, have no piped water at home, and about a tenth lack electricity in the second decade of the twenty-first century (Gedye, 2016a, 2016b).

Constitutional Principle XIII 1 recognised the legitimacy of traditional chiefly authority: "The institution, status, and role of traditional leadership, according to indigenous law, shall be recognized and protected in the Constitution. Indigenous law, like common law, shall be recognized and applied by the courts, subject to the fundamental rights contained in the Constitution and to legislation dealing specifically therewith." It has been estimated that about 18 million South Africans are living, to varying extent, under traditional authority (Johnson, 2015:136; cf. Oomen, 2005). This is another postcolonial duality, frequent in Africa and also occurring in Asia, for example, in Malaysia.

Thirdly, the new South Africa has invested heavily in symbolic politics. Symbolically, the postcolonial South African state manifests itself above all in the country's new national monument, Freedom Park in Tshwane, arguably the most sophisticated and elaborate national monument of the world. It is also yet another expression of the remarkable South African capacity for reconciliation after violent conflict, first manifested a century ago when the Boers, the Anglos, and the British Empire came together a few years after the extremely brutal Anglo-Boer War to set up the Union of white South Africa. Freedom Park has been laid out on a hilltop at a distance across a highway, but in sight of the grand Boer Voortrekker monument, and on Reconciliation Day, December 2011, the Park was directly connected to the Boer monument by a new road.

Freedom Park opened in 2007, with additions continued after that. It is the most elaborate, deliberated and original symbolic ensemble in modern history, perhaps ever. It is a masterpiece of postcolonial iconography, anchoring the nation in precolonial African culture, narrating its long road to a postcolonial state through violent oppression, colonialist industrialisation and urbanisation, and through heroic and ultimately victorious resistance.

It is based on Indigenous Knowledge Systems. Tribal elders, traditional healers and (indigenous) anthropological Africanists were extensively consulted and crucially involved in the design. The layout is a symbolic landscape based on African principles and expressed in concepts of African languages. It has three main parts. 
The first part that was constructed and the most distinctively African is Isivivane, a sacred place where the spirits of the fighters for freedom are resting. It is demarcated as a circle by 11 boulders, one for each of the country's nine provinces, one for the nation as a whole, and one for the international community contributing to the struggles against racism and apartheid.

The then president, Thabo Mbeki, questioned its abstract anonymity, and a new section was built, $S^{\prime} k h u m b u r o$, a Remembrance complex - including a Wall of Names of identified victims of wars in South Africa, from precolonial wars and colonial genocide and slavery to apartheid repression - and a Gallery of Leaders. The latter is divided into three categories of descending size - South African, Continental and World leaders who have contributed to African freedom. The still open list currently (c.2013-2014) mentions four names in the third category: AfricanAmerican scholar and activist WEB DuBois, Jamaican Back-to-Africa politician Marcus Garvey (who notoriously collaborated with white racists for his scheme), Che Guevara, and Toussaint L'Ouverture, the leader of Haitian independence. The South African gallery is ecumenical and includes, alongside defunct historical ANC leaders from Luthuli to Tambo, the founder of ANC's rival organisation, PAC, Robert Sobukwe, nineteenth-century Zulu warrior kings, two white anti-apartheid militants (Bram Fischer and Helen Joseph), and, upon second thought, two Boer commanders from the Anglo-Boer War, De Wet and De la Rey. ${ }^{1}$ The choice of the latter two is not quite obvious. Both participated, together with four other Boer generals, in the National Convention of 1908-1909, where De la Rey belonged to the anti-African diehards, together with the Natal delegation, who voted against the compromise of letting the Cape colony keep its non-European franchise, for the time being (Brookes \& Webb, 1962:241).

//hapo, a Khoi-San word meaning "dream", is the third major component of the Park, located in a boulder-shaped edifice. It is a museum of African cosmology as well as of history, starting with the origins of the Earth, its Peopling, the world of Ancestors and via colonialism, industrialisation and urbanisation, portrayed mainly from the angle of the exploited, going up to contemporary Nation- and Continentbuilding. (See further Oliphant, Serote \& Raman, 2014.)

1 A first list of 24 names was announced in 2009, and may be found at www.politicsweb.co.za. By 2014, there were 37 names (Oliphant et al., 2014:43), and additions can be identified at www.archivalplatform.org 


\section{Envoi}

The enormous inequality of South Africa is not a creation of apartheid racism and therefore did not disappear with apartheid. It is an effect of the racism inherent in all settler colonialism, aggravated even before apartheid by the particular conditions of South Africa, where the majority of the population was excluded, not only from most of the land and all the mining wealth, but also from the urban industrial economy fueled by mining rents. The end of apartheid has meant a profound transformation of South Africa - its state, its political and civic culture, its economy, its ethnic and "race" relations - which cannot be adequately grasped as an establishment of democracy and an abolition of racial discrimination, as a change similar to what happened in the American South in the 1960s and 1970s. It has been argued here that viewing the process as a transition from a settler- to a postcolonial state and society is more fruitful for understanding the outcome as well as what was at stake. For good, or as well as for bad, the turn of the South African society and state to postcoloniality constitutes a significant element of the stormy social laboratory the country is. 


\section{References}

Ashworth, B. 2001. Post-Colonial Transformations. London: Routledge.

Brookes, E. \& Webb, C. 1962. A History of Natal. Pietermaritzburg: University of Natal Press.

Bureau of Census and Statistics. 1960. Union Statistics for Fifty Years. Pretoria: Union of South Africa.

Central Statistical Services. 1997. South African Statistics 1995. Pretoria: Republic of South Africa.

Dorrington, R.E.; Bradshaw, D. \& Wegner, T. 1999. Estimates of the Level and Shape of Mortality Rates in South Africa around 1985 and 1990 Derived by Applying Indirect Demographic Techniques to Reported Deaths. Cape Town: MRC Technical Report.

Gedye, L. 2016a. Tshwane voters may turn on ANC. Mail \& Guardian. 15 July.

Gedye, L. 2016b. North, south, east and west, throw your hands up: Jo'burg residents despair of crime. Mail \& Guardian [Online]. https://bit.ly/36YKig1

Giliomee, H. 2014a. Afrikaner nationalism, 1875-1899. In: F. Pretorius (ed.). A History of South Africa. Pretoria: Protea Book House.

Giliomee, H. 2014b. Afrikaner Nationalism, 1902-1948. In: F. Pretorius (ed.). A History of South Africa. Pretoria: Protea Book House.

Giliomee, H. 2014c. Adapt or die. In: F. Pretorius (ed.). A History of South Africa. Pretoria: Protea Book House.

Grobler, J. 2014. State formation and strife, 1850-1900. In: F. Pretorius (ed.). A History of South Africa. Pretoria: Protea Book House.

Hirsch, A. 2005. Season of Hope. Scottsville: University of KwaZulu-Natal Press.

Holland, H. 2012. 100 Years of Struggle. Mandela's ANC. Johannesburg: Penguin.
Johnson, R.W. 2015. How Long Will South Africa Survive? Johannesburg: Jonathan Ball.

Leibbrandt, M.; Woolard. I.; Finn, A. \& Argent, J.B. 2010. Trends in South African Income Distribution and Poverty since the Fall of Apartheid. OECD Social, Employment and Migration Working Papers, No. 101. Paris: OECD Publishing. https:// doi.org/10.1787/5kmms0t7p1ms-en

McLeod, J. (ed.). 2007. The Routledge Companion to Postcolonial Studies. London: Routledge. https://doi. org/10.4324/9780203358085

Marais, H. 2001. South Africa: Limits to Change. Cape Town: University of Cape Town Press.

Mkentane, L. 2016. DA are snakes: Zuma. Sunday Independent [Online]. https://bit. ly/2FTOUYL

National Planning Commission. 2011. National Development Plan 2030: Our future - make it work. Pretoria: National Planning Commission. https://bit. ly/3aUbpeB

Ndebele, T. 2016. Demographics. In: SAIRR (South African Institute of Race and Racism) (ed.). South Africa Survey 2016. Johannesburg: SAIRR.

Ngepah, N. \& Mhlaba, S. 2013. The role of South African government policies in economic growth, inequality and power. In: U. Pillay, G. Hagg, F. Nyamnjoh \& J. Jansen (eds.). State of the Nation: South Africa 2012-2013. Cape Town: HSRC Press.

OECD (Organisation for Economic Cooperation and Development). 2015. OECD Economic Surveys. South Africa. Paris: OECD.

Oliphant, A.W.; Serote, M.W. \& Raman, P.G. 2014. Freedom Park: A Place of Emancipation and Meaning. Pretoria: Freedom Park. 
Oomen, B. 2005. Chiefs in South Africa. Oxford: James Currey. https://doi. org/10.1007/978-1-137-06460-8

Posel, D. 2014. Julius Malema and the postapartheid public sphere. Acta Academia, 46(1). https://bit.ly/2RrB3OQ

Pretorius, F. 2014. Everyone's war: The AngloBoer War (1899-2002). In: F. Pretorius (ed.). A History of South Africa. Pretoria: Protea Book House.

SAIRR (South African Institute of Race Relations). 2011. South Africa Survey 2009/10. Johannesburg: SAIRR.

SAIRR (South African Institute of Race Relations). 2016. South Africa Survey 2016. Johannesburg: SAIRR.

Sheridan, J. 1972. From protest to challenge. A documentary history of African politics in South Africa 1882-1964. In: T. Karis \& G. Carter (eds.). Protest and Hope 1882-1934. Stanford, CA: Hoover Institution Press.
Soudien, C. 2012. Realising the Dream. Cape Town: HSRC Press.

Spitz, R. \& Chaskalson, M. 2000. The Politics of Transition. Johannesburg: Witswatersrand University Press.

Therborn, G. 1992. The right to vote and the four world routes to/through modernity. In: R. Torstendahl (ed.). State Theory and State History. London: Sage.

Therborn, G. 2011. The World. A Beginner's Guide. Cambridge: Polity.

Thomas, C. 2014. Coloureds: A complex history. In: F. Pretorius (ed.). A History of South Africa. Pretoria: Protea Book House.

Turok, B. (ed.). 2011. Readings in the ANC Tradition. Auckland Park: Jacana Media.

Vahed, G. 2014. The Indians in South Africa. In: F. Pretorius (ed.). A History of South Africa. Pretoria: Protea Book House.

Van Onselen, G. 2016. ANC exhibits all the signs of deep denial. Business Day [Online]. https://bit.ly/389If8X 
SECTION II

\section{ASSESSMENT AND \\ FUTURE PROSPECTS}

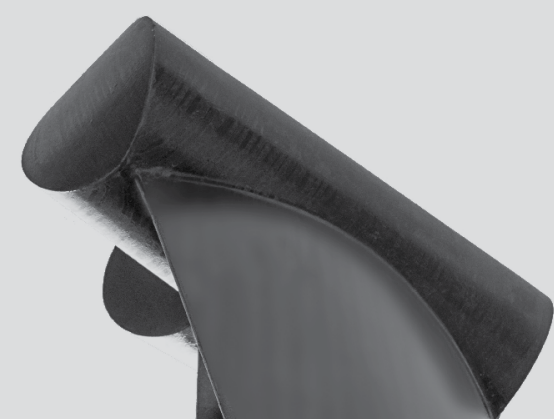



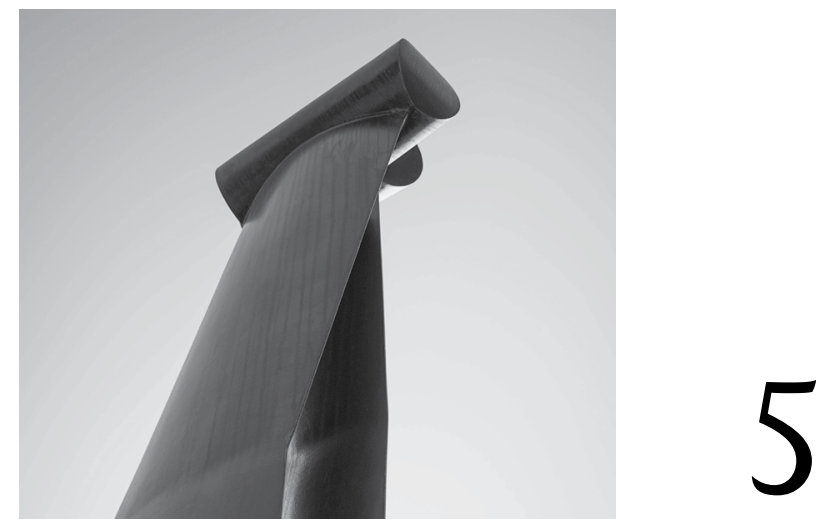

\title{
WAYS OF BEING
}

"Race" as common sense; non-racialism as humanist necessity

\author{
Gerhard Maré
}

Introduction: From here to there

There are so many ways in which race continues to be accepted as the essential and predominant explanatory tool in social life. There are probably as many reasons that are, and can be, advanced for groups living through racialism. But, if questioned, explanations would not always be easily forthcoming: common sense acceptance removes the need for reflection - why does the sun rise every morning? Surely it is presumptuous, and even insensitively condescending, to suggest that such a state of affairs has to be challenged, never mind deliberately undermined? As specimens of a category, as it is with all such constructed groupings, means not only being born into, but also with "specimendom". However, driven by historical and contemporary knowledge of the effects of simply accepting the status quo of social identities, I will argue why each one of us has the obligation to question such common sense, even desirable and desired, way of being. The most important motivations for my argument relate to the gross effects on personal and social relations, and how racialism and consequent racism obscures the full complexity of global problems 
humanity experiences at local levels. We are in this together, whether we like it or not. The "small blue dot" will survive without us, but let us destructive humans at least try to be part of it.

\section{But where to start?}

There is the story - often told with variations on a common theme - of the person lost, asking for directions, and after listening to several attempts to explain many routes is told "No, you can't get there from here". Then there is Rebecca Solnit A Field Guide to Getting Lost (2006) - making the case for questions, deliberately being in the unfamiliar, because that demands confronting the unknown, and not just accepting apparent (selfish) certainty. There remains also Rick Turner's argument for an imaginative journey through utopian thinking towards creating a world beyond the apparently unchanging social relations that exist $(1972 / 2007)$. I unapologetically return here to issues that have concerned me over decades since the 1970s, and unfortunately seem to be more relevant by the day - fortunately I am not alone in these concerns, and I pay respect to some of the fellowtravellers - some who have died in the struggle to question and argue for a very different world.

\section{Here}

Who would have thought that some 60 years later I would personally be confronted daily with the real possibility of nuclear devastation - then a scratchy news film item, now two warped immensely powerful men slinging insults and threats? Who could have imagined that human responsibility for extreme climate uncertainty and global extinctions would be denied against scientific evidence - at times because it is scientific? To bring it home, who would have imagined daily race classification in a democratic inclusive South Africa? No, you can't get there from here.

However, this is where we are, with the responsibilities that it brings. I present my understanding of the here and now, in respect of one small, but important to millions, aspect of the big social picture: "race", "racialism" and "racism" in twenty-first century South Africa. We have to address the continuation of the notion of "race", living through racialism, and confronted with racism. "Race" operates frequently, in many societies, as an ideological element in meeting social, economic, and political needs. It is also claimed existentially as essential in being human in distinctively culturally rigid ways. However, I argue that, whatever the need expressed, race is an obstacle to be overcome because of the unavoidably destructive consequences of its existence, employment and deployment, towards whatever ends. In such an approach, "race" can obviously not be addressed in isolation from historical socioeconomic, political, and existential contexts. 
The past we have to understand, in its complexity and consequences; doing so in critical ways that allow us to be in the present as active, engaged citizens; with imagination and sense of moral engagement and social responsibility, confidently to work collectively towards a desirable future. All too obvious when it is put like that.

Maybe the most challenging question surrounding civic engagement and action is, first, honestly to address "why" it needs to be undertaken, at the social and personal level. I put forward reasons, but the question ultimately demands that we perceive and confront the obligation to step out of false security, or fatalistic belief that change is not possible. Discomfort has to encompass not only the material boundaries set by race - a grim reality for the majority or large minority of citizens in racialised and racist societies - but also to disturb the cognitive, the sensemaking of what is around us and hence our capabilities within it.

Discomfort raises not only the need for change, but also the concomitant need to imagine a utopian future in the sense that it speaks to all as a desirable goal, even if it does not convince most in the moment. Social action here refers to collective action as well as action within and acceptance of socially shared space; it demands acknowledgement of shared humanity and also the differently experienced responsibilities that go with that from multiple locations; it requires a notion of involvement beyond the power of individual desire.

\section{What}

In this chapter, I accept the challenge of "it is not possible to get there from here". I do it because, as I tried to warn in relation to ethnic mobilisation some decades ago, not to take the unclear alternative route since it carries with it horrifying consequences. I do so by disentangling and re-entangling terms, calling for their contextualisation by posing the "why" and the "how" questions, with suggestions of the "what" of a motivational goal.

However, any goal requires conceptual clarity of the need for distinguishing between "race", "racialism", and "racism" - what should we escape - but also the manner in which they exist, function, and articulate in society. This last point is crucial - "race" can be looked at in isolation from any expression of the belief only if perceived and accepted as a biological fact. Otherwise it exists and can be understood only as a human created and deliberately maintained sense-making element, in sociopolitical, spatial and historical context, entangled with other social processes, beliefs, and structures. At times, religious or cultural beliefs are essential to justifying race-thinking, often we have to explore power and class relations to make sense of its continuation. 
The STIAS project, Effects of Race, where my writing takes place, uses the summary word "race" in the English language. Even if project members, including myself, may have operated within several first languages, we have not drawn attention to the implications for social analysis. I understand "race" to refer to the specific categorisation of humans into putative biological groupings (called "races" or various euphemistic equivalents). It is a powerful socially constructed perspective on the world within which we still find ourselves. It has been subject to alteration, adaptation, and to a variety of justifications and uses since the time of creation and first employment - its reproduction ensured by those with power and means to do so. For example, the specific understandings of how to distinguish between races, and hence the meaning of the word, has changed over time, even if not in essence then at least in significant emphasis. In its first use, it was applied on the basis of appearance, which effectively overlapped with geographical location, and was shaped by who did the initial labelling of whom, also reflecting inequalities of power expressed in various ways.

In addition, various explanations have been given for the existence of human racialised diversity in appearance, culture and modes of life, such as the powerful Christian call on the story of Ham; definitions of "civilisation" from specific perspectives; or the might of the sword or the gun in the creation of empires and subjugation of people. Especially during the nineteenth and first half of the twentieth century, social Darwinist "scientific racism" provided explanation with focus on the measured body, in its outward appearance and proportions, and internal constitution to provide evidence of unavoidable biological difference (Malik, 1996:90-91; Dubow, 1995; Walters, 2019). Race allocation served to prove a hierarchy of evolutionary progress and "intelligence" and attributes associated with those terms, and allowed specific treatments. More recently, a biocultural approach dominated such as during apartheid, with the stress on ethnic aspects of race differentiation along with the always-present biological. It continued to imply evolutionary justification, with progressive gaining of abilities, in preferably separate spaces. With the genome revolution, there have been attempts to use the existence of genetic populations to confirm notions of race distinctiveness. This runs against the predominant genome proof of the fallacy of such distinctions as "races" as the continuation of what had been thought to exist historically (Fields \& Fields, 2012). "Race", as concept and focus of research, is operative especially in the academic/intellectual field where questions are asked and arguments developed. Maintaining "race" always has a purpose and justification.

Racialism or race-thinking refers to a variously shared understanding amongst many humans that races exist, as part of "being human today", with a variety of ways in which cognitive proof is found - we "think" race, but the idea is already present. It refers to the actions (at every level, and not only at the personal) that are informed 
by such understanding as well - we operationalise our thinking, attaching race labels all the time in practises. This refers then to the common sense (racecraft), the ideological existence of race as everyday. The variety of contexts demand investigation of the processes through which the ideology of race is produced, employed, and operates, as well as where it is (or could be) undermined. Again, historical change, political location, and personal variation in such thinking, are essential dimensions to include. Processes of socialisation and mobilisation, and template creation lie at the core. Actions that flow from racialism are, in some cases, claimed as innocuous and even essential to well-being - in cases where race is thought about and not just with.

What I have not mentioned directly, except in passing, is the reason why racethinking should be so powerful. I acknowledge here a book important in my own thinking, namely Kenan Malik's The Meaning of Race (1996:5; see Maré, 2017:149-152). Malik argued throughout that "the creation of a race is the product of social need, not biological fact". Hence, as the social changes, so the need shifts; and as the creation changes so it, in turn, affects the social world. For example, in South Africa the templates of race continue from apartheid to post-1994 democracy, but the needs demand different formulations of justification with different effects. To put it in a different way, the relationship power - ideology shifts.

Non-racialism, in the manner I conceptualise it, refers to challenging and rejecting "race" as referring to essential (natural) recognisable human groupings (for a fuller discussion, see Maré, 2014:130-149). It does not mean colour-blindness, a nonsensical claim for anyone seriously combating racism and racialism; nor does it deny the power and historical and contemporary effects of the construct "race" - quite the contrary.

Finally, racism refers to the attribution not only of relatively benign characteristics through racialism, captured by the frequent soft and obfuscatory employment of "diversity" instead of "multiracialism", but of degrading and always hierarchical attributions to members of races. This can range from denial of shared humanity to such labels as uncivilised, unintelligent, sexually promiscuous, disease bearing, amoral, etc. In this extreme form, it comes with personal and social consequences that psychologically degrade and may result in physical or material harm, even death and genocidal annihilation. Racism, the largely rejected social scourge, is but the extreme form of racialism, which serves as the bedrock of the former.

Keeping that distinction in mind - between the three easily and often synonymously used terms - is essential to any attempts to overcome the effects of all three. In South Africa, the notion of non-racialism is frequently also expressed as nonracism, revealingly misquoting the Constitutional commitment to "non-racialism and non-sexism". 
What is always at work in discussing and defining all three terms is classification: races, racialism, and racism do not exist without such allocation. It is a social construct for purposes. The categorical - in both senses of the word - allocation of groups of human beings, formally and informally, into putatively pre-existing constructed groups determines the unambiguous essence of every "specimen" of the category - whether "blacks", "whites", "Zulu" or any other. In addition, the category that is my first concern here, "race", has extreme effects and extensive uses, albeit often existing as banal common sense.

It is essential that the social construction and its effects be located within a wider context, within which it features with various degrees of relevance to its maintenance and employment. What importance should be granted to race? I have recently grappled with the implications of such a question in writing about race and inequality (Maré, 2017). Does race cause resource inequality? I suggested there that "race" (including racialism and racism), the name which is the construct, is to be seen as useful - even essential - in ordering social life and in its effects: firstly, in justifications (for forms of exploitation, domination, and distribution of goods and values, and hence features in templates of race) (for discussion of templates see Alexander, 2007; Maré, 2018). Secondly, it plays a major role in providing obfuscatory explanations hiding the manner and who benefits from racialism, and thus delays and even avoids effective measures to address social issues - such as inequality, as Fields and Fields argue (2012). And, finally, it can be linked with a range of context and time specific direct effects/consequences. This approach is necessary against one that sees race as the cause of much that is claimed can be addressed only, or primarily, through measures employing the very construct, such as proportionally equalising races (deracialising capitalism in South Africa), improving "race relations", or providing worth to actually divisive social identities.

In other words, to combat race in its use as an instrument and to avoid the trap of objectifying the phenomenon, it is essential to confirm the term as a social construct with original and subsequent ultimately disastrous negative effects, one which needs explanation in every discussion of effects. Not for one moment should accusation of devaluation or avoidance - for that is what it is perceived to be by many, such as through the accusation of "colour blindness" - deflect from the horrific effect of the employment of and mobilisation through the construct. Instead, it provides the very reason why its continuation, in whatever form, needs to be subjected to intense questioning, as well as actions towards separating it from its claimed essentialist existence. It carries the violence, humiliation, and dehumanisation of centuries with it. 
Why?

Should the world, never mind South Africa, not be content just with improving "race relations"? Why want to do away with a social construct that is there because it met and meets social needs? I have in part already given an answer, even if I still need to convince you. Its dehumanising effects on the individual and group, where Bauman's argument of turning individuals into specimens of the categories to which they have been allocated (Bauman, 2000), should be enough - but it clearly is not. Race-thinking's daily practitioners include many whose moral arguments and beliefs are discarded, adapted or put on hold in the interest of not rocking the boat; or in meeting the requirements of those in power; or of sensitivity to presentday identity politics of race. The belief that it can be employed for positive reasons, and thus effectively confirmed and maintained, can easily be illustrated, with South Africa being simply one of the recent entrants. It is also a vivid example of how such use fails in its ostensible positive outcome. Elsewhere, such as in Brazil and the United States, the failure of such an approach, of clinging to race, to address inequality, and the effects of its categorising practices, are equally clear. The way in which it deflects, in its immediate day-to-day obviousness, to such catastrophic dangers as climate change and to the central cause of inequality, namely capitalism, is there to ignore. It suits the powerful that they be ignored.

The immediate answer lies in the vehement rejection of acceptance - of race, racialism and racism, as above questioning, by anyone, anywhere; it lies in efforts to critically examine the conditions that maintain inequality in its expanded sense (Therborn, 2013), and to work towards addressing such conditions in small ways; to confront climate change in a similarly cumulative manner, and through personal life choices. My commitment is to exploring, understanding, and tackling not only the vicious operationalised effects that the term race always carries with it, but also to explore its existence and employment as the very effective obstacle in the way of dealing with real concerns of existence - of survival, actually, for most global citizens.

There are, surprisingly it would seem after apartheid, more and more calls in post-1994 South Africa for the valuing and retention of race, not only as a statedriven template, but also as an organising principle of social action and interaction. The calls could be multiplied if taking into account, in addition, such racialised notions as "identity", “victimhood”, “our due”, "ethnicity”, “culture”, "minority”, "majority”, "biology”, “indigeneity”, “nation”, “patriotism”, “civilisation”, "settler”, "transformation/redress/affirmative action/empowerment", "revenge", and so forth. They are all held together by an identity of "us" (and hence of "them/they", or more directly "you"), shaped already and increasingly by biological or pseudo/faux/ 
near-biological ideas of essences. Each can also be extended by looking at the essential attributes that come into play from within and from without, or are implied, when the terms serve as explanation, justification, mobilisation, rejection, denigration, etc. Apartheid truly lives on in ways that were seen as abhorrent by all progressive forces under its vicious and all polluting rule. "Race" rules out shared responsibility for addressing local expressions of global issues.

Of course, looking back, some of the signs of what was to come were there, before, during and after the transition in 1994: race nationalism (from the white far right and from radical right Africanist voices); "tradition" openly demanded and fought for (especially as claimed from the KwaZulu Bantustan, but then confirmed as desirable continuities for the country); and with capitalism defined as something to be invaded and captured, made "ours", rather than subjected to intense scrutiny after the fall of communism and of apartheid. In addition, the institutional arrogance that typified the African National Congress (ANC) during the transition continued. It was embedded, in part, out of necessity to keep on claiming sole legitimacy in "the struggle", and in large part essential to claim an exclusive right to define what exists, what is good and desirable, and what is possible (Therborn, 1999), even if limited in terms of morality. This has been aggravated, especially since 2007, through an approach of (race) majoritarianism to democracy itself - an absurd description when race statistics indicate $80 \%$ "black African" population. How can racialism remain the new "honour code", when it is so clear that it was presented as such under apartheid; blessed then, as it is now, through Christianity. Why is it not a code of dishonour when held post-1994?

In summary, the answer to "why", in this case, relates to the all-too familiar horrifying examples of the consequences of the creation and retention of any notion of essentialised putative human categories (from genocides based on race, ethnicity, nation, and religion), and the opportunities lost through the blinkering or blinding effect of such categorisation. What I write here is, in most ways, simply a reminder of the point made by Neville Alexander in the concluding chapter, "Enough is as good as a feast", in his Thoughts on the New South Africa, published posthumously in 2013. He refers there to the

sincere, indeed naïve, belief in the values of freedom, equality, solidarity and democracy, which drove all of us in the decade of the 1980s, [and which] has been systematically eroded by the irruption of the narcissistic, dog-eat-dog virus that is spreading across the globe ... [A]gainst this backdrop ... I want to put the spotlight on the question of whether it is possible for us to 'return to the source', to borrow an exhortation from Amilcar Cabral - that is, once again to place at the centre of our vision, our plans and our behaviour the values on the basis of which we hoped to build the non-racial, democratic republic after the demise of apartheid capitalism.

(Alexander, 2013:189) 
Let me state, without fudging the issue, the "there" I have in mind cannot be contained through addressing certain aspects of race, racialism and racism (such as through legislation against racism, or public naming and shaming - necessary as that might be). It needs to be informed by an interlinked response, at all levels of society aimed at the various dimensions of race in its everyday existence as racialism and racism, and by refocusing on shared problems to be collectively addressed. It could never succeed through a focus only on the direct expressions and maintenance of racialism, abhorrent as that may be. The goal of a non-racial society must be investigated, theorised, and acted upon as an essential dimension of inequality, and through collective action against other global problems. It is necessary as part of a strategy towards "enough", within which the demise of capitalism as it exists is core. Instead, the focus should be the ongoing investigation of alternative systems of production and consumption, and other measures of performance (Fioramonti, 2013). Forms of economic structure, in turn, relate inextricably to environmental effects, and thus social responsibilities. The non-racial utopia in this social formation, and many others, effectively means a future of "enough" - the one is intimately linked to the other, not, however, in the redistributive racial approach that dominates post-1994. This not to imply that the political and ideological are simply reflections of economic systems - they function in relative autonomy; but at the same time ideological change is only made possible if economic systems alter, with fresh possibilities (and demands) for human interaction.

In the primary focus of the Effects of Race Project, and thus the goals addressed in this chapter, racialism and racism exist as major obstacles in themselves, and as concomitant to addressing inequality. There can never be serious commitment to "enough" - the "feast" that has to include the $99 \%$, for it to have any meaning - while we are distracted and even prevented from addressing inequality through wrongly and partially attributing cause and effect. Side-tracking is possible because race is real in its consequences, real in its multiplicity of interferences, in its desirable presence (for some), in its functions as "racecraft". Racialism is to be rejected in its essentialised maintenance and employment. Barbara Fields and Karen Fields draw attention away from just the emotionally-charged issues of racism to link racecraft to the effective, even if not always deliberate, avoidance of dealing with inequality, of obscuring "the intimate interaction between inequality and racecraft ..." (Fields \& Fields, 2012:16).

In relation to the specific focus addressed here, the future, if it is to be liveable, has to lie beyond the categories, beyond just race, of hierarchy, of essentialism, of what undeniably facilitated hatred, inequality, violence and extermination in the past, and continues to do in the present. Here too it sounds so simple and obvious: the 
"beyond" is one of human solidarity, under whatever name. Paul Gilroy appeals to accepting that "beyond the corrosive power of racial categories", lies "a more substantive human commonality" (Gilroy, 2010:64). However, that notion of "human commonality", if it is in any way to be an attraction, an alternative to the clear value that racialism and racism holds for those in power or desiring power, will have to be clearly linked to a collective project, a democratic project, that mobilises those whose equality lies in striving and achieving in resource, vital and existential fields. The scale of such a task demands flights of utopian imagination, and mobilisation, requires an escape from what exists. Gilroy again, drawing on a Fanon that is rarely heard in the cacophony of selective claims:

$\mathrm{He}$ [Fanon] directs us to the costs for both victims and perpetrators of operating in an 'epidermalised' social and political environment where any common humanity is 'amputated' and authentic interaction between people becomes almost impossible.

(Gilroy, 2010:157)

In summary: expressing and working towards the utopian goal of equality, as captured by "Enough is as good as a feast", and drawing on analysis and action in the three fields proposed by Therborn (2013) - resource, vital, existential inequalities - is already required of us. The need will intensify as socioeconomic and environment-related conflicts intensify, creating conditions that make it impossible to maintain exorbitant life for some - unless through even more extensive policing and exclusion - and misery, starvation and migration for the overwhelming majority. The role played by racialism and racism in hiding and deflecting attention from shared concerns, a role with its own consequences as mentioned above, also means that these readily available and embedded constructs of social categorisation serve as the obvious ideological support for race-populist mobilisation in times of local crises. Examples abound, here and elsewhere.

\section{Recognition of the obstacles}

Confidently describing the "how" of de-legitimating, invalidating and refuting the common sense of racialism, is a near-impossible task. It is a contest against the historically accepted social vision and experience; against those who directly benefit from its maintenance - and it is still capitalists; against those who are led to believe that racialism can be inverted in its effect of oppression - "using the tools of the oppressor". However, at the same time there are also aspects of society, arguments and experiences to call on that can strengthen the case in South Africa.

The most pervasive obstacle is racialism as ideology - the manner in which a social construct, a term and a system created by humans, is turned into and maintained as valid to "being human today" through ideological power. Hence, the most appropriate theoretical approach is to analyse it as ideology; and here, once 
again, I turn to Therborn's argument in The Power of Ideology and the Ideology of Power (1999). He offers an approach that sees ideology as constructing two kinds of subjects - the first through subjecting individuals to ideologies, and the second to construct ideological subjects accepting notions of what exists, what is good, and of what can be achieved (what is possible). In each case, it implies the opposite as well - for example, presenting what is undesirable, and what impossible to achieve. In each case, it implies that those with power create and maintain ideological content to their benefit. Ideology works, through interpellation, in its call on people to live their lives as specific kinds of subjects. Ideologies do not change rapidly, but are reproduced in large part by drawing on prior knowledge and a "prior vocabulary." Brian Fay uses that term in a way that is worth noting - he draws attention to "facts" and their use. In much of the world, what has been constructed, "race", has become fact:

Note here that it is never phenomena themselves which are the facts but phenomena under a particular description. Facts are linguistically meaningful entities which select out from the stream of events what happened or what exists. But this means that in order for there to be facts at all there must be a vocabulary in terms of which they can be described. Without a prior vocabulary which a describer brings to a situation there would be no facts whatsoever.

(Fay, 1999:73, emphasis original)

Ideological construction of the social world takes place through words, a language that tells us the "facts" of "what exists". This explains also why there might be variations in the words and the races. South Africa still has four.

We are born into systems of thought, captured in words, and not only social structures. Because of the embeddedness of certain ways of seeing the world and acting in it, Kwame Anthony Appiah examined remarkable occasions when "honor codes" of approved social behaviour change fairly rapidly, when what seems irreversibly "good" loses its value and what had seemed impossible become achievable (2010). Colonialism and subsequent systems of domination and exploitation, globally, ensured that we became race subjects. Apartheid built on and adapted such prior knowledge, of belonging to races, knowledge already shared by oppressor and oppressed. We are stuck in a racialised world, until ... that is what exists. This the core acceptance required by any successful ideology, certainty about the world as it is described and lived and apparently required by $u s$ to be "comfortable". We have been subjected and become specific kinds of subjects racialised in this case.

That certainty is also reinforced through structural and organisational forms. What exists and is promoted with vigour, are formal and state-driven templates of capitalism and race. This project, post-1994 South Africa, for example, requires race classification and the equivalent of "race classification boards", and to put a 
firm stamp of approval on capitalism! The benefits of race classification in the distribution of profit and of posts in the capitalist system ensure the maintenance of the practices (for examples see Maré, 2014). There seems to be absolutely no chance in the foreseeable future for any change at the level of state templates, the army of practitioners, and of direct beneficiaries - both willing and reluctant. In addition, the ideological ether (the stink?) of race-thinking envelops the social formation. However, debate around, research into, analysis of, clear and convincing theorising, and making use of many spaces available are, and should be, employed towards disturbing what exists as common sense. Racialism allows the hardly noticed use of race labels to be everyday discourse, and not only in media, social or other, but also in daily conversation, teaching and lecturing, conversations in public spaces. ${ }^{1}$

However, there are also aspects of society that can be advanced to strengthen the case of undermining the construction "race". In South Africa, there are many, amongst which: first and central, the successful end of apartheid, a prime historical example of formal and oppressive racialism and racism, in favour of a democratic, "post-apartheid" society. I cannot use "post-apartheid" as an unqualified descriptor, for reasons already presented: the continuities of racialism, capitalism and tradition, in their present expressions do not justify using the prefix "post" in any unqualified way. However, it has meant, in the inevitable racialised terms, that "black Africans" (four-fifths of the census category) are in political, ideological, and social control, with the opportunity, for all, still, to create a truly human society.

Second, the Constitution of 1996, no matter how neglected as a shared goal, commits citizens and the state to "non-racialism and non-sexism". Regular lipservice is paid to "non-racialism", retaining the term in what should exist, if fictional in claims for what does exist.

Third, the use of race ostensibly to create an equal society, one in which "enough" drives thinking, is failing miserably, ensuring the continuation of despair for millions. The goal remains, but the means have to be changed drastically, away from the belief in race as foundation for achieving equality. The demand for austerity, from below, will ultimately serve as that challenge.

Fourth, a perception of what it means to be human, beyond greed and consumerism, lies to be explored and claimed. It will be articulated from beyond racial dehumanisation, and even notions of human rights, which at present are largely left to the powerful to formulate and ensure.

1 The extensive archive of clippings around race, racialism and racism is being integrated into a collection at the Historical Papers collection at the William Cullen Library, University of the Witwatersrand (also see Maré, 2014:49-52). 
And fifth, class-based theorising and social action offers a powerful alternative that has to be rediscovered and revived. It dominated South African struggles against apartheid, it lives in many memories and expressions, cultural, political and organisational. Whether in religious, trade union, artistic, and other forms, postapartheid carried commitments other than race. What they shared was a collective vision of another world, beyond the apparently immovable racist system. Where is that collectivity in the twenty-first century? It is there in understanding of and responses to the multiple effects of inequality and climate change, challenges that can be tackled in multiple ways, under a shared imagination of what needs to be. This argument is also clearly made by Ian McQueen, reflecting on activism under apartheid (2015). He concludes: "There are signs, ..., that the 1970s are resurfacing as a sounding board to test alternatives to the current status quo. History may serve as a lesson, though, that these movements have to find viable ways of confronting the powerful force of populist nationalism."

Such "viable ways" may well lie in the deliberate call for an "honour code" that does not rely on race, but on notions of humanity; one that does not shy away from confronting the massive problems facing South Africa and the world, but calls for innovative thinking and collective mobilisation and action; for structural as well as ideological change. Appiah describes "honour codes" as going beyond an individual sense of morality. At the end of his book, he says: "It takes a sense of honor to feel implicated by the acts of others" (2010:204). At the beginning, he wrote: "To care for your honor is to want to be worthy of respect." Honour lies in both giving and receiving respect (2010:xviii, xix). Is it worthy of respect to hold on to racialism, never mind racism?

Part of that discomforting honour code that needs to come into effect, I argue, lies in the recognition of the "entanglements", as Sarah Nuttall described this much neglected dimension of any social formation (2009). It has been referred to by Dave Haslam, after the 2016 Bataclan shooting in Paris, as the "grey zone":

Islamic State literature talks about a 'grey zone.' Originally the phrase was used with reference to Muslims who live happily alongside their neighbours of all faiths and types. Now it can be more generally applied to any space (social, cultural) where views find common ground. Islamic State wants a world without ambiguity, a world of binary choices. Their stated aim is to foment conflict and destroy the grey zone. An extreme response is exactly what Islamic State wants. A growing zone of coexistence is their biggest fear.

(Haslam, 2016)

It is such that those who benefit from upholding race also fear. The grey zone has also to include critical thinking on patriarchy, masculinity, tradition, nation, religion, and on humanity's central responsibility as part of nature. 
One would have thought that the "entanglement" facilitated by social media would increase existential proximity and recognition - however, while certainly extending communication beyond imagination it has also fixed views and identifications, and allowed the wide distribution of insult, mobilisation (for the good at times), distribution of false news, labelling, and more. Silos of difference, silos of confirmation of difference once within them, flourish. Restricted, constricted, blind to all but what is shared within the ideological space - an anti-social media it frequently is. I grant that this is too extreme a statement, because there is so much diversity, rather than just difference, so much intimacy in our lives. But can be seen only if the blinds of certainty are lifted.

\section{Conclusion}

Hopefully I have made it clear that to address race, racialism and racism requires a complex approach, multidimensional in what is included, and multidimensional in what is proposed to counter its deplorable existence and effect in policy and daily life. Kenan Malik confronted the issue of resistance, revolt, in a piece published soon after the Manchester, UK, bombing (2017):

One answer may be that, as an individual, I possess a moral compass that Abedi or Khan [two of those involved] did not, which guides me away from such ideologies and from committing such barbarous acts. That may be a comforting thought for me, but the problem cannot be dismissed so simply. The difference is not just one of individual morality - it is generational too.

It was that last sentence that immediately drew my attention. Much is made of the unproblematic, selective and decontextualised cut and paste of what Steve Biko said in select written form (and why only him of his time); and of what Fanon wrote, slotted into the present, most often as simple confirmation and justification rather than contextualised understanding. Malik wrote a recent book on "the quest for a moral compass", informing his personal note in the response, as a Muslim, to the Manchester terror. But his book ends with the acknowledgement that the clarity that religion claimed for providing direction during various periods over the past centuries no longer applies for many, if not most, on the globe today. "Today we require such comfort [as religion historically offered across the world] because we have lost faith in our ability to be moral cartographers ... The human condition is, however, that of possessing no moral safety net. ... It can be a highly disconcerting prospect. Or it can be a highly exhilarating one. The choice is ours" (Malik, 2014:344). I would add that the challenge is ours. A position on racialism is centrally a moral one; accepting a life shaped by a construction is after all is a matter of choice. 
But is that morality to be located in race? Malik responds to this argument: "It is not progressive politics that gives shape to contemporary disaffection but the politics of identity, which, over the past three decades, has encouraged people to define themselves in increasingly narrow ethnic or cultural terms" (2017).

The "progressive politics" to which he refers in his response is captured thus, as is social identity formation. It is worth presenting it at some length - and note the sources:

The institutions that [historically, in the UK] shaped what are now called 'Muslim communities' were not mosques, but secular and political organisations such as the Indian Workers' Association and the Asian Youth Movements. [see Malik, 2012] The struggles of Asian communities were intimately bound up with wider working-class struggles. Migrant workers were at the forefront of industrial action, from the first significant post-war 'immigrant strike' at Red Scar Mill ... when Asian workers took action against the practice of forcing non-white workers to work more machines for less pay, to Grunwick ... where in 1976 black and Asian women went on strike for more than a year, demanding union recognition ... the first dispute of black workers that attracted mass support from the trade union movement.

This history provided the grounding for the struggles of my generation. We recognised the commonality of values, hopes and aspirations that bound together Asians, blacks and whites. Organisations of the left and of the labour movement provided us with the vehicles to give grievance a political form and the mechanisms for turning disaffection into the fuel of social change.

I was drawn towards politics by my experience of racism and politics [which] made me see beyond the narrow confines of racism. I came to learn that there was more to social justice than the injustices done to me and that a person's skin colour, ethnicity or culture weren't guides to the validity of his or her political beliefs. Through politics, I was introduced to the Enlightenment and to concepts of a common humanity and universal rights. I discovered the writings of Marx and Mill, Kant and Locke, Paine and Condorcet, Frantz Fanon and CLR James.

But let me return to concluding the task at hand: first, the points made about the distinction "race", "racialism", and "racism" need to be factored into research, analysis, and suggestions for interventions. Second, the various levels at which the issues of race operate need recognition and foregrounding in suggestions for intervention - state templates obviously need policy work at a national level, but personal perceptions and ways of living need more dispersed attention, from the social to the interpersonal. Third, the articulation of racialism and racism with social justice more widely than the race issue, with inequality addressed more widely than the core resource inequality, with imagining a future, inclusive of the shared projects that we need to undertake collectively, has to be at the core of thinking 
and action. To call on Malik for a final time, he writes: "In an age in which antiimperialist movements have faded and belief in alternatives to capitalism dissolved, radical Islam [or radical race essentialism, in the case addressed here] provides the illusion of being part of a global movement for change" (2017). What should that "global movement for change" mean for humanity and for our small part in it here on the southern tip of Africa? How do we factor race, racialism and racism into that wider demand?

Race is employed and exists and is reproduced under different conditions, towards various ends, and redress should, therefore, take this into account. The alternative, claiming race as the basis for all corrective action, leads nowhere, starting as it does with acceptance (gleeful in some instances, expressing a need for security in others, but also revengeful and blind to its always vicious consequences) of the biological fixity of the very construct of race - it had been done before and will continue to be done, albeit for different reasons and with different epistemologies.

Certainly opportunities have been lost, here too. In the United States, such a moment was identified in the 1967 Supreme Court case of Loving $v$ Virginia, which "invalidated state laws ... that restricted interracial marriage." A New York Times editorial comment, 50 years later, notes:

The legal scholar Dorothy E. Roberts argues that the court had all the evidence it needed to find that the racial claim underlying Virginia's [the USA state] law was scientifically invalid - and so arbitrary as to be unconstitutional - and that the justices missed the opportunity to refute 'the validity of race as a biological category.' Had the court taken that approach, the Loving decision might well have been a more enduring strike against white supremacy - and changed the way the country talks about race.

(Staples, 2017)

We need to recognise, create whenever possible, and grasp those moments, small and big, when they arise. 


\section{References}

Alexander, N. 2007. Affirmative action and the perpetuation of racial identities in postapartheid South Africa. Transformation, 63. https://doi.org/10.1353/trn.2007.0013

Alexander, N. 2013. Thoughts on the New South Africa. Auckland Park: Jacana.

Appiah, K.A. 2010. The Honor Code: How Moral Revolutions Happen. New York: W.W. Norton.

Bauman, Z. 2000. Modernity and the Holocaust. Ithaca, NY: Cornell University Press.

Dubow, S. 1995. Scientific Racism in Modern South Africa. Cambridge: Cambridge University Press.

Fields, B.E. \& Fields, K.J. 2012. Racecraft: The Soul of Inequality in American Life. London: Verso.

Fioramonti, L. 2013. Gross Domestic Problem: The Politics Behind the World's Most Powerful Number. London: Zed.

Gilroy, P. 2010. Darker Than Blue: On the Moral Economies of Black Atlantic Culture. Cambridge, MA: Belknap Harvard.

Haslam, D. 2016. Musique de France. London Review of Books. https://bit.ly/2QZt2Bv

Kahneman, D. 2012. Thinking, Fast and Slow. London: Penguin.

Malik, K. 1996. The Meaning of Race: Race, History and Culture in Western Society. Basingstoke: Macmillan. https://doi. org/10.1007/978-1-349-24770-7

Malik, K. 2014. The Quest for a Moral Compass: A Global History of Ethics. London: Atlantic Books.

Malik, K. 2017. How did the left radicalism of my Manchester youth give way to Islamism? The Guardian [Online]. https://bit. ly/2QWhnUb

Malik, Z. 2012. The Asian Youth Movements. BBC Radio 4 [Online]. https://bbc.in/ $2 \mathrm{u} 6 \mathrm{tg} 0 \mathrm{E}$

Maré, G. 2014. Declassified: Moving Beyond the Dead End of Race in South Africa. Auckland Park: Jacana.
Maré, G. 2017. Inequality and race: Pointers to an approach. In: G. Antonelli \& B. Rehbein (eds.). Inequality in Economics and Sociology. London: Routledge. https://doi. org/10.4324/9781315558936-11

Maré, G. 2018. Templates of ordering and maintaining the social: Racial identities and consequences. In: N.G. Jablonski \& G. Maré (eds.). The Effects of Race. Stellenbosch: African Sun Media.

McQueen, I. 2015. How the failed ideals of 1970 s activists haunt post-apartheid South Africa. The Conversation [Online]. https:// bit.ly/2tenlXB

Nuttall, S. 2009. Entanglement: Literary and Cultural Reflections on Post-Apartheid. Johannesburg: Wits University Press. https://doi.org/10.18772/12009084761

Solnit, R. 2006. A Field-Guide to Getting Lost. New York: Penguin.

Staples, B. 2017. What if the court in the Loving Case had declared race a false idea? The New York Times [Online]. https://nyti. $\mathrm{ms} / 3$ aiwOxo

Therborn, G. 1999. The Ideology of Power and Power of Ideology. London: Verso.

Therborn, G. 2013. The Killing Fields of Inequality. Cambridge: Polity.

Turner, R. 1972/2007. The Eye of the Needle. Johannesburg: SPROCAS 2/London: Seagull Books.

Walters, H. 2019. Race classification and the spectre that haunts. In: G. Maré (ed.). Race in Education. Stellenbosch: African Sun Media. 

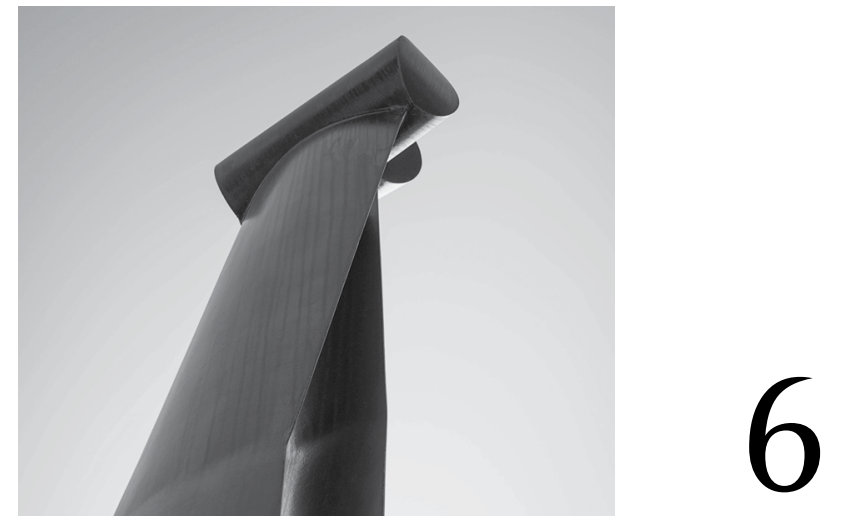

\title{
THE EFFECTS OF RACISM ON THE HUMAN BODY
}

\author{
Nina G. Jablonski
}

\section{Introduction}

The Effects of Race Project sprang from the observations and realisations of many people who voiced their concern over the diverse and sinister effects of race labelling, racialism, racism, and "race-thinking" in general. Foremost amongst the descriptive phrases that arose repeatedly in early discussions, was the "everydayness of race". For people in South Africa, the United States, and many other countries, the construct of race is an established part of social reality. Race is considered normal and a natural part of the social order. In these racialised realities, constructs of otherness underlie tacit and explicit expectations of character, intelligence, motivation, and behaviour. The concept of racialism - the formal acceptance and recognition of the reality of race and races - created a frame of acceptability for a range of behaviours from the personal to the political. Racism itself followed like a shadow, because the distance between people created by the establishment of otherness made it easier to unleash suspicion, derogation, and dehumanisation. 
In this chapter, I am not seeking to explore the psychosocial and societal problems caused by race, racism, and racialism because these have been and are being addressed much more authoritatively and sagely by others. Rather, I seek to draw attention to the wide-ranging biological effects of race-thinking and racism on the human organism.

\section{The hidden scourge of race-thinking and racism}

Race-thinking and racism are associated with so many dehumanising negatives that it is hard point to one that is the point to one aspect that is the worst or most heinous. It is thus worth considering one of the less obvious - the effects on health. If I were asked what I would most like to change with regard to race and racism, it is the constellation of divers, serious, sinister, and often life-long biological, health and psychological consequences of acute and chronic stress on the human beings who are subjected to racial othering and overt racial discrimination. There are many kinds of acute and chronic stressors, and these affect individual physical and psychosocial health through many routes affecting, broadly, the circumstances of life. Many such stressors are subtle and may seem minor at the time, but their private and, often, hidden nature makes them all the more sinister and dangerous. These hidden insults are realised in adverse effects on the body and health that may be "silent" initially, but that exert their negative effects after a lifetime of accumulation. Some of these effects have the potential to span generations. Therborn (2018) has written that racism is best considered as an "existential inequality" that "affects us as persons by shaping our constitution and recognition as autonomous and integral subjects". In other words, racism diminishes or denies agency and personhood. But we must see racism now as much more than this. It is also a "vital inequality", a social construction that shapes human life courses "with respect to life expectancy, health, and mental-somatic development" (Therborn, 2018).

Racism is an institutionalised system of oppression that designates value to persons based on race or ethnicity. Racism and racial discrimination directly affect health and well-being through health disparities at multiple levels. They also indirectly affect health by affecting socioeconomic position. Institutional racism is characterised by large organisations and imposes practices that negatively affect access to health services. Personally mediated racism occurs when healthcare providers maintain preconceived notions about racial groups which then result in the provision of substandard healthcare to racial minorities. Lastly, internalised racism involves the embodiment and acceptance of stigmatising messages by individuals in racially oppressed groups from society (Prather, Fuller, Marshall \& Jeffries, 2016). Internalised racism may be the most pernicious and least well understood, but recent research is providing insights into how chronic stress and 
negativity affect individual health through multiple pathways, including epigenetic modification of genes that control key physiological reactions.

\section{The lasting effects of stress caused by racism}

Racism has diverse and long-lasting effects on people and, far from being transient and "merely" psychological, it can cause irreversible and permanent changes to the body. The toll on personal health and well-being taken by racism, "from crib to coffin", has been recognised for decades (Gee, Walsemann \& Brondolo, 2012). Epidemiological studies have documented that the psychological stress attendant with racism has a significant deleterious effect on the development and progression of atherosclerosis, a precursor to serious cardiovascular disease (Saban, Mathews, DeVon \& Janusek, 2014). An individual's social context, especially during childhood and adolescence, is a powerful predictor of adult health, suggesting that the origins of health disparity are rooted in one's early social environment and life experiences (Saban et al., 2014). What research in the last two decades has revealed, is that social context influences the human organism at many levels, including the genetic. The physical and social environments in which a person develops and lives, trigger a series of biological responses that act on an individual's genetic blueprint (their DNA) to adjust development and lifelong programmes of bodily and mental function. In other words, human bodies and human genes are being constantly remodelled by the physical and social environment and by life experience. Far from being a passive carriage for behaviour, the body is profoundly affected by behaviours and the greater environment. The genetic programme for the body's structure and function is subject to modification by life experience and an individual's environment in the broadest sense. Of critical importance to this discussion is that the ways in which the environment may differentially integrate with genomic information are extremely varied, and that the outcomes of these interactions cannot be predetermined.

There has been much discussion in the last decade about epigenetics and its effects on human development and health. Epigenetics is the study of changes in organisms caused by modification of gene expression rather than alteration of the genetic code itself. Epigenetic changes are chemical modifications to the genome that do not alter the DNA sequence, but influence expression of the encoded genes. Epigenesis, thus, is the transmission of information to new cells during cell division that determines how genes are expressed: which genes present are "turned on" and which are silenced (Combs-Orme, 2013). Epigenetic modifications may play a profound role in translating changes in the social and behavioural environment into changes in gene expression and thence to behaviour, via a long and winding, and not predetermined, road. The field of social and behavioural epigenetics is 
focused on studying the effects of psychosocial stressors on the human phenotype (Mulligan, 2016). Many excellent reviews on social and behavioural epigenetics are available, including those written for specialists (Cunliffe, 2016; Denhardt, 2018; Notterman \& Mitchell, 2015; Vick \& Burris, 2017) and non-specialists (CombsOrme, 2013; McEwen \& Getz, 2013; Oyama \& Terry, 2016) alike.

One of the most disturbing set of discoveries emanating from research on epigenesis is that the stresses realised by an individual can affect not only the way the genes of a person work, but that some of these stress-related modifications are heritable (Szyf, Tang, Hill \& Musci, 2016; Vandegehuchte \& Janssen, 2014). When genes that control the expression of brain proteins or that modify the function of the immune system are affected by environmental (including psychosocial) stressors, the effects can be extremely serious. Epigenetic studies have the potential to elucidate the specific biological mechanisms by which social conditions become physically embodied (Needham et al., 2015). The negative biological effects of racism can be compounded over time because of the feedback loops generated by social and behaviour stressors, which induce negative emotions and accompanying biochemical and physiological changes. Behavioural functions are particularly sensitive to the programming effects of stress and nutrition during early life.

How exactly does racism affect the human body and why should it be considered an expression of vital inequality? When members of stigmatised racial populations respond to the pervasive negative racial stereotypes by accepting as true the dominant society's beliefs about their biological and/or cultural inferiority, they can internalise the racism or self-stereotyping. Internalised racism fosters the endorsement of beliefs about the innate deficiencies of one's self and one's group, and leads to lower self-esteem and psychological well-being, which in turn could adversely affect health and health behaviour in multiple ways (Williams \& Mohammed, 2013a, 2013b). Internalised racism is associated with alcohol consumption, psychological distress, being overweight, abdominal obesity, blood pressure, and fasting glucose (ibid.). Perhaps even more worrying, however, is the evidence that links social environmental conditions with changes in gene regulation, a relationship that parallels and extends the effects of the social environment on other physiological traits (Tung \& Gilad, 2013). Social status and social isolation are associated with changes in gene expression for a large number of genes. It comes as no surprise too that, because of racism, residential segregation, and structural inequality in our society, women and children suffer disproportionately from exposure to poor physical and social environments (Shields, 2017).

The most common epigenetic mechanism associated with environmental and social stress involves the methylation of DNA. DNA methylation is typically associated with gene suppression, as methyl groups that become added to DNA can 
interfere with the process of gene transcription. Alterations in DNA methylation serve as means by which risk and protective factors may affect an organism's appearance and its activity (its phenotype). DNA methylation is also increasingly being recognised as a biological process that can influence our psychological functioning from infancy to senescence (Roth, 2013). Low socioeconomic status (SES) is associated with DNA methylation several genes related to stress reactivity and inflammation. To the extent that patterns of DNA methylation influence gene expression, these findings could help explain why low SES is associated with excess morbidity and mortality (Needham et al., 2015). Although we are far from a complete understanding of the cause-and-effect role of epigenetic mechanisms in health and disease, evidence is clear that epigenetic alterations are biological consequences of environmental input throughout the life course, with early life effects being the most critical.

Epigenetic information is itself susceptible to change: its impact can be manifest as long as the environmental factor is present or can persist in its absence (Saban et al., 2014). This is extremely important as we consider the reversibility and possible transgenerational impacts of epigenetic effects. Epigenetic marks may be transmitted across generations, either directly by persisting through cell division leading to the production of eggs and sperm, or indirectly through replication in the next generation of the conditions in which the epigenetic change occurred (Rubin, 2016). New evidence indicates, however, that DNA methylation may not result in indelible epigenetic marks and that different signals arriving at intervals over a lifetime act on the genome and epigenome of the time to affect the next phase of life (Patchev, Rodrigues, Sousa, Spengler \& Almeida, 2014). Amongst the many things we don't yet know is how consistent exposure to positive, supportive environments produce a methylation pattern that places children on a positive developmental trajectory, and more resilient to subsequent adversities (Szyf et al., 2016). We are also ignorant of the mechanisms whereby DNA methylation patterns defined by early life experience are altered with childhood, adolescence, and adult experience, and how these changes relate to environmental exposures (ibid.). This information will help determine the best times for intervention, and the narrowness of the window for prevention.

\section{Epigenetic information does not mean "no hope"}

The knowledge that epigenetic research brings to light is both worrisome and elevating with respect to the long-term mitigation of the effects of racism on human well-being. It leads us, first of all, to the realisation that it is incumbent upon all governments to recognise the seriousness of the effects on human well-being of epigenetic influences, especially in early life. Findings from epigenetic studies 
should be used to promote widespread social reforms that fight the larger geographic, sociocultural, economic, and political contexts in which health disparities are embedded (Oyama \& Terry, 2016). The development of a healthy citizenry capable of making rational decisions depends upon people growing up with adequate nutrition, protected from violence and gross insecurity, and raised in environments conducive to the development of emotional security. The negative influences of racism on human health are, in many respects, similar to the negative effects of extreme poverty. With much of the world now living in highly urbanised environments in which traditional modes of nurturing individuals and policing behaviour have been eliminated, governments have a solemn responsibility to insure adequate nutrition, physical and psychosocial health care, and reduction of the threat of violence, especially against the most vulnerable members of society (children, the elderly, and women). The role of "big government" in recognising these problems and preventing their further manifestation is self-evident and must be seen as the central role of the modern state.

It has been recognised for a long time that poverty, poor nutrition, child abuse, trauma, and other adverse exposures were bad for health. What epigenetic research offers is the shedding of light on the biological pathways through which such exposures are translated into concrete, measurable increased risks of various diseases. The linkages amongst social context and epigenetics that influence the risk of cardiovascular disease, for example, have potential to support health policies aimed at the social roots of disparity in this and other disease processes. Recognition of aspects of the family and community that increase the risk of epigenetic modification may reveal aspects of the early environment that can be modified as part of community level efforts to improve well-being in those at risk (Saban et al., 2014). To the extent too that epigenetics offers a view to understand the pathways through which a mother's social disadvantage could be translated to her child's vulnerability to disease, knowledge of epigenetic mechanisms may galvanise support for public health interventions and generate new ideas for effective interventions (Shields, 2017).

The elimination of many of the health problems caused by racism does not necessarily require the eradication of racism itself, as desirable as this is, nor does it require enormous amounts of money. In this regard, Cuba stands as an example of a society in which the risk of adverse epigenetic modifications to humans has been reduced through vigilant preventive health care, conscientious antenatal care and monitoring of childhood nutrition, and reduction of the effects of acute and chronic stressors through a medical system focused on intensive personalised care provided by networks of local care givers. In Cuba, the government is also highly vigilant of any resurgence of racism because of its many recognised and ramifying adverse 
effects. Epigenetic research suggests that health promotion beginning from the prenatal period and taking an intergenerational perspective, as the Cuban system does, creates a highly propitious environment for human thriving. It also provides a useful tool for refocusing policy makers' attention back to the communities in which people live and work, and the daily quality of their lives that shape their health and those of their offspring (Shields, 2017). This novel and comprehensive approach may be the best way to help prevent health disparities from occurring and may be one of the most effective ways of reducing the multifarious negative effects of racism.

As knowledge of epigenetic processes grows, so should the capacity to develop earlylife interventions to prevent or mitigate child health disparities. Understanding how genes are differentially regulated by experience will affect how we conceptualise social inequalities and health disparities. Rather than engaging in nature versus nurture debates concerning race as a genetic or social construct, considering race as an epigenomic construct (Rubin, 2016) maybe the most accurate and appropriate perspective yet. The view in which genotype and the socially experienced world are perpetually entwined (Rubin, 2016) is the real world in which people live. 


\section{References}

Brown, W. 2018. "What Kind of World Do You Want to Live In?" Political Science Commencement, UC Berkeley, 14 May. https://bit.ly/3aPyFdI [Accessed 27 January 2020].

Combs-Orme, T. 2013. Epigenetics and the social work imperative. Social Work, 58(1). https://doi.org/10.1093/sw/sws052

Cunliffe, V.T. 2016. The epigenetic impacts of social stress: How does social adversity become biologically embedded? Epigenomics, 8(12). https://doi. org/10.2217/epi-2016-0075

Denhardt, D.T. 2018. Effect of stress on human biology: Epigenetics, adaptation, inheritance, and social significance. Journal of Cellular Physiology, 233(3). https://doi. org/10.1002/jcp.25837

Gee, G.C.; Walsemann, K.M. \& Brondolo, E. 2012. A life course perspective on how racism may be related to health inequities. American Journal of Public Health, 102(5). https://doi.org/10.2105/ AJPH.2012.300666

McEwen, B.S. \& Getz, L. 2013. Lifetime experiences, the brain and personalized medicine: An integrative perspective. Metabolism, 62(Supplement 1). https://doi. org/10.1016/j.metabol.2012.08.020

Mulligan, C.J. 2016. Early environments, stress, and the epigenetics of human health. Annual Review of Anthropology, 45(1). https://doi.org/10.1146/annurevanthro-102215-095954

Needham, B.L.; Smith, J.A.; Zhao, W.; Wang, X.; Mukherjee, B.; Kardia, S.L.R.; Shively, C.A.; Seeman, T.E.; Liu, Y. \& Diez Roux, A.V. 2015. Life course socioeconomic status and DNA methylation in genes related to stress reactivity and inflammation: The multiethnic study of atherosclerosis. Epigenetics, 10(10). https://doi.org/10.1080/1559229 4.2015.1085139

Notterman, D.A. \& Mitchell, C. 2015. Epigenetics and understanding the impact of social determinants of health. Pediatric
Clinics of North America, 62(5). https://doi. org/10.1016/j.pcl.2015.05.012

Oyama, S. \& Terry, S.F. 2016. Epigenetics and racial health inequities. Genetic Testing and Molecular Biomarkers, 20(9). https://doi. org/10.1089/gtmb.2016.29021.sjt

Patchev, A.V.; Rodrigues, A.J.; Sousa, N.; Spengler, D. \& Almeida, O.F.X. 2014. The future is now: Early life events preset adult behaviour. Acta Physiologica, 210(1). https://doi.org/10.1111/apha.12140

Prather, C.; Fuller, T.R.; Marshall, K.J. \& Jeffries, W.L. 2016. The impact of racism on the sexual and reproductive health of African American women. Journal of Women's Health, 25(7). https://doi. org/10.1089/jwh.2015.5637

Roth, T.L. 2013. Epigenetic mechanisms in the development of behavior: Advances, challenges, and future promises of a new field. Development and Psychopathology, 25(4pt2). https://doi.org/10.1017/ S0954579413000618

Rubin, L.P. 2016. Maternal and pediatric health and disease: integrating biopsychosocial models and epigenetics. Pediatric Research, 79(1-2). https://doi.org/10.1038/ pr.2015.203

Saban, K.L.; Mathews, H.L.; DeVon, H.A. \& Janusek, L.W. 2014. Epigenetics and social context: Implications for disparity in cardiovascular disease. Aging \& Disease, 5(5). https://doi.org/10.14336/ AD.2014.0500346

Shields, A.E. 2017. Epigenetic signals of how social disadvantage "gets under the skin": Achallenge to the public health community. Epigenomics, 9(3). https://doi. org/10.2217/epi-2017-0013

Szyf, M.; Tang, Y-Y.; Hill, K.G. \& Musci, R. 2016. The dynamic epigenome and its implications for behavioral interventions: a role for epigenetics to inform disorder prevention and health promotion. Translational Behavioral Medicine, 6(1). https://doi.org/10.1007/s13142-016$0387-7$ 
Therborn, G. 2018. Racism, existential inequality and problems of categorical equalisation: Reflections on the South African experience. In: N.G. Jablonski \& G. Maré (eds.). The Effects of Race. Stellenbosch: African Sun Media.

Tung, J. \& Gilad, Y. 2013. Social environmental effects on gene regulation. Cellular and Molecular Life Sciences, 70(22). https://doi. org/10.1007/s00018-013-1357-6

Vandegehuchte, M.B. \& Janssen, C.R. 2014. Epigenetics in an ecotoxicological context. Mutation Research/Genetic Toxicology and Environmental Mutagenesis, 764-765. https://doi.org/10.1016/j. mrgentox.2013.08.008
Vick, A.D. \& Burris, H.H. 2017. Epigenetics and health disparities. Current Epidemiology Reports, 4(1). https://doi. org/10.1007/s40471-017-0096-x

Williams, D.R. \& Mohammed, S.A. 2013a. Racism and health I: Pathways and scientific evidence. American Behavioral Scientist, 57(8). https://doi. org/10.1177/0002764213487340

Williams, D.R. \& Mohammed, S.A. 2013b. Racism and health II: A needed research agenda for effective interventions. American Behavioral Scientist, 57(8). https://doi. org/10.1177/0002764213487341 

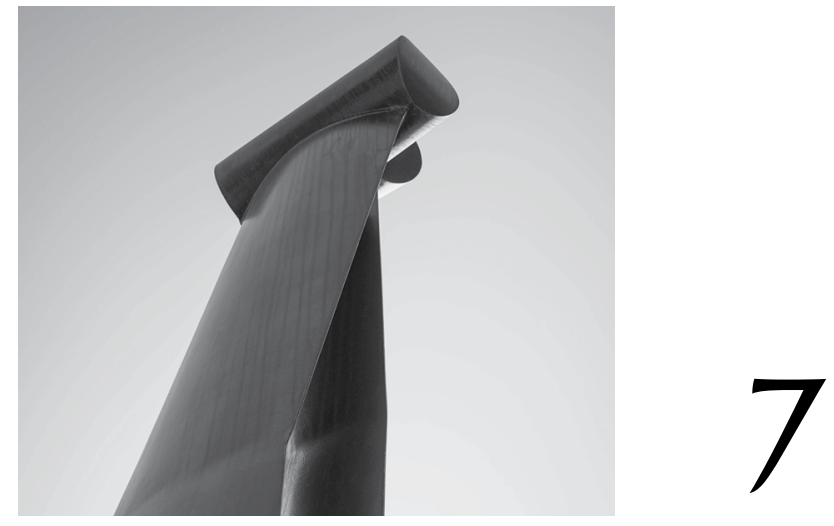

\title{
KNOWING AND BEING
}

Living our learning about "race"

\author{
Crain Soudien
}

\section{Introduction}

This short reflection works with the question of knowing and the implications of knowing for how we live our lives. Its particular concern is with the ways in which we come to know about "race" and the implications of this for how we manage living with what we think of as racial difference.

A stimulus for the reflection comes, at one level, from the timeless problematique of bystanding seen, of course, most poignantly, in the post-apocalyptic, and as yet-incompletely explained puzzle of our behaviour as educated human beings in the holocaust of World War II. We were complicit in different ways, astonishingly at a stage of our civilisational trajectory when we were supposedly at an advanced stage of human development, in that intense moment of modern barbarism in the deliberate killing of more than six million human beings. They were Jews, people we called Gypsies, communists, gays - people whom we deemed to be other. 
We looked on as they were systematically murdered. We knew, but, it seems, we also did not know. ${ }^{1}$

The more specific stimulus, at another level, is about knowing, knowing as deep comprehension - comprehending a matter conceptually and analytically in order to be able to deconstruct it and present it in its constituent causative elements. It is distinguished from the kind of knowing seen in bystanding, raised classically by Latané and Darley (1970) in their study of people's reactions to alarming incidents. That knowing is essentially noticing, of being a witness to an event. Knowing as it is approached here builds on the work of Miranda Fricker (2007) and the approach she uses of "thinking in moral colour", of the ability to explain a phenomenon beyond its surface features so as to understand it in its historical and contextual distinctiveness.

In this reflection, using Fricker, I consider the implications of knowing about "race" in the deep sense. Where Fricker concentrates on how bad knowing works - what she calls epistemic injustice and the effects it has on subjected people, that is, the "wrong done to someone" based on our personal beliefs about them or on what our environment has taught us - I am more interested in the ethical implications that arise for the knower (Fricker, 2007:1) who knows more than superficially. I am interested in that stage of our cognitive development where we can see and understand the workings of prejudice but cede our moral decision-making to the baseline of the normative order in which we find ourselves. How is it, I ask, that we are able to claim for ourselves that special feat of self-consciousness of being able to explain how prejudice operates in and around us, but, and this is our contemporary puzzle, as knowers, function according to the normative order around us (see Fricker, 2007:38).

Knowing, I argue, raises two issues. The first is about consciousness and its obligations. The second, flowing from the first, is about consciousness in situ what might be described as the politics of positionality, how one is placed and how one comes to deal with the existential paradoxes and contradictions which flow

1 The work of Cohen on bystanding is valuable here. He identifies three kinds of bystanding: the first where there is acknowledgement of something that may have happened but a genuine ignorance, for whatever reason, of the facts; the second where there is deliberate and intentional denial that is clearly meant to deceive; and a third where a 'switching-off' or a 'blocking-out' takes place (see Cohen, 2001:4). It is the third that holds most significance for this discussion here. It is about "knowing" and yet not "knowing." As Cohen (2001:5) says, there seem to be 'states of mind, or even whole cultures, in which we know and don't know at the same time.' The implicit and unarticulated cultural compacts within this kind of knowing in which experiences of oppression, discrimination and exclusion can be 'known' but disavowed or not fully acknowledged are important to understand. 
from the ways in which dominant thinking positions one. The chapter concentrates on the first. It uses this first reflection to find a way into the second challenge of managing one's positionality.

The first is that of how we make the science around "race" socially consequential. How do we take what we know scientifically about "race", as opposed to our popular conceptions - our "street talk", our handed-down understandings, our observations of "reality", our intergenerational conceptions, our "common sense", our politically-generated explanations, our social beliefs and desires and aesthetics, our social justifications for why it must be preserved, our prejudices and half-truths about "race" - into everyday behaviour, on the one hand, and public policy, on the other? The question I work with is that of whether the real doubt and caution that most of the world's leading scientists are bringing to the discussion about "race" that it does not exist in objective terms - has any significance for us? The syllogistic counterpoints I work with, as I pose the question, are Copernicus' discovery of the orbital relationship of the Sun and our planet Earth and the evidence we have for evolution. I concede that there are people who reject what science and reason tell us, who took, and in some cases still take, position against Copernicus and, more pertinently in the contemporary moment, who are now actively defending a creationist view of the world against what we know about evolution in relatively objective terms. In line with this, I accept that there are people who choose to reject what we know scientifically about "race". These people, I argue, are not knowers of "race". They may know other things relating to "race", such as the ostensive experience of racism - its pains and traumas - and may have important things to say about how racism works and its effects, but, for whatever reason, they do not know the concept of "race". They are not the people I am concerned about. The reflection is focused on those who accept the science around "race" and who generally begin their engagements with the enunciation that "race" is a social construction.

I pose the question here of what they - we - do with that science. With that clarification, the purpose of this reflection is to pause for a moment over the ontological implications of knowing in a deep way. I ask the question of what the personal and social implications are of understanding the racial question. Does it demand anything of us at all? Does it, to be provocative, have any call on our moral decisions in terms of our sense of responsibility to each other? Does it require of us, as we stand before each other as strangers or even as people who claim to know each other, to be managing ourselves in any particular kind of way? What does the fact of the physical presence of another human being in my consciousness, apart from being able to acknowledge his or her ineffability, require of me? 


\section{So what do we know about "race"?}

In terms of the science around "race", most, not all, scientists are now of the view that "race" cannot be "proved" biologically. Leaders of two major scientific groups have expressed themselves on the question of whether "race" exists or not. In 1997, the American Anthropological Association gathered to consider the question and in 1998 issued the AAA Statement on 'race', "[w] ith the vast expansion of scientific knowledge in this century ... it has become clear that human populations are not unambiguous, clearly demarcated biologically distinct groups. Evidence from the analysis of genetics (for example, DNA) indicates that most physical variation, about $94 \%$ lies within so-called racial groups ... There is greater variation within 'racial' groups than between them ..." (American Anthropological Association, 1998). The second panel, made up of a group of Stanford University scientists, issued an open letter in the journal Genome Biology on "the ethics of characterizing difference: guiding principles on using racial categories in human genetics" (Lee et al., 2008). The questions underpinning their approach included the following: "Can we find areas of common ground? Do we agree about the implications and the interpretation of emerging genetic data? Under what conditions might genetic data transform social understandings of racial and ethnic categories, possibly enhancing racist ideologies?" (Lee et al., 2008:par. 2). Pertinent amongst their ten statements were principles for the use of racial and ethnic categories in looking at group differences. The first statement was: " $[\mathrm{w}] \mathrm{e}$ believe that there is no scientific basis for any claim that the pattern of human genetic variation supports hierarchically organized categories of race and ethnicity" (Lee et al., 2008:par. 3). Their second statement elaborated this position: "We recognize that individuals of two different geographically defined human populations are more likely to differ at any given site in the genome than are two individuals of the same geographically defined population" (Lee et al., 2008:par. 5). A seventh statement went as follows: "We discourage the use of race as a proxy for biological similarity and support efforts to minimize the use of the categories of race in clinical medicine, maintaining focus on the individual rather than the group" (Lee et al., 2008:par. 16). ${ }^{2}$

2 Interestingly, in an attempt to disseminate this open letter more widely, Devin Powell (2008:par. 4), writing in the New Scientist, demonstrates the captured nature of the discourse around difference and its taxonomies. He presents this capture in his styling of the letter as "The Ten Commandments of Race and Genetics". He fails to assimilate the fact that the authors of the Open Letter deliberately and consciously refrain from using the term "race". They refer, instead, to the term 'population groups'. Powell, in paraphrasing the statement, makes the first statement of the scientists exactly the opposite of what they had sought to problematise, writing it as "All races are created equal" (Powell, 2008). 
Not all geneticists, predictably, go along with this. Most notably, Richard Dawkins and Yan Wong have argued that "however small the racial partition of the total (genetic) variation may be, if such racial characteristics as there are highly correlate with other racial characteristics, they are by definition informative, and therefore, of taxonomic significance" (Dawkins \& Wong, 2005:406-407). Recently the geneticist Richard Reich contributed to the debate in a profoundly provocative way. In a reflection on the significance of new understandings in genetics for thinking about "race", he suggested that the "consensus" that "race" was a social construct was being made into an "orthodoxy":

[...] over the years this consensus has morphed, seemingly without questioning, into an orthodoxy. The orthodoxy maintains that the average genetic differences among people grouped according to today's racial terms are so trivial when it comes to any meaningful biological traits that those differences can be ignored.

The orthodoxy goes further, holding that we should be anxious about any research into genetic differences among populations ...

I have deep sympathy for the concern that genetic discoveries could be misused to justify racism. But as a geneticist I also know that it is simply no longer possible to ignore average genetic differences among 'races'.

(Reich, 2018:par. 3-6)

It is this that brings us to the position which says that we now have almost unanimous agreement about what "race" means - almost because doubters such as Dawkins and Reich are important to pay attention to. Doubters notwithstanding, it is reasonably correct to say that we have come to a point where the evidence is largely that we as a human population, all around the world, have common origins. The study of genomics has shown us that our genetic history can be traced back to a single group of Homo sapiens which originated in Africa more than 200000 years ago and began to disperse around 60000 years ago to the rest of the world.

The interesting issue which comes out of our inability to say categorically that "race" does NOT exist, as Dawkins suggests, is that there are groups of people amongst us who have with respect to particular characteristics similar genetic profiles, beyond the problematic $0,1 \%$ visible differences which have been used in eugenicist explanations of race. These people can be identified by the recurrence or frequency of distinct genetic markers, such as disease susceptibilities. These realities exist. It is important that they are discussed and worked with between biological scientists and social scientists because they involve social and political assessments which are unavoidable. They involve, and this is a key point in this argument, categorisation and classification. This as a methodological and processual reality is about sensemaking. We are not going to stop trying to make sense of complex things. We need, in this sense-making process, to classify and order. 
But, and here is the essential quarrel with people such as Dawkins and Reich, how do we classify and name those distinctive groups of people? "Races", "communities", "tribes" - all the synonyms we have for biologically/what-onelooks-like definitions of difference - or terms which reflect the specificity of their gene markers? Or do they even need to be marked out at all socially? We need to find ways of thinking about and defining categories and classifications which can be shown to be of value and use. So, in relation to this, is "race" the most appropriate way to account for, label and then ultimately classify differences such as those to which Dawkins refers? My own discomfort is that "race" as a category for working with, describing and making sense of these "natural" realities, as Dawkins suggests, is deeply problematic. It fails to acknowledge the ascriptive processes which accompany the idea of "race" and the ways in which the eugenics movement, past and current, uses biology and all its surrogate characteristics to allocate worth and value. Its presumptive first move is that the idea of "race" can be rendered in neutral ways. In this argument, it is not their neutrality that is at issue. At issue, is how they name and describe the groups of people with which they are working. Why does Reich speak of the west-African groups of people who present - to use a medical term - with distinct genetic characteristics as a racial group? Why does he feel the need to "race" them? I prefer, as the Stanford scholars do, the term "population groups". It is here that Reich falls short. He is able to show differences in the average incidence of particular disease profiles (even in the differences in height between "northern Europeans" and "southern Europeans" but which, interestingly, he does NOT racialise). He calls, however, these groups of people "races". Why he prefers this naming and attribution he, very interestingly, does not talk about. In what follows below, I try to make an argument for my position.

\section{Classification: The power of normative orders versus the consequences of knowing}

If "knowing" has moral consequences, is our knowing that "race" does not exist enough? What action does this "knowing" demand? I pose these questions in an attempt to situate what I would like to argue is a real challenge for science and how it is mediated and taught beyond the confines of the classroom.

The action called for, as is intimated in the discussion above with respect to Dawkins' apparent neutral use of the idea of "race", is being aware of the politics surrounding the knowing of "race." Central in that politics of racial knowledge is what we can call norming. It is important to understand norming and the normative order and how they work. 
What is a normative order? A normative order is the system of rules and shared expectations which a social system, and it can be big or small, uses to govern and manage itself. It is the rules and expectations that people have of each other when they are in each other's company - how individuals will treat each other, men will treat women, older people will treat younger people, people who are physically well will treat those they understand to be unwell, how rich people will behave towards poor people, how people who perceive themselves to be of different racial, cultural, national, linguistic backgrounds will relate to others who are supposedly different from themselves, the responsibilities that individuals and groups feel that they have towards each other. A norm becomes an order - order in the sense of how one does things - when it is both institutionalised as a rule and as a habit. You habitually, for example, relate to a person who you perceive as a woman in particular kinds of ways.

Why is the idea of a normative order important? It helps us distinguish right from wrong. It helps us to do what would be considered the right thing in a particular social environment. It is a socially stabilising device. Problematic as normative orders can be, we cannot do without them. Without them we descend into worlds of absolute arbitrariness. In that arbitrariness, we could justify through the invocation of all forms of unacceptable kinds of power any kind of behaviour. We would do things based on any kind of explanation. All that would matter in contexts such as those is the assertion that $I$ know better than you. This is not acceptable on any terms. It is for this reason that we deliberate and engage with each other and amongst each other to decide what is minimally acceptable in how we behave with respect to both ourselves and to each other. In this way, we manage ourselves as human beings. We establish baselines which we hold on to and reproduce.

But what if a normative order is problematic? What if that normative order has so conditioned reality, conditioned consciousness, conditioned knowing to the point of Cohen's (2001:5) disavowal that it is foundationally socially perverse? If that is the case, and we are, as with the question of "race", now moving to the point where we can say that patriarchal societies are an example of such institutionalised perversity, then we are in some trouble. That trouble, I would like to suggest, lies in the ways in which we as people come to make choices in our lives. Those choices, to compress complex lines of argument, come through the construction of what we believe to be the idea of the Ideal Society. The Ideal Society, as Jonathan Wolff (2015:22-23) argues, "is (often) based on principles of justice which are abstracted from particular conditions. The principles form a model to which all societies ... should aspire". As he says: "Much work in political philosophy, from Plato to Rawls, has taken this form, and the philosopher is a kind of legislator for an ideal society, with the hope that actual societies can be brought to resemble the ideal" (ibid.). 
Critical about this ideal is the way in which it comes to ontologise citizenship, the way in which it comes to give substance to subjectivity. It moves on from the ideal society to constructions of what the ideal subject is. It puts on personhood a particular normative obligation. This is how, as a human being, you should be.

The idea of the Ideal, to recover the point above of the necessity for having normative orders, is not something we should shy away from. Given the connectedness of the world, it should not be abandoned. The prospect of living in a world of arbitrary decisions could be catastrophic. But the idea of the ideal needs constant rethinking, theoretically and practically. There are deep theoretical issues about the ways in which its conceptual moorings overlook problems comes to build practices based on these blind spots. Both the conceptual and the practical are crucial to hold in constant critical perspective.

With respect to the conceptual, Charles Mills draws our attention to the very fundaments of the ideals that have governed our lives. The point he makes is that the supposedly "all-encompassing egalitarianism" of modernity's famous revolutions are profoundly flawed:

If modernity is supposed to eliminate the hierarchies of the pre-modern Western world, the reality is that it only does so (to the extent that it does) for white males ... white women's inequality is not eliminated but put on a different foundation ... in the case of people of color, a new structure of ascriptive hierarchy is created. As Frederickson underlines, the very fact that equality is supposed to prevail universally sharpens the contrast with those who are deprived of that status.

(Mills, 2015:51)

Mills goes on to say that part of the problem of mainstream ethical and political philosophy is its failure to recognise and explore the social and ontological category of sub-personhood - those forms of subjectivity which refuse to accord to people full person status. Racialised societies, he says, are not slightly but radically different from the normative ideal. They are so far from the ideal that they are what he describes as "ill-ordered" societies. Something went wrong with them. They went wrong in the dramatic sense that they institutionalised a scientific falsehood into everyday life. They took the scientific falsehood that human beings could be classified into distinct "races" and that these distinct "races" were fixed into a hierarchy of biological, cognitive and spiritual worth into their "knowing". This "knowing" was solidified and legitimised discursively - through the law and practice. In places such as South Africa, this "knowing", as was, indeed, the case in many parts of the world, was embroidered into the deep recesses of the physical and the mental. A falsehood was painfully stitched into the narrative ways through which human beings came to see and think of themselves. 
As Mills says, what do you do, how do you think about and how do you deal with societies which claim a particular normative philosophy but are so remote from what actually is happening inside of them? (Mills, 2015:58). Examples of such societies are societies such as the United States, South Africa and Brazil where the law represents the ideal of how inclusion should be defined and managed, but where everyday experience is what is actually determinative. Racelessness is the ideal. Whiteness and racism is the practice. In places such as these, there is a putative normative order and an actual one. The actual is what governs the society. How do we create "well-ordered" societies which will recognise their deviance from that which they rhetorically hold aloft? His response to these questions is that you need more than ideal principles. You need to institute into this normative approach principles of corrective justice. You need to think about, he suggests, "whiteness" and about its reconstruction. He says, and this is crucial for us here in South Africa, and particularly if we don't want to give up the possibility of formulating an ideal for ourselves, you need to think of what transitional principles you would need to be putting in place. Consequently, he makes an argument for the correctness of some form of corrective action as a principle - compensatory justice. How this compensatory justice is actually given substance to is a matter for debate. It requires coming to an empirical understanding of the actual causal mechanisms that are at work in creating the injustice in the first place and the development of processes to both undo the injustice and to replace it with alternatives which take one closer to the formal ideal.

Understanding the "causal mechanisms" in the making of normative orders is important. It is here that Daniel Putnam (2015) and Miranda Fricker (2015) are useful, and providing a way of putting Angier's comment about "what it is for people to relate to and treat one another as equals" (Angier, 2015:165), in its fuller perspective. The approach they take is broadly encapsulated in the term "methodological negativism". The focus of this shift around hermeneutic injustice is not material equality. They go beyond material equality. They want to get to Angier's question of what it takes for people to treat each other as equals.

What is, in our consideration of reconstituting the normative order, methodological negativism? Mills presents it as holding the keys to theoretical development to "guide us in the transition from our actual societies to" the ideal (Hull, 2015:3). There are many ways of doing methodological negativism. That which Putnam and Fricker focus on is the question of "knowing the other". Their advice is to move beyond sympathy and empathy. It is about coming to a better understanding of what went wrong in the ways people involved in unequal relationships came to the relationship come to an understanding of each other. Putnam's position is that dominant understandings of equality, especially those which describe equality as 
that relationship people from different and unequal positions enter into where they are joint deliberators and can give equal weight to those things which they deem to be important, do not sufficiently resolve the problem of what he describes as the understanding between people. The contribution Fricker makes is that of understanding what went wrong - or what Mills calls the non-ideal history the illicitly expanded rights and opportunities held by privileged people. What Fricker is asking is that we first should come to a sense of the causal factors in Mill's non-ideal history. She says, "if one is interested in justice, then it is helpful to look first at forms of injustice; if one is interested in equality ... look first at forms of inequality" (Fricker, 2015:73).

The inequality that Putnam and Fricker are interested in is that of what unequal people or individuals bring to their interrelationship. Fricker, working with Martha Nussbaum's list of capabilities, documents all the human functioning capabilities that are at issue in realising equality between people. As she says on that list of capacities is the capacity for "practical reasoning". Valuable as this is, she says, it does not accord any weight to what she calls "rational functioning in what is surely the most basic and truly human mode of theoretical reason: our functioning as contributors to shared information and understanding. One of our most basic needs is to use our reason in order to discern the everyday facts and social meanings that condition, constrain, and make sense of our shared lives. Indeed, many other functionings depend upon it" (Fricker, 2015:75). Raised here is not abstract reasoning, or simply the reasoning of the knower. It is the reasoning that has informed the relationship. This is essentially what Putnam was talking about when he was talking about intelligibility - understanding between people. Inequality will continue to be fundamental when this mutual intelligibility is absent. It is absent, as Fricker says, in big and small ways. Fricker's interest is in making better sense of the process through which one creates the conditions for marginalised people to make their interests intelligible. My own is in shifting the onus of responsibility in the ethical economy of the moment to the knower.

\section{The politics of positionality}

Critical here then, and this constitutes the second issue to which I drew attention above, is having a sense, in Fricker and Mill's terms, of "what went wrong". Understanding "what went wrong" is necessary for helping each of us come to a sense of our place and our positionality in society and the politics underpinning that positionality. But acutely pertinent and to the point here in coming to some clarity about our positionality is recognising who the "we" are in Mill's injunction that "we" should think. Who is he referring to when he asks that "we need to think?" 
The approach underpinning the argument worked with in this chapter is that hegemonic discourse, such as racism, in their totalising fantasies, and apartheid is an example (see Norval, 1996:109), seek to obtain our consent. The "who" in Mills' appeal, recognising how discourse seeks to work, is all of us. All of us are positioned by hegemony. All of us are, in these terms, required to think about the politics of our emplacement and what hegemony, in its tendentiousness, has in mind for us. We need to be mindful, as Wendy Brown (2018) remarked to students at a commencement ceremony at the University of California, Berkeley about "historical advantage" and how to work with it: "How can we burden you with this question, you who are just beginning your adult life. You who did not make this world filled with so many troubles and terrors?" Fairness, she argued, was not the issue:

If you stay with the question of fairness, you will stay with a child's view of what can be asked of you or what you can ask of yourself - the view from powerlessness and where the only expectation is that you play by common rules, set by others. The question of what kind of world you want to live in is an adult question; it has bearing when your life is in your own hands, when you have a little or a lot of power or latitude ...

The point is not to shift the question from one about yourself to one about the world - it is not to replace selfishness with selflessness or become creatures of bottomless sacrifice. Rather the point is to mix the questions of what you want to be and do with what you want this world to be, and let that mixture pave your way in the adult world.

(Brown, 2018)

Her point is that each of is, as emplaced subjects, have choices to make about how to proceed into the world. Her appeal was for the students to "frame" their thinking. In this, she was asking them to have a considered and deliberative perspective of the time and place in which they found themselves.

Significant about this address is its recognition, in response to the system's totalising hubris, of the need for all people to be thinking about their emplacement - both the powerful and the powerless and to take responsibility for a world "that you didn't build" (Brown, 2018). Central in this is looking forward to the kind of world, she says, "you want to live in" (ibid.).

The politics of Brown's argument, it may be argued, is its focus on a future, a world to come. It leaves, it could be suggested, the question of how one thinks of the past. It is here that we are required to locate our positionality and to look critically how each of us, as individuals and as members of groups, fit into the calculation of "unfair" and "unequal". The question is demanding. It requires a recognition of the big and provocative theories of intersectionality and the even more provocative analysis that none of us is ever outside of relationships of power. None of us is a pure victim or pure perpetrator. The politics of inequality, to put it bluntly, demands an 
awareness from each of us of how each of us has arrived at the places and positions we occupy in our present circumstances. This awareness requires an understanding of the many systems at work in our lives - the systems of racism, sexism, classism and all their multiple incarnations. It asks us, in the spirit of Wendy Brown, to acknowledge that each of us is implicated in the bearing of power in ways that are not of our own making. The point about this approach, and it is put here in an extremely condensed way, is that none of us is ever outside of these systems. They involve us in complex ways. None of us stands in a position of pristine innocence in relation to these systems. Almost every single one of has something to declare. We find ourselves, most of us, implicated in one way or another. The message Mills and Brown seek to bring holds for all of us.

But in each of these systems we are positioned in very particular kinds of ways. It is our awareness of these distinct kinds of positioning that matters. Racial systems, as Leathem and Bechus (2018) recently explained (they used the term "race"), allowed certain groups of human beings to derive privilege from their simple classification. Leathem, in a powerful address to his high school students at a Johannesburg school, explained that his parents grew up as white working-class people of Johannesburg, they were "dirt poor": "(My mother) was one of eight children; her father lost his leg fighting in the Second World War and the family had to get by on a meagre government disability pension". Despite this, they were able to work themselves out of poverty "because they were white" (Leathem \& Bechus, 2018:11). Now, it is true, of course, that there are people whose white classification has not been sufficient to rescue them from poverty - people like this exist. They might be disempowered in some ways but are empowered in others. But the majority have had what Leathem and Bechus (2018) call the privilege of their whiteness: "Their whiteness meant their hard work was allowed to amount to something". There is in this, of course, a kind of totting up of this disadvantage being greater than another. Racial disadvantage carries more weight than class disadvantage. What should people classified "white" do with this, ask Leathem and Bechus? Leathem suggests that the intention is not to have people "feel bad" about themselves, but for them to "Stop denying (their white privilege). Stop pretending it isn't real. Just acknowledge it. You have been given an unfair advantage" (Leathem \& Bechus, 2018).

What follows, argue Leathem and Bechus, and this is the conclusion to which I would come too, is that those of us who have been so positioned to advantage in terms of racism, and exactly the same applies to all forms of positioning by structures of dominance, have to do something meaningful with our knowledge - self-knowledge - of our advantage. How one uses it will, of course, in the mode of Brown above, depend on the kind of society which we wish to see coming into being, and in this, we will have a wide range of choices that we as individuals 
could make. These choices will themselves always be controversial. As long, as they can, however, be substantiated based on grounds that are wider and deeper than just our own, they provide us with the legitimacy to engage in a wider discussion about the public interest.

\section{Concluding thoughts: How would ethical thinking be brought about?}

What, following the discussion above, is the responsibility of the knower of "race"? This responsibility is multiple. It demands, in the first instance, the development in oneself of a hermeneutic of unconditionality in one's respect and regard for the other. The injunction is simple - the deliberate cultivation of a consciousness of regard for all human beings and the conscious commitment to understanding the other and his or her own coming to-consciousness strategies. ${ }^{3}$ The issue here is that of Fricker and Putnam's "mutual intelligibility", not the intelligibility practices of the knower alone. The knower, and this is the ethical task for the knower, has to be able to account for how he or she came to know the other. He or she must be able to deconstruct the cognitive pathway through which his or her comprehension of the other unfolded - what empirical or evidentiary sources were used, why were those chosen rather than others? Critically, on top of this, what were the criteria against which the evidence was collected? What founding principles of human difference were brought into play? The practice of this injunction is, of course, never without immense difficulty. It begins, however, with the fundamental presupposition of difference as that which needs to be understood rather than that which is to be presumed and it demands a critical engagement with the normative order and its classificatory instincts. Resisting these instincts is the difficulty.

How one takes this point of departure - what we know about "race" - into both popular discussion and into official policy-making is what, I would like to suggest, is at stake here - a caution and hesitancy in the invocation of these categories as opposed to their easy and natural use. This would have, I would argue, immediate knock-on effects in the ways we deal with racialisation and its follow-on processes of racism. This hesitancy and caution would have implications for both personal behaviour and policy formation. It may not change either, but it would require of everybody considerable more reflection of the consequences of the decisions they are making. Racialisation depends on the acceptance of the classification

3 Of course, as animal rights and other activists who are thinking of the wider planet would argue, and the new work of Achille Mbembe (2017) is crucial here, the Anthropocene in which we find ourselves has produced a profound disregard for other species and other forms of existence, including the physical landscape. It has privileged the human in deeply disrespectful ways (see also Latour, 2013). 
involved in the idea of "race". Racism depends on it too. If we can make everyone much more circumspect about what they understand, we may move towards more considered behaviour.

How we institutionalise this hesitancy is an immensely difficult task. Repeated explanation is necessary, but so is the deliberate insertion into the public and scientific imagination the counter-"factual", the repeated disruption of the normative regular - the use of wholesome, non-stereotypical and positively intriguing representations of those considered to be "other".

I focus here on the "explanation" part of trying to bring this change about. The difficulty can come to be understood by understanding, in turn, the way current and dominant ideas of "race" were introduced and embedded in people's consciousnesses. The "race" idea was an explanation for why people looked different to each other. But it simultaneously, and this is the difficulty, gave them in the context of the rapid economic development of the world in the nineteenth century, the moral, aesthetic, and affective arguments for their differences - their "superiority" (and, conversely, for the other, to make sense of their inferiority). It made it possible to produce and explain/justify regimes of oppression and exploitation from which particular people drew interest and received benefits.

One has here the emergence and development of a sensibility, a kind of zeitgeist. How do you change zeitgeists? How do you change something which becomes the spirit of the age? Here is the challenge. Because this zeitgeist is not just about reason, counter-reason alone or the provision of information about otherness, and its most naïve forms, as we see in dominant multicultural discourses are a good example, impacts very little on consciousness. The difficulty is how to extend knowing about the "stuff" of "race" from the realm of "pure reason" into the affective, the aesthetic and emotional parts of one's thinking. The question is how one comes to make another explanation about "race", an explanation which is cautious and questioning, one which gives people a sense that their interests are being served by it. How in a context in which the zeitgeist provides both material and psychological comfort does one make anti-racist thinking work in people's interest and from which they can see the derivation of benefit?

One is in this situation confronted here with the shortcomings of theories of change. A great deal of work is necessary here. But against this, the best that is currently possible, is to persist with a commitment to the provision of good education. Good education is when one's knowing has consequences, when people think about their knowing in moral terms. Good knowing could provide people the opportunity to be deliberate then about the full gamut of the social, political, and moral dimensions of what they know and to extend that into the implications of this good knowing for their personal choices. 


\section{References}

American Anthropological Association. 1998. AAA Statement on 'race'. https://bit.ly/2NxxvcN [Accessed 29 December 2019].

Angier, T. 2015. Hierarchy and social respect: Friends or enemies. In: G. Hull (ed.). The Equal Society: Essays in Theory and Practice. Lanham, MD: Lexington Books.

Butt, D. 2013. Option luck, gambling and fairness. Ethical Perspectives, 19(3).

Cohen, S. 2001. States of Denial: Knowing About Atrocities and Suffering. Cambridge: Polity Press.

Dawkins, R. \& Wong, Y. 2005. The Ancestor's Tale: Pilgrimage to the Dawn of Evolution. Boston, MA: Houghton Mifflin Harcourt.

Dworkin, R. 2000. Sovereign Virtue. Cambridge, MA: Harvard University Press.

Fricker, M. 2007. Epistemic Injustice. Power and the Ethics of Knowing. Oxford: Oxford University Press. https://doi.org/10.1093/ acprof:oso/9780198237907.001.0001

Fricker, M. 2015. Epistemic contribution as a central human capability. In: G. Hull (ed.). The Equal Society: Essays in Theory and Practice. Lanham, MD: Lexington Books.

Hull, G (ed.). 2015. The Equal Society: Essays in Theory and Practice. Lanham, MD: Lexington Books.

Latané, B. \& Darley, J. 1970. The Unresponsive Bystander: Why Doesn't He Help? New York: AppletonCenturyCrofts.

Latour, B. 2013. An Enquiry into Modes of Existence: An Anthropology of the Moderns. Cambridge, MA: Harvard University Press.

Leathem, K. \& Bechus, T. 2018. Want to help? Start by admitting you have had an unfair advantage. Business Day [Online]. https:// bit.ly/30rHup3
Lee, S.; Mountain, J.; Koenig, B.; Altman, R.; Brown, M.; Camarillo, A.; Cavalli-Sforza, L.; Cho, M.; Eberhardt, J.; Feldman, M.; Ford, R.; Greely, H.; King, R.; Markus, H.; Satz, D.; Snipp, M.; Steele, C. \& Underhill, P. 2008. The ethics of characterizing difference: Guiding principles on using racial categories in human genetics. Genome Biology, 9(7). https://doi.org/10.1186/gb-2008-9-7-404

Mbembe, A. 2017. Critique of Black Reason. Johannesburg: Wits University Press. https://doi.org/10.1215/9780822373230

Mills, C. 2015. Racial equality. In: G. Hull (ed.). The Equal Society: Essays in Theory and Practice. Lanham, MD: Lexington Books.

Norval, A. 1996. Deconstructing Apartheid Discourse. London: Verso.

Powell, D. 2008. 'Ten Commandments' of race and genetics issued. New Scientist Daily News [Online]. https://bit.ly/2FUz8Nd

Putnam, D. 2015. Equality of intelligibility. In: G. Hull (ed.). The Equal Society: Essays in Theory and Practice. Lanham, MD: Lexington Books.

Reich, D. 2018. How genetics is changing our understandings of "race". The New York Times [Online]. https://nyti. $\mathrm{ms} / 38 \mathrm{aMCQZ}$

Wolff, J. 2015. Social equality, relative property and marginalized groups. In: G. Hull (ed.). The Equal Society: Essays in Theory and Practice. Lanham, MD: Lexington Books. 

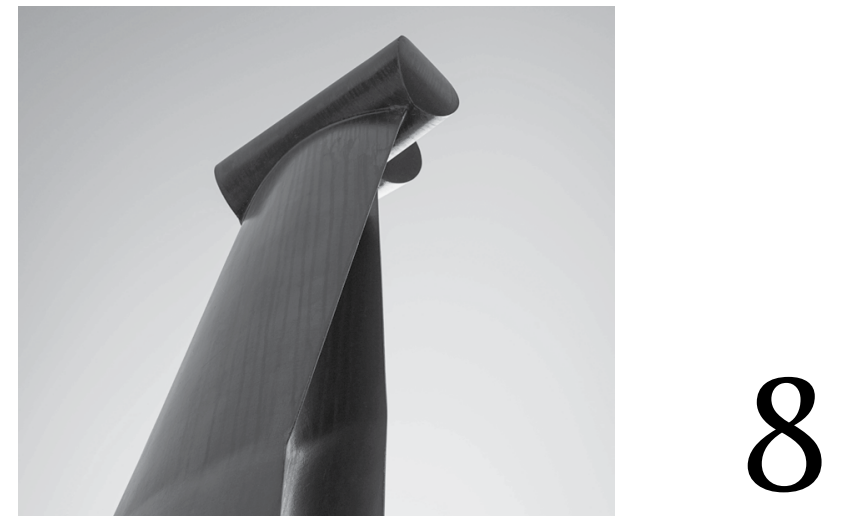

\title{
SEMANTICS IN THE PHILOSOPHY OF RACE
}

\author{
George Chaplin and Nina G. Jablonski
}

The three Questions: The problem of racial thinking

The three questions that framed the discussions of the Effects of Race Project in 2017 were, "What do you not like about race and racial thinking? "Why?" And "How would you fix it?" What we dislike most about race is its enduring and tenacious nature. This is despite the fact that it has been discredited by many scholars and constituencies and shown to be not useful. Race is an historical contingency, not a state of nature. Anthropologists see the commonality of humankind and a legacy of widely shared cultural and physical traits that outweigh any differences that may exist. The tenacity of race has made it possible for racism, its handmaiden, to grow and endure. Race has so co-opted our consciousness and language that it has made any attempt to deal with the effects of racism very difficult.

The addictiveness of racial thinking thwarts all attempts to unite humanity into a common cause. Philosophers are divided in their attitudes, with some preferring to split and others preferring to unite, but logically both attitudes can be defended. 
New attempts to erect race constantly arise based on economic, educational, biological, and most recently genetic grounds (El-Haj, 2007; Long, Li \& Healy, $2009 \mathrm{~b}$ ). This is despite the overwhelming commonalities of biology, culture (such as the universal love of music, dance, and ritual), social organisation, kinship structures, language, and spirituality which render minor differences and any subdivisions based on them meaningless (Relethford, 2009; Soudien, 2012).

What can be done about this enduring race ideology? We need to change the discourse by changing the lexicon. Language space is constantly changing, however, and semantic meanings reinforce past preconceptions and prejudices. This is because the innate structure of the brain and its pathways ensures that there is no negation in the subconscious. Reusing past pejoratives in new contexts will not remove their meanings, but only add to them. The name-space of race is so crowded that even neologisms with no past connections or meanings are hard to derive, but a new vocabulary is what is needed.

\section{Introduction}

The Western idea of real races, in a biological sense, was questioned at its start as being anti-biblical because it required there to have been separate creations (Sussman, 2014). Racialism and racism rose in the service of slavery and economic exploitation (Jablonski, 2012a; Samson, 2005). Generally, since the United Nations' (UN) Statement on Race (UNESCO, 1952) the acceptance of biological race has been in a very slow decline and had become almost universally moribund in scientific circles. Fairly recently, however, some philosophers, geneticists, and those in the medical professions have repeatedly tried to resurrect biological definitions of race (Bamshad, Wooding, Salisbury \& Stephens, 2004; Lee, Mountain \& Koenig, 2001; Wade, 2002). On the other hand, sociologists and the general public recognise that the idea of race, and its concomitant racism, is still a real phenomenon (Graves, 2015). If for no reason other than to recognise the reality of race in the social realm, we need to speak about it. The idea that racialism and racism will go away with non-discussion is nonsensical and wishful. Some favour the preservation of named races because they make it easier to preserve unity and a positive social identity amongst people who are or were oppressed. Those with an attachment to the idea of biological races see it as having some utility, perhaps as a shorthand for nested biological facts (Chaplin, 2018). Others seem to believe that if biological race is shown to be real, people will accept it and move on, or use supposed biological race to justify racial separatism as practiced by neo-Nazis.

Racial thinking is not just a metaphysical problem, it is a semantic one too. The language around race has been fully occupied and is nearly universally derogatory and hurtful. Neologisms like "people of colour" arose in the 1930s after "coloured 
people" became restricted to mean African American people in the United States, and again at the end of the twentieth century in an attempt to be inclusive of groups of people identified as non-European light skin. Basically, people of colour who designated the set included all non-white people who were subjected by the white dominant culture. Race is not always imposed on people, but is often willingly embraced. The economically powerful see race as a shorthand for class, intelligence and ability, and biology. The economically disadvantaged see it as a cause of their suffering and as a uniting principle. To both sides, it is a factor used to justify an Us-Them dichotomy. A similar phenomenon is observed in the use of regional dialects and accents in homogenous peoples where the upper class impose their perceived pronunciation on the lower classes and the lower classes cling to their accents. Therefore, the subjugated are not free from the support of racialised thinking, any more than Cockney speakers or people with Brooklyn accents are free from class discrimination. Thus, the Us-Them divide is often a two-way street, and the less advantaged of the two sides often don't help themselves by supporting the discriminatory status quo.

\section{Race labels and hate speech}

One effort has been to usurp hateful speech by the subjugated people themselves. A non-racial example would be "queer", a once very derogatory term for people who prefer partners of the same gender as themselves. Redeployment of the word as a positive identifier has been somewhat successful at lessening its broader impact as a slur. Within the queer community, the adoption of the "queer" has repurposed the term to be inclusive and accepting. The name is still used as marker of Us-Them, as in queer studies departments, and so still harkens back to the days of an Us-Them sexuality divide. In defeating homophobia, the neologism "gay" has been much more effective at heading-off discrimination. Within a few decades, "gay" has entered the lexicon of normative life. The acceptance of non-binary sexuality was greatly facilitated by the appropriation of a simple upbeat word. It has been remarkable that the once widespread public acceptance of homophobic speech within the United States is now seen as harmful and anachronistic (Watson, 2017), and is restricted to certain pseudo-religious political movements. In private, homophobic speech is still found within the more isolated, poorly educated, and economically depressed parts of society. It seems that today the acceptance of gay people is the norm and their rejection is the exception. This is a dramatic difference since the Stonewall riots of 1969, which can be seen as the start of the gay rights movement. Before then, non-homophobic people would routinely use the slurs popular with the bigoted. In places like San Francisco, even the label of "gay" is losing its power as the different sexual persuasions are now so normalised 
that there is no need to label people by their orientation. The mere absence of derogation, however, does not mean things are moving forward; it marks the beginning of that process.

There has been a similar attempt to appropriate racial hate-speech to lessen its power and unite its victims. In race speak, the hate-term, "nigger", which had previously only derogatory and disparaging connotations, has been co-opted by the very people it was applied to as their own neologism (Croom, 2011, 2013). It has been redefined in modern usage and sometimes modified slightly, for example, "nigga" of hip-hop and rap, as an empowering collective noun, usable only by the people to whom the term applies. This has created a lexicon of limited unity, centred on negativity, exclusivity, and division. The use of this term by those not in the inner circle of the term's reference - and probably not of the same race - is still seen as carrying its original meaning to those in the inner circle and by a large percentage of those outside too. Today, use of the word in its original context, with vehemence, is socially unacceptable and, for a public figure, career-ending. Use it in its neologistic sense, in the context of rap, requires mitigation by extensive apologies unless it is used by someone in the inner circle as an inclusive term about a shared experience. Peter Vecsay, a white sportscaster, was told not to use racial epithets applied to LeBron James when reporting a basketball game, even if he was only quoting a popular rap song (Watson, 2017). An even greater controversy arose over American late-night talk show host and comedian, Bill Maher, telling a racially charged joke using the "N-word". To quote rapper Ice Cube talking about the term as used by Bill Maher, "That word is like a knife", he said. "You can use it as a weapon or you can use it as a tool. It's been used as a weapon by white people, and we're not gonna let it happen again. That's our word now", Ice Cube continued. "And you can't have it back" (Thompson, 2017). To Ice Cube, it is a tool, but as he further pointed out, Bill Maher was not sounding funny, "Sometimes you sound like a redneck trucker". Here, Ice Cube seems to be acknowledging that many users of the term today have not given the semantic meaning originally associated with the word and continue to endorse its derogatory meaning. Even official race labels like the apartheid-era "black" and "coloured," as used in South Africa, have both descriptive and derogatory meanings, because, repurposing the terms of racism has not seen the power of the words diminish that much. Rather, repeating terms of racial discrimination has just added a layer of further confusion. Any reuse of a semantic term in race-thinking and racialism is not only laden with meaning, it reifies all its previous meanings. This is because, and this cannot be emphasised enough, there is no negation in the subconscious, only re-affirmation.

Besides the terms of race-hatred, even official race labels like "black" and "coloured" still used in South Africa have both descriptive and derogatory meanings, because, 
repurposing the terms has not seen their power diminish significantly (Maré, 2000, 2011). Any reuse of a race term in the service of race-thinking and racialism is not only laden with meaning, but it reinforces all its previous meanings and connotations. This greatly complicates race studies and the discussion of racethinking. Almost every effort to use race neutral terms has failed because the depauperate lexicon has already been exhausted.

It is difficult to find or create neologisms which are defined and widely understood without being descriptive or pejorative. "Gay" has served successfully for homosexual communities, and it would be ideal if a comparably upbeat and unifying term could be created or co-opted to describe former races. If one can be found that would be as successful as "gay" has been, it would be very helpful at defeating racism. Just like gay does not harp on the past discrimination, but rather promotes the group of people in uplifting terms, then any racial neologism should not be restrictive or hark back to previous slights, discrimination, and subjugation. Any effective neologism must arise from, and be acceptable to, the community to which it applies. A neologism is unlikely to be a panacea, but for it to be useful its usage cannot be restricted, limited in meaning, or confined to an inner circle supporting the Us-Them divide. Therefore, any successful neologism for defeating racism must be widely acceptable to, and universally applied within, the community that it applies to, and it must arise from within that community.

The deconstruction of race has been mostly successful in scientific circles, to the extent that it is widely accepted that the biological basis of race is without foundation, with the result that most basic biological and social scientists have rejected the concept (Graves, 2003, 2015; Soudien, 2020). This has not resulted in the abandonment of race labels in society, however. The deconstruction of race by scientists has not been accepted outside of scientific and some academic circles. Feelings and opinions about race exist in countries with past histories of legislated segregation like the United States and South Africa, even though race labels have lost all formal legitimacy (Maré, 2000). In these places, animus towards people belonging to races other than "one's own" remains and is often manifested at home or amongst others with shared attitudes, a process Maré refers to as the "privatization of race" (2000). The use of pejorative labels and epithets is illegal, but the racism persists, albeit cloaked and only privately revealed (Jablonski, 2012b). At present in the United States, the removal of some of the opprobrium towards openly racist attitudes has seen a resurgence of publicly displayed race hatred and neo-Nazi activity. This has shocked the deconstructionists of race and has shown that the imposition of science-based ideas about the biological un-reality of race is unlikely on its own to prevent racialisation, race-based derogatory discourse, and flat-out hate speech. Biological conceptions of race that linger in the popular 
imagination provide justification for a racially inequitable status quo and for continued social marginalisation of historically disadvantaged groups (Williams \& Eberhardt, 2008). The resurgence of publicly displayed race hatred is also occurring because it is seen to be tacitly authorised or condoned. Deeply held beliefs about the biological reality of race along with blatant racism previously suppressed out of fear of disapproval or legal action are now made public. This is because most people believe that race is a real biological fact.

\section{The ontological status of race as a biological fact}

The deconstruction of race has been mostly successful in science circles, to the extent that the biological basis of race is without foundation and most basic biological and social scientists have rejected the concept (Eberhardt, 2005; Eberhardt \& Randall, 1997; Relethford, 2009). The deconstruction of race by scientists has not been accepted widely outside of specific academic circles, however. The removal of some of the opprobrium towards racism in the United States under the current administration, has witnessed a resurgence of openly displayed race hatred and neo-Nazi activity. This has shocked race deconstructionists and has shown that science imposed from outside is unlikely on its own to prevent racialisation, race-based derogatory discourse, and flat-out hate speech. This is because most people believe that race is a real biological fact, and deeply held beliefs previously maintained completely in private are being aired publicly because they have been tacitly authorised. In other words, the deeply held beliefs about the biological reality of race were only suppressed out of fear of disapproval or legal action. This trend is also indicative of a deep distrust of science amongst the general public in the United States borne of the belief that science is not about the discovery of facts, but is a politicised belief system. However, the semantic intent of race as a metaphysical biological reality has been overridden by better understanding of biology and genetics (Graves, 2015; Long \& Kittles, 2009a).

If race is to stand as a biological fact, and for it to have an ontological standing as such, it should only be defined by a biological meaning. This does not stop people from adding contemporary ideas such as biogeography to make new racial terms, or to redefining and reinscribing old terms (Spencer, 2015). This has been done in reaffirming the reality of the United States Census categories according to or as coincident with reconceptions of Blumenbach's continental race groupings (Spencer, 2009). ${ }^{1}$ These reconceptions rely on ideas of within-species

1 The United States Census website states: "What is race? The Census Bureau defines race as a person's self-identification with one or more social groups. An individual can report as White, Black or African American, Asian, American Indian and Alaska Native, Native Hawaiian and Other Pacific Islander, or some other race. Survey respondents may report 
variation being developed as geographic isolates. In biological speciation theory, geographically restricted populations evolving in isolation is a major cause of subspecies arising and new species developing. That is, given some long period of isolation and further differentiation there would arise subspecies and rising eventually to the level of a separate species. Is this what is of expected of humans? Geography is not biology though. Humans have always been mobile, and few instances of true population isolation without migration or gene flow have ever been identified. Differences in skin colour are adaptions to different ecological (solar) circumstances, but these differences do not describe trophic-level sub-speciation as in ecological speciation models. Therefore, at no time has Homo sapiens been a species with separate subspecies on the way to becoming multiple new species. Despite this, the concept of population isolation is the central tenet of race purity laws. The concept fuels the propagation of beliefs about miscegenation, and of race mixing leading to genetic degradation, that are favoured by far-right and neo-Nazi groups. This is the belief that selection on human variation is eliding deleterious genes to promote a Nietzschean übermensch within one single ecological or geographic isolate. Originally, there was one pair of humans, who had evolved from other near-humans in the ancestral line. Races are never ancestral but always develop later from within-species variation working through other factors. Humans are, and have always been, a single species and they must remain so as people become ever more admixed and gene flow over long distances continues.

Species as a metaphysical reality are individuals (Ghiselin, 1997). They can be described but not defined. They are not a class or a set or a kind. Species are real individual things, but subspecies are never that. Races or biological isolates, genetic groupings, natural geographic populations, a group, a defined class, a set, are biologically subspecific entities and have no metaphysical individual reality (Ghiselin, 1997). These can be defined and are always specific to a temporally and semantically contingent usage. The United States Census categories are defined by the Bureau of the Census and their definitions changes with time and are only understood clearly by the people of the time and place where the usage is understood, even if the majority think they clearly understand the terms. Everyone who thinks of race applies a biological definition to it and, in addition, applies geographic/social/ethnic definitions used to further refine the term. Biology is always present in such conceptions because race is a quasi-taxonomic idea.

multiple races. What is ethnicity? Ethnicity determines whether a person is of Hispanic origin or not. For this reason, ethnicity is broken out in two categories, Hispanic or Latino and Not Hispanic or Latino. Hispanics may report as any race." These definitions are not exclusive and do not map easily to continents (Blumenbach, 2000; Spencer, 2009). 
No matter how we define species, as a cladistics species of common descent (Kluge \& Wolf, 1993), a biologically isolated non-interbreeding individual thing, or an idealised abstract individual thing, they all have the commonality of individuality (Ghiselin, 1997). Mere lists of characters are the phenotype, and the idea of a phenetic species definition was long abandoned as unstable and non-exclusive and not an individual. The species must be unique and is never defined by membership in a class or a set (Ghiselin, 1997). This is never true of variation within a species. A local geographic grouping of members of a species (or a deme) is always temporally contingent. Given enough time, the variant population will either merge back with the greater population it emerged from, or will become specialised or drift away from the mean so as to be no longer a variant but something definite and individual of itself. Races will disappear or become further differentiated with time. There is no realism or antirealism with respect to races, they are defined unstably to suit an end and have no enduring metaphysical standing. Any essentialism or typologies have stasis as their underlying emphasis and privilege stasis over change. Essentialism shows something to be real and immutable like a real number or pi which has essence even if not fully innumerable. In discussions of species, essentialism is often thought of as an archetype. So, if a race was an immutable Aristotelian thing, it could not be changing by definition, neither geographically or historically. We should not be able to confuse the properties and the parts of a race if they are describing a real thing. Populations are always interdependent on their members, whereas, an individual is not interdependent with another individual or with a group. The concept of a population in genetics is not as an Individual but as a class or a group and as such a population; therefore, population is never stable and is always changing the frequencies of its various genetic components. If we were to take complete genomes instead of arbitrary chosen genes, then each individual would be just an individual. If we take the complete genomes of all the variants within a species, it too would be an Individual thing encompassing all the variation but not identical to any other species. This is again not true with subspecies.

The null hypothesis for race definition, race-thinking, or racialism must be that humans are one species, not that races are real in any metaphysical sense. Before there can be race deniers, there have to be race affirmers. The affirmers of race have not yet shown race to be biologically real. The human species is an Individual and does exhibit variation and other properties, but these are temporarily contingent and open to various almost infinite definitions. These definitions are chosen for a purpose. They are said to have utility for that purpose. It is beyond metaphysics to say that the purpose is valid only whether it is not real or not. Race not being an individual thing like a species is only ontologically sound if the definition is spelled out on for each occurrence the term is invoked. This never happens. Therefore, people say they know race when they see it: race is so flexible and inclusive that 
everyone can see it how they want. When they try to put that into words, the semantic meaning of race becomes so great as to have no utility across society.

\section{Talking about race and race talk}

Should we stop talking about race? In a word, no. Denial of race will not bring about the demise of race, rather the cloaking of race will only perpetuate the power of the idea and increase its potential for harm. What we need to do is unpack the term "race" from other confusions about it. Race is not biology, linguistics, nor is it an ethnic grouping. It is not class. Race is not shorthand biology or any other grouping definition. The continued use of race serves no useful purpose. Race is not racism and the end of race classification is not the end of racism. We must recognise, though, that continued belief in real races and the biological or social reality of the race concept provide justification for a racially inequitable status quo and for continued social marginalisation of historically disadvantaged groups (Williams \& Eberhardt, 2008). We can be fairly sure that minor genetic differences that are not correlated to each other, are masked by varying amounts of admixture. Some of these are adaptive with respect to different climates and other environmental circumstances, but they cannot make people act in any particular group-correlated way. Outside of an Us-Them dichotomy, a "group-think" would never be applied. No one invokes the sinister left-handed group as a cause of crime, or that the possession of red hair has any meaning at all, even if we can define such groups with good ontological standing. Race is an historical anachronism, just like the idea of left-handedness or red-headedness being evil.

We cannot stop race talk, and in fact, it is vital we do not stop race talk. When we use it, however, we need to be very specific by what we mean by it. A neologism would help prevent racism but is fraught with difficulties of definition and acceptance. Changing language was successful in the case of gay. A more widespread and accepted redefinition of gendered speech has been a result of a change in attitude to gender equality and anti-sexism drives. A similar effort at de-gendering discourse has had less scientific study than those of biological race studies but has been widely accepted in society. The routine abandonment of the use of gendered diminutives is now widely accepted and previous usage is falling by the wayside as a result of generational change, such as female actor for actress or flight attendant for air hostess. This kind of change has yet to be seen in race discourse even though the rejection of race has a history equal in duration to the equal rights movement. Feminism as a movement, along with the rejection of homophobia and systematic discrimination in either case, is unacceptable today. This can be seen as a result of changes initiated in the social new order growing in the 1960s. These lexical success stories in sexuality and gender are not mirrored in the sphere of race, even though the civil rights movement has a slightly longer history than feminism. 


\section{Conclusion}

In speaking of race today, racial typologies should never be invoked. Race should be spoken about only in an historical context or in terms of current racism. All attempts at othering need to be resisted and any Us-Them divide removed. While many may see such changes as unrealistic or even undesirable, the abandonment of race labels freighted with historical baggage is essential. We cannot just keep the "good parts" of race, because othering has no good side. The unity of humanity is paramount. There should not be further attempts to resurrect racial thinking as a shorthand for something else. If we can unpack all confounding terms, we can show that racial thinking and, certainly, racism are never right. We can stop racism and discrimination, but not by post-racialism. Today still, racism is real even if races are not.

\section{Acknowledgements}

We are grateful to Theresa (Tess) Wilson for help with obtaining and maintaining bibliographic materials. We thank our colleague, Gerhard Maré, for valuable discussions as we developed early drafts of this chapter. We are grateful to many colleagues over the years for discussions of philosophy of taxonomy foremost amongst these being Arnold Kluge, and the California Academy of Sciences "Pizza Munch" philosophy of science forum led by Mike Ghiselin. We extend a special thank you to Mike, a man of supreme erudition, and acknowledge with gratitude his wonderful book, Metaphysics and the Origin of Species (Ghiselin, 1997). He generously donated time to explain principles of taxonomy and their implications to us. The ideas conveyed in this chapter are our responsibility alone. 


\section{References}

Bamshad, M.J.; Wooding, S.; Salisbury, B.A. \& Stephens, J.C. 2004. Deconstructing the relationship between genetics and race. Nature Reviews Genetics, 5. https://doi. org/10.1038/nrg1401

Blumenbach, J.F. 2000. On the natural variety of mankind. In: R. Bernasconi \& T.L. Lott (eds.). The Idea of Race. Indianapolis, IN: Hackett Publishing Company Inc.

Chaplin, G. 2018. An informational taxonomy of race-ideation. In: N.G. Jablonski \& G. Maré (eds.). The Effects of Race. Stellenbosch: African Sun Media.

Croom, A.M. 2011. Slurs. Language Sciences, 33(3). https://doi.org/10.1016/j. langsci.2010.11.005

Croom, A.M. 2013. How to do things with slurs: Studies in the way of derogatory words. Language \& Communication, 33(3). https://doi.org/10.1016/j. langcom.2013.03.008

Eberhardt, J.L. 2005. Imaging race. American Psychologist, 60(2). https://doi. org/10.1037/0003-066X.60.2.181

Eberhardt, J.L. \& Randall, J.L. 1997. The essential notion of race. Psychological Science, 8(3). https://doi. org/10.1111/j.1467-9280.1997.tb00412.x

El-Haj, N.A. 2007. The genetic reinscription of race. Annual Review Of Anthropology, 36(1). https://doi.org/10.1146/annurev. anthro.34.081804.120522

Ghiselin, M.T. 1997. Metaphysics and the Origin of Species. Albany, NY: State University of New York Press.

Graves Jr., J.L. 2003. The Emperor's New Clothes: Biological Theories of Race at the Millennium. New Brusnwick, NJ: Rutgers University Press.

Graves Jr., J.L. 2015. Why the nonexistence of biological races does not mean the nonexistence of racism. American Behavioral Scientist, 59(11). https://doi. org/10.1177/0002764215588810
Jablonski, N.G. 2012a. Living Color: The Biological and Social Meaning of Skin Color. Berkeley, CA: University of California Press.

Jablonski, N.G. 2012b. The struggle to overcome racism. Opinion - The Big Idea. New Scientist. 1 September. https://bit. ly/2thDcoj

Kluge, A.G. \& Wolf, A.J. 1993. Cladistics: What's in a word? Cladistics, 9(2). https://doi.org/10.1111/j.1096-0031. 1993.tb00217.x

Lee, S.S-J.; Mountain, J.L. \& Koenig, B.A. 2001. The meanings of "race" in the new genomics: Implications for health disparities research. Yale Journal of Health Policy, Law, and Ethics, 1. https://bit. ly/374Uof5

Long, J.C. \& Kittles, R.A. 2009a. Human genetic diversity and the nonexistence of biological races. Human Biology, 81(5-6). https://doi.org/10.3378/027.081.0621

Long, J.C.; Li, J. \& Healy, M.E. 2009b. Human DNA sequences: More variation and less race. American Journal of Physical Anthropology, 139(1). https://doi. org/10.1002/ajpa.21011

Maré, G. 2000. Race thinking and thinking about race: Suggestions for terminology. Research Review, 15.

Maré, G. 2011. 'Broken down by race...': Questioning social categories in redress politics. Transformation: Critical Perspectives on Southern Africa, 77. https:// doi.org/10.1353/trn.2011.0037

Relethford, J.H. 2009. Race and global patterns of phenotypic variation. American Journal of Physical Anthropology, 139(1). https:// doi.org/10.1002/ajpa.20900

Samson, J. 2005. Race and Empire. Harlow, UK: Pearson Education Limited.

Soudien, C. 2012. The modern seduction of race: Whither social constructionism? Transformation: Critical Perspectives on Southern Africa, 79. https://doi. org/10.1353/trn.2012.0022 
Soudien, C. 2020. Knowing and being: Living our learning about 'race'. In: N.G. Jablonski (ed.). Persistence of Race. Stellenbosch: African Sun Media.

Spencer, Q. 2009. Is cladistic race a genuine kind? PhD thesis. Stanford, CA: Stanford University.

Spencer, Q. 2015. Philosophy of race meets population genetics. Studies in History and Philosophy of Science Part C: Studies in History and Philosophy of Biological and Biomedical Sciences, 52(Supplement C). https://doi.org/10.1016/j.shpsc.2015.04.003

Sussman, R.W. 2014. The Myth of Race: The Troubling Persistence of an Unscientific Idea. Cambridge, MA: Harvard University Press. https://doi.org/10.4159/ harvard.9780674736160

Thompson, D. 2017. Ice Cube did everyone a favor and schooled Bill Maher on his use of the $\mathrm{N}$-word. Vibe. 10 June. https://bit. ly/2Rtz0JR
UNESCO. 1952. The Race Concept: Results of an Inquiry (The Race Question in Modern Science). Paris: UNESCO.

Wade, N. 2002. Race is seen as real guide to track roots of disease. New York Times [Online]. https://nyti.ms/2uTtU20

Watson, E.C. 2017. Sportswriter uses Notorious B.I.G. lyric containing N-word to comment on LeBron James-Knicks scuffle. Okayplayer. https://bit.ly/36445t8

Williams, M.J. \& Eberhardt, J.L. 2008. Biological conceptions of race and the motivation to cross racial boundaries. Journal of Personality and Social Psychology, 94(6). https://doi.org/10.1037/00223514.94.6.1033 

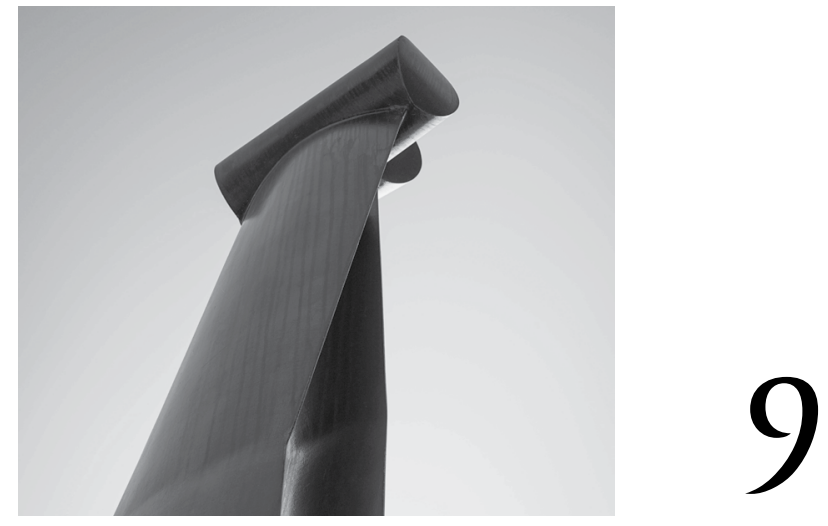

\title{
"WHO WAS HERE FIRST?", OR "WHO LIVES HERE NOW?" Indigeneity, a difference like no other
}

\author{
Zimitri Erasmus
}

On 6 February 2019, the South African parliament approved the Traditional Leadership and Khoi-San Bill B 23 D-2015 (hereinafter, "the Bill") (RSA, 2015). This comes after close to a decade of struggles, on the part of communities who selfidentify as "Khoi-San", for constitutional recognition as "traditional communities" and "indigenous people", alongside communities already recognised as such since 2003. Section 1.2 of the memorandum on the Bill states that: "While certain traditional structures and leadership positions have ... been recognised by law in compliance with the Constitutional prescripts, there has never before been statutory recognition of the Khoi-San" (emphasis added).

Approval of this Bill also comes in the wake of two reports: the first, by the United Nations (UN) Special Rapporteur, Rodolfo Stavenhagen, on the "human rights and fundamental freedoms of indigenous people" (hereinafter, "the Stavenhagen Report") (UNCHR, 2005), and the second, by the South African Human Rights Commission on the national hearing on the human rights of the Khoi-San (hereinafter, "the SAHRC Report") (SAHRC, 2018). I argue, first, 
that these documents produce "indigeneity" as a special kind of difference and present this difference as one that exceeds the banality of "race"; second, that these claims of culture encourage a politics of minorities premised on conservative multiculturalism; and third, that this politics has the potential to hinder broadbased solidarity and struggles for social justice.

\section{The Bill in brief}

Historically, the Bill must be seen against the backdrop of the Bantu Authorities Act of 1951 which initiated the apartheid state's policy of "separate development" under Prime Minister Daniel Malan, and the Promotion of Bantu Self-Government Act of 1959 passed under Prime Minister Hendrik Verwoerd. These Acts divided the majority of South Africans - classified under apartheid first as "native", then as "Bantu" and later as "black" - into separate ethnic groups "self-governed" by chiefs who were co-opted by the apartheid regime. Premised on apartheid's colonial and ethnological reasoning, these Acts racialised, ethnicised and differentiated citizenship, bound culture to custom, and fixed each to a demarcated geographical territory which it called a "homeland" or "Bantustan". These were amongst a battery of apartheid laws that wove together ideas of "race", culture, custom, nation, citizenship, territory and rights. Not all South Africans with lived experiences of blackness - the political concept that refers to people oppressed and disenfranchised under white supremacist rule - were racially classified "black" and allocated to a "homeland". Instead, those with diasporic histories of indenture and of slavery were and continue to be classified as "Indian" and "coloured" respectively. South Africans who claim "Khoi-San" identities today are historically classified as "coloured".

Contemporaneously, the Bill must be situated in relation to the South African Constitution (1996) which, considering the legacy of the 1913 Natives Land Act, provides for land restitution to individuals and communities dispossessed of land and property as a consequence of this Act. With reference to legislation passed by the post-1994 democratic government, the Bill serves to repeal three laws that recognised, provided for and regulated "traditional communities" since 2003. These include the Traditional Leadership and Governance Framework Act No. 41 of 2003, Act No. 23 of 2009, and the National House of Traditional Leaders Act No. 22 of 2009. Furthermore, the Bill must be situated in the context of failed local government, increasing inequality, contestations about the implementation of policies for redress, and the material and symbolic question of land restitution. This statutory frame mirrors the apartheid state's Bantu administration and casts social struggles into its mould. 
The Bill provides for the recognition of communities who self-identify as "traditional" and "indigenous" Khoi-San. It provides for the establishment of national, provincial, and local institutions to administer these communities and for the salaries of "traditional" and elected leaders. Chapter 4 Section 51 of the Bill makes provision for a Commission on Khoi-San Matters. Akin to bodies that produced "knowledge of the natives" to enable colonial rule, members of this Commission are required to

$[\ldots]$ have a qualification or experience in or knowledge appropriate to

(i) anthropology;

(ii) history relating to the Khoi-San;

(iii) customary law and customs and the institutions of Khoi-San leadership; or law (Section 52.1 (b) and ...

... must collectively represent a pool of knowledge concerning issues relevant to the Khoi-San groupings (Section 52.1 (c) [to fulfil its function which is] ... to investigate and make recommendations to the [relevant] Minister on the recognition of [these communities and their hereditary and elected leaders].

(RSA, 2015:Section 57.1)

The memorandum on the Bill summarises its key objectives to

- transform the traditional and Khoi-San institutions in line with constitutional imperatives such as the Bill of Rights;

- restore the integrity and legitimacy of the institutions of traditional and Khoi-San leadership in line with customary law and practices; and

- protect and promote the institutions of traditional and Khoi-San leadership.

(RSA, 2015:Memorandum, Section 1.5)

It further notes that these objectives are based on principles that "derive their mandate and primary authority from applicable customary law and customs"; promote freedom, human dignity, nation building, peace and cooperative and democratic governance with organs of state; "strive to enhance tradition and culture"; and that "advance gender equality within the institutions of the traditional and Khoi-San leadership" (RSA, 2015: Memorandum, Section 1.6).

Significantly, activists and scholars have criticised the role and relevance of a House for Traditional Leaders and of the Bill in a democratic government (see Ainslie \& Kepe, 2016; Jara \& Macingwana, 2017; Ntsebeza, 2005). They provide evidence that the jurisdictions of today's "traditional" leaders mirror apartheid's demarcation of "homelands". Drawing on the work of social scientist Mahmood Mamdani, Mazibuko Jara and Vukile Macingwana (2017) argue that the Bill entrenches a bifurcated neo-apartheid arrangement which reduces rural South Africans to "tribal subjects" and undermines struggles for the democratisation of rural governance and 
for substantive economic equality. These include struggles against the exploitation and ecological destruction of resources by global mining conglomerates; against commercial bioprospecting and for related rights to intellectual property derived from indigenous knowledge; against the tourist use-for-profit of heritage and sacred sites and artefacts; struggles for the return of human remains; and struggles against elites who benefit from business relationships between government, private companies and "traditional" leaders who enjoy locally centralised political power. It is important to note that irrespective of their cultural affiliations and of the ways in which they were classified historically, the post-1994 government has not served poor people, most of whom migrate between rural and urban areas, in ways that it could and should have.

The unintended consequence of efforts to protect the rights of "Khoi-San" communities as minorities has the potential to divide and weaken the struggles of poor people as a whole. This is evident from reported findings of a panel led by former president Kgalema Motlanthe which advocated that parliament scrap the Bill. Despite its argument that the Bill undermines the property and citizenship rights of one-third or close to 19 million of South Africa's population, parliament ignored this panel's recommendations (Kiewit, 2019).

\section{The Reports: Producing a difference like no other}

The Stavenhagen (United Nations Commission on Human Rights, 2005) and the SAHRC (South African Human Rights Commission, 2018) Reports draw on a range of reports on "indigenous peoples" produced by the UN, the International Labour Organisation and various African Commissions amongst other organisations, commissions and working groups. Of significance to this chapter are two definitions of the concept "indigenous". The Report of the African Commission's Working Group of Experts on Indigenous Populations/Communities defines "indigenous peoples" as (a) collectives of people each with an historical attachment to land, territory and a specific way of life; (b) who self-identify by specific cultural and legal practices that are discrete and distinct from dominant or mainstream social practice; and (c) whose histories and social practices render them invisible and vulnerable to discrimination (UNCHR, 2005:60-103). The Stavenhagen Report (UNCHR, 2005) draws from the International Working Group on Indigenous Populations for its operative definition of "indigenous": "non-dominant groups of aboriginal or prior descent with distinct territorial and cultural identities" (UNCHR, 2005:9, emphasis added). In South and southern Africa, the term "indigenous" has generally referred to Bantu-language-speaking communities and the legal and cultural practices associated with these. This designation was used to differentiate linguistic communities who constitute the majority in the region from 
smaller European settler communities on the one hand, and on the other hand from smaller diasporic communities considered to be "Asian", "Indian" and "coloured" (misguidedly understood to be "of mixed race").

Each of these definitions map indigenous-ness onto continuity with pre-invasion and precolonial societies to produce "indigeneity" as a static and idealised difference that is older than all other difference, uncontaminated by the politics of power, and violated historically by patterns of migration, slavery, colonialism and apartheid. The SAHRC Report mobilises the popularised notion - derived mainly from archaeology, physical anthropology and human population genetics - that the Khoi-San represent an older difference. It notes that these communities are "widely recognised as the descendants of the original Homo sapiens or "modern day man', whose ancestry can be traced back 150,000 years" (SAHRC, 2018:19). Furthermore, it points out that the San are estimated to have lived in the region for at least 120000 years and that the Khoi arrived in what we know today as the Western Cape some 2000 to 2500 years ago. The Report contrasts these long historical connections with later migrations to southern Africa from its central regions and from Europe (SAHRC, 2018:19). This Report specifically notes allegations by the Gauteng Provincial Khoi and San Council of violence against indigenous communities since the arrival of these African migrants and European settlers (SAHRC, 2018:25).

The Stavenhagen Report acknowledges that "all indigenous peoples of South Africa were oppressed and discriminated against" (UNCHR, 2005:2, emphasis added) under apartheid and that post-1994, "Blacks [continue to] constitute the poorest segment of the population, making up over 90 per cent of the 22 million poor" (2005:6). As with all black South Africans, the Report admits that what it refers to as Khoi-San "ethnic groups" - which it estimates to include 315000 to 325000 people (ibid.:7) - are internally differentiated (ibid.:9, 10) when it comes to substantive access to social services. Nevertheless, the Report maintains that these indigenous people "tend to be more marginalised" (ibid.:2) than other South Africans. It makes three significant recommendations. First, "that the legal institutions maintaining the stigma of their [the Khoi-San] classification as 'Coloureds' by the apartheid regime be removed" (ibid.:3). Second, that the South African government keeps a "national register of officially recognised indigenous communities" (ibid.:3,19). And third, that "the restitution of land claims by indigenous communities not be limited to the cut-off date of 1913" (ibid.:3). This third recommendation is not novel. It follows on a 2003 ruling of the South African Supreme Court of Appeal that communities of the Richtersveld in the Northern Cape are eligible for restitution because they were dispossessed of their land through racial discrimination prior to 1913 (Trahan, 2004). 
The first and second recommendations of the Stavenhagen Report (UNCHR, 2005) effectively amount to the reclassification of some historically classified "coloured" South Africans who self-identify as "indigenous Khoi-San". It does not contest the practice of classification per se. This is evident from the emphasis in the related SAHRC Report "that an agreed national standard for identification, verification and classification of indigenous communities in South Africa is needed" (SAHRC, 2018:54). The SAHRC Report suggests twelve groups so far. It further notes that such recognition will enable communities to "manage their own affairs" (ibid.:88). This discourse is frighteningly reminiscent of apartheid's Population Registration Act of 1950, its race classification practices, and its battery of legislation for Bantu Administration. It points to a post-1994 ethnographic state and post-1994 divide and rule. Like the Stavenhagen Report, the SAHRC Report acknowledges that "other African communities [in South Africa] may be considered to be indigenous" (ibid.:8).

Nevertheless, both Reports draw on a global discourse of "indigeneity" in an effort to construct "the Khoi-San" as especially "indigenous". The discourse of the SAHRC Report positions the Khoi-San as a "population with special needs and views" (SAHRC, 2018:10) that requires what President Jacob Zuma called a "Special Moment" for land restitution (ibid.:48) and other "special measures" (ibid.:87) for its recognition. It argues for the recognition of the Khoi-San as "the first peoples to inhabit South Africa" (ibid.:38). Moreover, the SAHRC Report positions contemporary claims to be indigenous and Khoi-San in opposition to the racial classification "coloured" during and after apartheid suggesting that today, the former confers more dignity than the banal race category. This discursive move conceives of the Khoi-San as a community distinct from "coloured" communities, as well as from what we have come to refer to as "black African" communities. In sum, both the Stavenhagen and the SAHRC Reports are premised on a discourse of conservative multiculturalism that is unlikely to contribute to cultivating a culture of social justice in this place at this time. What would it mean to see all communities with histories of conquest, slavery, indenture, and displacement as part of black experiences in South Africa?

\section{Culture and custom}

Culture has never the translucidity of custom; it abhors all simplification. In its essence it is opposed to custom, for custom is always the deterioration of culture.

(Fanon, 1990:180)

Frantz Fanon counter-poses culture with custom. Culture is understood here to be the living practices of everyday life in the present and towards possible futures. It refers to the complex ways in which we continuously forge our existence within 
historically located and always contested fields of meaning and relations. As sites of power, these fields lend themselves as much to assertions of power as to the improvisations that emerge from complex negotiations and contestations of power. Custom refers to the revival of an imagined way of life from a time long gone in an attempt to claim authenticity and belonging, and to justify rights. Custom turns culture into an unchanging set of practices that not only distinguishes but separates one group of people from another across time and space despite their historical interconnections. According to custom, culture is transmitted in almost hereditary fashion from one generation to another or ascribed according to lineage and, culture is executed repetitively according to a set of rules preserved by its custodians, usually traditional leaders. Improvisation is to culture as rigidity is to custom.

Section 5.1 (a) of South Africa’s Traditional Leadership and Khoi-San Bill recognises and provides for custom in the terms outlined above.

A community may ... apply to the Premier [of the province] concerned to be recognised as a Khoi-San community if it

(i) has a history of self-identification by members of the community concerned, as belonging to a unique community distinct from all other communities;

(ii) observes distinctive established Khoi-San customary law and customs;

(iii) is subject to a system of hereditary or elected Khoi-San leadership with structures exercising authority in terms of customary law and customs of that community;

(iv) has an existence of distinctive cultural heritage manifestations;

(v) has a proven history of existence of the community from a particular point in time up to the present; and

(vi) occupies a specific geographical area or various geographical areas together with other non-community members (all emphasis added). (RSA, 2015)

Legal scholar Yvette Trahan notes that South African jurisprudence draws this conception of custom from its adaptation and synthesis of British and Dutch colonial law. She writes that for English law "custom" has four attributes: "(1) it must be immemorial (must have been in existence from a time preceding the memory of man, a date fixed at $1189 \mathrm{AD}$ ); (2) it must be reasonable; (3) it must be certain; and (4) it must have continued as a right and without interruption since its immemorial origin" (Trahan, 2004:569). And, the same criteria apply for RomanDutch law except that the latter "only requires the custom to be an old one" (ibid.).

In contrast to this conception of culture, anthropologist Arjun Appadurai argues that, as cultural beings, humans are more than simply "bearers of history, custom, 
and habit" (Appadurai, 2013:267). People live with pasts that matter and dream of futures - though unknown and uncertain - that matter, too. What happened shapes what is possible. We should not forget to pay attention to the future. In this vein, Fanon (1986:229) writes:

There are in every part of the world men who search.

I am not a prisoner of history. I should not seek there for the meaning of my destiny.

I should constantly remind myself that the real leap consists in introducing invention into existence.

In the world through which I travel, I am endlessly creating myself.

Here, Fanon distinguishes between history as prison and invention as a route out of this prison. History refers in part to Europe's creation of race/culture/tribe as the destiny of the colonised: outside of, without, or forever trapped in history. In contrast, invention is a route out of the pre- and over-determining workings of race/ culture/tribe. This infinite and iterative process unsettles colonial conceptions of culture as static, "tribal" and racialised. Invention is both disruptive and generative. It breaks and makes. Invention undoes the existing social order. It cultivates new institutions, new practices and new ways of being for a new social order. It turns politics into a living practice for the future and accounts for the ways in which human life involves improvisation. David Marriott interprets Fanon's distinction between history and invention to suggest that "the meaning of the future cannot by definition be a simple matter of what happened in the past" (Marriot, 2012:64). Instead, this meaning is always open-ended.

\section{Recognition and social justice}

Both the Stavenhagen (UNCHR, 2005) and the SAHRC (2018) Reports construe claims in a discourse of human rights which encourages striving for the recognition of claims of culture. Such a politics of recognition produces a proliferation of difference premised on stories about the past that frame and valorise difference in terms of degrees of belonging, which translate into degrees of entitlement and legitimacy. The questions that drive these stories include: Who was here first? Who came here first? How did you come here: by foot or by boat? Rights bound to ethnology make difference absolute, endow it with intrinsic value and turn it into a currency used to bargain about belonging and entitlement. This severs difference from shared (even if differentially) institutionalised violence and inequality produced by slavery, colonialism, apartheid and their attendant forms of domination, dispossession and exploitation that continue in different ways today. Such a narrow conception of difference undermines broader struggles for social justice. 
Anthony Bogues' distinction between "political association" on the one hand and "common association" on the other hand, is valuable here. The former refers to "but one human practice among others" (Bogues, 2012:40). The latter refers to ways of life that encompass an "expanded notion of rights to include social rights" such as access to housing, health care, a living wage, and education; that practice substantive or radical equality; and that cultivate participatory forms of democracy (ibid.:40-42). On this view, "political association" can be understood as identification and "common association", as solidarity.

This returns me to Fanon who writes:

My Negro consciousness does not hold itself out as a lack. It is. (1986:135).

It was not the black world that laid down my course of conduct. My black skin is not the wrapping of specific values (1986:227).

In the first quotation above, Fanon tells us that his black consciousness is valid and has meaning because of the particular circumstances of his life: his lived experience of being black in the world. In the second, he reminds that his solidarity with the Vietnamese during the Vietnamese war was not determined by "the black world" nor was his "black skin ... the wrapping" of the political values that shaped this solidarity. This highlights the way in which the political associations we make are shaped by the ways in which we learn to make sense of ourselves and our placement in the world. At the same time, these particular political associations do not preclude broader associations.

In this vein, Kenan Malik's critique of identity politics in the United Kingdom and the United States as of the 1990s is poignant. He notes that in the 1960s identity politics was a means of challenging oppression within a broader social movement for transformation and in the face of a left politics which was blind to such oppression. As part of broader struggles against oppression, this politics of recognition did not become an end in itself. In contrast, he argues, identity politics of the late twentieth and twenty-first century has become an end in itself, deepening social divisions rather than reaching across them, and rendering collective action possible only when rooted in identity. He writes: “... the debate is not whether we should challenge oppression. It is about how we should do so” (Malik, 2017).

\section{Closure}

Similarly, I do not question the importance of re-writing the history of Southern Africa in ways that account for the presence and contributions of Khoi and San communities. Nor do I question efforts on the part of communities who identify with this history to fight against poverty and oppression. I do question the ways in which local and global legal discourse presses these social struggles into a frame 
of cultural minorities who effectively become "tribal subjects". I do question the requirement of this discourse that these so-called "minorities" be officially named and statistically counted by these names as separate collectives for their struggles to have any significance. This practice is inherently contradictory. On the one hand, it implies that you do not count as a citizen or, better still, as a resident with limited access to basic resources, unless you are classified as a member of an officially recognised cultural, ethnic or racial group. On the other hand, recognition as a member of a "traditional community", which is legally required to be represented statistically in this case, strips you of your rights as a citizen or resident. I am concerned about the implications for struggles against inequality when ethnological reasoning is used to fight for "minority rights" in South Africa today where the majority of South Africans are poor and landless. I am concerned about a politics of minorities that is framed by the questions "Who was here first?" and "Who came here first?" What would it take for South Africa to focus on who lives here now?

\section{Acknowledgements}

The completion of this work was enabled by various forms of support from Wits University: the support of the former Head of School of Social Sciences, Professor Shahid Vawda; sabbatical leave granted by the University; and financial support from the Wits University Mellon Grant for the Inclusive Professoriate. Thanks are due to Advocate Priscilla Jana, Deputy Chairperson of the South African Human Rights Commission and to the Research Advisor, Gift Kgomosotho, for inviting me to the Commission's 'Dialogue Relating to Contested "Coloured" Identities' held on 25 March 2019. This chapter is inspired by my research towards my contribution to this Dialogue. However, I respect the terms of that Dialogue as I do not refer in any way to the details of that conversation. All the documentation on which I draw are public. Special thanks also to Nina Jablonski and Dan Ncayiyana for helping me keep pen to paper. 


\section{References}

Ainslie, A. \& Kepe, T. 2016. Understanding the resurgence of traditional authorities in postapartheid South Africa. Journal of Southern African Studies, 42(1). https://doi.org/10.1 080/03057070.2016.1121714

Appadurai, A. 2013. The Future as Cultural Fact: Essays on the Global Condition. London: Verso.

Bogues, A. 2012. And what about the human? Freedom, human emancipation, and the radical imagination. Boundary 2, 39(3). https://doi.org/10.1215/019036591730608

Fanon, F. 1986. Black Skin, White Masks. London: Pluto Press.

Fanon, F.. 1990. The Wretched of the Earth. London: Penguin Books.

Jara, M. \& Macingwana, V. 2017. Bill reinforces apartheid tribal system. Mail \& Guardian [Online]. https://bit.ly/2Tz86TE

Kiewit, L. 2019. Contentious traditional leadership Bill passed. Mail \& Guardian [Online]. https://bit.ly/2TwPeVu

Malik, K. 2017. Not all politics is identity politics. Pandaemonium [Online]. https://bit.ly/361YweP [Accessed 16 October 2017].

Marriott, D. 2012. Inventions of existence: Sylvia Wynter, Frantz Fanon, sociogeny, and 'The Damned.' The New Centennial Review, 11(3). https://doi.org/10.1353/ ncr.2012.0020
Ntsebeza, L. 2005. Democracy Compromised: Chiefs and the Politics of Land in South Africa. Leiden: Brill.

RSA (Republic of South Africa). 2015. The Traditional Leadership and Khoi-San Bill, B 23 D-2015. Pretoria: Government Printing Works.

Scott, D. 2000. The re-enchantment of humanism: An interview with Sylvia Wynter. Small Axe: A Caribbean Journal of Criticism, 4(3).

SAHRC (South African Human Rights Commission). 2018. National Hearing Relating to the Human Rights Situation of the Khoi-San in South Africa. Braamfontein: South African Human Rights Commission.

Trahan, Y. 2004. The Richtersveld Community \& Others v. Alexkor Ltd: Declaration of a 'Right in Land' through a 'Customary Law Interest' sets stage for introduction of Aboriginal title into South African legal system. Tulane Journal of International and Comparative Law, 12. https://bit. $\mathrm{ly} / 2 \mathrm{FWqDBc}$

UNCHR (United Nations Commission on Human Rights). 2005. Report of the Special Rapporteur on the Situation of Human Rights and Fundamental Freedoms of Indigenous People, Rodolfo Stavenhagen. Addendum. Mission to South Africa. Report No. E/CN.4/2006/78/ Add.2. Geneva: Office of the High Commissioner for Human Rights. https://bit.ly/361abu7 

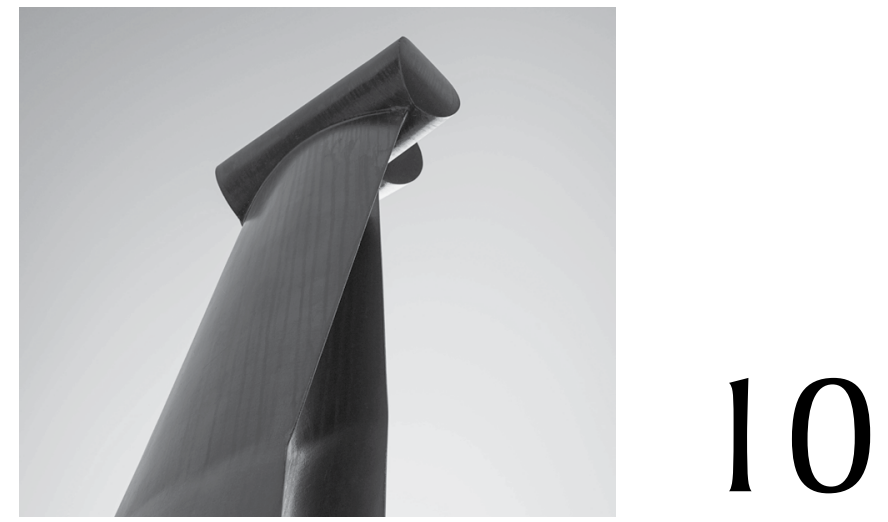

\title{
SOUTH AFRICA BEYOND "NON-RACIALISM"
}

\author{
Njabulo S. Ndebele
}

367 years ago, on 6 April 1652, a flotilla of three ships under the command of Jan van Riebeeck, landed at what would one day become the city of Cape Town. It was Van Riebeeck's second landing in Cape Town (Richards, 2018; Thom, 1952). South Africans today may not easily register the full sense of historic consequence of that landing. Over three centuries of incursion, invasion, conquest and occupation, layers of experiencing, remembering, and forgetting may have resulted in a kind of penumbra of history in which knowledge and ignorance coexisted in the half-dark and the half-light as a condition of living through imperial and colonial time. In this situation, life for the conquered nationalities of Southern Africa could be textured by anxiety, ignorance, half-knowledge, guesswork, speculation, desperate hope, and vengeful despair. Such is a state of living that conquerors impose on their subjects, and, unwittingly, on themselves! For either, though, the horizon of possibility is determined by what measure of control, or the lack of it, each has had over the course of their lives. 
There would sometimes be more darkness than light, sometimes more light, in a fraught penumbra in which both conqueror and conquered lived, more prone to be in conflict than in peace. Ultimately, over time victorious European powers succeeded in imposing a tense, ordered stability - the result of an accumulative and steadfast imposition of their power and control over Africans in Southern Africa and other parts of the Africa. The nature and state of rule that ultimately emerged in Southern Africa drew from European experience and lessons learned in South America, North America, the Caribbean, Asia and the Middle-East where non-European people were invaded, conquered, and deprived of their lands (Falola \& Roberts, 2008).

Technologically driven and therefore far more advanced than other parts of the world, the march of mercantile, and later capitalist European enterprise led to an unprecedented systemic, predatory hunger for human labour across the world, far in organisational scope than the Roman Empire and the world created by Genghis Khan (Weatherford, 2012). Europeans, increasingly under the spell of a conquering, technologically advanced culture, found it convenient to distinguish themselves from peoples they conquered on the basis skin colour, amongst other factors. That way, they could distance themselves from the common humanity they shared with those they sought to enslave. To establish themselves as a category of human above and beyond other humans, Europeans developed and fine-tuned categories of human differentiation according to what came to be known as "races." Declaratively or through implicit forms of self-legitimation, they set themselves apart at the apex of humanity as the "superior race."

In the resulting classification and hierarchical ordering of human beings and human value, the people of Africa and the Aboriginals of Australia, came to occupy the bottom rung. Other "races" in various gradations of colour and culture in Asia, North and South America got to be variously stacked up below Europeans but above Africans. Thus are Europeans to this day able to carry their imagined high "white" value wherever they are in the world; while Africans continue to be associated with low "black" value.

Those "races" located in the range between "high" and "low" could suffer various forms of affirmation or de-affirmation according to which they could feel more or less human according to the dominant European norm of "the human", depending on where they were located in the hierarchy of classification. Each could conceivably crave recognition from those "above" them; or, according to the contempt they received from "above", dispense contempt towards those "below" them. Thus did the "races" in-between implicate themselves in the formal and informal regulation of global racial hierarchy. In this manner, this classification of humans, ironically 
a part of the triumph of European modernism, and which took some five centuries to develop, became a norm in the modulation of human relationships across the globe to this day.

Over that five hundred-year time frame, in a global order supported by a mode of economic production which evolved governance and cultural institutions that justified it, the residual low "black" value of the peoples of Africa in contrast to the high "white" value of Europeans has had a resilient influence on economic and social order in countries such as Brazil, South Africa, and the United States of America where "blacks" are a statistically significant part of the national population. Perhaps South Africa is the proof of such resilience where the hegemony of racial thinking and conduct may be seen to retain currency even where "black" Africans are the overwhelming majority in a country in which they are indigenous inhabitants.

It may seem not to matter significantly that South African "blacks" have won the freedom to change their status fundamentally, both in their own country and in how they are viewed by the world beyond. Habits of discriminatory interracial behaviour cultivated and lived over five centuries of currency may prove difficult to discard even where the political conditions for changing them have been won and even established. An attitude of reflex reaction to hurt may be discerned in the very manner of self-assertion where the extent of activist anti-racist outrage may appear disproportionate to its actual cause by a white individual of ordinary pursuits, whose own "superiority" is elevated beyond its actual value and status. Such "resistance" may reinforce the sense of powerlessness even as the new sense of power is invoked. The resilience of systemic oppression tends to overwhelm resistance to it for as long its systemic authority, despite its being decried, is still embedded in the social and economic realm (Gumede, 2018).

At first emulating invader experience in other parts of the world, and then later creating a state designed purposefully around a hierarchical ordering of people according to race, the government of South Africa under Prime Minister Malan in 1948 consolidated "white" rule in the country into what came to be known as "apartheid." Later, one of the system's most renowned proponents Hendrik Verwoerd who became Prime Minster in 1958, described the system euphemistically as "separate development" (Venter \& Koers, 1999). Systematic apartheid can be seen to be the logical outcome of the British government's decision to grant dominion status to South Africa while leaving "black" South Africans to the fate of successive Afrikaner governments. In this way, Britain would maintain sovereignty over South Africa, reap attendant economic benefits while being distant from the ongoing brutal effects on Africans of its decisions (Ngcukaitobi, 2018). After the institution of slavery in the United States, the apartheid system in South Africa became the 
most driven pursuit and achievement of institutionalised racial order in the world. The system pervaded the entire country, affecting every aspect of individual and group life. It was a manner of state design and ordering that needed to be imposed by its "white" initiators and beneficiaries as much as it would be resisted by its "black" victims. Seen against this, Verwoerd's dream of a political architecture of "separate development" nursed a built-in fault line that would crack open along the path of the apartheid state's determined attempts to enforce it.

The Euro-American dominance of the world, partly through "racial" ordering, was never a one-sided drama. It was always and continues to be resisted by its "black" victims. It is ironically in this resistance that something began to happen which called into question both the colonial and imperial Euro-American ordering of the world into their racialised exploitation of it. There emerged significant moments of intercession and intersection in which solidarities of resistance between some sectors of the populations in both the colonising metropolis and its distant colonised possessions found confluence in challenging and resisting racial ordering and its deleterious effects on relations between people at both the local and global levels. The abolitionist movements in both the United Kingdom and the United States of America are cases in point (Duberman, 1935). They show that there was no unanimity in the metropolitan centres on the necessity for the institution of slavery. The abolitionist movements may have been small, but they were led by remarkable people who over time exerted considerable influence against it.

Local movements of resistance in the colonies, often gaining traction across generations of anti-colonial struggles found common cause with traditions of enlightened thinking and resistance in other parts of the world, even more particularly in the metropolitan colonial centres themselves. Such common cause was based on more than moral and ethical grounds. They also recognised connections between racial ordering in the colonies and class ordering in the European metropolis. The colonised "races" in the colonies and exploited workers in capitalist colonising Europe shared an historic interest in collaborating to counter the rising impact of capitalism in its local and global manifestations. Communist and socialist movements around the world provided organised solidarities of collaboration. The enslaved, the colonised, and workers in a global order growing in its encompassing nature, increasingly saw themselves as important cogs in the ever-intensifying global competition for material resources and human labour. They saw in this realisation points of leverage in their common struggle for human dignity (Cox, 2014).

As a consequence of its rigorous, incisive, and strong moral resonance, the Marxist critique of capitalism resonated well with colonised and working people the world over. Marxism challenged the notion of "race" by highlighting its complex 
interactions with "economic class". From the Marxist perspective, capitalism was an economic system driven by an inherently antagonistic class interests between propertied "owners of the means of production" on the one hand, and on the other, workers who sold their labour for a wage. The "owners of the means of production" and various groups of the propertied class would grow and wield enormous power over both slave and worker. Thus, a common interest between workers in the metropolitan centres of colonialism and slaves in the colonies was easy to discern, even though slaves were owned and compelled to give their labour with no monetary reward, while workers were free to sell for a wage or withhold it.

Over time, colonial capitalism built and accumulated considerable wealth and assets as it also set up global institutions governed by laws that gave formal legitimacy to its collective interests and secured its historic advantage. It was able to achieve this feat despite the statistically small number of countries that benefitted from it relative the number of countries they subjected to their control. Equally so the populations of colonised countries far outnumbered the combined populations of colonising countries. Europe, and later the United States, compensated for their small demographic size with an enormous capacity to enforce their dominance over their "possessions" with both economic and military power behind government systems they imposed with a range of legislative compulsions on colonised peoples. The fundamentals of that relationship whose evolution Vladimir Lenin pondered are still in place in much of the world today (Lenin, 1963).

Over time, economic, technological and cultural dominance created conditions in which its benefits, both individual and social, were absorbed into patterns of daily lives of people in both the dominant metropolitan countries and in their colonial "possessions". The compulsive effects of such overwhelming economic, technological dominance tend to be softer and potentially more lasting than naked projections of military power. This is despite the fact that since the 1960s and 1970s when many colonised countries won their freedom, the ability of the hegemony of dominant nations to universalise rationalisations of their dominance was considerably diminished when the power of the colonial order largely lost the appearance of permanence. The enormous inequalities in wealth running across generations both between and within countries became increasingly unsustainable on both economic and moral terms (Piketty, 2017). Climate movements around the world have come to underscore the perils that this situation poses for all peoples (Nixon, 2011).

These changes in global patterns of hegemony have important implications for what it means to be human today. Against the background of global disparities in wealth and standards of living, the voices and needs of billions of the world's once repressed people seem poised to shift more and more towards the centre of the 
world's consciousness. To be human today will be different from what it meant five hundred years ago. Invasions and conquests of old have given way to new forms of human mobility and a new global sense of right in which belonging to a country once colonised, includes an awareness of vital connection with wealthy countries in Europe implicated in the backward conditions of struggling countries. The concomitant moral rights to claim connection with Europe necessitate the search a joint search for balance between unsustainable extremes of wealth and poverty in the world. Modern human migrations, some of which have resulted in much stress in Europe, in some cases prompting new forms of nationalism and recidivist racism to reappear may be an adjustive evolutionary mechanism to achieve balance in ways that require new thinking about how people of the world should live together.

The 1960s in particular saw an historic shift in the evolution of relationships between colonising Western countries and their colonies. European countries which possessed colonies eventually yielded to irrepressible pressures from the colonies to be granted independence. The United Nations (UN) and its various agencies bound member states to the Universal Declaration of Human Rights as a context against which the rights of countries and their peoples to self-determination were universally acknowledged. European countries could not be signatories to the Universal Declaration of Human Rights and at the same time keep colonies and the inherent conditions of injustice by which those colonies were maintained. Indeed, the demand by colonised peoples engaged in various struggles for freedom had grown to irrepressible levels with mounting costs to their colonisers, making colonisation unsustainable.

In addition to economic costs, there were also profound moral costs. Against the background of two world wars in which they engaged in mutual slaughter, European countries and the United States profoundly shifted their moral sensibilities and in their different ways confronted the weight of the brutal history of their own colonisation of other countries. The reconstruction of Europe was accompanied by a greater trend towards democracy. Even in its various articulations in both capitalist and socialist governments the democratic ethos was recognised as a basis for universal participation in the governance of countries as well as in the resolution of global conflicts.

In retrospect, the era of independence for the new countries in Africa was the beginning of self-rule in which the first decade of freedom is perhaps best seen to be the first of many future transitions in the contemporary evolution of the African continent towards self-determination in whatever character that selfdetermination may take. For European countries the loss of direct control over their colonial possession would certainly have been accompanied by anxieties over their future access to mineral resources and trading markets they had access to by 
rights of dominion. Continued access would now be negotiated. But the context of such negotiation was itself fraught with contradictions. Would it be possible to achieve fair balance in mutual benefit between negotiators unevenly balanced in a global economic and geopolitical climate in which tactical and strategic benefits would highly likely accrue heavily towards stronger European and North American negotiating partners, who had established over a long period of time the rules and cultures of trade and the governance systems to manage and maintain them?

In addition to global economic and geopolitical contradictions, the character of postcolonial independence was shaped by other imponderables. There were bonds between the post-colony and departed colonisers that could not be severed overnight. Colonial languages, now the official medium of communication, together with political, economic, military, educational, judicial, religious, and cultural institutions created during colonial times had all established for newly independent countries a practical necessity for continuous engagements with former rulers. In this context, structures of postcolonial influence for Britain and France would be respectively the British Commonwealth and the French Community as structured mechanisms of influence to manage changing degrees of sovereignty and calibrate continuities and discontinuities of practice with their former colonies.

Nine years after Ghana became the first country in Africa in 1957 to gain independence from Britain Kwame Nkrumah, its first Head of State, was overthrown in a military coup. Hardly a month earlier, Nigeria's first post-independent government was overthrown in a military coup. Such dramatic seizures of state power ushered in the era of military governments in Africa. Many newly elected civilian governments were overthrown in military coups (Japhet, 2012). The causes behind this historical development are many and complex, but it could be surmised that the first wave of democratically elected governments in Africa were unable to survive internal or external pressures to deliver prosperity faster through some measure of achieved internal autonomy, or to maintain exploitative relationships with departed colonist countries.

A chief characteristic of the era of military governments was how they reproduced repressive, centralised government reminiscent of the way European colonial powers had ruled their colonies. In this way, the model of repressive colonial government was re-imposed on nominally independent states by their own elites, military or civilian. This state of affairs also allowed departed colonial countries the convenience following their departure to claim to have no formal responsibility for the emergence of totalitarian regimes in their former possessions. Britain in 1910 achieved this kind of distancing effect in South Africa through an agreement with Afrikaners to establish the Union of South Africa. Thus, Britain handed over the fate of "black" people to Afrikaners. While military governments in other African 
countries could exemplify the inability of newly freed nations to take care of themselves after having given up the saving graces of "white" colonial protection, Britain allowed racial capitalism to continue from a safe formal distance in South Africa to Britain's economic advantage. Ultimately, it will not be easy for former colonising countries to distance themselves from the full economic and moral implications of their material successes.

In many newly independent African countries, citizens found it difficult to recognise and experience the expected benefits of independence. Their independence did not lead to capable states that could ensure security of well-being for citizens in their social, economic, and political lives. Visions of freedom that once energised struggles for independence seemed to be aborted by the experience of how things seem to remain the same even as they change. Many African countries entered the competitive global arena as nominally independent countries without the wherewithal to compete meaningfully. They remained dependent in their economic and political strivings even as freedom was proclaimed by their leaders. How could colonial history be transcended by a new and equitable relations between countries worldwide? In pondering the unresolved issue of global equity, Frantz Fanon opined that the "colonised, underdeveloped man is a political creature in the most global sense of the term" (Fanon, 1963).

\section{II}

What implications would such a situation have for countries such as Brazil, South Africa and the United States (Hamilton, Huntley, Alexander, Guimarães \& James, 2001)? These countries are of some special interest for the theme of race and being human in the world. They have been the furnace in which the full impact of race in shaping global attitudes towards the experience and meaning of being human has burned furiously in the last 500 years of world history. In these three countries, the top and bottom rungs in the global hierarchy of racial order have coexisted and interacted in significant population numbers, locked to varying degrees in a fatal embrace. What lessons could they offer for the prospect of new human relations in the world?

Václav Havel speculates about the possibilities of a new world. "Above all", he writes "any existential revolution should provide hope of a moral reconstitution of society, which means a radical renewal of the relationship of human beings to what I have called the "human order" which no political order can replace. A new experience of being, a renewed rootedness in the universe, a newly grasped sense of "higher responsibility", a new-found inner relationship to other people and to the 
human community - these factors clearly indicate the direction in which we must go" (Havel, Lukes \& Keane, 1990). What would it take to achieve a world such as Havel envisaged?

The New York Times Magazine of 18 August 2019 published "The 1619 Project" (2019). It is a rigorously researched and incisive look at the legacy of slavery and how on this institution was founded the phenomenal economic prosperity of the United States. In its mechanisms, American slavery was as brutal on the slaves as it was inventive and hugely profitable for slave owners. From slave narratives and factual conditions described in "The 1691 Project", we can discern how slaves in the cotton and sugar plantations of the United States were treated as non-human objects. In their non-human state, slaves could be bought, relentlessly driven to work in cotton fields from dawn to dusk, and then sold like any other commodity. American slavery exemplifies the dehumanisation of people in which they were subjected to a system of production that became so pervasive that it shaped how "a category of persons" (Jones \& Dlamini, 2013) can be universally devalued. Against the American and global contexts of slavery, it is clear how the entire continent of Africa and its peoples became devalued in the eyes of much of the world.

Viewed gainst this historical context, a striking feature of the "The 1619 Project" is the assertion by Nicole Hannah-Jones in her essay that the American "founding ideals of liberty and equality were false when they were written. Black Americans fought to make them true. Without this struggle, America would have no democracy at all". She concludes her essay: "We were told once, by virtue of our bondage, that we could never be American. But it was by virtue of our bondage that we became the most American of all" (The 1691 Project, 2019). I understand this to mean that oppressed people in the world, by their relentless struggles to throw off the yoke of oppression in their quest for freedom and human dignity, show up to their oppressors impurities in the proclaimed civilising philosophies of goodness on the basis of which oppressors displayed their "superiority". Most of the time, from the point of view of oppressed "blacks", their "white" oppressors even as they induced fear in their victims did not appear so superior at those very moments that they displayed brutality, whether in the cotton plantations of the United States, the Jallianwala Bagh massacre of 1919 in British India, the killing fields that King Leopold of Belgium created out of the Congo (Hochchild, 2002), or in the carnage of European "world wars".

The full force of the profound change in the moral sensibilities of Europeans after the second World War emerges from their collective realisation of what two "world wars" had revealed of the state of Western civilisation. What Europeans saw of 
themselves in the mirror of history was not a pleasant reflection. This may have contributed to a leap of moral imagination to recognise the humanity of those who until then had been lowly in the European estimation of what it meant to be human in the world. Europeans became more morally mindful of how the enormous wealth they created for themselves over the centuries was implicated in their degradation of other peoples in the world. Equally so, what white Americans may see of themselves in the twenty-first century against the mirror of history reflected by "The 1691 Project" will not be pleasant to them. Instead of facing squarely the moral dilemmas posed by an economic system whose mechanisms for generating profit at the expense of African Americans were founded on the practices of slavery, white Americans evolved ingenious ways of maintaining slavery by other subtle means (Blackmon, 2008; Duvernay \& Moran, 2016). Over time, such resilient systems got embedded in political, economic, and social cultures that provide an important perspective against which to understand why white American police officers are likely to suspect unarmed "black" men as legitimate targets for what gets to be justified as legal shootings. It is as if the colour black worn by African American men, was itself a gun against which white police officers have felt by reflex a necessity to defend themselves despite the absence of an actual weapons threat against them (Tillman Jr., 2018).

From the foregoing, I seek to extrapolate the prospects for working towards Havel's world in which freedom for South African "blacks" who have liberated themselves from racial oppression do not have to bear the burden of racism in their very understanding of the nature of their freedom. Casting off this burden may be harder for African Americans in the United States where they are not the majority population. The horizons of possibility will not be the same when the oppressed are the majority population as opposed to when they are the minority.

\section{III}

Section 1 of the South African constitution sets out the values undergirding the Republic of South Africa as "one, sovereign, democratic state". The values are spelled out in subsections (a) "human dignity, the achievement of equality and the advancement of human rights and freedoms; (b) non-racialism and non-sexism; (c) Supremacy of the constitution and the rule of law; (d) Universal adult suffrage, a national common voters roll, regular elections and a multiparty system of democratic government, to ensure accountability, responsiveness and openness". I understand the order to be significant and, in all likelihood, intentional. Sections $1(\mathrm{c})$ and $1(\mathrm{~b})$ are means to achieve the values in (a) and (b). There is in this resonant, unifying statement of national values an omission that is central to the thesis of this chapter. 
What is missing in the values of the constitution is one of the most far-reaching social legacies of colonial incursion and settlement in South Africa. The discovery of diamonds and gold in the 1880s in South Africa led to one of the largest and probably the most significant subcontinental migrations in Africa. Hundreds of thousands of men across the Southern African subcontinent were forced by colonial legal compulsions to abandon their traditional agricultural economy to enter the nascent cash economy in which they had to labour for a wage and then pay tax. They were also compelled, mostly temporarily but sometimes permanently, to abandon their families. They walked or boarded trains from across South Africa, Namibia, Lesotho, Swaziland, Botswana, Mozambique, Zimbabwe, Malawi and Zambia, destined to become Africa's first working-class population in a nascent full-blown capitalist economy in Africa, centred in Johannesburg, the city of gold.

If the cotton plantations established the base of American capitalism, the mines were the base of the growth and enormous profitability of South African colonial capitalism. If, over time, millions of slaves laboured in the cotton fields of the United States and the sugar plantations in the Caribbean Islands, in South Africa millions of men across the subcontinent travelled to supply labour for the mines of South Africa under the most appalling conditions (Van Onselen, 2019). But something close to a miracle happened there in the mines and industries of Johannesburg that would to be significant enough to be considered a formative element in the quest for social cohesion in nation-building in the distant future of a South African constitutional democracy over a century later.

The value that is missing in the South African constitution was first proclaimed by several hundred of representatives of conquered peoples in Southern Africa who convened in Bloemfontein in 1912 to establish the South African Native National Convention. The educated, nascent African elites (some of them educated in the United State in the first decade of the twentieth century) and traditional leaders who included those from neighbouring countries such as Swaziland, Botswana and Lesotho, congregated in Bloemfontein after the establishment of the Union of South Africa to ponder the future of Africans in the new country from whose governance they were excluded. They founded the South African Native Congress and called for the unity of conquered and oppressed people of the South Africa to unite across tribal identities. What they envisioned was to develop on its own over nine decades of organised resistance to South African state racism. In the mines and industries of Johannesburg, tribal identities became increasingly porous as people exchanged languages, traditions, cultures, and intermarried massively over the decades. Inter-ethnic conflict in South Africa diminished significantly in scale since the 1960s in the same way that war between European countries has not occurred since the second world war. Apart from Zulu nationalism, which has been 
mobilised from time to time since the establishment of the Inkatha Freedom Party, there is has been no significant tribal mobilisation for political ends in South Africa.

Against this background, it is significant that the legacy of an historical trend towards cross-tribal cohesion has not been affirmed in Section 1(b) of the South African constitution. "Non-ethnicism" ought to have stood in the constitution along with "non-sexism" and "non-racialism" as a national value. It is significant that "white" South Africans as a group are the missing "tribe" in this Southern African evolution of non-ethnic solidarity.

This is because "whiteness" from the colonial to the apartheid state was an imposed political, economic and geographic norm, but never a demographic one (Harris, 1993). To maintain the illusion of South Africa as a "white country", the apartheid state worked hard to construct a majoritarian "whiteness" through land acquisitions that resulted in only $13 \%$ of the land declared as belonging to "black" people, and the rest of the $87 \%$ to "white" people. But it was impossible, except by genocide, to keep "black" people away from $87 \%$ "white" land. Indeed, genocide would have made no sense whatsoever because the vast sea of "black" labour was necessary to sustain South Africa's growing capitalist economy for "white" profit. Thus, through a deft political psychology, "white" South Africans sort to separate themselves from people whose predominant presence they required in other ways.

To combat racism in South Africa based on how the demographic "white" minority has "minoritised" the "black" majority, is to focus on a fundamentally false reality. This false reality diverts attention from the real objective of the "black" South African struggle for freedom. Combating "racism" only made sense as a tactic for political mobilisation. The declared primary objective has been to create a new human order in the post-1994 South African nation-state. This latter objective became difficult to discern when the tactical means to achieve it assumed the apparent status of principal cause. Minorities with power, in this case the technological dominance of Western societies, are likely to maintain dominance over numerical majorities by violent means. But the fact of such dominance being unsustainable was recognised by all the negotiating parties in South Africa who agreed on a peaceful transition to democracy in 1994. Following that the "white tribe" of South Africa was presented with an historic opportunity find a space, from which it has not been excluded, within the predominant, horizontal non-ethnic human space that has evolved for over a century of cross-ethnic interactions across the industrial landscape of South Africa. Seen against this thinking, the constitutional value of "non-racialism" is not sufficient on its own to carry the full historic significance of the non-ethnic demographic legacy. Its main weakness is to suggest that the relationship between "black" and "white", is the fulcrum around 
which hinge future human relationships in South Africa. In reality, "non-racialism" accentuates "race" even as it strives to combat it.

This situation confronts "white" South Africans with a deep existential question: where do they really belong in the world? Are they fatally attached to global whiteness in its 500-year manifestation across the world such that they would prefer to continue to be subject to the burdensome moral problematics of its history in a setting where the relevance of that history is destined to be eroded? Or, are they capable of ditching global whiteness for a new identity in community with a horizontal non-ethnic South African human reality that continues to evolve? If South Africa in 1994 significantly challenged global notions of reconciliation, would they equally challenge global notions of identity?

I would argue that the prospect of white South Africans becoming part of the demographic legacy of a horizontal community of ethnicities is far more possible in South Africa than in the United States. In the United States, the population that has historically carried the moral conscience of their country, the African Americans, may ultimately only be able to project moral idealism and legitimacy but not be able to exercise a decisive influence on the psychic and moral transformation of the Euro-American community that may have coalesced into some form of cohesion similar to South Africa's trans-ethnic cohesion but overwhelmingly dominant in projecting and maintaining the power of its collective benefits. It is precisely there that a significant difference between the South African and American trans-ethnic cohesions may be discerned. In the one case, the ethos of cohesion was based on a broad political, economic and moral consensus to tolerate the systemic oppression and exploitation of fellow citizens who were not seen as such despite being in the same country. In the case of South Africa, on the contrary, there was a "black" broad inter-ethnic consensus and commitment to combat racial oppression. The birth of the South African constitutional democracy in 1994 was an historic achievement of this consensus based on the moral idealism and political legitimacy of the majority population's commitment to achieve freedom for all South Africans in an activist constitutional democracy.

At the international level, Europe and its transatlantic component in "white" America, as well as in Australia and New Zealand face the challenge of how to live in a world shared with billions of non-Europeans who have evolved considerably over 500 years of global history and can no longer be colonised and oppressed as they used to be. They have become far more aware of their potential to reshape the world in ways that push the global environment to became more democratic and just. In 2006, Brazil, Russia, India, China and South Africa formed an association (BRICS) as major emerging economies. Between them, they account for billions of 
people who can no longer easily belong to a vertical hierarchy of human value. This development strongly suggests that the biggest global challenge of the twenty-first century will very well be the quest for a horizontal human space across the world that effectively eliminates the terrible legacy of a hierarchy of races that has bedeviled human relationships across the world for so long.

\section{IV}

The European Union (EU) has pondered for some time the notion of "a supranational democratic system" (Lamy, 2005). The idea has great merit in light of profound demographic changes in the global order. But it is an idea that can really make sense within a genuine space of equality in global discussion. A voice from the Caribbean speaks with great resonance about the global issues at stake. "The macro-reality of an ethnically non-white numerical majority being called upon to function as a cultural minority in a Eurocentric ethos laced with what has been described "the white bias" is part of the repertoire of concerns, apprehensions, resentments and frustrations of millions of Caribbean souls, from Haiti to Brazil" (Nettleford, 1993). Inward Stretch Outward Reach, the title of Nettleford's book, speaks to a necessary condition for non-Western societies to enter into new and meaningful global conversations with Western powers. Non-Western societies face the imperative of the "inward stretch" by deepening their internal economic, technological, political, and cultural capacity to negotiate "outward reach" from a position of greater strength. In this connection, the outward reach of China and India might be seen to illustrate the full potential of a visionary, resourceful, and concerted "inward stretch".

The African Union (AU), established as the Organisation of African Unity in 1963, agreed to establish the African Continental Free Trade Area after seventeen years of "difficult negotiations" (Krippahl \& Welle, 2019). It aspires towards an ambitious "Agenda 2063 for a continental market with the free movement of persons, capital, goods and services, which are crucial for deepening economic integration, and promoting agricultural development, food security, industrialisation and structural economic transformation". The success of such a continental initiative will ultimately depend on each member state of the AU "stretching inwardly". Similar regional collaborations in South America, the Middle-East, the Caribbean, and Asia express a desire for the emergence of a global order to better manage seismic changes in human global relations such as have been occurring since the end of the Second World War, in reality a European War. In light of these trends, the UN organisation in its current form seems unsuited to respond creatively to the fullest implications of unfolding global demographic shifts towards a global 
order where values of human equality, economic prosperity, and democracy are shared. In particular, the Security Council which has a strong representation of veto wielding colonial powers, is a cold war instrument that still connotes imperial hierarchies unsuited to the imperatives of horizontal interactions in the global community. It is unsuited to the evolving global times.

The appeal of democratic global institutions is that they offer the best chance for replacing legacies of race with the human pursuit of universal well-being. The challenge for bottom rung Africa will be in how the continent creates and leverages multistate capabilities founded on viable bases of internal trade within regional economic zones, as envisaged in the African continental free trade area, that cooperate with one another to harness a continental economy that can compete and collaborate with other global economies for shared benefits. Full human dignity will be better achieved and shared through collaborative human achievements based on new shared values as a foundation for a different and more human global order.

South Africans might well imagine a flotilla of three ships made in South Africa setting sail on their way to The Netherlands with a plan to dock at the port of Amsterdam meaningfully on 6 April 2022. The ships will be operated by a crew of young South African sailors under a South African commander who with his or her crew represent the country's constitutional demographic profile. Their mission will be significantly different from that of Van Reebieck who landed in Cape Town 370 years ago on that day to establish a refreshment post for the Dutch East India Company for the convenience of company ships on their way to India. Young South African passengers will disembark in Amsterdam to meet their young Dutch peers and together to explore and negotiate new relationships between The Netherlands and South Africa that will contribute towards the evolution of new moral, intellectual, political and economic global order across the entire range of human endeavour. Havel's world might suddenly look real. 


\section{References}

African Union. 2018. Agreement Establishing the African Continental Free Trade Area. https://bit.ly/361bdpZ

Blackmon, D.A. 2008. Slavery by Another Name: The Re-Enslavement of Black People in America from the Civil War to World War II. New York: Doubleday.

Cox, L. 2014. Waves of protest and revolution: Elements of a Marxist analysis. Paper presented at the Alternative Futures and Popular Protest Conference. Manchester Metropolitan University, April 14-16.

Duberman, M. (ed.). 1965. The Antislavery Vanguard: New Essays on the Abolitionists. Princeton, NJ: Princeton University Press. https://doi.org/10.1515/9781400875160

Duvernay, A. \& Moran, J. 2016. USA. Netflix.

Falola, T. \& Roberts, K.D. 2008. The Atlantic World, 1450-2000. Bloomington, IN: Indiana University Press.

Fanon, F. 1963. The Wretched of the Earth. New York: Grove Press.

Gumede, W. 2018. Institutional racism is alive and kicking in the workplace. Mail \& Guardian [Online]. https://bit. ly/3ahZEhF

Hamilton, C.V.; Huntley, L.; Alexander, N.; Guimarães, A.S. \& James, W. (eds.). 2001. Beyond Racism: Race and Inequality in Brazil, South Africa, and the United States. London: Lynne Rienner Publishers, Inc.

Harris, C.I. 1993. Whiteness as Property. Harvard Law Review, 106(4). https://doi. org/10.2307/1341787

Havel, V.; Lukes, S. \& Keane, J. 1990. The Power of Powerless. New York: M.E. Sharpe.

Hochschild, A. 2002. King Leopold's Ghost. London: Pan Books.

Japhet, M. 2012. Military coups and military regimes in Africa. Scientia Militaria - South African Journal of Military Studies, 8(4). https://doi.org/10.5787/8-4-756

Jones, M. \& Dlamini, J. 2013. Category of Persons. Johannesburg: Picador Africa.
Krippahl, C. \& Welle, D. 2019. Africa's free trade agreement: Curse or blessing? Mail \& Guardian [Online]. https://bit. ly/2R1ZFyA

Lamy, P. 2005. Towards World Democracy. London: Policy Network.

Lenin, V. 1963. Imperialism, The Highest Stage of Capitalism. Moscow: Progress Publishers.

Nettleford, R. 1993. Inward Stretch Outward Reach: A Voice from the Caribbean. London: Macmillan.

Ngcukaitobi, T. 2018. The Land is Ours. Century City, South Africa: Penguin Random House South Africa.

Nixon, R. 2011. Slow Violence and the Environmentalism of the Poor. Cambridge, MA: Harvard University Press. https://doi.org/10.4159/ harvard.9780674061194

Piketty, T. 2013. Capital in the TwentyFirst Century. Cambridge, MA: Harvard University Press. https://doi. org/10.4159/9780674369542

Richards, R. 2018. Bastards of Humans: Volume 2: 500 Years of Intimacy between South Africa and Europe. Cape Town: Indaba Publishing.

The 1619 Project. 2019. The New York Times Magazine [Online]. https://nyti.ms/ $2 \mathrm{R} 2 \mathrm{hCwW}$

Thom, H.B. (ed.). 1952. Journal of Jan van Riebeeck (Vol. I). Cape Town: A.A. Bakema.

Tillman Jr., G. 2018. The Hate U Give. 20th Century Fox.

Van Onselen, C. 2019. The Night Trains. Johannesburg: Jonathan Ball.

Venter, J.J. 1999. H.F. Verwoerd: Foundational aspects of his thought. Koers - Bulletin for Christian Scholarship, 64(4). https://doi. org/10.4102/koers.v64i4.511

Weatherford, J. 2012. Genghis Khan and the Making of the Modern World. New York: Three Rivers Press. 


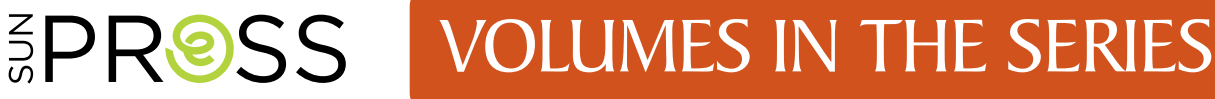
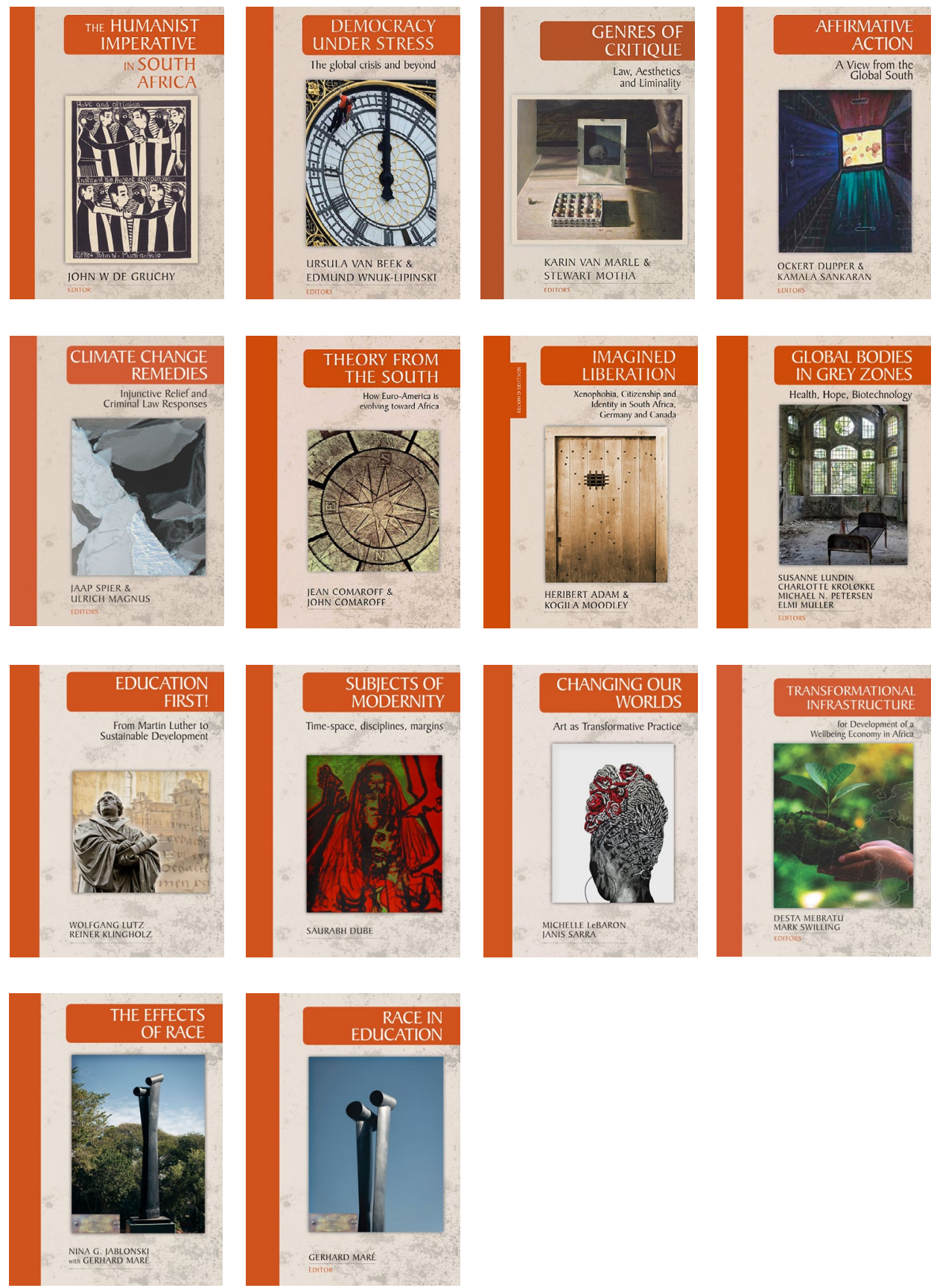